UNIVERSIDADE DE SÃO PAULO

FACULDADE DE EDUCAÇÃO

RENATA MARCÍLIO CÂNDIDO

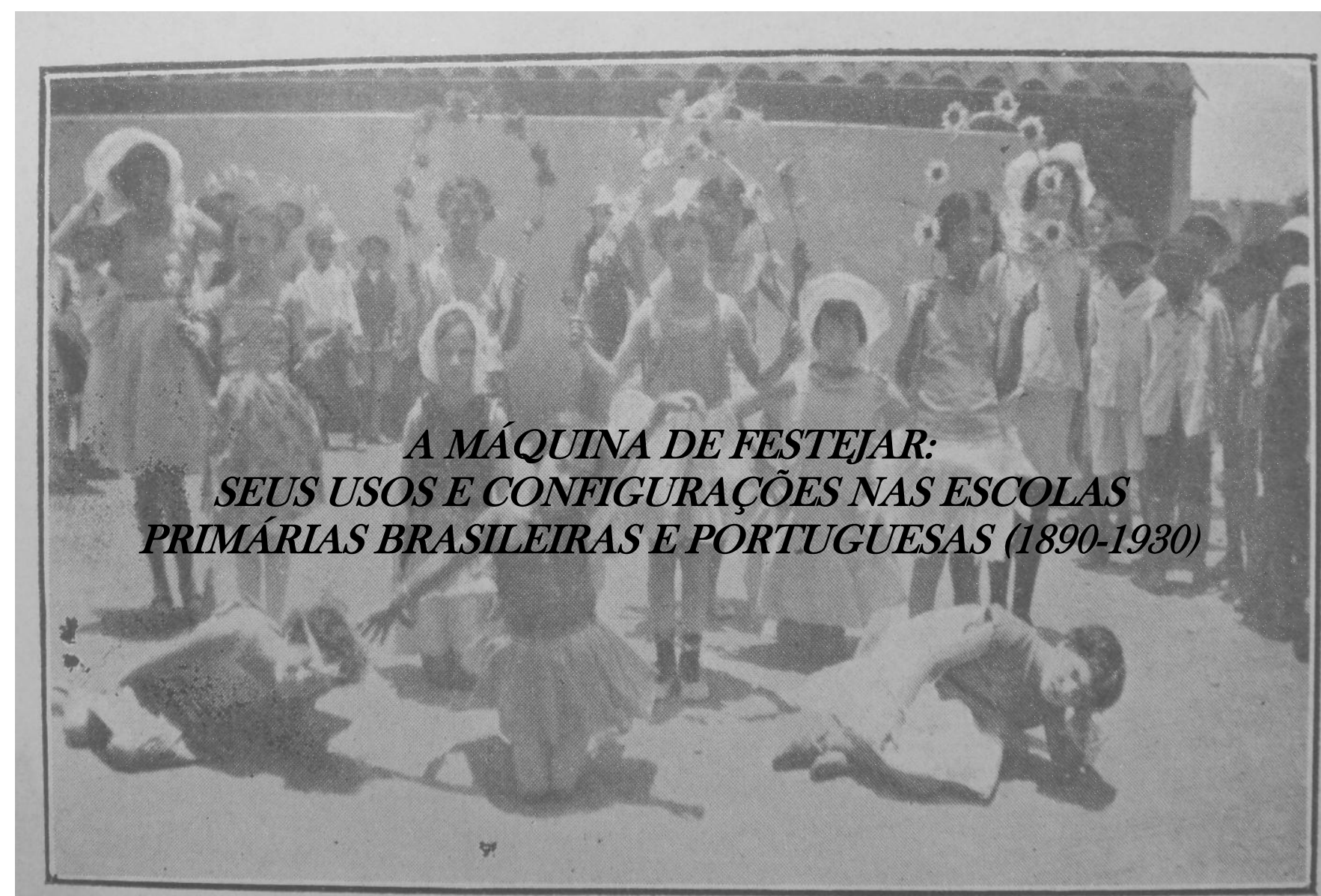

Uma das scenas da peça "FLORANEA," no Grupo Escolar de Butantan. - S. Paulo - Brasil.

SÃO PAULO

2012 
RENATA MARCÍLIO CÂNDIDO

\title{
A MÁQUINA DE FESTEJAR: \\ SEUS USOS E CONFIGURAÇÕES NAS ESCOLAS PRIMÁRIAS BRASILEIRAS E PORTUGUESAS (1890-1930)
}

\author{
Tese apresentada aO Programa de \\ PÓS-GRADUAÇÃO EM EDUCAÇÃO DA \\ Universidade de São PaUlo COMO \\ EXIGÊNCIA PARCIAL PARA OBTENÇÃO DO \\ TÍTULO DE DOUTOR. \\ ÁREA DE CONCENTRAÇÃo: HISTÓRIA E \\ HISTORIOGRAFIA DA EDUCAÇÃO. \\ OrientaÇão: Profa. Dra. Denice \\ BARBARA CATANI. \\ CoOrientaÇÃo: Prof. Dr. Jorge \\ RAMOS DO Ó. \\ VERSÃO CORRIGIDA
}


AUTORIZO A REPRODUÇÃO E DIVULGAÇÃO TOTAL OU PARCIAL DESTE TRABALHO, POR QUALQUER MEIO CONVENCIONAL OU ELETRÔNICO, PARA FINS DE ESTUDO E PESQUISA, DESDE QUE CITADA A FONTE.

Catalogação na Publicação

Serviço de Biblioteca e Documentação

Faculdade de Educação da Universidade de São Paulo

371.259 Cândido, Renata Marcílio

C217m A máquina de festejar: seus usos e configurações nas escolas primárias brasileiras e portuguesas (1890-1930) / Renata Marcílio Cândido; orientação Denice Barbara Catani; coorientação Jorge Ramos do Ó. São Paulo: s.n., 2012.

289 p.; ils.; anexos

Tese (Doutorado - Programa de Pós-Graduação em Educação. Área de Concentração: História e Historiografia da Educação) - Faculdade de Educação da Universidade de São Paulo.

1. História da educação 2. Festas (Educação) 3. Cultura escolar 4. Escola Nova 5. Escolas I. Catani, Denice Barbara, orient. II. Ó, Jorge Ramos do, coorient. 
Para minha mãe (Maria Salete Cândido), sem você nada disso seria possível! 


\section{Agradecimentos}

Fecha-se um ciclo, termina-se um percurso e já com saudades de todos que me acompanharam nesses 12 anos de estudo e pesquisa na Faculdade de Educação da Universidade de São Paulo. Como não posso e nem conseguiria agradecer literalmente todas as pessoas, relembro alguns nomes que até hoje se fazem presentes e acompanham mais de perto a minha caminhada, por vezes festiva, outras nem tanto.

Como não poderia deixar de ser, em primeiro lugar, o meu mais profundo e sincero sentimento de gratidão à minha orientadora Profa. Dra. Denice Barbara Catani, que me acolheu logo nos primeiros anos de graduação no âmbito da pesquisa de Iniciação Científica e que, desde então, tem participado do meu percurso acadêmico e profissional, Mestrado e Doutorado. A ela dedico a inspiração para a realização desta tese, ao seu profissionalismo ímpar e orientação cautelosa.

Ao Prof. Dr. Jorge Ramos do Ó, que me recebeu em terras além-mar para a realização do grande desafio da minha pesquisa acadêmica e da minha vida pessoal. Agradeço as orientações, leituras, conversas informais no bar da universidade e a possibilidade de compartilhar as minhas questões de pesquisa com outros investigadores no seu grupo de pesquisa.

A Profa. Dra. Carlota Boto, pela leitura atenta do meu exame de qualificação, às valiosas contribuições apresentadas no exame, que foram fundamentais para a estruturação da tese. Obrigada pela disponibilidade demonstrada.

A Profa. Dra. Rita de Cassia Gallego, minha amiga, cúmplice e companheira neste percurso de formação. Presente em tantos momentos importantes da minha vida acadêmica, não encontro palavras ou gestos para retribuir o carinho, apoio e as trocas possibilitadas pelos trabalhos realizados de forma conjunta.

A Profa. Dra. Paula Perin Vicentini, que desde a Iniciação Científica me acompanha, me estimula, pela amizade e pela presença, meu muito obrigado.

Ao Prof. Dr. Emerson Santana, meu primo querido e amigo de infância, hoje doutor pela Universidade de São Paulo, pela presença virtual e física constante, pela 
aposta na minha competência, pelo estímulo e conselhos fundamentais para a finalização da tese, quando tudo "parece não mais ter fimm".

A minha irmã querida, Thalita Marcílio Cândido, companheira de todas as horas, ouvinte atenta, mesmo sendo de outra área, das minhas intenções de pesquisa e do desenvolvimento do trabalho. Obrigada por existir.

Ao meu pai, Gercino Marcílio Cândido, presença inabalável em todos esses anos de formação. Sem o seu apoio e segurança nada disso seria possível.

A toda a minha família, representada pela minha "preciosa" Bia, pelos momentos de alegria, conforto e acolhimento, fundamentais para o desenvolvimento do ser humano e de qualquer pesquisa.

A Capes (Coordenação de Aperfeiçoamento de Pessoal de Nível Superior), pela concessão do auxílio financeiro para a realização do estágio de doutoramento sanduíche na Universidade de Lisboa entre os meses de março de 2010 e agosto de 2010. O período de estágio no exterior me trouxe oportunidades inestimáveis de crescimento pessoal e intelectual.

Ao meu amor, Arlindo da Silva Lourenço, pela revisão e leitura atenciosa do texto, pelos cafés, pelas conversas e incentivos, pela paciência, dedicação e amor. Bem a tempo chegaste a minha vida! É muito bom poder compartilhar a vida com você, tornando-a mais alegre e colorida. 
Lembrai-vos que em toda festa, tendes dois convivas a entreter - o corpo e a alma;

e o que dais ao corpo, na realidade o perdeis.

Mas o que dais à alma, permanece para sempre.

(Frase atribuída à Epicteto) 


\section{Resumo}

A presente tese teve como objetivo investigar, no âmbito dos estudos históricos educacionais comparados, o objeto e fenômeno "festas", realizadas no contexto escolar. A análise incidiu no período considerado de consolidação dos princípios de ensino moderno, do final do século XIX ao início do XX, em dois países cujas histórias políticas, econômicas e sociais se entrecruzaram em diferentes momentos, Brasil e Portugal. A seleção do período justificou-se pela profusão de reformas com o intuito de implementação de um sistema público, estatal, democrático e laico de ensino gestadas no decorrer do século XIX e assumidas como bandeiras dos regimes políticos republicanos. Particularmente, procurou-se compreender como as festas escolares foram forjadas nos projetos políticos e discursos educacionais do período relacionado. A retomada da metáfora da festa-máquina (OZOUF, 1976) foi particularmente fértil para a compreensão do objeto nos seus múltiplos elementos (peças), nas técnicas (engrenagens), e nos saberes e propósitos (funções). A comparação estabelecida entre a festa e a máquina suscitou inquietações a respeito de como esta maquinaria se organizou para as instituições escolares no seu propósito educativo, quais eram seus elementos, suas técnicas, suas funções e saberes. A realização das festas no âmbito escolar não se deu de forma homogênea e direta, tampouco sem equívocos e contradições. O mesmo maquinário utilizado em outros âmbitos sociais e para outros fins, precisou se adaptar ao novo contexto de idealização e concretização, além de reestruturar seus elementos e técnicas que deveriam servir, a partir de então, a um propósito eminentemente educativo. Em estudos realizados nas diferentes áreas sobre os atos festivos é recorrente a associação destes momentos a acontecimentos desregulados, alegres, sem normatização específica e cuja realização serviria à descontração do povo e à renovação das energias a partir da ruptura com o cotidiano. Contrariando tal concepção, a investigação aqui proposta demonstrou que caberiam às comemorações, assim como a todas as atividades realizadas no contexto escolar, uma função de ensino e de aprendizagem, bem como a divulgação de um saber característico da escola moderna, considerada, naquele momento, o modelo ideal de escola. Para a análise da hipótese, utilizaram-se como fontes documentais, textos publicados em periódicos de ensino brasileiros e portugueses, manuais pedagógicos e fotografias localizadas neste corpus. Os trabalhos das áreas distintas que se preocupam com a questão das comemorações e que fundamentaram teoricamente a tese apresentam-se em primeira análise, divididos entre aqueles que tomam as festas como aspecto da vida social (OzOUF, 1976; DEL PRIORE, 2000), os que as examinam em suas relações com outras dimensões da sociedade (DUVIGNOUD, 1983), aqueles que discutem mais detidamente os rituais festivos (BRANDÃO, 1978; DAMATTA, 1990), e ainda os que apresentam o funcionamento e as ressonâncias das festas nas sociedades e nos processos de formação dos sujeitos (RIBEIRO JUNIOR, 1972; AMARAL, 1998). No âmbito educacional, os conceitos de cultura escolar (JULIA, 2001; CHERVEL, 1990) e forma escolar (VINCENT, LAHIRE e THIN, 2001) subsidiaram a investigação.

Palavras-chave: História da Educação Comparada, festas sociais, festas escolares, culturas escolares, Escola Nova, escola moderna. 


\begin{abstract}
The present thesis aimed to investigate the object and phenomenon "festivals" organized inside the school context, according to the compared studies on educational history. The analysis covered the considered consolidation period of the modern education principles, from the end of the 19th century to the beginning of the $20^{\text {th }}$ century, in two countries whose political, economical and social histories are intertwined in different occasions, Brazil and Portugal. The profusion of renovations aimed to the implementation of a state, public, democratic and secular educational system during the 19th assumed as a motto of the republican political regimes was the main reason for the choice of the period. More specifically, we tried to understand how the phenomenon school festivals was inserted in the political projects and in the educational discourses from the period and transformed into expressive practices inside the public primary school contexts. The retaking of the festival-machine metaphor (OzOUF, 1976), was especially fertile for the comprehension of the object and its multiple elements (parts), techniques (gearing), and purposes (functions). The comparison established between festival and machine raises uneasiness in relation to the way the former organized itself for the educational purpose within the educational institutes, which elements, techniques, functions and knowledges were involved. The organization of festivals inside the school area happened neither in a homogeneous and direct way nor without misunderstanding and contradictions. The same machinery used in other social environments and for other purposes not only had to adapt itself to the new context of idealization and concretization, but also had to restructure its elements and techniques to a highly educational purpose from then on. In studies done on different areas about the festive events, the association of these moments with unregulated and cheerful moments without specific rules is recurrent and their organization would be for people's relaxation and energy renewal due to the routine break. Contradicting this idea, the investigation proposed herein showed that a role of teaching and learning and a disclosure of a distinguished Progressive Education knowledge, considered at that time an ideal model of school, would fit all the festivals, along with all the activities performed inside the school context. Documental sources, texts published in Brazilian and Portuguese educational journals, pedagogic handbooks and pictures located in this corpus were used to analyze this assumption. The works from distinct areas that are concerned about the celebration subject and theoretically justified the thesis presented themselves on first analysis divided among those who take festivals as aspects of social life (OzOUF, 1976; DEL PRIORE, 2000), those who analyze them in their relations with other dimensions of the society (DUVIGNOUD, 1983), those who argue more carefully the festive rites (BRANDÃO, 1978; DAMATTA, 1990), and furthermore those who present the workings and resonance of the festivals in societies and in the formation of subjects process (RIBEIRO JUNIOR, 1972; AMARAL, 1998). In the educational field, the concepts of school culture (JULIA, 2001; CHERVEL, 1990) and school form (VINCENT, LAHIRE e THIN, 2001) contributed to the investigation.
\end{abstract}

Key-words: Compared Education History, social festivals, school festivals, cultural festivals, Progressive Education, modern school. 


\section{Lista de fotografias}

1. Capa: Grupo Escolar do Butantã, São Paulo, Brasil, Revista Escolar, janeiro de 1927, p. 73.

2. Grupo Escolar de Santo André, Anuários do Ensino do Estado de S. Paulo, 1926, p. 23; p. 136.

3. Grupo Escolar de Monte Alto, São Paulo, Brasil, Anuários do Ensino do Estado de S. Paulo, 1926, p. 121; p. 136.

4. Grupo Escolar de Bica de Pedra, São Paulo, Brasil, Anuários do Ensino do Estado de S. Paulo, 1926, p. 481; p. 137.

5. Grupo Escolar de Monte Alto, Revista Escolar, abril de 1927, p. 33; p. 137.

6. Alunos da Escola Modelo Caetano de Campos e alunos dos grupos escolares da capital de São Paulo, Revista Escolar, julho, de 1927, p. 17, p. 138.

7. Escola Normal de Piracicaba - S. Paulo - Brasil, Revista Escolar, agosto de 1927, p. 81; p. 198.

8. Grupo Escolar "Conde de Parnahyba", Anuário de Ensino do Estado de São Paulo, 1926, p. 499, p. 199.

9. Escola enfeitada para a Festa da Bandeira- Grupo Escolar da Liberdade, Revista Escolar, jan 1927, p. 49, p. 223.

10. Grupo Escolar de Avaré, Revista Escolar, agosto de 1927, p. 33, p. 239. 


\section{Sumário}

INTRODUÇÃO

AS FESTAS COMO OBJETO DE ESTUDO EM PESQUISAS HISTÓRICAS E EDUCACIONAIS:

SITUANDO A NOSSA FESTA

A FESTA COMO OBJETO DA CULTURA E DE UMA FORMA ESPECÍFICA DA ESCOLA 25

FESTEJAR AQUI E LÁ: A CONSTRUÇÃO DA HISTÓRIA COMPARADA ACERCA DAS FESTAS ESCOLARES NO BRASIL E EM PoRTUGaL 29

DOS MODOS DE REALIZAR A PESQUISA ACERCA DAS FESTAS ESCOLARES

CAPÍTULO 1: DeSVELANDO AS PEÇAS DA MÁQUINA FESTIVA: UM ESTUDO GENEALÓGICO DAS COMEMORAÇÕES

CAPÍTULO 2: NO PALCO DA FESTA: AS COMEMORAÇÕES ESCOLARES NOS DISCURSOS E NAS PRÁTICAS EDUCATIVAS RENOVADAS

2.1- A EXPERIÊNCIA DA FESTA NO IDEÁRIO RENOVADO: A CENTRALIDADE DA CRIANÇA 89 2.2 - AS LIÇõES DA FESTA - A GARANTIA DO INTERESSE E O SUCESSO DO APRENDIZADO

2.3 - O TEATRO DA FESTA E O SEU APRENDIZADO SOCIAL

2.4 - OS SABERES DISCENTES NAS FESTAS - A CONSTITUIÇÃO DO HABITUS DOS ALUNOS E $O$ APRENDIZADO DO CURRÍCULO ESCOLAR

2.5 - O PAPEL DAS FESTAS NOS SISTEMAS DE ENSINO ESTATAIS: A DISCIPLINARIZAÇÃO E A MORALIZAÇÃO DA INFÂNCIA

2.6 - OS PRÊMIOS E A COROAÇÃO DOS SABERES DISCENTES

2.7 - COLOCAR A MÁQUINA EM FUNCIONAMENTO: AS ATIVIDADES DISCENTES ASSOCIADAS À REALIZAÇÃO DAS FESTAS

CAPítulo 3 : De como montar a "MÁquina" festiva: os saberes e os fazeres EDUCACIONAIS ASSOCIADOS ÀS FESTAS

3.1 - OS SABERES E FAZERES DOS PROFESSORES ASSOCIADOS ÀS COMEMORAÇõES ESCOLARES: NOS BASTIDORES DAS FESTAS

3-2 - AS FESTAS ANTIPEDAGÓGICAS: AS DISSONÂNCIAS NOS DISCURSOS DOS EDUCADORES DA ÉPOCA

CAPÍTULO 4 - A MÁQUINA FESTIVA A SERVIÇO DAS ESCOLAS BRASILEIRAS E PORTUGUESAS: OS SEUS DIFERENTES TIPOS, USOS E FUNÇÕES

4.2 - O CIVISMO COM CONTEÚDO ESCOLAR A SER ENSINADO 196

4.3 - A PERSONIFICAÇÃO DO CIVISMO E O CASO DAS HOMENAGENS 212

4.4 - A PÁTRIA REPRESENTADA POR SÍMBOLOS: AS FESTAS DA BANDEIRA 221 
4.5 - AS FESTAS BENEFICENTES: ENTRE A MORAL CRISTÃ E A ESCOLAR

4.6 - AS FESTAS DA NATUREZA: FESTA DAS AVES E DAS ÁRVORES

4.7 - CELEBRAR A ESCOLA, LEgITIMAR O ENSINO: AS FESTAS DE INAUGURAÇÃO, ANIVERSÁRIO E ENCERRAMENTO DO ANO LETIVO

CONSIDERAÇÕES FINAIS

265

REFERÊNCIAS BIBLIOGRÁFICAS

274 


\section{INTRODUÇÃO}

A festa é uma dócil maquinaria, pronta para ser montada e desmontada num abrir e fechar de olhos, tendo em vista as necessidades da causa (OzOUF, 1976, p. 224).

As festas percebidas como uma "dócil maquinaria", assim como designou Mona Ozouf (1976), entendidas nos múltiplos elementos (peças), técnicas (engrenagens), saberes e propósitos (funções) representados no seu ritual constituem-se objeto de pesquisa desta tese de doutorado. A metáfora utilizada a partir das reflexões da autora para a discussão das festas revolucionárias francesas foi extremamente relevante para a compreensão do tema no âmbito histórico educacional. A comparação estabelecida entre a festa e a máquina suscitou inquietações a respeito de como esta maquinaria se organizou para as instituições escolares no seu propósito educativo, quais eram seus elementos, suas técnicas, suas funções e saberes, ou seja, como o objeto e fenômeno festas adquiriram características pedagógicas. A realização das festas no âmbito escolar não se deu de forma homogênea e direta, sem equívocos e contradições, bem como mudanças de sentidos, mas o mesmo maquinário utilizado em outros âmbitos sociais e para outros fins precisou se adaptar ao novo contexto de idealização e concretização, reestruturar seus elementos e técnicas que deveriam servir a partir daquele momento (final do século XIX) a um propósito eminentemente educativo. Caberiam as comemorações ${ }^{1}$, assim como a todas as atividades realizadas no contexto escolar, uma função de ensino e de aprendizagem, além da divulgação de um saber característico da escola moderna, considerada, naquele momento, o modelo ideal de escola.

A presente tese se propõe a realização de uma pesquisa comparada no âmbito da história educacional brasileira e portuguesa, buscando descrever e conhecer os eventos festivos, compreender seus mecanismos de idealização e realização, os usos e representações diferenciados nas realidades dos dois países na viragem do século XIX para o XX, assim como as características que as tornaram eventos de grande atração

\footnotetext{
${ }^{1}$ As palavras festas e comemorações são utilizadas neste trabalho como sinônimas.
} 
social e potencial educativo. As questões orientadoras da pesquisa foram: como podemos definir a festa específica da escola? Quais são os elementos que as compõem e, que se repetem, permitindo percebê-las estruturalmente de forma semelhante? O que as diferenciam entre si? Qual a função pedagógica das festas escolares? E quais as suas funções sociais? Como se constituíram e se organizaram as solenidades nas escolas públicas brasileiras e portuguesas da época em questão (1890-1930)? Até que ponto as solenidades escolares são devedoras e/ou se inspiraram nas comemorações realizadas em outros âmbitos, como no religioso e o social?

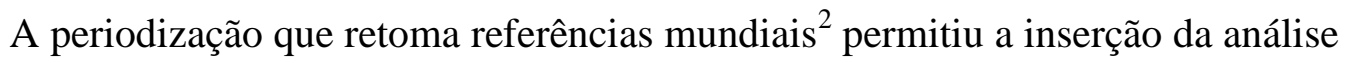
da temática em um conjunto de pesquisas levadas a efeito acerca da construção da cultura escolar relacionada aos sistemas nacionais de ensino, em outras palavras, compreender as relações estabelecidas entre a consolidação dos Estados-Nações em Portugal e Brasil e as reformulações teóricas relativas à vida escolar e às práticas de ensinar. A pesquisa tem início no ano de 1890, marco estabelecido a partir do registro da primeira notícia localizada sobre as festas no periódico educacional português $(A$ escola: revista de instrução pedagógica e de instrução pública; maio de 1890$)^{3}$ até os golpes políticos sofridos pelo Brasil e Portugal na década de 30, a partir dos quais se estabeleceram os regimes totalitários nas duas realidades. Ao se relacionarem às funções educativas e políticas em diferentes momentos das histórias dos países, não é desprovido de sentido a utilização de marcos que representaram esses dois campos para o início e término da nossa investigação - o político e o educacional. Neste sentido, o estudo conceitual, temporal e social acerca das festas praticadas nas escolas públicas desses dois países foi realizado num período considerado chave pelos teóricos da história da educação - finais do século XIX e início do XX (NAGLE, 1974; NóvOA, 1998; CATANI, 1998) cuja organização dos sistemas estatais de ensino e seus processos de elaboração foram se constituindo de forma gradativa durante todo o século XIX.

Para analisar os processos de discussões e práticas que forjaram as festas escolares nas escolas públicas primárias paulistas e portuguesas foi necessário analisar o período de constituição desse aparato de ensino, que se iniciou no século XIX e ganhou dimensões maiores no decorrer do século XX, período no qual ocorreu a institucionalização das escolas de massas em diferentes países do bloco ocidental. A

\footnotetext{
${ }^{2}$ Ou pelo menos, que dá conta das principais modificações ocorridas nos sistemas de ensino do mundo ocidental (SCHRIEWER e NóVOA, 2000).

${ }^{3}$ A primeira notícia acerca das festas escolares no contexto educacional paulista veio a público em julho de 1893 nas páginas da revista A Eschola Publica (1893-1897).
} 
ideia ao se realizar uma incursão genealógica pelo tema foi compreender a proveniência (FOUCAUlt, 2005) do objeto desta tese em um contexto de mudanças significativas para a escola. Com a nova proposta de organização do ensino de massas ou escolas graduadas, cada vez mais as comemorações escolares receberam contornos específicos, sobrepondo-se às outras realizadas em outros locais. Essas assumiram um caráter mais normatizado e marcado por regras cada vez mais detalhistas e fundamentadas nas teorias pedagógicas que se apresentaram como modernas. Entendeu-se, por isso, que a década de 1890 foi de extrema importância para a consolidação de uma série de propostas políticas renovadoras para o âmbito do ensino, sendo acompanhadas nas décadas seguintes pelos dois países investigados, por um conjunto de readequações, programas, reformas favoráveis a disseminação das escolas graduadas cuja fundamentação metodológica proposta no ideário renovado de ensino ganhou ênfase a partir da década de 20 do século XX. Almejou-se com essas escolhas cercar o período de apresentação da novidade escolar, que foram as festas e da sua consolidação como uma das possibilidades da proposta ativa de ensino. A década de 1930 foi indicada como período de término pelas reorientações políticas vivenciadas pelos dois países cujos desdobramentos puderam ser sentidos na área educacional em novas reformas da instrução e pela diminuição das notícias referentes às categorias analíticas referentes às festas construídas para essa tese.

Em estudos realizados sobre os atos festivos em áreas diversas da educacional foi recorrente a associação destes momentos a acontecimentos desregulados, alegres, sem normatização específica e cuja realização serviria somente à descontração do povo e a renovação das energias a partir da ruptura com o cotidiano. Entretanto, ao realizar leituras de textos, teses, artigos e investigações de áreas como a Sociologia, a Etnologia, a Antropologia e a História, percebeu-se que o ritual festivo poderia ter significados muito mais complexos do que a simples descontração popular. Ao falar das festas escolares almejou-se destacar, em um primeiro momento, quais foram os elementos festivos que permaneceram nestas comemorações e que remontam as solenidades realizadas por outros povos, pelas distintas religiões e pelas diferentes sociedades. Os elementos que se reproduziram independentemente do momento no qual as festas foram organizadas, permitiram que a comemoração exercesse grande influência e atração, e é justamente esta grande fascinação, a responsável pelo potencial educativo das comemorações. A instituição escolar apropriou-se (CHARTIER, 1992) do ritual festivo existente em outros âmbitos da vida social, atribuindo-o características específicas, só 
presentes nas festas dentro de seus limites, cujos objetivos deveriam ser primordialmente educativos.

A temática "comemorações escolares" foi objeto de investigação realizada por mim em estudo anterior ${ }^{4}$, o que permitiu, naquele momento para o caso brasileiro e a partir da organização e análise das informações selecionadas nos periódicos educacionais, identificar os diferentes tipos de comemorações escolares, suas funções, bem como suas formas de organização e contribuição para a disseminação de um ideal de escola e de sociedade no período compreendido entre 1890 a 1930 - Primeira República Brasileira. Nesta pesquisa o nosso olhar deteve-se no conhecimento e descrição dos eventos festivos com o intuito de compreender as suas funções sociais, políticas e educacionais. Naquele momento identificou-se a organização de solenidades para dois fins que se sobrepuseram aos demais: destacar os feitos políticos no âmbito educacional e confirmar a importância da escola entre os pais, alunos e professores para a sociedade que se organizava. Aproveitava-se do fato da população ver com "bons olhos" os acontecimentos festivos e propunha-se como um dos objetivos centrais das festas, tal como eram entendidas pelos educadores, incitar a simpatia e despertar em todas as sociedades o mais vivo entusiasmo pela educação (Revista de Ensino, junho de 1911, p. 40-41).

Não se buscava, naquele momento, analisar de forma mais detida o potencial educativo das ocasiões festivas, o que deixou em aberto a possibilidade da continuidade dos estudos a fim de responder questões associadas aos conteúdos ensinados para a população escolar e para a comunidade por meio delas, as justificativas teóricas que engendraram as suas práticas, as prescrições orientadoras dos seus saberes e fazeres, assim como o seu papel na constituição dos sistemas nacionais de ensino. A pesquisa que aqui se apresenta pretendeu detalhar a construção do objeto e fenômeno festas escolares, ampliando no espaço e nas fontes a análise da questão. No espaço, a partir da construção de uma análise histórica comparada entre Brasil e Portugal e nas fontes pela incorporação de materiais como os manuais pedagógicos.

As comemorações escolares realizadas nestes dois países, cujas histórias política, econômica e social se entrecruzaram em diferentes períodos, apresentaram características bastante similares, o que justifica a utilização do termo "festa-máquina"

\footnotetext{
${ }^{4}$ As festas escolares concebidas como elementos constitutivos e disseminadores de uma cultura escolar nas escolas públicas paulistas foram sistematizadas de acordo com tipos no período circunscrito entre 1890 e 1930 na investigação realizada em nível de Mestrado (2007) por esta pesquisadora com o título: Culturas da escola: as festas nas escolas públicas paulistas (1890-1930).
} 
como instigador de categorias de análise a serem discutidas nas duas realidades, sem, entretanto desconsiderar as suas diferenças sociais, culturais e históricas. Neste sentido, a pesquisa sobre o tema que se apresenta não poderia ter sido realizada sem uma alusão, ainda que sucinta, ao contexto político e social que as formularam, as relações entre os dois países investigados, suas fundamentações de base teórica, as possibilidades de usos que elas permitiram, suas representações e apropriações (CHARTIER, 1992).

\section{As festas como objeto de estudo em pesquisas históricas e educacionais: situando a nossa festa}

Faz-se relevante assinalar que as festas, como objeto de estudo, vêm recebendo atenção não só dos historiadores da educação, mas de outros estudiosos de outros campos de investigação, em grande parte pelo entendimento arguto que proporcionam de questões que, durante algum tempo, permaneceram à sombra das pesquisas dos campos ${ }^{5}$. O levantamento inicial de estudos sobre as festas evidenciou a recorrência de pesquisas nas diferentes áreas de conhecimento, e distintas formas de tratamento da questão. A realização desta incursão por outros campos foi extremamente fértil para cotejar conceitos e reflexões sobre o objeto de estudo, assim como possibilitar a formulação de metodologias para revelá-lo. Os trabalhos das áreas distintas que se preocuparam com o tema das comemorações apresentaram-se, em primeira análise, divididos entre aqueles que tomaram as festas como aspecto da vida social dentre outros (Ozouf, 1976; Del Priore, 2000), aqueles que as examinaram em suas relações com outras dimensões da sociedade (DUVIGNOUD, 1983) e aqueles que discutiram mais detidamente os rituais festivos (BRANDÃO, 1978; DAMATTA, 1990), e ainda outros que apresentaram o funcionamento e as ressonâncias das festas nas sociedades e nos processos de formação dos sujeitos (RIBEIRO JUNIOR, 1972; BRANDÃO, 1978; AMARAL, 1998).

Em produção recente da história da educação brasileira, o objeto "festas" adquiriu representatividade por meio da proposição de alguns estudos que as utilizaram para elucidar teses históricas diversas. Nessas, observa-se o tratamento do tema de maneira subsidiária em pesquisas que possuem outras questões como objeto; entretanto,

\footnotetext{
5 As comemorações foram objetos de estudo privilegiados em diferentes campos de investigação e puderam ser reconhecidas e legitimadas no âmbito historiográfico partir do movimento dos Annales no século XX, que buscou em um primeiro momento, uma renovação dos temas de pesquisa, para depois propor metodologias mais apropriadas à investigação dessas questões inéditas.
} 
esta constatação não diminuiu a relevância da retomada destas investigações, mesmo que de forma breve, para a compreensão das comemorações escolares como elemento pertencente a um grupo de referências de um modelo escolar. Retomando a definição da noção de contexto e seus diferentes usos, segundo Revel (1998), a contextualização dos objetos no âmbito da historiografia segue principalmente três formas: a primeira seria o uso retórico, quando o pesquisador utiliza o contexto para produzir um efeito de realidade para o seu objeto; o segundo uso constituiria o argumentativo, que é a explicação do contexto e das condições gerais nas quais uma realidade particular encontra seu lugar e, por fim, o terceiro uso, mais raro: o interpretativo, quando o pesquisador consegue extrair do contexto as razões gerais que permitiriam explicar situações particulares. A pesquisa que aqui se apresenta relacionou-se ao segundo uso proposto por Revel (1998), ao deter-se nas análises dos contextos e as condições que engendraram as solenidades nas escolas.

A legitimação do tema festas em estudos realizados nas diferentes áreas de conhecimento é devedora, segundo estudiosos do tema, da dupla instigação do folclore e da etnologia, conforme explicita Ozouf (1976) em seu texto: A festa: sob a Revolução Francesa, que retoma o objeto para explicitação de questões próprias das áreas desvelando o seu potencial analítico. De acordo com Ozouf (1976), as festas podem ser concebidas como uma máquina que, pronta para ser montada e desmontada, é capaz de servir a diferentes causas (Ozouf, 1976). No caso de suas relações com o processo revolucionário francês, assinalado por esta autora, as comemorações procuraram reviver e ensinar, pois já era conhecido pelos homens da revolução o potencial educativo deste tipo de manifestação (CONDORCET, 2008), por sua conta uma história remanipulada, reajustada, reprimida, tornando-a "uma imensa empreitada de retificação" (Ozouf, 1976, p. 230).

Ao poder público francês caberia criar novas solenidades, mas também se apropriar das comemorações já existentes para impedir que essas contrariassem seus objetivos, o que indicou uma preocupação com os usos e apropriações que se poderiam fazer dessas ocasiões. Considerando tal premissa, um estudo que pretendesse a total compreensão das festas revolucionárias não poderia ser elaborado somente com base nas idealizações dos próprios homens da revolução que as utilizaram para seu propósito, pois existiram diferenças entre a compreensão que os organizadores tiveram da festa e a dos espectadores, que se viram, muitas vezes, obrigados a decifrar apressadamente todo 
um simbolismo em movimento nas ruas francesas e que precisam ser considerados nas diversas possibilidades de apropriações dos festejos (OzOUF, 1976).

As diversidades entre as apropriações e representações das festas também são assinaladas por Mary Del Priore (2000) em seu estudo acerca das comemorações coloniais brasileiras, no qual a autora apresenta as funções oficiais e extraoficiais das mesmas, indicando o que a autora denominou de a "festa de cabeça para baixo"6. A solenidade, de acordo com Del Priore (2000), teve no período colonial brasileiro como um dos seus objetivos principais, demonstrar quem detinha o poder naquela sociedade, afirmando a perenidade das instituições dominantes (Estado e Igreja), bem como o de impor regras e normas à população brasileira. Depois de legitimadas socialmente, as festas pareceram ganhar "vida própria" adquirindo outros sentidos e funções que não os pensados originalmente.

Destes diferentes usos e apropriações percebeu-se, implicitamente, sua contribuição para o processo de constituição da identidade de uma população, conforme assinalou Roberto DaMatta (1990) em seu trabalho Carnavais, malandros e heróis: Para uma sociologia do dilema brasileiro. Nesta pesquisa, o autor procurou discutir os caminhos que tornaram a sociedade brasileira diferente e única a partir da análise crítica do mundo cotidiano, ao lado do estudo das grandes formas de congraçamento, em especial o Carnaval. Para DaMatta (1990), a festa pode ser concebida como momento em que o tempo fica suspenso, o mundo pode ser reconstruído e a liberdade de expressão do homem pode ser vivida plenamente, sendo o Carnaval uma região privilegiada para se penetrar no "coração cultural" da sociedade, na sua ideologia dominante e no seu sistema de valores. Entretanto, longe da festa ser um fenômeno de distanciamento da realidade, uma alienação, ela é uma forma de estabelecer a mediação entre a utopia e a ação transformadora, dando poder de organização aos grupos sociais (AMARAL, 1998).

Inserida em uma lógica sociocultural, a festa poderia ser um momento de expressão de carências, aspirações e disputas pelo poder, tensões que foram capazes de produzir novas sínteses de sentido e novas interpretações de símbolos já reconhecidos em festas realizadas anteriormente. Tais sínteses de sentido não são puras, mas se apresentam continuamente ameaçadas e contaminadas, e se constroem na medida em

\footnotetext{
${ }^{6}$ Uma análise antropológica das festas no período colonial pode ser encontrada em MAGALHÃES (2002). Neste estudo, a autora analisa o lugar e o significado da festa na vida social do período colonial brasileiro, comparando dois tipos de festas: a Festa do Divino e a Festa do Despotismo.
} 
que o povo reconhece e assume a contradição social. Percebe-se, neste sentido, uma incoerência nas festas populares, que ora podem legitimar a ordem dominante, ora podem promover a reorganização social a partir dos dominados (RIBEIRO JÚNIOR, 1982). Nas comemorações, de uma forma geral, a ordem vigente tanto pode ser reproduzida como invertida, dependendo do grau de poder que o povo detém em tais situações.

No âmbito educacional brasileiro, os primeiros trabalhos que mereceram ser analisados foram aqueles produzidos pelos próprios educadores da época acerca das comemorações escolares. Das primeiras décadas do século XX foram localizados alguns títulos, a saber: o trabalho de Assis Cintra, intitulado Alma Brasileira (s/d); de Carlos A. Gomes Cardim, cujo título é: As comemorações cívicas e As Festas Escolares (1916); de Francisco Oliveira Junior (s/d): Festas Escolares, e de Antonio Pedro Wolff que organizou a obra acerca das Festas escolares: coletâneas de poesias, monólogos, diálogos, hinos, etc, para as comemorações cívicas de todas as datas nacionais. Primeiro Volume: Tiradentes - 21 de abril, datada de 1918, que buscaram, além de confirmar a importância das solenidades, compilar material (poemas, hinos, peças teatrais, lições, exemplos de organizações festivas) a serem utilizados nas datas comemorativas. Esses livros apresentaram de forma bastante prescritiva o tema, indicando como deveriam acontecer as solenidades, ou seja, suas etapas, e como seus temas precisariam ser trabalhados antes e depois do evento, constituindo-se, dessa forma, material representativo do tipo de publicação, preponderantemente normativo, que circulou naquele período.

A relação entre solenidade educativa e a possibilidade de por meio delas estabelecer comparações entre os sistemas educacionais ocidentais foi estabelecida em estudo realizado por Moysés Kuhlmann Jr. (2001), no qual o autor analisa o papel atribuído ao setor educacional nas Exposições Internacionais, realizadas em diferentes países do mundo no período entre 1862 e 1922. Tais eventos constituíram-se oportunidades significativas para a proposição da educação como signo de modernidade, difundindo um conjunto de propostas nessa área, que abarcou desde materiais didáticos a métodos pedagógicos para diferentes instituições de ensino, da creche ao ensino superior. No ano de 1883, foi realizada no Brasil, uma solenidade semelhante, intitulada Exposição Pedagógica (1883), nesta ocasião as salas dos colégios particulares brasileiros apresentaram os materiais mais modernos semelhantes aos que estavam sendo utilizados nos países europeus, demonstrando sua capacidade de 
acompanhar o grande desenvolvimento que ocorria no mundo europeu e norteamericano com relação ao ensino, tanto nos aspectos materiais como nas propostas metodológicas. O Brasil se fazia representar nestas Exposições, de forma preponderante, pelos trabalhos de agulha, bordados e flores de penas, livros de ensino feitos por alunos de nossas escolas, bem como os desenhos enviados pelo Liceu de Artes e Ofícios, álbuns, manuais do Instituto dos Meninos Cegos, e a coleção fotográfica dos nossos edifícios de educação. A visibilidade permitida por estes eventos consolidou uma hierarquia entre os países considerados mais e menos desenvolvidos e modernos.

Dentre os trabalhos históricos que trataram de outras temáticas e que mencionaram exemplos de solenidades escolares de forma subsidiária destaca-se o doutorado de Rosa Fátima de Souza (1998), intitulado Templos de civilização, no qual a autora, ao tratar no âmbito dos estudos acerca da história da educação, do surgimento e consolidação dos grupos escolares ${ }^{7}$ nas primeiras décadas republicanas, desde a escolha dos locais para a construção dos edifícios, passando pelos conteúdos e metodologia utilizados nessas instituições, identificou algumas comemorações que eram realizadas naqueles estabelecimentos, especialmente as levadas a efeito por ocasião dos exames, das formaturas e das datas cívicas, com atenção para as funções que elas assumiram naquele momento importante para a constituição de um sistema estatal de ensino (SOUZA, 1998).

Outro estudo historiográfico que merece destaque foi o realizado por Rita de Cássia Gallego (2003): Uso(s) do tempo: a organização das atividades de alunos e professores nas escolas primárias paulistas (1890-1929). A pesquisa apresentada pela autora teve como objetivo investigar o processo de construção da "arquitetura temporal" das escolas públicas primárias paulistas no período de 1890 a 1929, representada por aspectos do calendário escolar como data de matrícula, início e fim das aulas, períodos de exames, horários de entradas e de saídas, feriados e festas, e por elementos que

\footnotetext{
${ }^{7}$ Os grupos escolares paulistas (escolas graduadas cujo método de ensino é o simultâneo), criados em 1893, marcaram a organização dos sistemas públicos e estatais de ensino, especialmente por estabelecerem mudanças importantes na organização administrativa e pedagógica da escola primária, dentre estas a organização das festas. Apesar dos grupos terem assumido um caráter modelar, deve-se considerar a diversidade dos estabelecimentos de ensino primário existentes, pelo menos até 1930: escolas-modelo (criadas pela reforma de 1890 para a realização da prática de ensino dos estudantes normalistas), escolas reunidas (cujo número de alunos não era suficiente para se formar um grupo escolar) e escolas isoladas (com um único professor e alunos de diferentes idades e níveis de ensino no mesmo espaço). Além dessas distinções, existem aquelas percebidas entre os estabelecimentos localizados na zona urbana e na zona rural (SOUZA, 1998; GALLEGO, 2003).
} 
ordenavam as atividades pedagógicas expressas nos quadros de horários a serem seguidos na organização das atividades dos professores e alunos: a divisão da semana e do dia de aula, as matérias e o tempo a ser dedicado ao ensino de cada uma delas, a hierarquia entre estas, o tempo de descanso (dos alunos e dos professores), a importância da pontualidade, da ordem e da disciplina, buscando apreender as permanências, rupturas e ressignificações presentes no período determinado. $\mathrm{O}$ trabalho de Gallego (2003) destaca-se pela identificação e sistematização dos festejos ocorridos nas instituições escolares como elementos constitutivos de um calendário próprio da escola.

Ainda acerca da constituição de dias comemorativos, ou dias em vermelho no calendário escolar como propôs Gallego (2003) e da sua assimilação na cultura escolar, destaca-se a tese de Paula Perin Vicentini, cuja problemática de estudo foi a recuperação das imagens e representações dos professores na história da profissão docente. A autora se propôs a analisar a imagem social do magistério no Brasil a partir dos casos do Rio de Janeiro e de São Paulo, entre os anos de 1933 e 1963 de forma articulada às representações veiculadas acerca da docência em órgãos da grande imprensa e de periódicos de entidades representativas de diferentes segmentos do professorado. No corpus documental da grande imprensa, destacou-se a data de 15 de outubro (Dia do Professor), já que se tratava de uma celebração na qual o magistério ganhava significativa visibilidade nesse tipo de mídia.

Contribuições diversas para a constituição de uma história das festas escolares puderam ser observadas no Congresso Luso-Brasileiro de História da Educação realizado entre 17 e 20 de abril 2006 em Uberlândia (Minas Gerais - Brasil). Os trabalhos que foram e continuam em desenvolvimento sobre festas escolares nos diferentes Estados brasileiros tratam de questões como o lugar ocupado pelas festas dentro das práticas educacionais constitutivas do processo de formação dos alunos, nas escolas de Belo Horizonte (Minas Gerais - Brasil); as festas no âmbito de instituições de ensino específicas no Mato Grosso do Sul no período entre 1977 e 1998 (SILVA, 2006); a relação entre o calendário das festas escolares do Lyceu Paraybano nos anos de 1913-1914 e o processo de construção da vida urbana (CARDOSO, 2006); a prática das festas cívicas da Semana da Pátria e do Dia do Trabalho durante o período estadonovista (1937-1945) em Minas Gerais (VAZ, 2006).

A apresentação de trabalhos sobre as comemorações não foi exclusiva do Congresso Luso-Brasileiro mencionado acima, mas esteve presente na realização de 
outras edições do evento, como o II Congresso Luso-Brasileiro de História da Educação, realizado em 1998, São Paulo - Brasil. Naquela oportunidade, o professor português Joaquim Pintassilgo, apresentou os resultados de sua pesquisa acerca da implementação das festas cívicas na sociedade portuguesa, intitulado Religiosidade cívica republicana - o exemplo da festa da árvore. Ainda no âmbito dos estudos históricos educacionais portugueses, destacou-se a dissertação de Mestrado de Sylvie Gonçalves Pereira: A parte recreativa da festa: o papel e funções das festas escolares no primeiro ciclo do Ensino Básico do ponto de vista pedagógico, social, moral, religioso e político na formação integral do aluno e da comunidade no Distrito de Bragança no início do século XX até a década de 1960, defendida em 2006 na Universidade de Lisboa - Portugal, na qual a autora discorreu acerca do papel e da função da festa como atividade extracurricular do ensino primário no distrito de Bragança (Portugal), durante as seis primeiras décadas do século XX. Tais pesquisas, divulgadas nos congressos da área e no âmbito das pesquisas acadêmicas, constituíramse o ponto de partida para a proposição da perspectiva comparada.

Recentemente, a Associação Nacional de História (ANPUH) publicou dois números da sua revista, Revista Brasileira de História, dedicados, um às comemorações (volume 31, número 61) e outro às festas (volume 31, número 62). No número 61, apresentou-se um conjunto de artigos que versaram na maioria dos casos, sobre comemorações relacionadas à política, aos rituais funerários e a construção das memórias coletivas de diferentes sociedades, por exemplo, textos sobre as festas da independência brasileira no contexto imperial do Rio de Janeiro - Brasil; a construção da memória da independência da Colômbia; as celebrações relativas à Revolta da Chibata (1910) no Rio de Janeiro; os rituais de comemoração no sudoeste africano como lugar de luta para a organização da memória do povo; a Revolução Constituinte em São Paulo no ano de 1932 e a invenção do culto cívico aos mortos combatentes; o processo de constituição dos funerais em liturgias cívicas; a rememoração dos estudantes mortos na resistência ao regime militar brasileiro por meio de comemorações e, as comemorações funerárias das mulheres em Atenas (séculos VI e IV A.C) a partir das epígrafes. Compondo seu conjunto de artigos, o número 62 apresenta discussões sobre: as comemorações da abolição da escravatura no Brasil; a história e a memória da Revolução Farroupilha (Rio Grande do Sul - Brasil); as comemorações da data de primeiro de maio no Estado Novo varguista; as festas cívicas nos grupos escolares do 
início do século XX em Sergipe e, a análise dos discursos de celebração da revolução de 1964 no Brasil.

A diversidade de estudos e de questões relacionadas às comemorações escolares permitiu-nos corroborar a metáfora da festa-máquina, organizada em uma série de características, de rituais e de técnicas que, muito mais do que divertimento, pode ser utilizada como momento oportuno de aprendizado de conteúdos, valores, normas e comportamentos aceitáveis socialmente, ou seja, de um determinado habitus $^{8}$ social e/ou escolar. A construção da história do objeto festa no âmbito escolar, nesta tese, pretende, assim como assinalou Foucault (2004) em sua obra A Arqueologia do Saber, compreendê-lo não somente em pensamentos, representações, imagens ou temas que permearam as fontes escolhidas para a análise, mas nos próprios discursos representativos do objeto. Cabe, neste sentido, assim como propõe Foucault (2008), mostrar em que sentido o discurso que se divulgou sobre as festas mostraram regras irredutíveis a quaisquer outras, a partir das quais se poderia ao delimitar suas "arestas" melhor conhecê-la. Para o autor, a arqueologia,

não vai em progressão lenta, do campo confuso da opinião à singularidade do sistema ou à estabilidade definitiva da ciência; não é uma 'doxologia', mas uma análise diferencial das modalidades de discurso (p. 159-160).

Concebida como um dos elementos constitutivos da cultura própria da escola, as comemorações foram organizadas por um conjunto de normas estabelecidas externamente pelos governantes que determinavam legalmente os dias a serem comemorados e um padrão de festa a ser seguido de forma a garantir o ensinamento de determinadas condutas e conhecimentos e eram também compostas por práticas coordenadas com finalidades educativas e expressivas da escola (JULIA, 2001), normas e práticas coordenadas a finalidades que poderiam variar segundo as épocas, finalidades religiosas, sociopolíticas ou simplesmente de socialização. Ao assumir tal configuração, as festas realizadas no contexto educacional adquiriram status de educativas, afinal, tudo que passasse pela escola e fosse por ela organizada não poderia deixar de ter a sua marca distintiva.

\footnotetext{
${ }^{8}$ O conceito de habitus é definido por Bourdieu (1986; 2010) como um conjunto de esquemas de percepção, pensamento e ação, capazes de orientar ou coagir práticas e representações. Para a elaboração do termo, retoma de Aristóteles a noção de hexis que foi convertida pela escolástica em habitus, cuja definição desejou por em evidência as capacidades criadoras, inventivas, ativas do habitus e do agente; o habitus indica a disposição incorporada, "quase postural", de um agente em ação (BOURDIEU, 2010, p. 61), além disso, a noção serviria para referir o funcionamento sistemático do corpo socializado (idem).
} 


\section{A festa como objeto da cultura e de uma forma específica da escola}

O conceito cultura escolar tornou-se potencialmente rico para o estudo das festas escolares ao indicar a possibilidade de investigação das instituições de ensino pela análise das representações dos conteúdos ensinados e das práticas escolares. Para Julia (2001), os conteúdos ensinados nas escolas não são nem uma vulgarização, nem uma adaptação das ciências de referência, mas um produto específico da instituição de ensino, o que denota o caráter eminentemente criativo do sistema escolar indicado, por exemplo, nas diferentes possibilidades de realização das atividades festivas de acordo com as possibilidades reais de investimento (tempo, recursos, pessoas) no desenvolvimento dos rituais escolares.

O potencial criativo da cultura escolar não tem influência somente sobre os indivíduos que freqüentam as escolas, mas também penetra, molda e modifica a cultura da sociedade global formando os indivíduos. A escola não reproduz somente os conhecimentos considerados de relevância para determinada sociedade, mas ela é criativa e (re)elabora esses conhecimentos, produzindo uma cultura específica, singular e original, cujos efeitos se estendem sobre essa mesma sociedade e sua cultura, por este motivo, o estudo que se desenvolve nesta tese, almeja relativizar o peso dos discursos oficiais sobre o tema festa e reconstruir o objeto nas suas contradições, incongruências e apropriações indicativas da própria elaboração histórica. As análises acerca das relações entre a cultura escolar e a social são discutidas também por Chervel (1990) que afirma de forma mais incisiva a originalidade do tema em questão e se interessa especialmente pela construção dos saberes escolares nas relações entre o que a sociedade deseja para a escola e o que a instituição escolar pode e faz com essas exigências, transformando-as em outras originais. Apesar das demandas de outras instituições e ordens sociais, a escola cria sua própria identidade, não sendo uma mera transposição de modelos e incorporações mecânicas de outros campos sociais, mas estabelece-se em um movimento contínuo de apropriações, reelaborações e interferências na sociedade (FARIA FILHO; VidAL et al., 2004; GALLEGO, 2008).

A cultura escolar ou culturas escolares, como desejam alguns autores (JULIA, 2001) modificam-se de acordo com os contextos históricos, o nível de instrução (ensino primário, superior, técnico), as sociedades, os projetos políticos e econômicos para a educação. O estudo destas permanências e rupturas permite compreender os princípios de engendramento e de inteligibilidade inerente a unidade da forma escolar, específica 
de uma configuração histórica particular e elaborada em determinadas formações sociais em certa época (VINCENT, LAHIRE e THIN, 2001). Concebida em um contexto específico que é a escola, a forma escolar pode também tender a estruturar outros espaços, do mesmo modo que toda relação social pode ser pedagogizada aproximando-se desse modo da formulação do conceito cultura escolar.

Vincent, Lahire e Thin (2001) assinalam que na França urbana do fim do século XVII e primeira metade do século XIX foi possível assistir a constituição de formas relativamente invariantes (isto é, recorrentes) de relações sociais: certas formas escolares de relações sociais, que se mantém, caracterizam a instituição escola e podem ser resumidas nos seguintes itens: 1) a escola como espaço específico, separado das outras práticas sociais; a existência de saberes objetivados e a escrita que permite a acumulação da cultura até então preservada no estado incorporado; 2) a escola e a pedagogização das relações sociais de aprendizagem - a constituição dos conceitos de aluno e de mestre; 3) a codificação dos saberes e das práticas que permite a sistematização do ensino por meio de rituais, símbolos, códigos; 4) "a escola - como instituição na qual se fazem presentes formas de relações sociais baseadas em um enorme trabalho de objetivação e de codificação - é o lugar da aprendizagem de formas de exercício do poder" e 5) o predomínio da língua escrita e sua necessidade para o domínio do saber escolar. A indicação desses itens permitiu conhecer uma forma escolar que se pretendeu hegemônica para vários países do mundo ocidental.

Os conceitos de forma e cultura escolar são relevantes não só para a compreensão das características internas às escolas, mas também para a análise das reformas educativas que determinaram mudanças estruturais mais abrangentes para todo um sistema de ensino. Conforme explica Vinão Frago (1996), os reformadores da educação e do currículo possuem a crença messiânica de que é possível uma ruptura completa entre o passado e as novas propostas curriculares ou as reformas educativas. Entretanto, aqueles que tem se dedicado ao estudo das reformas educativas (de organização escolar, currículo) constatam, algumas vezes, o relativo fracasso das mesmas. Esta constatação tem levado à defesa, em alguns casos, das mudanças sem reformas ao invés das reformas sem mudanças, e em outros casos a proposta de estudo da escola como centro de mudança. Em outras palavras, o fracasso de algumas reformas educativas pode ser compreendido pela resistência à mudança presente em uma cultura escolar perpetuada. Para entender porque algumas reformas não conseguem se estabelecer é preciso, segundo o autor, em um primeiro momento, conhecer e analisar a 
cultura escolar antes de qualquer mudança ou inovação, percebendo a diferença existente entre as mentalidades ou as culturas próprias dos gestores, supervisores e reformadores e a dos professores, para que dessa forma, seja possível, recriar uma nova cultura escolar dos professores, que modifiquem algumas das características de sua mentalidade e dos modos de fazer tradicionais. O termo cultura escolar, de significado ambíguo e polissêmico, segundo Viñao Frago:

compreende, en su perspectiva histórica, un conjunto de modos de hacer y pensar de creencias y praticas, de mentalidades y comportamientos sedimentados a lo largo del tiempo y compartidos en el seno de las instituciones educativas, que se transmitem a los nuevos miembros de la comunidade escolar, en especial a los profesores y a los alumnos, y que proporcionan estrategias para integrarse en las mismas, interactuar y llevar a cabo sobre todo en el aula, las tareas cotidianas que de cada uno se esperan, así como, al mismo tiempo, para hacer frente a las exigências y limitaciones que implican o conllevan (VIÑAO FRAGO, 1996, p.23).

A apropriação do termo cultura escolar no contexto educacional brasileiro ganhou destaque nas discussões educacionais a partir da década de 1970 no centro dos debates sobre a crise educacional. O artigo de José Mario Pires Azanha (1990-1991), intitulado Cultura escolar brasileira: um programa de pesquisa destaca-se ao propor um estudo da chamada crise educacional a partir de um inventário das práticas escolares, de maneira a realizar um mapeamento cultural da escola, atento à sua constituição histórico-social. Para Azanha (1990-1991), assim como propõe Viñao Frago (1996), faz-se relevante descrever as "práticas escolares" e seus correlatos: mentalidades, conflitos, hábitos, procedimentos, regulamentações, pois somente o acúmulo dessas análises permitirá compor um quadro compreensível e abrangente da situação escolar, para depois podermos explicá-la e reformulá-la. Azanha (1990-1991) argumenta que é inviável compreender a crise da escola pelos seus "resultados objetivos" sem um esforço preliminar de compreensão da cultura histórica escolar. E esse esforço só é possível através de um amplo conjunto de investigações ("multi e interdisciplinares") capazes de analisar as manifestações culturais que acontecem no ambiente escolar e que se objetivam em determinadas práticas. Somente desse modo podemos chegar a hipóteses significativas sobre a crise educacional na sua dimensão histórico-social.

O estudo da festa como elemento constitutivo de uma cultura e de uma forma escolar específica permite a compreensão de questões que ultrapassam a sua idealização e concretização, por meio da análise das normas e das práticas festivas (JULIA, 2001) é 
possível compreender um conjunto de modos de fazer e de pensar a escola, suas formas de conceber o ensino e a educação, os comportamentos escolares e sociais desejados para uma determinada comunidade, os valores compartilhados, as metodologias de ensino, os conteúdos ensinados e as estratégias criativas que a escola utiliza para a transformação das demandas sociais em um projeto próprio (CHERVEL, 1990; VINÃO FRAGO, 1996). A escola forma a festa e é formada por ela; as ocasiões festivas, ao serem apropriadas pelas instituições de ensino, ganharam contornos particulares capazes de indicar em "grande estilo", o festivo, o lugar social ocupado pela escola e seus ensinamentos. Ela faz parte de uma definição de cultura escolar que ultrapassa o sistema de ensino, de acordo com Perrenoud (1995) e pode ser analisada a partir da cultura a ensinar, ou seja, dos conteúdos previstos no currículo oficial e da cultura da organização, determinando ciclos, tarefas e conhecimentos que ultrapassam a formalidade do ensino. Neste sentido, conforme nos lembra Perrenoud (1995) a cultura escolar não designa somente as pessoas da escola, mas os saberes e o saber-fazer, hábitos e atitudes que não pertencem propriamente a escola ou as pessoas da escola, sendo assim, a definição de cultura escolar ultrapassa o sistema de ensino e pode ser dividida em duas: a cultura a ensinar e a cultura da organização.

Além de serem constitutivas de uma cultura própria da escola, as festas escolares, retomando a definição de Buisson (1878-1887) ${ }^{9}$, são aquelas que acontecem nas instituições de ensino dos diferentes níveis e para os alunos, por um ritual distinto associado a propósitos pedagógicos levado a efeito pelos alunos e professores. Aos propósitos educativos poderiam ser associados outros com funções políticas, religiosas e morais, indicativos das variadas utilidades $\mathrm{e}$ vantagens das festas para $\mathrm{o}$ desenvolvimento integral da criança, bem como para a divulgação de saberes para a sociedade.

\footnotetext{
${ }^{9}$ Em verbete do Dictionnaire de pédagogique et d'instruction primaire, organizado por Ferdinand Buisson com primeira edição publicada em 1874, ainda existe a associação do conceito festa às homenagens organizadas pelos alunos aos seus professores, a realização de comemorações religiosas que não teriam mais razão de existir nas escolas laicas e ainda, sobre o potencial pedagógico das cerimônias "especiais e solenes" para entrega de prêmios aos melhores alunos, consideradas pelo autor como o objetivo final da emulação.
} 


\section{Festejar aqui e lá: a construção da história comparada acerca das festas escolares no Brasil e em Portugal}

Festejar é repetir que o presente não é um desvio de rumo e que o futuro está aberto à eternidade (SINGER, 1986, p. 33).

A construção da história da educação comparada apresenta-se sempre como um grande desafio ao trabalho do pesquisador, sempre se conhece uma realidade melhor do que a outra, e este é um dos limites reconhecidos deste tipo de pesquisa. Ao selecionar dois países, um período e um tema, corre-se os riscos de aproximar-se mais de uma realidade do que de outra. Por outro lado, este tipo de investigação tem se mostrado potencialmente rico para o tratamento de questões e objetos comuns a duas realidades sociais e históricas distintas, permitindo uma compreensão mais acentuada de questões tratadas inicialmente de forma mais demorada nos diferentes âmbitos nacionais. Antes de elaborarmos a análise comparativa da história da festa, faz-se necessário refletir sobre como se foi construindo o quadro de referências comuns que possibilitou a comparação entre os dois países, com a finalidade de compreender melhor o objeto escolhido para a análise e as suas funções nas diferentes realidades educacionais dos países investigados.

A prática da comparação em escritos literários, acadêmicos, econômicos e políticos, esteve presente na história da humanidade desde tempos remotos; o ato de conhecer uma outra realidade era acompanhado do seu respectivo registro escrito como forma de marcar essa nova descoberta, bem como para poder compará-la com uma outra realidade já conhecida. Afirma-se, desse modo, que a história começou como um relato, "a narração daquele que pode dizer "Eu vi, senti"'; e este aspecto da história-relato, da história-testemunho, apesar de criticado por alguns estudiosos, "jamais deixou de estar presente no desenvolvimento da ciência histórica" (LE GoFF, 1990, p. 09).

No contexto mundial escolhido para o início da pesquisa (século XIX), a elaboração de estudos comparativos entre as nações ganhou novos contornos como formas de diferenciação, de criação de categorias comparativas e elaboração de rankings entre os países, justificando determinadas práticas e idéias acerca dos países "superiores e inferiores" (mais modernos/menos modernos; mais desenvolvidos/menos desenvolvidos) na elaboração de um "pretenso" ranking das nações. Tratava-se de uma comparação realizada com critérios ainda pouco refinados, segundo alguns estudiosos, de forma quase intuitiva, atendo-se mais às questões geográficas, políticas e econômicas 
e reduzindo-se à escrita e à análise de temas em função de modelos preconcebidos. Privilegiaram-se as explicações globais e totalizantes do planeta, deixando de lado a complexidade deste, como da vida social:

(...) operaban soslayando lo impensable desde sus propias perspectivas, ordenando, clasificando y controlando a partir de categorias que impedían dar cuenta de fenómenos fuera de su alcance (GVRITZ, 2001, p. 22).

No campo científico, em finais do século XIX, identificou-se um movimento que deu um novo fôlego à ideia do comparativismo, contribuindo de forma indelével para a sua legitimidade no âmbito internacional; buscava-se uma ciência internacional em projetos de intelectuais de diversas partes do mundo (WAGNER, P; 2006, p. 16) ${ }^{10}$. Neste contexto, dois conceitos-chave foram elaborados para dar conta das questões epistemológicas comparativas que surgiam: o conceito de internacionalização, que se refere a uma questão sócio-histórica relativa à extensão de uma forma específica dada ao conhecimento através do espaço, como por exemplo, o território de um país, e a universalização entendida como a legitimidade dada a um determinado conhecimento independente do tempo e do espaço, ou seja, as temáticas que poderiam ser tratadas mundialmente. Supõe-se, nesta proposta, as constantes interações entre os âmbitos macro e o micro para a análise das temáticas mundiais, ou seja, como elas foram elaboradas e divulgadas nos campos científicos, primeiro no contexto dos países e depois em âmbito internacional. Os dois conceitos se relacionam e precisam ser analisados nos seus matizes, seus objetivos e projetos específicos dentro de um contexto social e histórico (CHARLE, C.; SCHRIEWER, J. e WAGNER, P; 2006).

A mudança de escala aparece na definição da micro-história como forma de apreensão de novos sentidos para os objetos. Segundo Revel (1998), o problema colocado é o da representatividade de cada amostra em relação ao conjunto no qual ela se integra, "assim como uma peça deve encontrar seu lugar num puzzle" (REVEL, 1998, p.20) e dos efeitos de conhecimento associado ou esperado da passagem da escala micro-macro-micro, bem como os seus limites. Sendo assim, vale destacar que não podemos somente explicar o macro pela utilização de um conjunto de estudos micros, tampouco utilizar a perspectiva micro para conhecer as macro-histórias. Neste caso,

\footnotetext{
10 Relatórios como "Educação no Estrangeiro", "Educação Internacional". "Educação comparada", "Investigação sobre Políticas Educativas", "Economia da Educação" e "Planejamento da Educação", orientados para o desenvolvimento de programas, modelos ou opções de reforma educativa são indicativos da preocupação dos países em organizarem seus sistemas nacionais de educação no século XIX e exemplos das formas como aconteceu o processo de apropriação ou circulação de idéias da área educacional no mundo ocidental.
} 
cabe ao comparativista reconhecer os limites e as potencialidades dos seus estudos e estabelecer as relações da comparação. Segundo Revel (1998),

(...) não existe, portanto hiato, menos ainda oposição, entre história local e história global. O que a experiência de um indivíduo, de um grupo, de um espaço permite perceber é uma modulação particular da história global (REVEL, 1998, p. 28).

A entrada das categorias ou temas de análise na perspectiva comparada entre os territórios (geográficos, científicos, sociais, por exemplo) deve ser, conforme alerta Detienne (2004), suficientemente genérica para atrair o trabalho de comparação, mas nem demasiado geral nem demasiada específica de uma só cultura. Não pode ser demasiado forte, ou seja, poderosamente classificatória de forma a dificultar o trabalho de confrontação, nem demasiadamente fraca, que nada ofereça a pensar o espaço e o trabalho em grupo. Deste modo, o conceito de territorialização das áreas de estudo deixa de ser percebido como um espaço fechado e delimitado, para se tornar locais a partir dos quais emergem diferentes formas de pensar e trabalhar temas, buscando não sua essência, mas percebendo melhor suas formas móveis e múltiplas. Caberia ao “comparativista" (DETIENNE, 2004) descobrir um conjunto de possíveis, cuja invenção conceitual mostraria elementos singulares e constitutivos de arranjos diversamente configurados. O estudo acerca das festas escolares realizado permite visualizar a discussão da territorialização quando apresenta, dentre as funções das comemorações, além da pedagógica e da educativa, a de reelaborar o imaginário social e político das sociedades brasileiras e portuguesas, não sem disputas e rupturas nos campos social, político e educacional.

A análise das discussões presentes no âmbito das ciências sociais no contexto do final do século XIX constituiu-se bastante fértil para a compreensão mais elaborada das relações entre os países, as disciplinas e as constituições dos campos designados científicos. Recuperando o conceito de campo de Pierre Bourdieu $(1990 ; 1996 ; 2004)^{11}$ é possível dizer que as ciências sociais adquiriram, no século XIX, uma forma nacional porque foram produzidas por agentes que habitavam um campo estruturado, governado por certas regras, detentores de um determinado habitus e que, por razões historicamente contingentes, possuíam uma extensão nacional ${ }^{12}$. Naquele contexto, as

\footnotetext{
${ }^{11} \mathrm{O}$ conceito de campo retomado no texto de Peter Wagner pode ser estudado de forma mais aprofundada a partir da leitura de obras do próprio autor.

${ }_{12}$ Convém assinalar que Pierre Bourdieu nunca elaborou análises sociológicas das formas de conhecimento que cruzaram as fronteiras. Mas, ao discutir a constituição dos distintos campos sociais
} 
"velhas" disciplinas como a ciência social foram definidas com bastante clareza e sem problemas mediante suas relações com as práticas institucionais sociais (WAGNER, 2006).

As relações que os cientistas sociais estabeleceram com o exterior, representado por outros países ou outras disciplinas, dedicaram-se ao desenvolvimento de uma definição e de uma demarcação dos seus campos respectivos, utilizando-se, para isso, não só de suas próprias teorias, mas também de fundamentos teóricos de outras disciplinas como a história e a geografia e/ou de teorias elaboradas por estudiosos de outros países; iniciava-se um movimento de tornar tais disciplinas menos "nacionais" e mais "internacionais", ou, em outras palavras, de tomar certo distanciamento das questões institucionais que as circundavam como forma de relativizar as influências sociais e históricas que recebiam na formulação de questões tratadas mundialmente, delimitando de forma mais sistemática o particular (singular, nacional) e o recorrente (exterior). O campo nacional como um espaço estruturado no qual era possível adotar uma variedade de posições caracterizou-se pela sua heterogeneidade; em outras palavras, não esteve unido só por relações de complementaridade, mas também por relações conflitivas dentro do mesmo, ou entre os campos (idem).

A compreensão de uma constelação histórica de campos relacionados entre si em um determinado momento histórico implicou a consideração da reestruturação das fronteiras dos mesmos campos nas relações transformadoras das práticas consideradas eruditas "nacionais" com outras dimensões. Neste caso, seria uma distorção apresentar as ciências sociais como tradições nacionais, mas também não se constitui um discurso plenamente internacional; no lugar disso, era possível observar lutas de poder intelectual acerca da interpretação da situação social delimitada. Tais aspectos abriram a possibilidade, fundamentada por Bourdieu (1990, 1996 e 2004), de uma estratégia de importação de elementos de um discurso externo ao campo nacional para intensificar a própria posição do indivíduo dentro do campo, e do campo diante de outras áreas, indicando que há sempre uma diversidade de posições dentro de um campo nacional (como um campo de força), o que permitiria análises muito mais refinadas e ricas na técnica comparativista (WAGNER, 2006) dentro do próprio campo ou entre os campos de um mesmo país ou de outras nações.

(político, econômico, cultural, religioso) converteu a extensão nacional dos campos em um tema implícito de outras investigações (WAGNER, 2006). 
As relações entre as diferentes áreas, bem como entre o micro e o macro e as passagens de um para o outro se constituiriam, desse modo, uma constante no trabalho de todo intelectual que desejasse criar comparações não só entre as diferentes realidades, mas entre os detalhes mais ínfimos do seu objeto e as relações que poderiam ser estabelecidas entre o tema escolhido e o contexto social e histórico mais amplo. A circulação das questões que podem ser tratadas de forma distintas em disciplinas concorrentes, por exemplo, ou a busca de objetos inéditos em outras áreas que auxiliam na fundamentação do tema são ações cada vez mais recorrentes nos âmbitos das produções intelectuais e indicam um esforço de renovação e reconhecimento de novas fronteiras entre os saberes.

A história comparada das festas escolares, concebida como elemento de uma determinada cultura escolar que se desejou internacional foi, e ainda o é, permeada pelas questões discutidas acerca da organização do campo. É inegável a sua apresentação como um elemento constitutivo de um modelo em sistemas escolares de diferentes países ocidentais; assim como aconteceu com a estruturação do tempo e do espaço escolar, as festas contribuíram para a identificação, no campo educacional, de um modelo considerado moderno de ensino. Por outro lado, a análise das comemorações não pode tomá-las como eventos homogêneos, apesar da estrutura organizacional que se repete, mas em diferentes contextos sociais e históricos ela foi ressignificada, foi objeto de lutas pelo poder dentro do campo educacional, beneficiouse de outras áreas para a sua legitimação (especialmente da Psicologia) além de ter sido apropriada pelos indivíduos de maneiras distintas e originais.

Os estudos acerca das novas relações entre as disciplinas e entre os países no século XIX podem ser melhor discutidas a partir do conceito de externalização elaborado por Jürgen Schriewer $(2000 ; 2001)$ que pretendeu dar conta das formas pelas quais aconteceu esta abertura para o "novo", para o "outro", para o "externo". É um conceito potencialmente rico para as investigações na área educacional e pode ser retomado para a compreensão dos processos de difusão internacional de modelos educacionais de referência e os seus processos de apropriação em vários países. Os exemplos e experiências realizados no estrangeiro e divulgados nos diferentes países deveriam servir como 'lições' que forneceriam 'ideias estimulantes' e 'novos impulsos para a definição de políticas ou para delinear um 'quadro de referência' internacional'. O modelo ocidental (Europa e América, principalmente) propunha um extenso catálogo de medidas para a reforma educativa assente em alguns princípios como: o 
estabelecimento de um sistema educativo nacional, a escolaridade de massas obrigatória até à idade de 14/15 anos, seguida de um ensino secundário e superior realizado em liceus, institutos superiores técnicos, institutos superiores de educação e algumas universidades funcionando como centros de aprendizagem e inovação científica. Além disso, os princípios organizativos enfatizaram recorrentemente a importância de um desenvolvimento polivalente da personalidade dos indivíduos, como fator responsável pelas suas ações e comportamentos, nos aspectos físico, intelectual e moral (SCHRIEWER, 2000, p. 104-105), conforme se tornou a bandeira dos pedagogos renovados em finais do XIX e início do XX.

A externalização como recurso às referências mundiais forneceu à reflexão reformadora em educação um extraordinário grau de dinamismo autorregulado (SCHRIEWER, 2000). As referências às situações mundiais, no caso da educação, vêm reforçar a externalização da organização sistemática do ensino, caracterizada pela sua natureza tripla: primeiro, a transmissão de uma ideologia da educação e do desenvolvimento particularmente moderno; segundo, a aceitação global de modelos racionais de escolarização pública conduzida pelo Estado; e, finalmente, o processo mundial de uma expansão educacional, que, depois de um começo hesitante no século XIX e inícios do século XX, atingiu seu máximo impacto na segunda metade do século $\mathrm{XX}$, em primeiro lugar com a obrigatoriedade escolar e, depois, com a implementação dos níveis de ensino secundário e superior (ibidem). Entretanto, as variações relacionadas a uma maior ou menor aproximação de um modelo mundial dependem das capacidades das sociedades de adotarem, transformarem e se apropriarem seletivamente de modelos internacionais, ou seja, da sua reflexividade:

(...) embora a modernidade, de acordo com Einsenstadt, represente um novo tipo de civilização global, isto não implica que o fenômeno da modernidade seja automaticamente sinônimo de uma adoção mundial de padrões uniformes de significação e organização. Aliás, a investigação inter-civilizacional tem mostrado o desenvolvimento de 'variantes básicas de modernidade' ou de 'programas múltiplos de modernidade’ (SCHRIEWER, 2000, p. 110-111).

O conceito de externalização pode, desse modo, ser complementado por outros como os conceitos de "autoreferência", "reflexividade" e "reflexão" elaborados no âmbito da sociologia do conhecimento por Luhmann (1981) e retomados por Schriewer (2000) como forma de orientar as investigações sobre os processos socioculturais e compreender como uma realidade social que se observou e se descreveu a si própria 
utiliza como referência a si e aos outros e como emprega esta autodescrição para se auto-organizar (SCHRIEWER, 2001). Neste sentido, os processos de apreciação e, possivelmente, de implementação de modelos e de concepções provenientes de outros países, foram marcados por certa filtragem, ou seja, as ideias originais não chegaram a ser implementadas exatamente como foram pensadas e concretizadas nos países de origem, embora passem por um processo de reflexão e de autorreferência que precisa ser considerado (LUHMANN apud SCHRIEWER, 2001, p. 14). As externalizações implicaram num movimento duplo de interpretação avaliativa dos dados, estruturas ou questões internacionais e extração de argumentos que sejam relevantes para as políticas e práticas educativas. Este procedimento, algumas vezes implícito de "observação internacional", adotado com a intenção de "sintetizar os problemas, idéias e correntes educacionais, comuns a todas as nações” (SCHNEIDER, 1931 apud SCHRIEWER, 2001), demonstrou o uso do método comparativo não somente para escrutinar as diferenças socioculturais, mas também para construir referências novas mais próprias aos países.

Considerando esta perspectiva, as várias nações, sociedades ou civilizações não foram tomadas como unidades de análise somente em termos de produtividade teórica, mas servem como unidades de referência ou "sociedades de referência", condutoras de uma suposta "internacionalidade" e modernidade ${ }^{13}$, como foi no século XIX. O conceito de externalização convida a que se coloque no centro da atenção analítica a apropriação interpretativa e a transformação das circunstâncias internacionais, dos corpos de conhecimento e dos modelos educacionais nos discursos sobre educação em diferentes contextos sociais, ou como conceituou Chartier (1992), suas diferentes apropriações. O desenvolvimento de teorias educacionais realizou-se essencialmente como reflexões sistêmicas que estão ligadas às várias condições dos contextos de partida, aos problemas, às tradições de pensamento e às preferências de valores dos seus sistemas de referência e contextos de reflexão. A reflexão sistêmica sobre educação apareceu forçosamente como uma forma marcada histórica e culturalmente (SCHRIEWER, 2001, p. 21) no século XIX.

As investigações no âmbito dos estudos históricos comparativos devem levar em consideração, além das mudanças de escalas e das trocas entre diferentes territórios

\footnotetext{
${ }^{13}$ De acordo com alguns estudiosos, o conceito de modernidade poderia ser aplicado aos pensadores iluministas do século XVIII (BОTO, 2011). Como o período de investigação desta tese está circunscrito ao final do século XIX e início do XX, momento no qual tais ideias consideradas modernas sobre o ensino puderam efetivamente ser concretizadas na implementação de sistemas estatais, gratuitos, laicos e democráticos de ensino e na disseminação das propostas educacionais com bases científicas da Escola Nova, utiliza-se o conceito de modernidade educacional para esse contexto em específico.
} 
científicos e de contextualização, a questão das categorias de estudo, concebida como uma das maneiras potencialmente profícua e bastante utilizada na elaboração da história da educação comparada, contribuindo para a confirmação da importância desta área de estudo. Nesta perspectiva, as categorias tradicionais de Estado-Nação ${ }^{14}$ e de escola graduada, percebida como parte deste modelo difundido na modernidade, constituem-se como referência aos estudos históricos comparativos, tanto para as análises mais amplas quanto para os estudos de objetos mais delimitados. Neste modelo de referência não existiram padrões uniformes de significação e organização, mas "variantes e multiplicidade dos programas da modernidade" (SCHRIEWER, 2000, p. 112) que mereceram ser conhecidos.

A título de exemplo, faz-se relevante retomar a proposta investigativa de António Nóvoa (2000) acerca da escola de massas em Portugal, Brasil e Moçambique. A primeira questão que o autor coloca referia-se aos sentidos de uma investigação como esta, que deve permitir conhecer a temáticas similares nos diferentes países, ultrapassando a tradição reducionista que propunha a comparação de políticas educativas mais amplas como eixo central das pesquisas. Concebida desta forma, as periodizações da história conhecida como tradicional ou oficial precisariam ser repensadas e até mesmo reformuladas de acordo não mais com o discurso e/ou fatos oficiais, mas agora, dos objetos antes desprezados, sob os quais incidiam a análise. $\mathrm{O}$ objetivo reside na ideia de que a história comparada da festa ultrapasse estes usos e construa novos sentidos, conforme proposto por Nóvoa (2000), para as relações entre os países mediante a seleção dos objetos de pesquisa representativos de realidades sociais determinadas.

Os procedimentos de comparação no âmbito historiográfico educacional adotado neste estudo, assim como propõem Nóvoa e Schriewer (2000), almejaram confrontar realidades distintas a partir de unidades analíticas a serem estabelecidas de acordo com as fontes. Não se pensou, evidentemente, somente na indicação de semelhanças e diferenças, mas sim, na análise de formas de criar sentidos capazes de estabelecer proximidades e afastamentos com relação a modelos de implantação de ideias e práticas na área educacional. De acordo com Catani (2007), a escrita da história comparada Brasil-Portugal deve inscrever-se em uma "história das relações", ou ainda,

${ }^{14} \mathrm{O}$ conceito de Estado-Nação constituiu-se referência para a organização dos países ocidentais que almejaram sua autonomia social, política e econômica. Tais países denominados como Estados-Nação deveriam reunir algumas características fundamentais: um território definido e fechado, a mesma língua falada pelos integrantes deste território, mesma cultura e governo. 
segundo Antonio Nóvoa (2000), em uma "história dos sentidos", cuja proximidade linguística dos países permite conhecer diferentes temáticas para além da empiria, mas como uma teoria, estabelecida na relação que a história construiu entre esses povos e locais ${ }^{15}$. Estes sentidos podem ser engendrados a partir de uma análise mais detida entre os fenômenos globais e locais e nas formas como estes podem influenciar as práticas das instituições escolares (CARVALHO, CORDEIRO, 2002), assim como as representações negociadas entre as autoridades de ensino, inspetores, professores e alunos acerca das comemorações escolares nas escolas primárias.

A retomada dos estudos históricos comparados no campo educacional acontece na década de 90 do século XX por meio da prática de investigadores pertencentes a grupos internacionais (Stanford) ${ }^{16}$, que integraram aos seus trabalhos, elementos característicos de um raciocínio comparado, desejando conhecer as realidades nacionais “não apenas como 'empiria' (como casos, ilustrações ou exemplos), mas como 'teoria' ou a relação que a história construiu entre estes povos e países" (NóvOA, 2000, p. 121). No caso das comparações entre Brasil e Portugal, a proximidade linguística dos países deve permitir o estudo a partir do estabelecimento de uma "comunidade de sentido". A história comparada das festas escolares almeja, para além da comparação dos casos, exemplos e ilustrações, elaborar uma teoria que permita a sua compreensão como uma questão autônoma que perpassa as duas realidades selecionadas; nas palavras de Nóvoa (2000, p. 129): "um conhecimento novo (teórico) sobre a gênese e a expansão da Escola", adotando para isso um nível intermediário de análise entre as concepções do sistema mundial e as aproximações centradas nos estados nacionais.

\footnotetext{
${ }^{15}$ Cabe destacar, neste sentido, algumas teses de doutorado recentes elaboradas dentro desta perspectiva: SILVA, Vivian B. Saberes em viagem nos manuais pedagógicos: construções da escola em Portugal e no Brasil (1870-1970). São Paulo: FEUSP, 2006; XAVIER FILHA, Constantina. Discursos da intimidade: imprensa feminina e narrativas de mulheres-professoras brasileiras e portuguesas na segunda metade do século XX, São Paulo: FEUSP, 2005 e SILVA, Vera Lúcia Gaspar da. Sentidos da profissão docente: Estudo comparado acerca de sentidos da profissão docente do ensino primário, envolvendo Santa Catarina, São Paulo e Portugal na virada do século XIX para o século XX. São Paulo: FEUSP, 2004.

${ }^{16}$ A teoria elaborada pelos estudiosos da Universidade de Stanford acerca das trocas internacionais tem suscitado muita atenção, quer no sentido histórico, quer teórico, relativamente à difusão mundial e aceitação de modos, ideologias e padrões de organização sociocultural, especialmente, o do Estado-nação e os seus atributos institucionalizados. As ideologias e os sistemas educacionais modernos nasceram na Europa dos séculos XVIII e XIX e ganharam aceitação global durante a segunda metade do século XX (SCHRIEWER, 2000, p. 107), tal movimento indica a existência de uma ordem político-cultural estandardizada como pretensão de validade universal. "No contexto deste modelo, as idéias centrais do estado nacional moderno e do progresso socioeconômico estão intimamente ligadas às noções universais de educação institucional e de desenvolvimento individual da personalidade" (SCHRIEWER, 2001, p. 20). $\mathrm{O}$ modelo de Stanford destaca o papel central de intermediário que uma ciência da educação racionalizada, com recurso à psicologia experimental e à economia, desempenha na difusão de idéias e modelos político-educacionais e aspira a uma validade e prestígio universais.
} 
O movimento de escolarização das $\operatorname{massas}^{17}$, por meio de políticas educacionais e da criação de um modelo escolar - dos grupos escolares no Brasil e escolas centrais em Portugal, bem como a elaboração de um discurso moderno sobre o ensino constituíram-se em duas referências importantes para a criação de instrumentos de interpretação das relações entre os países no contexto de difusão mundial de um modelo escolar, que acompanharam, em um contexto mais amplo, a afirmação e o desenvolvimento dos Estados-Nação. A denominada "escola de massas", ou seja, escola para as populações ministrou o ensino de forma a garantir a unidade nacional, a educação para a cidadania e a promoção da integração política dos seus países por meio de metodologias que visaram normatizar os cidadãos, suas línguas e seus modos de viver. Neste sentido, a inserção das discussões acerca do modelo mais apropriado de escolarização em projetos políticos e sociais mais abrangentes não são resultado de uma necessidade da evolução da humanidade que chegou a um determinado grau de civilização, mas a causas definidas e a estados sociais muito particulares que mereceram ser conhecidos (VINCENT, LAHIRE e THIN, 2001). Naquele contexto, as instituições de ensino colaboraram com o projeto do Estado mediante a institucionalização de uma organização e modos de trabalho específicos a ela:

(...) classes graduadas agrupando os alunos; professores atuando individualmente junto a uma turma de estudantes, com perfil de generalistas, no caso do ensino primário, e de especialistas, no ensino secundário; lugares estruturados com arquitetura específica, nos quais a sala de aula sempre foi o espaço privilegiado de estudo; tempos específicos para as atividades e saberes produzidos para, pela e na escola, compondo o seu currículo (NóvOA, 1995).

Os enredos e tramas que unem as histórias políticas, econômicas e culturais de Brasil e Portugal antecedem a data inicial dessa pesquisa no século XIX e possuem uma longa narrativa prévia que não pode ser desconsiderada nas comparações realizadas entre os dois países. A interdependência das relações iniciais entre a metrópole e as colônias, que acabaram por transformar os territórios coloniais em lugares de experimentação para tecnologias de governo e, dentre estas, as escolares que, mais tarde, deveriam ser utilizadas nas metrópoles (NóvoA, 2000) não podem ser omitidas. A ideia recorrente que associou da expansão da escola à distinção dos países entre os

\footnotetext{
${ }^{17}$ A expansão da escola de massas intensificou-se em várias partes do mundo depois da década de 50, mas o processo evidenciou-se a partir de 1870 em espaços organizados como Estados-Nação (SILVA, 2005).
} 
exemplos de modernidade a serem seguidos, e os outros que deveriam aprender com "os mais desenvolvidos" a organizar seus sistemas de ensino, analisadas à luz das relações entre Brasil e Portugal é possível assinalar que Portugal não tinha o Brasil como uma sociedade de referência, ou seja, conhecer as experiências brasileiras era mais uma tentativa de confirmar a primazia portuguesa na área da educação e da produção de conhecimentos e não de buscar referências ou exemplos (SILVA, 2005). Entretanto, não é possível afirmar a existência de uma organização hierárquica e vertical entre os saberes; estes, não circularam num único sentido, desde as nações mais desenvolvidas para as menos: "Pelo contrário, o global e o local estiveram, nessa perspectiva relacionados mediante padrões complexos que foram múltiplos e multidirecionais" (PoPKEWITZ apud SILVA, 2005, p. 14). Sendo assim, há que se considerar essas relações em um movimento de intercâmbio de ideias, modelos, experiências e não só de imposições e adaptações.

A partir das investigações históricas educacionais realizadas em Portugal e em outros países, A. Nóvoa (1998) assinala que a periodização das pesquisas comparadas poderia realizar-se em ciclos de quarenta anos, concedendo particular atenção a grandes momentos de viragem do modelo escolar: décadas de 1880, de 1920 e de 1960. A data para o início da pesquisa aqui delineada, 1890, explica-se pela gradativa organização dos sistemas estatais de ensino nos dois países a partir de finais do século XIX, em anos diferentes, e no âmbito destes sistemas do lugar ocupado pelas das festas escolares, bem como ampla difusão de um discurso modernizador para o ensino em meios como os periódicos e manuais pedagógicos ${ }^{18}$, cujas justificativas teóricas confirmaram a realização das festas como atividades de características pedagógicas. Foi neste contexto também, que foi possível localizar as primeiras referências às festas escolares em periódicos portugueses.

A data final, 1930, coincidiu com a diminuição das referências às comemorações escolares nas fontes selecionadas para o estudo, cuja hipótese foi a de que as comemorações tinham cumprido parcialmente a sua função de disseminação de um modelo de ensino moderno e adquiriram novos significados com a mudança de regimes políticos nos países em questão. Com a seleção dessas datas almejou-se

\footnotetext{
${ }^{18}$ Conceituados como livros destinados e utilizados pelos alunos da Escola Normal, futuros professores das escolas primárias, diferentes, em sua natureza e forma, dos textos usados nas aulas dos alunos do ensino primário (SILVA, 2005). Foram livros impressos, geralmente em grande número, para constituírem-se literatura básica nos cursos de formação de professores, contribuindo assim, para a difusão de uma cultura profissional do magistério (PERRENOUD, 1995).
} 
identificar os usos e funções atribuídas às comemorações escolares em um período de estruturação ainda incipiente dos sistemas estatais de ensino, suas contribuições para este processo, seu lugar na cultura específica da escola, bem como a sua participação na unidade de uma configuração histórica particular (VINCENT, LAHIRE e THIN, 2001). Tratou-se de indicar qual foi o papel das festas escolares na constituição dos sistemas públicos e laicos de ensino, associados ao discurso que pretendia a modernização da escola e que teve seu auge nas últimas décadas do século XIX e início do século XX, tendo sido ressignificados e, em alguns momentos, transformados pelos regimes autoritários que assumiram o poder tanto em Portugal quanto no Brasil na década de 1930.

Ao selecionar as décadas de 1890 até 1930 para início e término da pesquisa comparativa nos dois países, procurou-se relativizar o peso dos regimes políticos em questão, República (primeiras décadas do regime) no Brasil e em Portugal, com o Ultimato inglês em 1890 que inicia o processo de desmantelamento da Monarquia portuguesa até a Proclamação da República em 1910, e compreender o objeto em uma configuração própria de um modelo escolar mundialmente difundido, seu lugar nas tentativas de elaboração de uma ciência da educação no decurso da década de 1880 e na emergência do movimento da Escola Nova ${ }^{19}$ nos anos 1920 (NóvoA, 1998). As datas finais coincidem nos dois países com a organização e implementação de governos autoritários: Antonio Salazar em Portugal e Getúlio Vargas no Brasil. Entretanto, não se almejou diminuir a importância das diferentes configurações políticas para o estudo das festas, mas relativizar a aproximação, bastante comum em estudos da área, entre as mudanças empreendidas na escola e o regime político em vigência.

Em Portugal como no Brasil, a imposição do ensino primário e da escolaridade obrigatória fundamenta-se nos princípios de que só assim se formam cidadãos patriotas e cumpridores das leis e cada um dos países se coloca no grande concerto das nações civilizadas. A generalização da instrução primária elementar revela ser uma bandeira política prioritária com vista a forjar a identificação com a Nação enquanto comunidade imaginada (CORREIA, GALLEGO, 2004).

\footnotetext{
${ }^{19}$ A Escola Nova foi uma maneira distinta de conceber a educação, rompendo com o que na época se convencionou chamar Educação Tradicional, As escolas renovadas pretendiam-se contrárias às escolas tradicionais: "situadas no campo se possível, num protesto contra o surto urbano do industrialismo, estas escolas eram (ou pretendiam ser) arejadas, doces, com crianças evidenciando um ar livre e feliz" (CANDEIAS e NóvOA, 1995, p. 14), além disso, modernas, introduzindo métodos pedagógicos baseados em estudos científicos acerca dos aspectos afetivo, social, intelectual, entre outros, da criança.
} 
Convém assinalar que a busca por similaridades e distanciamentos dos eventos festivos nos dois países foi fundamentada na implementação de um modelo representativo da modernidade escolar no século XIX nas duas realidades, e definido genericamente como escolas graduadas. Muitos estudos se multiplicam acerca do processo de constituição do modelo moderno de escola nos países ocidentais em finais do século XIX e início do século XX (Inglaterra, Alemanha, de modo especial a Prússia, Áustria, França, Espanha, Portugal e Estados Unidos, por exemplo). No período considerado para a pesquisa (1890-1930), aquilatar o desenvolvimento e o progresso dos países, denominados Estados-Nações, foi definir também o quanto se investiu em educação, quais os esforços realizados por cada país para o aprimoramento do seu sistema de ensino, bem como o real empenho em se aproximar do ideal divulgado no projeto modernizador do ensino. $\mathrm{O}$ interesse pelo tema identificou-se com a permanência deste padrão institucional durante um longo período na história da educação de diferentes sociedades e das suas representações concernentes ao potencial disseminador de um ideal educativo.

O esquadrinhamento da escola moderna, mass scholing ou escola graduada, sinônimos para a mesma instituição, se realizou em estudos da área históricoeducacional por meio da análise de diferentes aspectos que a constituíram enquanto elemento definidor das sociedades consideradas modernas. A organização do espaço escolar (MONARCHA,1999; SOUZA, 1998; TANURI, 1979), do tempo e dos currículos (GALleGO, 2003), dos manuais a serem utilizados (SILVA, 2005) e da formação dos professores (CARVALHO, 1998; CATANI, 2003) foram elementos explorados para a compreensão mais acurada da consolidação da modernidade pedagógica no Estado de São Paulo. Apreende-se que as escolas graduadas tiveram uma organização interna bastante semelhante nos dois países em estudo caracterizadas por períodos determinados para matrícula dos alunos, organização e seleção das disciplinas que deveriam figurar obrigatoriamente nos currículos escolares, organização do tempo de aula e dos dias letivos, incluindo o período de férias e das festas escolares (CORREIA, GALLEGO, 2004; GALLEGO, 2008), que estiveram presentes nestas duas realidades educacionais, apresentando rituais bastante semelhantes, mas propósitos e temas diversos, cujas categorias estão sublinhadas no corpo desta tese.

Além da organização estrutural e administrativa das escolas graduadas, a modernidade pedagógica caracterizou-se por um conjunto de idéias que se organizaram no decorrer do século XIX acerca das melhores formas de instruir e "governar" as novas 
gerações, considerando o papel fundamental da escola na produção de 'sistemas de governo’ (NóvoA, 2000). O período considerado desde o último quartel de oitocentos até meados do século XX é indicado pelos historiadores da educação como de fundamental importância para a compreensão do processo de arrancada do projeto sociopolítico de escolarização massiva e da constituição de uma unanimidade científicosocial representada pelo domínio da psicopedagogia de base experimental e, posteriormente, pelo movimento da Educação Nova das primeiras décadas do século XX (CARVAlHO; Ó, 2009).

Desse modo, o projeto moderno de escola fez parte de um plano mais amplo de articulação entre as dinâmicas de constituição da subjetividade e os objetivos de governo das populações nos Estados-Nação. As técnicas utilizadas para governar as populações, agora organizadas dentro de limites específicos dos países seriam as mesmas empregadas na organização do paradigma moderno de ensino (Ó, 2006). O governo da população passava pelo governo dos indivíduos e pelo incentivo a um comportamento plenamente submetido às regras sociais, aprendidas desde a mais tenra idade no microcosmo escolar. A ideia de modernidade no ensino esteve associada à busca do controle e do aprendizado maximizado em todas as lições escolares, inclusive nas festas, que se constituíram em ocasiões oportunas para a retomada dos conteúdos aprendidos nas salas de aulas, agora de maneira mais "ativa", dos modos de organizar e realizar as festas e suas funções e por último, dos saberes e comportamentos desejados para apresentação ao público nessas ocasiões.

As relações entre o projeto de instituição da modernidade escolar e a prática das festas escolares não estiveram indicadas de forma explícita nos discursos e textos produzidos pelos educadores da época e registrados nas fontes estudadas, mas se associaram de forma tácita aos objetivos de formação presentes neste projeto. Como exemplos, a utilização das festas para o desenvolvimento da inteligência, da sensibilidade, da vontade e da disciplina, no reforço dos saberes curriculares aprendidos, na legitimação da instituição escolar, na definição de um habitus professoral e escolar, bem como na indicação de questões educacionais constituintes do campo. Destacada pela importância da realização das atividades festivas pelos alunos e visando o desenvolvimento integral destes, as comemorações significariam uma maneira de ensinar mais dinâmica e menos teórica, como propunham as tendências modernas do ensino. 
As discussões acerca da modernidade pedagógica relacionam-se ainda à constituição de uma estrutura escolar comum em países como Brasil e Portugal, o que valida a relevância do estudo das festas escolares no âmbito da pesquisa histórica comparativa educacional, perspectiva considerada fértil pelos pesquisadores da área para o tratamento das questões relacionadas à história da educação nos países lusófonos (Brasil, Portugal, Moçambique, Timor Leste, Angola, Guiné-Bissau, São Tomé e Príncipe e Cabo Verde). Desse modo, quando falamos das comemorações escolares enquanto práticas das escolas públicas paulistas e portuguesas, tão importante quanto descrever os modos pelos quais elas eram realizadas pelos docentes e alunos, suas temáticas, práticas, as diferentes datas, representações e apropriações (CHARTIER, 1992), foi compreender, também, o papel que elas assumiram para a constituição de um modelo escolar engendrado mundialmente pelos Estados-Nações e os sentidos a elas atribuídos (NÓvOA, SCHRIEWER, 2000).

No caso do estudo das festas escolares, foi possível construir três categorias internas que se repetiram nas sociedades brasileiras e portuguesas para a análise das mesmas: 1) as festas cívicas escolares, as mais documentadas, eram as mesmas festas comemoradas na sociedade republicana, mas organizadas de acordo com um ritual específico da escola, constituíam-se objetos de disputa pelo poder dos dirigentes da República; 2) as festas que comemoraram as instituições de ensino e seu ciclo de vida, buscando dar visibilidade às mesmas, foram as festas de inauguração, aniversário e encerramento do ano letivo; e por último, 3) as festas da natureza, representadas nas árvores e nas aves, que almejaram despertar nos alunos o interesse pela natureza como representante máxima da pátria brasileira. Além destas, outras categorias foram criadas para dar conta das especificidades festivas dos dois países (as festas beneficentes em Portugal, por exemplo). Ao tratarmos das distinções entre as temáticas festivas, é possível perceber uma determinada regularidade nos rituais festivos ou práticas da festa que, segundo alguns estudiosos, seriam os elementos capazes de garantir o fascínio e a adesão popular às festas em geral (OzOUF, 1976).

Os rituais das comemorações escolares eram compostos, na sua maior parte, de homenagens às pessoas ilustres que compareciam nestas ocasiões, como diretores de ensino, inspetores escolares, secretários do interior, os prefeitos das localidades, vicepresidentes do Estado e professores; declamação de poesias pelos alunos, hinos, marchas, apresentações de peças teatrais, passeatas pela cidade; preparação de banquetes, lunchs e soirées pelos professores e alunos; sessões literárias, exercícios 
orais sobre as disciplinas estudadas, distribuição dos boletins de promoção e de prêmios oferecidos pelos professores aos seus melhores alunos, torneio ginástico, plantio de mudas, nas festas das árvores, apresentação dos escoteiros, nas festas cívicas e hasteamento do pavilhão nacional, que depois se tornou uma prática cotidiana das escolas públicas.

No âmbito social e político, as celebrações escolares possuíram como objetivo, deixar bem patente para a população como um todo, não só a escolar, os progressos e o empenho do governo republicano no âmbito educacional. As escolas representavam, para os dirigentes republicanos, a possibilidade do progresso econômico e social do país, e somente através delas a população poderia e deveria instruir-se. As comemorações de aniversário, inauguração e de encerramento do ano letivo contribuíam para a disseminação da ideia considerada moderna sobre a importância da instrução e das escolas para os países que se queriam desenvolvidos. Já as festas cívicas evidenciavam a relação com o sistema político então vigente, seja na celebração dos ideais e valores republicanos, seja por meio da escolha das datas e temas que deveriam ser comemorados, além dos rituais praticados.

A pertinência do estudo socio-histórico comparado esteve não somente nas descrições mais ou menos exatas e fidedignas do objeto festa em Brasil e Portugal, atentando-se ao fato de conhecê-las para reconstituí-las, mas sua justificativa fundamentou-se na possibilidade de compreensão da sua circulação nas diferentes realidades, suas apropriações e participação na constituição de um campo educacional com características públicas e estatais. Trata-se de compreender nas diferentes dimensões da vida social e individual qual papel assumiram as festas nos projetos educacionais dos dois países, quais seus elementos comuns, suas representações fundamentais e atitudes rituais, como eles se constituíram e se modificaram no tempo e no espaço.

Uma primeira incursão pelo objeto desta tese permitiu conhecer, em um contexto social e histórico delimitado, dois níveis marcantes de significação para o objeto: um indicado por aqueles que pensavam as festas e as suas contribuições para o âmbito social, político e educacional, e outro apropriado pelos indivíduos que realizaram as festas, além das variações temáticas perceptíveis nas duas realidades. Se os temas e propósitos variaram no contexto delimitado para os dois países, foi possível reconhecer uma mesma função educativa para as festas ao selecionarem e difundirem 
conhecimentos escolares não só para a população educacional, mas para toda a comunidade que dela participava. Muito mais do que a alegria e a liberdade que caracterizaram as festividades em outros locais, nas escolas, elas ganharam contornos singulares, uma liberdade regulada, um saber esquadrinhado com o objetivo de garantir sua finalidade pedagógica.

\section{Dos modos de realizar a pesquisa acerca das festas escolares}

A elaboração do estudo das festas escolares no contexto de disseminação de uma estrutura ideal de ensino, representada pelos grupos escolares, e da elaboração de um discurso educacional científico, a modernidade educativa, realizou-se mediante a leitura de teóricos da área de história e de história da educação, tanto no Brasil quanto em Portugal, de estudiosos de campos distintos, mas relacionadas à história, bem como de fontes primárias, como os manuais pedagógicos destinados aos alunos e professores (portugueses e brasileiros), alguns títulos de periódicos de ensino, alguns textos legais e das fotografias que, porventura, fossem publicadas nesse material. A análise histórica da cultura escolar tem se beneficiado da utilização de fontes de estudo antes desprovidas de legitimidade e objetos de estudo inéditos ganham estatuto autêntico nessa perspectiva. Como exemplos, podemos identificar os materiais de alunos e professores para estudo da escrita, da ortografia, da gramática; dos periódicos educacionais para estudo dos saberes profissionais docentes e dos debates educacionais em voga; das fotografias para estudo das práticas escolares, tais como aulas de exercícios físicos e as festas escolares. Além de buscar novas fontes, convém aos historiadores recontextualizar as fontes das quais dispõem, estar cônscio de que a "grande inércia" que se apreende em nível global pode estar acompanhada de modificações muito pequenas que insensivelmente transformaram o interior do sistema; neste caso, convém não deixar se enganar inteiramente pelas fontes mais normativas que lemos, acreditando que essas retratam de forma fidedigna os objetos de estudo (JULIA, 2001).

A escolha dos manuais pedagógicos e a posterior análise de informações sobre o tema da tese localizadas nos mesmos justificou-se por dois motivos principais: o primeiro pelo fato deste material ter sido amplamente utilizado nas escolas de formação de professores em um período crucial que foi a constituição e consolidação da carreira docente e do campo educacional - foi neste período que a profissão de educador 
diferenciou-se de outras, fundamentando-se em saberes reconhecidos cientificamente sobre os métodos de ensino e o desenvolvimento psicológico dos educandos; segundo, pelo fato dos manuais pedagógicos terem sidos os responsáveis, na maior parte das vezes, pela tradução dos saberes científicos reconhecidos socialmente, por exemplo, nas teorias dos pedagogos renovados, para o âmbito da sala de aula e da prática de ensino. Os manuais foram primordiais para a divulgação e compreensão de teorias pedagógicas que estavam sendo produzidas em outros países e que, de forma reiterada, foram utilizadas na definição do que deveria ser a nova escola. Tratou-se de investigar como os distintos manuais apresentaram e/ou transformaram os discursos considerados mais teóricos ou científicos sobre as festividades escolares em orientações para os mestres e futuros mestres ou, como diria Silva $(2005)^{20}$ retomando o educador Rafael Grisi (1956, $4^{\mathrm{a}}$. ed.), de fazer com que "os saberes do céu" - alusão aos tratados pedagógicos elaborados por autores reconhecidos no campo científico e educacional, "descessem à terra", ou seja, até a prática cotidiana dos professores e dos seus alunos. Os escritos desses manuais e dos periódicos analisados se complementaram ao tratarem de uma visão da festa na sua idealização ou no seu discurso manifesto, no caso dos manuais. Estas considerações não isentam, entretanto, as influências e/ou o jogo de interesses que poderiam estar implícitos nos discursos produzidos acerca das festas escolares.

Com relação aos periódicos educacionais, seus usos como fontes de estudo para objetos relacionados à educação se fazem importantes, pois, além de se constituírem como um excelente observatório das questões educacionais, capazes de identificar a multiplicidade do campo educativo, por meio deles pode-se perceber as vozes, os projetos e as realidades dos diversos atores envolvidos, bem como as formas pelas quais os anseios republicanos para o sistema educacional repercutiram no âmbito escolar; aproximando-se um pouco mais das práticas, enfim:

A análise da imprensa permite apreender discursos que articulam práticas e teorias, que se situam no nível macro do sistema mas também no plano micro da experiência concreta, que exprime desejos de futuro ao mesmo tempo que denunciam situações do presente.

\footnotetext{
${ }^{20}$ No âmbito dos estudos realizados acerca dos manuais pedagógicos, destaca-se a tese de doutoramento de Vivian Batista da Silva (2005), defendia na Faculdade de Educação da Universidade de São Paulo. Neste trabalho, a autora elabora "a história dos manuais pedagógicos", ou seja, investiga a constituição de determinadas leituras para professores, desde a edição dos títulos mais antigos, da década de 1870, até o século seguinte, quando se configura um conjunto de técnicas editoriais que permitem outras modalidades de escritos. A autora concebe esses escritos como documentos fundamentais para a compreensão da escola em determinados períodos históricos pela existência, nesses materiais, de uma série de recomendações e de saberes, dentre estes os festivos, capazes de corporificar e produzir a realidade escolar, bem como fundamentar um modelo de escola a ser seguido.
} 
Trata-se, por isso, de um corpus essencial para a história da educação, mas também para a criação de uma outra cultura pedagógica (NóVOA, 1997, p.11).

A criação e manutenção de periódicos de ensino foram consideradas maneiras específicas do processo de organização do campo educacional em finais do século XIX, entendido como o espaço que inclui a vida e os interesses de grupos profissionais, a elaboração e difusão de trabalhos capazes de estabelecer formas legítimas de tratamento para as questões de ensino, as instituições escolares e os mecanismos capazes de manter o campo delimitado e em atividade (CATANI, 2003). De acordo com Carvalho (1998), estes impressos devem ser analisados como objeto cultural que guardaram as marcas de sua produção e de seus usos, além de "suporte material de práticas pedagógicas na sala de aula..." (CARVAlho, 1998, p.35). Além disso, por meio das revistas de ensino é possível escrever uma história das práticas escolares que compreenda melhor a "riqueza das iniciativas locais institucionais, ideológicas, sócio-profissionais e também ao atendimento de expectativas" ao invés, simplesmente, das iniciativas do Estado ou dos "grandes pedagogos" (CASPARD, 1993, p. 93 apud CATANI; SouSA, 1999, p. 14). Além disso, os periódicos educacionais são fontes férteis de estudo porque se tornam guias práticos do cotidiano educacional, permitindo ao pesquisador estudar "o pensamento pedagógico de um determinado setor ou de um grupo social a partir da análise do discurso veiculado e da ressonância dos temas debatidos, dentro e fora do universo escolar" (CATANI et al., 1997, p. 5).

Os artigos selecionados nos periódicos trataram de maneira mais ou menos explícita a questão das festas, já que nem sempre os artigos trouxeram, em seus títulos, as palavras festas ou comemorações, mas, ao abordarem outras questões do universo escolar, como os exames, o ensino do civismo, da música, o encerramento do ano letivo, as inaugurações e aniversários das escolas, as homenagens aos professores, os cuidados com a natureza, à moral e a disciplina escolar, abordaram de maneiras nuançadas o objeto. Isto é, por meio das representações elaboradas pelos atores escolares e registradas nessas fontes, indicando como deveriam e como realmente aconteceram as festas foi possível nos aproximarmos um pouco mais das vivências das práticas festivas e do lugar ocupado por elas no campo educacional. A seguir, faz-se relevante apresentar uma breve descrição dos periódicos selecionados para esta investigação para, posteriormente, nos determos nos procedimentos referentes à coleta, sistematização e análise dos dados. 
Os manuais e periódicos formam consultados em diferentes bibliotecas brasileiras e portuguesas com o objetivo de localizar alguma referência ao tema estudado. Dentre esses, alguns foram descartados por não aludirem ao tema; por esse motivo, optei por listar e descrever somente os títulos efetivamente utilizados. Em São Paulo, as tarefas relacionadas à seleção, coleta e sistematização das informações referentes ao tema foram realizadas a partir de fontes primárias localizadas nos principais acervos da cidade de São Paulo: Paulo Bourroul e Macedo Soares, da Biblioteca da Faculdade de Educação da Universidade de São Paulo; o Instituto de Estudos Educacionais Sud Menucci; a Biblioteca Municipal de São Paulo e o Arquivo do Estado de São Paulo e em Lisboa, Portugal, Biblioteca do Instituto de Educação, na Faculdade de Letras e de História da Universidade de Lisboa, na Biblioteca Nacional, na Escola Superior Normal de Lisboa e no ISCTE (Instituto Universitário de Lisboa). Nestes locais, realizou-se a leitura de todas as fontes, investigando em cada número alguma referência ao tema ou a questões correlatas que pudessem fundamentar as nossas análises.

As fotografias localizadas neste corpus, especialmente nos periódicos de ensino brasileiros, foram retomadas neste trabalho como forma de ilustrar as discussões que estavam sendo feitas nos capítulos, aproximando-as o máximo possível das análises, sem desconsiderar o potencial analítico deste material para tratar de outras questões. A utilização dessas, em alguns casos, substituíram as descrições dos eventos, como se a sua presença nas páginas das revistas atestassem a concretização das solenidades e a sua veracidade. De acordo com alguns estudiosos do objeto fotografia (BARTHES, 1990; SONTAG, 2004), a realidade sempre foi interpretada por meio das informações fornecidas pelas imagens, cujas análises iconográficas são sempre históricas e dependentes do saber do leitor, tal como se fosse uma verdadeira língua, inteligível apenas para aqueles que aprenderam seus signos. Neste sentido, a fotografia enquanto mensagem é constituída por uma fonte emissora, um canal de transmissão e um meio receptor (BARTHES, 1990), sendo que estas três partes tradicionais da mensagem comportam métodos de interpretação diferentes. No nosso estudo, atentou-se para as especificidades as fontes emissoras, no caso os periódicos de ensino e aos elementos visualmente apresentados como possibilidades propostas ao leitor para elaborar imagens mentais acerca das celebrações que estavam sendo discutidas. 


\section{- Periódicos de ensino brasileiros:}

A Eschola Publica (1895-1897) - A Eschola Publica surgiu em 1893 e foi um dos principais periódicos especializados em educação editados em São Paulo nas últimas décadas do século XIX. Inicialmente, foi organizado pelo grupo de professores Oscar Thompson, Joaquim de Sant'Ana e A. R. Alves Pereira, que o mantinham com os seus investimentos particulares. Por esse motivo, A Eschola Publica enfrentou inúmeras dificuldades financeiras, sendo sua publicação interrompida em 1894 e reativada somente em 1896, graças ao auxílio de subvenções do Estado. Os artigos sobre o tema foram localizados, principalmente, na seção "Boletim", que depois se transformou em "Noticiário", responsáveis pela apresentação de notícias sobre as festas que aconteciam nas escolas públicas paulistas.

Revista de Ensino (1902-1919): em abril de 1902 a Associação Beneficente do Professorado Público de São Paulo iniciou a publicação da Revista de Ensino. O periódico foi um importante veículo divulgador da Associação e dos seus ideias, através dele pôde-se testemunhar os esforços da mesma para concretizar suas propostas iniciais: "defesa do grupo profissional, o aprimoramento intelectual, a prestação de serviços de saúde e a assistência financeira em caso de moléstia, invalidez ou necessidade momentânea, além da assistência jurídica" (CATANI, 1989, p.44). A Revista de Ensino, desde seu primeiro exemplar, comprometeu-se com os interesses da instrução e com os direitos do professorado. De modo abrangente, a Revista apresentou discussões sobre questões gerais as quais, no seu parecer, o professorado não podia estar alheio, estabelecendo um debate sobre a elaboração das leis, fornecimento de material e orientação ao trabalho dos professores, informação e divulgação de críticas sobre obras didáticas, além de defesa dos direitos do professorado.

As críticas agudas à atuação do governo e à situação da educação pública em São Paulo, veiculadas pelo periódico em 1904, fizeram com que a Revista perdesse o apoio inicial do Estado e deixasse de ser impressa pela Tipografia do Diário Oficial em 1905 (CATANI, 1994). A Revista de Ensino circulou até 1918. Nesse periódico, as informações sobre as comemorações escolares foram selecionadas das seguintes seções: "Pedagogia Prática", "Noticiário", "Questões Gerais", "Diversos”, "Literatura Infantill", "Variedades", "Notas", "Em classe e para classe", "Divagações" e "Os nossos edifícios escolares".

Revista Escolar (1925-1927): foi um periódico mensal, publicado entre janeiro de 1925 a setembro de 1927, pela Diretoria Geral da Instrução Pública do Estado de São Paulo; ao todo foram editados 33 números. Este periódico foi oficializado pela Lei 2182-B, de 29 de dezembro de 1926, que também definiu o seu corpo editorial. A partir daquela data, a Revista passou a receber verbas próprias, o que não acontecia anteriormente. Sendo a Revista um órgão da Diretoria Geral, podemos inferir que ela tinha a mesma orientação da Reforma de 1925, que foi elaborada pela Diretoria sem a participação dos professores e, por esse motivo, teve sua publicação criticada por outros profissionais do ensino. Na Revista Escolar, os artigos sobre festas eram 
apresentados nas seções: "Pelas Escolas", "Literatura Infantil", "Notícias" e "Questões Gerais".

Anuários de Ensino do Estado de São Paulo (1907-1926): os Anuários circularam entre 1907 e $1937^{21}$ e constituíram uma fonte de pesquisa muito fértil, uma vez que trouxeram relatórios dos inspetores escolares da época, com observações peculiares (CATANI, 1989). A partir dos Anuários, pôde-se ainda perceber o que era exigência do Estado para a educação, quais eram as reformas e as determinações estabelecidas através de leis e regulamentos e a avaliação dos seus resultados, feita pelo governo (CATANI; LIMA, 1997, p.168). Ele ofereceu numerosas informações a respeito do sistema de ensino paulista apresentando uma grande quantidade de dados estatísticos com o principal objetivo de divulgar os progressos alcançados em matéria de ensino (CATANI, 1994).

A publicação veiculou ainda várias listagens relativas à identificação das escolas isoladas e grupos escolares de municípios do interior, e diversas relações contendo nomes de funcionários que atuaram em cada estabelecimento e nomes de professores com as respectivas disciplinas que lecionaram. Além dos dados estatísticos, encontraram-se nessa publicação, relatórios de Inspetores e Diretores Gerais do Ensino, enviados anualmente ao Secretário dos Negócios do Interior, nos quais foram feitos comentários a respeito do progresso do ensino, seus problemas, os métodos de ensino empregados e os resultados práticos alcançados. A publicação e circulação destas informações no campo educacional almejaram dar visibilidade ao sistema de ensino sob a lógica da Diretoria da Instrução Pública, algumas vezes "celebrando" os feitos do governo na área educacional (CATANI, 1994).

A realização da perspectiva histórica comparada das festas, Brasil - Portugal, foi beneficiada pela concessão da bolsa de doutorado-sanduíche pela CAPES (Coordenação de Aperfeiçoamento de Pessoal de Nível Superior) durante o período de seis meses, entre março e agosto de 2010, para a realização das atividades de pesquisa na Universidade de Lisboa, sob a orientação do Professor Dr. Jorge Ramos do Ó. Nesse período, tive a oportunidade de realizar diversas leituras, discuti-las em reuniões individuais com o coorientador junto ao grupo de estudos realizados todas as terçasfeiras, dirigido por este. Além disso, coletei informações relevantes para o empreendimento do estudo comparado das instituições escolares em acervos da cidade, como foi acima indicado. Nestes locais compilei documentos acerca das festas em contextos diferenciados, das comemorações específicas da escola, da história da educação e de outras áreas de estudo, tais como a sociologia e a antropologia. Os

\footnotetext{
${ }^{21}$ Apesar desse periódico ter circulado até 1937, nesse estudo restringimos sua análise até a data de 1926.
} 
materiais analisados para esse fim constituíram-se de teses e dissertações produzidas não somente na área de história da educação, mas em outros campos de estudo (Sociologia, Etnografia e Antropologia, por exemplo), bem como manuais de ensino e periódicos educacionais produzidos no período histórico compreendido nesta investigação, 1890 a 1930.

\section{- Periódicos de ensino portugueses:}

A escola: Revista de Pedagogia e de Instrução Pública, 1890: foi um jornal criado por iniciativa de professores e do diretor, Henrique Freire, com a mudança do grupo de docentes para Évora, sua publicação foi interrompida em Lisboa e retomada na nova localidade. Tratou-se de um periódico típico do final do século XIX, mantendo, no entanto, uma feição crítica e reivindicatória, decorrente da defesa de uma 'instrução primária e pública' como estratégia de progresso e da valorização do professor, considerada condição essencial para o êxito dessa estratégia. "Periódico premiado com a medalha de ouro na Exposição Internacional Partonopea permanente de Nápoles" e "10 prêmio na Exposição Pedagógica do Porto de 1890", são as distinções que A Escola destaca no seu cabeçalho, confirmando a qualidade e o equilíbrio formal que caracterizaram a fonte.

No quadro de defesa do professorado, A Escola noticiou os movimentos da classe e participou dos esforços de constituição de uma 'federação primária'. A atenção concedida às conferências pedagógicas inseriu-se, de algum modo, nesta preocupação de destacar os espaços de consolidação de uma cultura profissional no seio do professorado (NóvoA, 1993, p. 367-368).

Revista Infantil, 1911-1928: foi um periódico destinado à professores e alunos, que poderiam também contribuir com a publicação enviando desenhos, textos, histórias, etc. A tônica dominante da Revista Infantil incidiu na formação moral e cívica das crianças. Era ilustrada com fotografias, textos em prosa e em verso, cujo teor educativo e moralizante assumia a forma de notas biográficas de educadores e pedagogos portugueses e estrangeiros; contos, histórias e poemas, fundamentalmente de autores portugueses; máximas e 'pensamentos' ('Bons conselhos', 'Conselhos Amigos', 'Para ler e meditar', etc.).

Os textos de caráter instrutivo abordaram temas como a higiene, a física, a zoologia, a agricultura etc., sendo dominante a preocupação em desenvolver nas crianças o amor pela natureza e pelos animais. Com relação à componente recreativa, promovia concursos literários e de advinhas, passatempos, enigmas e anedotas, além de danças, jogos, canções, hinos e o teatro infantil (NóVOA, 1993, p. 801).

O Magistério - Semanário Pedagógico, 1914 - 1916: "Semanário defensor dos interesses do corpo docente, $O$ Magistério deu grande relevo aos congressos de professores, publicando as suas teses, discussões e conclusões". Além disso, trouxe 
análises acerca dos problemas da classe, dos métodos pedagógicos, dos programas escolares e das reformas educativas. Ao lado destes núcleos centrais, o Semanário apresentou ainda as habituais rubricas de legislação e notas oficiais, de necrologia, de 'conhecimentos úteis', de consultas e de divulgação bibliográfica, literária, científica e artística; bem como textos de análise gramatical (NóvOA, 1993, p. 350).

Revista Escolar, 1921-1935: os propósitos deste periódico, de acordo com os seus editores, foram: propugnar um completo e melhor ensino popular, a mais perfeita preparação do professorado, uma 'inteligente' propaganda pró-escola, apresentar questões pedagógicas e trazer os seus leitores a par do avanço da escola no mundo. (PAssos, 1921). Foi uma publicação cujo intuito central assentou-se na divulgação de idéias e práticas educativas, legitimadas por um corpo de conhecimentos das áreas da psicologia e pedagogia com o intuito de reorganizar a educação portuguesa numa base científica moderna (NóvOA, 1993, p. 796). A ideia de modernização das escolas surgiu em Portugal na década de 1920, associada à outra que era a da regeneração urgente da Pátria; para isso, seria necessário fomentar a educação popular e reformar o sistema de ensino. Após estes primeiros debates, a revista se aperfeiçoou e pode-se perceber uma filosofia e orientação educativa alinhada com o pensamento pedagógico internacional, com especial relevo para as experiências realizadas em países considerados 'desenvolvidos', tais como Suíça, a França e a Bélgica. Esta divulgação pedagógica realizou-se por meio da apresentação de diferentes sistemas educativos, de experiências escolares e, principalmente, de metodologias de ensino. Em todo o período, a revista privilegiou o movimento educativo mundial, especialmente as discussões sobre a Escola Nova.

A Escola Primária - 1927-1939: Órgão da Liga Internacional da Educação Nova em Portugal (entre 1932 e 1934), foi um periódico destinado aos professores primários, que publicou ao longo da sua existência artigos sobre 'ensino em geral' (sistema educativo, pedagogia, didática, métodos, etc) e abordou, nos primeiros anos, as questões profissionais relacionadas ao associativismo, ao estatuto docente, à carreira e aos vencimentos dos professores, entre outras. Foi dirigida por homens que lideraram a corrente católica e conservadora da União do Professorado Primário que, posteriormente, em 1927, foram nomeados pela ditadura Portuguesa de Salazar para integrarem uma espécie de comissão administrativa. Apresentou intervenções dos vários responsáveis pelo Ministério da Educação relativas à política educativa; comentários acerca da situação do ensino em Portugal; legislação sobre o ensino; artigos e traduções de natureza teórico-pedagógica; comparações e menções a outros sistemas de ensino; notas necrológicas e homenagens a vários professores; referências à congressos; informações sobre exames e critérios de seleção de inspetores escolares; denuncias sobre o analfabetismo e propostas para solucionar este problema; artigos sobre a história e a importância da União dos Professores Primários; artigos, balanços e relatórios de contas referentes ao movimento associativo; comentários e análise da imprensa pedagógica e associativa da época (nacional e estrangeira); artigos 
pedagógico-didáticos; artigos de natureza didático-curricular; apreciações sobre o estado, normas e irregularidades dos edifícios escolares; análises e publicações de excertos sobre manuais de ensino primários e alguns textos sobre a educação de deficientes (NóvoA, 1993).

- Manuais pedagógicos brasileiros:

AGUAYO, A. M. Didática da escola nova. Penna \& Ávila (tradução). Biblioteca Pedagógica Brasileira, Atualidades Pedagógicas, Série III, Vol. XV. São Paulo: Companhia Editora Nacional, 1935.

TOLEDO, João (Assistente técnico do ensino do Estado de S. Paulo). Escola Brasileira (Desenvolvimento do programa de pedagogia em vigor nas escolas normaes). São Paulo: Livraria Liberdade, $3^{a}$. ed. (revista e ampliada), 1932.

NÉRICI, Imídeo Giuseppe. Introdução à Didática Geral (Dinâmica da Escola). Brasil/Portugal: Editora Fundo de Cultura, 1960.

SILVA, Ruth Ivoty Torres da (Auxiliar técnico do Centro de Pesquisas e Orientação Educacionais da Secretaria de Educação e Cultura do Rio Grande do Sul). A escola primária rural. Rio de Janeiro/Porto Alegre/ São Paulo: Editora Globo, 2a edição, 1957.

MATTOS, Luiz Alves de (Catedrático de Didática Geral e Especial e diretor do Colégio de Aplicação da Faculdade Nacional de Filosofia da Universidade do Brasil). Sumário de Didática Geral. Rio de Janeiro: Gráfica Editora Aurora, $3^{\text {a }}$ edição, 1960.

- Manuais de ensino portugueses:

AFFREIXO, José Maria da Graça, FREIRE, Henrique (coords.). Elementos de Pedagogia para servirem de guia aos candidatos ao Magistério Primário. Lisboa: Livraria Ferreira, $4^{\mathrm{a}}$ edição, 1875.

PLANCHARD, Émile (professor extraordinário da Universidade de Coimbra, doutor em Ciências Pedagógicas. A Pedagogia Escolar contemporânea - Bases Orientações - Aspectos. Coimbra: Coimbra Editora Ltda., 1942.

LOUREIRO, Francisco de Sousa (Professor efetivo dos liceus e Diretor da Escola do Magistério Primário de Coimbra). Lições de Pedagogia e Didática Geral. Edição do Autor, 1950. 
VIANA, Mario Gonçalves. Pedagogia Geral. Porto: Livraria Figueirinhas, $4^{\mathrm{a}}$ edição, 1960, 1ª edição 1946.

LAGE, Bernardino da Fonseca. Didáctica Geral da Escola Moderna Segundo os atuais programas das Escolas do Magistério Primário. Porto: Edição de J. Reis \& Silvas, Ltda., 1945.

COELHO, J. Augusto. Noções de Pedagogia Elementar, coordenadas, em harmonia com o programa oficial, para uso dos alunos das escolas normais e de habilitação para o magistério primário. Liboa: Livraria Moderna - Editora, 1903.

COELHO, F. Adolpho. Questões Pedagógicas II - O plano geral do ensino público. Separata de “O Instituto”, vol. 58. Coimbra: Imprensa da Universidade, 1911.

A partir da seleção dos materiais discriminados, nosso intuito foi perseguir as primeiras iniciativas, os primeiros discursos, teorias e representações, que contribuíram para disseminação da prática festiva escolar; mesmo considerando a dificuldade para se indicar com exatidão a data de criação desta prática, foi possível fixar, numa escala temporal, certos momentos privilegiados, entre as décadas de 1890 e 1930. Essas análises estão comentadas e organizadas nos seguintes capítulos: Capítulo 1: Desvelando as peças da máquina festiva: um estudo genealógico das comemorações, que discute, a partir da proposta de investigação genealógica de Foucault (2005), a proveniência das festas escolares, recorrendo-se para isso, aos estudos de antropólogos, sociólogos, etnógrafos e historiadores, a partir dos quais intentou-se identificar os elementos que compuseram o objeto em diferentes contextos e como eles foram reajustados para os objetivos educacionais; no Capítulo 2, intitulado No palco da festa: as comemorações escolares nos discursos e nas práticas educativas renovadas, apresenta-se o arcabouço teórico, principalmente construído pelos pedagogos representantes da Escola Nova, que serviram para forjar a prática das festas nas instituições de ensino como possibilidade de aprendizagem para, em seguida, perscrutar como tais justificativas ressoaram nas práticas dos alunos das escolas primárias portuguesas e brasileiras na viragem do século XIX para o XX; denominado De como montar a "máquina" festiva: os saberes e os fazeres educacionais associados às festas, o capítulo 3 dedica-se às análises dos materiais, especialmente os manuais e os periódicos de ensino, que deram suporte aos saberes dos professores para os fazeres comemorativos; percebe-se que, se realizada da forma como esteve descrita nos textos teóricos e prescritivos, as comemorações poderiam ter influências marcantes na 
construção da identidade dos professores e nas suas práticas; A máquina festiva a serviço das escolas brasileiras e portuguesas: os seus diferentes tipos, usos e funções é o título do capítulo 4, no qual apresentam-se algumas categorias analíticas que pretenderam organizar sob temáticas, em alguns casos comuns aos dois países, em outros não, as principais modalidades festivas localizadas no corpus documental, organizados em modalidades como recitativos, número corais, pequenas representações teatrais e, por fim, as "grandes solenidades", as ocasiões festivas constituem-se observatórios relevantes das movimentações no campo educacional. A partir da construção dessas categorias é possível identificar as proximidades e distanciamentos entre as festas escolares realizadas nessas duas realidades. Por último, nas Considerações Finais pretende-se a recuperação do percurso da pesquisa e a proposição de novas possibilidades de estudo do tema aos investigadores da história da educação. 


\section{Capítulo 1: Desvelando as peças da máquina festiva: um estudo genealógico das comemorações}

... que maravilhoso campo de observação é a festa para o historiador: momento de verdade em que um grupo ou uma coletividade projeta simbolicamente sua representação de mundo, e até filtra metaforicamente todas as suas tensões (VOVELLE, 2004, p. 247).

Alegria, divertimento, confraternização, dança e música foram todas expressões que, de forma mais ou menos intensa, estiveram associadas à idealização festiva em diferentes contextos sociais e históricos. Entretanto, como se pode depreender a partir de leituras de textos de áreas distintas, nem sempre as festas estiveram associadas a tais impressões. É possível perceber, a partir de uma análise mais cuidadosa desse objeto de estudo - a festa ${ }^{22}$ - propósitos e funções distintas das idéias originalmente associadas ao evento. Como nos faz imaginar Ozouf (1976), a festa pode ser considerada uma maquinaria que, organizada de forma específica, serve a diferentes funções, conforme o campo e o contexto histórico. Cabe, então, nos perguntar: quais são os elementos que compõem essas "máquinas festivas"? Quais foram seus usos e funções em diferentes períodos da história da humanidade? E para as instituições de ensino, quais foram as solenidades escolares? Quais elementos provenientes de antigas festas realizadas pelos povos primitivos ${ }^{23}$ permaneceram nas festas escolares do século XIX e $\mathrm{XX}$ ?

Considerando-se as questões apresentadas a pretensão desse capítulo é ${ }^{24}$ a de explorar os diversos significados atribuídos ao fenômeno e objeto festas, não somente a partir de trabalhos da área historiográfica, mas também de contribuições de distintas áreas. Acredita-se que tal comparação permitirá compreender os detalhes dos elementos que compuseram as "máquinas festivas", seus usos e funções em diversos contextos

\footnotetext{
${ }^{22}$ As comemorações foram objetos de estudo privilegiados em diferentes campos de investigação e puderam ser reconhecidas e legitimadas a partir do movimento dos Annales no século XX, que buscou em um primeiro momento, uma renovação dos temas de pesquisa no âmbito historiográfico, para depois engendrar metodologias mais apropriadas à investigação dessas questões inéditas.

23 A escolha do termo povos primitivos neste trabalho foi feita a partir das leituras de autores como Duvignoud (1983) e Durkheim (1996) que o utiliza em seus estudos. Hoje, sabe-se que tal uso é objeto de discussões e controvérsias no âmbito da antropologia.

${ }^{24}$ Preferiu-se, neste capítulo, a utilização dos verbos no presente, já que as possibilidades de estudo apresentadas extrapolam os momentos das suas produções, permitindo úteis reflexões sobre o tema em pesquisas contemporâneas.
} 
sociais e históricos e as reminiscências desses no ambiente escolar, construindo assim, um das possíveis histórias das comemorações escolares.

Sabe-se que a escrita da história é constituída não somente de narrativas que se autodenominam oficiais, mas também de interpretações, desejos, equívocos e contradições que, ao serem comparados, nos permitem uma compreensão maior do objeto em estudo. A partir destas narrativas procura-se elucidar o que pode ser considerado o ato de festejar? O que é a festa? Para que se festeja? Qual a sua função nos diferentes tipos de contextos históricos e sociais? A pretensão deste trabalho não é o de esgotar a possibilidade de escrita de uma história das festas escolares, mas indicar uma das perspectivas possíveis a partir de um estudo histórico comparado, e com fundamentação em um corpus previamente definido, indicando a sua potencialidade reveladora de uma história. De acordo com Corbin (2005) "Há, com efeito, objetos históricos de tamanhos diversos, e, entre eles, objetos muito pequenos, portadores "de uma forte carga de urânio": potência de irradiação, de revelação" (p. 27).

Ao recuarmos no tempo e no espaço, é possível reconhecer nas referências históricas acerca das festas, sentidos específicos associados à socialização, à demarcação do espaço social, às confraternizações, aos ensinamentos, à transmissão cultural, às religiões, às instituições sociais, aos rituais e a ressignificação do mundo. As incursões pelos trabalhos de pesquisadores de diferentes áreas como a História Geral, a Antropologia, a Sociologia e a Etnologia são muito férteis para a compreensão do que denominamos neste trabalho como "festas em geral", acontecidas na sociedade em diversos campos, ou ainda, dos "mecanismos festivos", que compuseram os eventos comemorativos e que os tornaram tão eficazes para diferentes propósitos no decorrer do tempo em sociedades distintas.

Esta pesquisa desenvolve-se no sentido de desvelar em um primeiro momento, os elementos que compõe as festividades, para depois verificar, a partir das suas composições distintas, as suas variadas funções. Propõe-se, desse modo, que o estudo das comemorações aqui levado a efeito aproxime-se mais de um tratamento epistemológico do objeto, do que político (BourdiEU, 2010). A análise histórica permite decompor o objeto em seus elementos constitutivos, demonstrando como estes elementos vão surgindo uns após os outros, situando-os no conjunto de circunstâncias que os originou e determinando as causas que os suscitaram, neste sentido, conforme assinala Durkheim (1996): 
Toda vez, portanto, que empreendemos explicar uma coisa humana, tomada num momento determinado do tempo - quer se trate de uma crença religiosa, de uma regra moral, de um preceito jurídico, de uma técnica estética ou de um regime econômico - , é preciso começar por remontar à sua forma mais simples e primitiva, procurar explicar os caracteres através dos quais ela se define nesse período de sua existência, fazendo ver, depois, de que maneira ela gradativamente se desenvolveu e complicou, de que maneira tornou-se o que é no momento considerado (DURKHEIM, 1996, p. VIII).

Tratou-se de empreender a genealogia das festas escolares, desvendar a sua proveniência, dando a conhecer os elementos que as compõem e que as caracterizam enquanto tal, assim como assinalou Foucault (2005). O significado do termo genealogia é retomado pelo autor de forma distinta da definição original que associa o conceito ao estudo das origens. Para Foucault (2005), a genealogia, por meio do estudo das proveniências, que será desenvolvido adiante, busca assinalar as singularidades dos acontecimentos, observá-los de um ângulo novo, nunca observado, reencontrar seus diversos papéis, definir suas lacunas, mostrar o que não ocorreu. Deixa-se de lado a história linear, ordenada e evolutiva dos acontecimentos históricos para perceber, a partir desse momento, o que existe por detrás de cada objeto, quais elementos o compõe, quais suas incongruências e rupturas, e como ele se articula às escolhas de cada pesquisador.

O estudo das festas, na perspectiva genealógica, almeja identificar desde povos antepassados elementos que as compuseram e as identificaram enquanto tal, definir o que convém entender por festa, indicar os sinais exteriores perceptíveis que as caracterizam, reconhecer as festas onde quer que se encontrem e que impedem que confundamos com outros fenômenos da vida social, já que as festas só podem ser definidas em função das características que se encontram em todos os lugares onde houver festa, bem como relacioná-la a momentos específicos de ruptura ou de continuidade da vida social (DURKHEIM, 1996). As comemorações analisadas neste capítulo foram escolhidas com o intuito de identificar em diferentes contextos sociais e históricos como o objeto festa se constituiu e quais foram as funções assumidas pelos atos comemorativos nos diversos campos sociais. Parte-se do pressuposto de que, muito mais do que um ato aleatório e despretensioso, as festas tiveram um lugar importante na definição das estruturas sociais, institucionais e de poderes.

A abordagem genealógica abre novas possibilidades para o estudo historiográfico antes baseado somente na história dos grandes acontecimentos, dos 
heróis e personalidades ilustres. Dessa abordagem, todos os temas e objetos são relevantes e não possuem uma hierarquia prévia; por este motivo, nada lhe deve escapar. A renovação da perspectiva historiográfica é seguida da inovação dos métodos; o trabalho do genealogista exige a minúcia do saber e o acúmulo de muitos materiais, além de muita paciência. A genealogia assim entendida não almeja construir "monumentos ciclópicos", mas perceber as "pequenas verdades inaparentes, estabelecidas por um método severo" (FOUCAULT, 2005, p. 260), apreender nas fontes selecionadas as tensões, as rupturas e contradições da questão da pesquisa. Desfaz-se a ilusão de que, ao localizarmos a origem, encontraríamos o nosso objeto puro, em seu estado de perfeição: a sua verdade. No caso do nosso objeto de estudo, volta-se às fontes para compreender que não existe a origem das festas como um acontecimento perfeito ou verdadeiro, mas a composição irregular do objeto nas suas distintas nuances. A festa é constituída de contradições, erros, equívocos, sobreposições de elementos derivados de distintas comunidades e dos diferentes usos que dela fizeram os indivíduos que as pensaram e festejaram. Elaborar a genealogia de uma questão não será, portanto, buscar a sua 'origem',

negligenciando como inacessíveis todos os episódios da história; será, ao contrário, deter-se nas meticulosidades e nos acasos dos começos; prestar uma atenção escrupulosa em sua derrisória maldade; esperar para vê-los surgir, máscaras finalmente retiradas, com o rosto do outro; não ter pudor de ir buscá-los lá onde eles estão, 'escavando as profundezas'; dar-lhes tempo para retornarem do labirinto onde nenhuma verdade jamais os manteve sob sua proteção (FOUCAULT, 2005, p. 264).

Elaborar a genealogia de um objeto de pesquisa é buscar a proveniência entendida como a antiga pertença a um grupo - o do sangue, da tradição, o que liga aquelas da mesma altura ou da mesma baixeza. A proveniência permite reencontrar, "sob o aspecto único de uma característica ou de um conceito, a proliferação dos acontecimentos através dos quais (graças aos quais, contra os quais) eles se formaram" (Foucault, 2005, p. 265). Compreender a proveniência é perceber o que se passou na dispersão que lhe é própria, é situar os acidentes e os ínfimos desvios, as completas inversões, os erros, as falhas, os cálculos errôneos; é descobrir na raiz do que conhecemos e do que somos, que não há a verdade e o ser, mas a "exterioridade do acidente" (FOUCAULT, 2005).

A investigação da proveniência não funda, muito pelo contrário: ela agita o que antes se percebia como imóvel, fragmenta o que se 
pensava unificado; mostra a heterogeneidade do que se imaginava conforme a si mesmo (idem, p. 266).

No estudo da proveniência faz-se relevante observar a emergência concebida como o ponto de surgimento, que se produz a partir de um determinado estado de forças, que podem dar origem a ideias, coisas e temas, conforme compreendido por Foucault (2005). A emergência é a entrada em cena das forças, designa um lugar de confrontação, "enquanto a proveniência designa a qualidade de um instinto, sua intensidade ou seu desfalecimento e a marca que ele deixa em um corpo..." (FOUCAULT, 2005, p. 269). São justamente o conjunto de forças em movimento e possivelmente antagônicas que manterão as festas vivas em seus múltiplos usos e funções; serão, enfim, os elementos que a compõe, que permitirão sua constante reinvenção. Momentos de confrontação, rupturas e indeterminações fazem parte da história das diferentes populações, e não foi diferente nos contextos selecionados para este estudo: a consolidação do regime político republicano em Portugal e no Brasil apresenta-se um período de incertezas e de disputas de forças antagônicas que lutaram por um projeto político e no âmbito deste para o estabelecimento de um calendário civil de festas comuns em face do novo regime.

Ao pensar a emergência da festa, no sentido proposto por Foucault (2005), é possível associá-la a um desejo de instaurar um ato coletivo, caracterizado pelo extraordinário, o extratemporal e o extralógico. A festa, na sua emergência, constitui outro mundo, outra forma de experienciar a vida social marcada pelo lúdico, pela exaltação dos sentidos e das emoções. A festa não é apenas boa para dela se participar, mas também para pensá-la e refletir sobre os fundamentos do vínculo coletivo; enfim, o que a faz parte da sociedade (PEREZ, 2002, p.19). Em determinados contextos, como no Brasil, a festa configura-se como um "potente mecanismo de operação de ligações" (idem, p. 35). Neste sentido, não importa se a festa é religiosa ou profana, o que vale é compreendê-la como o espaço privilegiado de reunião das diferenças, espaço de figurações sociais, de ligações, de assembléia coletiva e de sociabilidade, é na festa que o grupo reanima periodicamente o sentimento que tem de si mesmos e de sua unidade, ao mesmo tempo que os indivíduos são revigorados em sua natureza de seres sociais (DURKHEIM, 1996).

Antes de tratarmos dos trabalhos que investigaram o tema "festas em geral", faz-se importante discutir a definição de festa. Duvignoud (1983) defende a tese de que 
não podemos atribuir a todas as festas o mesmo significado e que as autênticas festas realizadas para e por uma população só poderiam ser localizadas entre os povos primitivos, constitutivas dos indivíduos cujos dramas e teatralização, chamados nas ocasiões festivas, permitiam a própria composição da coletividade, capaz de se organizar e se manifestar nestes eventos. Os principais papéis sociais de um grupo, tradicional ou não, são apresentados, compostos e significados em suas funções fundamentais no decorrer das festas primitivas. $\mathrm{O}$ verdadeiro sentido ou significado da festa só pode, na argumentação de Duvignoud (1983), ser reconhecido entre e pelos povos primitivos; nas palavras desse autor, as nossas sociedades industriais não conheceriam verdadeiramente a festa, ou não reconheceriam seu significado inicial.

A música pouco variava, porém da repetição dos mesmos sons e desta curta melodia, repisada fastidiosamente, nascia uma excitação a que ficaram sensíveis todos os assistentes. Eles de mexiam também, trocavam sorrisos furtivos e cúmplices, como se estivessem debaixo do olhar de um senhor e comunicassem, entre si, um segredo que o governante não deveria compreender (DUVIGNOUD, 1983, p. 83).

A cerimônia social torna-se o elemento fundamental da vida coletiva porque exprime com intensidade as dimensões dos papéis sociais e o confronto dos símbolos que eles significam, tornando-se, assim, por si só, um ponto de reparo e um referencial no dinamismo da vida social, correspondendo “... a estes momentos de ruptura e de subversão e que, por isso, não tem duração" (idem, p. 230). As características assinaladas por Duvignoud (1983) acerca da importância das cerimônias coletivas para a determinação dos papéis sociais e do simbolismo como expressão das concepções de mundo de um determinado povo são corroboradas por Durkheim (1996) no estudo das formas religiosas consideradas primitivas. Para Durkheim (1996) não pode haver sociedade que não tenha a necessidade de manter e revigorar, em intervalos regulares, os sentimentos coletivos e as idéias coletivas que fazem sua unidade e personalidade. Essa restauração moral é obtida por meio de reuniões, assembléias, congregações, nas quais os indivíduos aproximando-se uns dos outros, reafirmam em comum seus sentimentos (DURKHEIM, 1996, p. 472). Tem-se nestas concepções o primeiro elemento definidor das situações festivas: o seu potencial de unificar e identificar uma determinada sociedade sob signos e referenciais sociais comuns.

$\mathrm{Na}$ teatralização da festa, a propósito dos rituais primitivos, os sentidos, o visual, o toque, o odor e a cinestesia são postos a serviço da coletividade, cada indivíduo tem o seu papel e sabe executá-lo com presteza. Seus personagens, 
disfarçados, representam uma oportunidade, uma possibilidade de mudança ou de confirmação da ordem das coisas ou do mundo. É ainda por meio das festas que os povos primitivos confirmam os sistemas de classificação de um grupo ou de uma civilização por meio das suas dramatizações, das repetições e aplicações de determinados rituais que, ao mesmo tempo em que remetem a um passado conhecido e seguro, garantindo ao novo membro a entrada em uma determinada comunidade, selecionam, na incorporação de novos elementos, as possibilidades para o futuro (Duvignoud, 1983). Os rituais servem, portanto, para manter a vitalidade das crenças, para impedir que elas se apaguem das memórias, para revivificar os elementos mais essenciais da consciência coletiva (DURKHEIM, 1996), penetrando na consciência de cada indivíduo o seu lugar e responsabilidade na comunidade. A festa tem um momento definido para o seu início, uma data, uma estação, um fato, mas seus efeitos prolongamse nas memórias para além do ato celebrativo: e este é um dos elementos que fazem da festa um mecanismo tão significativo e poderoso.

As possibilidades de homogeneização de interesses e de conformação de papéis sociais presentes nas festas definidas como primitivas se vêem ameaçadas por outra importante característica das celebrações, que é a sua subversão. As festas, ao serem tomadas como momentos de "subversão exaltantes", permitem a transformação do tempo ou até mesmo a sua supressão, a transformação da rotina e do espaço que, mesmo conhecido, passa a ser reapropriado: "ela é capaz de cortar uma seqüência, quebrar o encadeamento dos acontecimentos que a ideologia histórica dominante nos apresenta como lógico e insuperável" (DUVIGNOUD, 1983, p. 24-25). Concebida nesta perspectiva, a festa emerge como ato surpreendente e imprevisível, se declarando tanto durante as cerimônias rituais com as quais não se confunde, quanto ao longo de toda manifestação pública (idem, p. 31-32), ou nas palavras de Ozouf (1976), a circunstância decide a festa e a improvisação a completa. A festa, ao mesmo tempo em que sistematiza a ordem da natureza, identifica uma determinada forma religiosa e uma comunidade e restaura um passado unificador, ela também possibilita a ruptura, a criação de algo novo, o improviso e a subversão.

A festa estimula o homem na sua capacidade singular de inventar e de imaginar, de usar disfarces para investir contra a eterna resistência do mundo ou, em outros termos, no seu potencial catártico (DEL PRIORE, 2000). Como exemplo, Duvignoud (1983) apresenta as festas relacionadas à natureza da população Pueblo, quando o saber presente (a pobreza dos habitantes das aldeias Pueblo e camponeses na 
expectativa de uma eventual boa colheita) e o saber implícito (a regulamentação do cosmo) confundem-se em um determinado estado de consciência que a psicologia não consegue explicar; percebe-se, então, que em diferentes ciências, existe algo na festa que escapará às regulamentações, as hierarquias e aos espaços sociais.

Os sistemas de classificação e as representações coletivas presentes nas festas não são redutíveis a equações matemáticas ou linguísticas; por isso, não basta descrevêlas ou delimitar a sua conformação ou estrutura; é preciso pensá-las como virtualidades, tanto nos seus atos praticáveis, quanto nas sugestões que ultrapassam a consciência real por uma consciência possível. Os signos tradicionais utilizados (emblemas, danças, músicas, teatros, improvisos) denotam a distância que se estabelece entre o que é, e o que deveria ser e "a vinculação de todos estes signos a uma mitologia que regressa ao passado, a uma situação definitivamente estabelecida in illo tempore" (DUVIGNOUD, 1983, p. 99). A festa retoma o passado em um "conhecimento que identifica a diferença pela sua assimilação a algo já experimentado e alguma forma tomada por empréstimo, mecanismo que reencontramos em todas as sociedades" (idem, ibidem). As lembranças que os fazem reviver e das quais eles se sentem solidários dão-lhes uma impressão de força e de confiança: as pessoas ficam mais seguras em sua fé e identidade "quando vêem a que passado longínquo ela remonta e os grandes feitos que inspirou. É esse caráter da cerimônia que a torna instrutiva" (DURKHEIM, 1996, p. 409).

Enquanto elemento constitutivo de uma determinada cultura, a festa é também ritual de entrada do novo membro à determinada comunidade. Nestes rituais, o jovem deve "reencontrar antigos vestígios" e colocar "os pés sobre as pegadas dos seus predecessores" (idem, p. 100). A festa também contribui para a não dissolução da cultura da qual é proveniente, e a entrada na vida deve ser uma capitulação frente à cultura estabelecida; a festa torna-se, assim, uma das experiências sociais que tem condições de organizar a realidade confusa e que é capaz de dar sentido às coisas abstratas.

Para além das associações recorrentes entre festa e as expressões de alegria, entusiasmo, novidade, confraternização e liberdade, é relevante perceber, a partir dos estudos citados, a potencialidade ritualística de conformação e instauração das festas sociais. As festas, nas suas variantes, são capazes de definir hierarquias e posições sociais; concretizar conceitos abstratos; retomar a cultura; indicar representações sociais legítimas a serem incorporadas; permitir uma nova compreensão do tempo (o calendário escolar, por exemplo) e do espaço social (as instituições escolares, por exemplo); são 
potentes mecanismos de congregação e instauração do coletivo. Na sua reminiscência conhecida e segura (comprovada na história), vislumbram as mudanças para o futuro (projetos). É um tempo/espaço privilegiado de reunião das diferenças, de composição das figurações sociais, de assembléia coletiva e de sociabilidade que, ao mesmo tempo em que conformam, estimulam o homem na sua capacidade de inventar, de imaginar e de usar disfarces para investir contra a resistência do mundo.

Assim que cumprimos nossos deveres rituais, retornamos à vida profana com mais coragem e ardor, não somente porque nos pusemos em contanto com uma fonte superior de energia, mas também porque nossas forças se revigoraram ao viver, por alguns instantes, uma vida menos tensa, mais agradável e mais livre (DURKHEIM, 1996, p. 417).

A investigação aqui proposta, a partir do que assinala Duvignoud (1983) acerca das verdadeiras festas primitivas, compreende as comemorações realizadas em outros contextos considerados civilizados, as suas distintas funções como herdeiras das festividades primitivas, cujos elementos constitutivos se repetiram em celebrações realizadas em outros momentos sociais e históricos. Os elementos aí envolvidos, tais como a música, a dança, o estabelecimento do coletivo, bem como a inserção e ruptura social dessas festas originais que se repetem, a inversão ou manutenção das hierarquias sociais, a criação ou destruição de imaginários coletivos ${ }^{25}$, constituem os componentes que, na sua recorrência, caracterizarão os eventos festivos ulteriores.

$\mathrm{Na}$ busca das peças que compõem o mecanismo festivo ganham destaque, além das festas primitivas, as solenidades com funções religiosas, cujos elementos serão, posteriormente, tomados de empréstimo em vários outros tipos de comemorações, como as festas escolares, por exemplo, objeto de nossa análise. Trata-se de elementos que, transmutados, podem ser visualizados tanto em uma quanto em outra; são os mesmos componentes constitutivos da festa que se transformam para atender propósitos diferentes. Como exemplo dessas relações, pode-se comparar a festa religiosa e a escolar, nas quais estão presentes alguns rituais que transmutados se repetem, como: os sermões pregados pelos sacerdotes nos dias dedicados aos santos são substituídos pelos discursos dos reformadores da instrução, as fantasias são transformadas em uniformes escolares com o objetivo de garantir a ordem e disseminar uma ideia de homogeneidade escolar, as procissões transformadas em passeatas garantem que mesmo aqueles que estivessem em suas casas pudessem acompanhar o festejo, as músicas e encenações

\footnotetext{
${ }^{25}$ As discussões sobre a constituição de um imaginário social e escolar podem ser lidas respectivamente em OLIVEIRA (1989) e SOUSA (1998).
} 
(não só relacionadas à religião católica, mas às outras religiões também) deixam de possuir um conteúdo religioso para divulgarem ensinamentos cívicos; os cânticos religiosos, que se transformam em músicas e hinos cívicos e patrióticos, bem como a participação popular que, tanto para uma quanto para outra festa, tornam-se imprescindíveis para o sucesso destas.

As festas, nas diferentes religiões, possuem significados bastante peculiares que merecem ser comentados detidamente. Nas sociedades cristãs feudais, a festa foi apresentada como uma recompensa, pois, no final da vida, Jesus estaria no céu nos esperando para uma grande solenidade; ou seja, a comemoração surgia contraposta aos momentos difíceis de atribulações e contrariedades que deveriam ser vividos para chegar-se aos céus. $\mathrm{O}$ momento anterior à morte das pessoas também era digno de um ritual cuidadoso. Nas antigas casas religiosas, a enfermaria era uma espécie de "peneira", um local de espera daqueles que iriam se recuperar ou morrer; neste último caso, era a "entrada num outro mundo". O enfermo era permanentemente velado e, em situações específicas, acompanhado por outros irmãos, para as confissões, recitações religiosas, ou liturgias.

Ninguém morria sozinho: morrer era um ato menos privado do que quase todos os outros. Em volta do agonizante, como na sociedade profana para as núpcias, organizava-se uma espécie de festa, onde a convivialidade atingia a sua plenitude (ARIÈS E DUBY, 1990, p. 6566).

O encontro dos religiosos, as rezas e os rituais coletivos, tornavam-se, assim, momentos festivos, que passavam a ser caracterizados não mais pela alegria, mas pela possibilidade de convívio e de troca entre os de mesma crença. A sociabilidade constitui-se, desse modo, o elemento definidor do conceito festa nestas situações. Estas trocas e estes convívios eram também importantes para as festas nas casas profanas. No século XI, por exemplo, era dever do pater familias casar, procriar e levar a sua comunidade a crescer, cada vez mais, atraindo e 'retendo' comensais. A festa governava a economia doméstica e tornava-se ocasião importante para a definição dos espaços e papéis sociais, celebração do acúmulo de riquezas, de congregação dos amigos e de garantia da segurança dos seus:

(...) era nula a intenção de investir, e se tinham o cuidado de acumular reservas no quarto, no celeiro, na cave, era apenas na previsão das festas em que as riquezas da casa seriam alegremente gastas. (...) $\mathrm{O}$ senhor, no entanto, empregava-os também de boa vontade para comporem divertimentos, textos falados, cantados em língua vulgar, encenados, que eles sabiam que lhes iriam valer, mais do que os 
sermões edificantes, o reconhecimento dos 'amigos': (...) Velava por que sua casa estivesse bem provida de mulheres para todo o serviço, o guarda-roupa fornecido de 'vestes', como se dizia, suficientes para as distribuições rituais, nas grandes festas (ARIÈS E DUBY, 1990, p.8182).

A própria arquitetura das casas e a organização das salas previam a realização destes encontros. As salas eram equipadas especialmente para os festins; seu mobiliário, formado por uma ou duas mesas e alguns bancos ou tamboretes, elementos de base dos quais algumas salas eram completamente destituídas. Juntavam-se ainda algumas baixelas, provisões e "alguns objetos díspares (um tabuleiro de jogo, um livro de contas ...)" (ARIÈS E DUBY, 1990, p. 189). Esta disposição deveria representar a ordem, o poder e a ostentação necessários para a apresentação dos lugares ocupados socialmente. $\mathrm{O}$ recurso ao cerimonial era utilizado com recorrência como instrumento de disciplina, necessários ao senhor para manter a ordem da sociedade doméstica; era uma forma de afastar a raiva, os ciúmes, a cobiça e os rancores e "aquecer sem tréguas 'a amizade"” (idem, 1990, p. 87).

O conde e a condessa, o par dominante, ocupavam o centro do espetáculo, objetos de honra particular, servidos pelos mais elevados servidores; mais perto deles, quase ao seu nível, o senescal, que tinha direito, tal como o senhor, (...). E uma vez que se tratava de exibição pública, de demonstração de poder, importava que os oficiais da mesa fossem cavaleiros; recebiam o mesmo equipamento, a mesma paga que os companheiros de armas do senhor (...) (ARIÈS E DUBY, 1990, p. $86)$.

Assim como o mobiliário, os utensílios, os espaços organizativos da casa e as vestimentas utilizadas, também se constituíam elementos de distinção social nas ocasiões festivas. De acordo com alguns estudiosos (ARIÈs E DUBY, 1990), a ocasião festiva contribuiu de maneira decisiva para o desenvolvimento da moda nos séculos XIV e XV; rapazes e moças gostavam de se vestir bem para mostrarem-se uns aos outros nas ocasiões públicas, não é sem sentido, que se identificava nas famílias ocasiões para o uso de roupas comuns e de festa:

A moda é também a festa. Ricos ou menos ricos, todos estes jovens são a isca que de imediato ateia a perspectiva de festas e de justas, e bem se deixam seduzir por todos os festejos que um pouco por toda a parte constantemente se organizam, na Toscana, em Génova e talvez sobretudo na Venécia... (ARIÈS E DUBY, 1990, p. 246).

Ao lado das profissões, títulos, sobrenomes e heranças, as festas também contribuem para a demarcação dos espaços sociais, bem como para a diferenciação 
entre o espaço público e o privado. Os momentos das festas (Natal, Páscoa ou Pentecostes, festas nupciais ou luto de alguém) eram o da apresentação, do reconhecimento social (mostrava-se algo aceitável e aprovável socialmente) que se contrapunha ao termo privado e seus derivados, que evocava o que era familiar e mais restrito $^{26}$. Percebe-se, desse modo, que a festa na Idade Média esteve associada a distintos momentos da vida dos indivíduos, demarcando-os, separando-os e enfatizando suas transições; festejava-se para socializar desde o nascimento até o luto de um membro da sociedade. As celebrações transitavam entre os dois âmbitos privado e público e entre o profano e o sagrado.

Entre os séculos XVI e XVII, as festas religiosas católicas, principalmente para defender-se dos ataques dos reformadores protestantes e atender as tomadas de posição doutrinais do Concílio de Trento foram ressignificadas. Os elementos centrais que as constituíam permaneceram (hinos, procissões, rituais); entretanto, existiu um maior controle e sistematização dos mesmos. A ênfase foi colocada na devoção individual e na assistência obrigatória à missa aos domingos e dias santos; na missa, as pessoas elaboravam as suas preces individuais e conviviam com outros fiéis e religiosos; os fiéis rezavam, ouviam a homilia e os anúncios de festas, jejuns e ofícios da semana. Naquele período, a grande atenção dada à vida espiritual dos indivíduos convoca-os a participarem de vários rituais da Igreja; um "bom cristão" não deveria se contentar com apenas uma confissão por ano e uma única comunhão na festa da Páscoa (ARIÈs E DuBY, 1990, p. 83), mas sim, participar de todas "as cerimônias que traduziriam a sua pertença à comunidade da paróquia e à comunidade invisível da Igreja universal" (idem, ibidem); ou seja, as festas religiosas possuíam um duplo papel: inserir o indivíduo na vida religiosa e social.

Além de instituir individualmente a vida social e espiritual dos fiéis, as festas religiosas realizadas por ocasião dos Dias de Santos (aniversário de vida e/ou de morte dos santos cristãos) também se constituíram manifestações de piedade coletiva. Os agrupamentos deste tipo eram, ao mesmo tempo, grandes festas populares nas quais se homenageava o santo indicado, mas também se bebia, jogava e dançava desde o cair da noite; desse modo, acontecia uma "evasão para um outro tipo de religião, a do extraordinário e do irracional, no quadro de uma comunhão popular onde se confundem

26 Cabe destacar que por ocasião dos rituais nupciais, em todas as casas grandes ou pequenas, a hospitalidade festiva era tão grande que atingia, não poucas vezes, a dissolução entre o público e o privado (ARIÈS E DUBY, 1990), fazendo com que a comunidade participasse da intimidade do casal. 
citadinos e rurais, ricos e pobres, homens e mulheres" (ARIÈs E DUBY, 1990, p. 95). Eram justamente estes comportamentos que os homens da Igreja se esforçavam para disciplinar e, suprimir determinados abusos, como a crença "mágica nos poderes taumatúrgicos do Santo, precipitação em clamar por milagre, desvio da festa religiosa em favor de divertimentos profanos" (idem, ibidem), que eram repreensíveis por si só e extremamente escandalosos num dia santificado.

Este rigorismo do tribunal das consciências assenta na condenação de tudo o que procede da sociabilidade festiva ou lúdica que escapa ao clero. O baile, as 'assembléias', as 'peregrinações' bretãs, o cabaret, os serões da aldeia, a boda de núpcias, os ritos da convivência juvenil e até a simples galantaria que revela o orgulho do corpo suscitam as iras desses párocos sombrios (ARIÈS E DUBY, 1990, vol. 4, p. 508).

A situação festiva, como momento específico para fomentar a sociabilidade de determinadas comunidades, torna-se estratégia de poder dominante no controle destes elos sociais. As normas e as regras acerca da organização das celebrações profanas ou religiosas tornar-se-iam objeto de luta pelo poder: quem indicaria as datas a serem celebradas? Como deveria transcorrer o dia festivo? Qual o ritual legítimo? Estas e outras questões indicam que as manifestações festivas não poderiam mais acontecer de forma aleatória como expressão da total liberdade e alegria dos indivíduos como aconteceram com nossos antepassados, mas a partir deste momento somente em situações determinadas, em locais combinados com antecedência e por meio de um ritual legitimado institucionalmente, neste primeiro tempo, pela Igreja católica. Identificam-se, dessa forma, as primeiras transformações que são realizadas na estrutura e nas funções do maquinário festa e que serão retomadas nas comemorações escolares dos séculos XIX e XX.

Ao lado da dança, da música, da alegria e das homenagens, outra atividade relevante no estudo das comemorações e que ganharam destaque no contexto de institucionalização do modelo escolar de ensino a partir do século XIX foi a leitura de livros; inicialmente com a Bíblia, interpretada pelos religiosos autorizados e, em outras comemorações, com os romances de cavalaria. A festa tornou-se, então, uma ocasião profícua para a disseminação dos livros e da cultura letrada. Esta ocasião, que remetia quase sempre para outro espaço-tempo mais prazeroso, era coletiva e presente desde a sociabilidade do convívio, passando pela intimidade familiar e doméstica e chegando até a individual.

No tempo das colheitas muitos ceifeiros (segadores) vêm reunir-se aqui nos dias de festa, e entre eles há sempre um que sabe ler e que 
pega num desses livros, e então somos mais de trinta à volta dele e ficamos à escutá-lo com tanto prazer que nos faz desaparecer mil cabelos brancos (ARIÈs E DUBY, 1990, p. 155).

Ainda no âmbito das expressões religiosas, faz-se relevante identificar as diferenças entre as comemorações realizadas pelas diferentes formas de religião. Apesar de todo o esforço da religião católica para prescrever os dias festivos e os rituais celebrativos, as festas levadas a efeito pelas religiões indígena e negra, especialmente no contexto social brasileiro, merecem destaque por inaugurarem uma nova função, novos temas e novos rituais para os eventos festivos. As religiões afrobrasileiras, compostas de mesclas entre os elementos religiosos que sobreviveram, apesar das condições adversas de vida dos escravos africanos e indígenas, retiram da religiosidade católica a sua exclusividade pela organização das comemorações religiosas e criam seus próprios rituais com elementos distintivos: sacrifícios, rituais (podendo ou não haver incorporação de espíritos) e, principalmente, a dança.

Tal acontecimento não é apenas um episódio social, ritual, comunitário e cíclico, com sua função organizativa para as comunidades, mas aponta para algo maior, sendo ligado a um significado superior ao que aparece; ele é o ápice de proximidade, para estas religiões, entre o humano e o sagrado. De acordo com Berkenbrock (2002), essa é justamente a característica que define os fundamentos da festa religiosa: ela se faz por causa do encontro, está no centro da verdade religiosa, nela o esperado acontece, o professado não é mais a fé, é realidade. Neste sentido, as distintas formas religiosas concordam, é através da festa que se transforma em verdade aquilo que a religião propõe, "é a festa que faz a religião" (BERKENBROCK, 2002, p.218). É possível identificar traços comuns entre as religiões e as festas, como por exemplo, a existência de uma coletividade celebrante, a unanimidade, a independência com respeito aos indivíduos, a coerção e a manutenção da lembrança (DURKHEIM, 1996).

Todas as religiões ligam o culto à festa. A fé é o ato de amor e o amor se expressa na alegria do encontro com a pessoa amada. A festa é como um êxtase de amor. Toda verdadeira festa tem algo de místico porque celebra a vida (BARROS, 2002, p.64).

As relações entre as festividades organizadas pela religião católica e por outras religiões não podem ser definidas somente nas suas divergências; assim como acontece no catolicismo, a organização do ano nas comunidades afrobrasileiras é definida por intermédio dos eventos festivos. As festas instauram uma organização temporal que definem as atividades dos terreiros; desse modo, são os esteios de referência para a 
organização do tempo, a partir do ponto de vista religioso. A fixação do calendário com as datas festivas, que diferem de terreiro para terreiro, tem como origem a combinação do calendário africano e do cristão-católico. Além disso, cada festa em si, possui uma organização e uma especificidade, sendo que outras festas, ao saírem dos ambientes religiosos para ganharem o grande público, tornam-se parte da cultura brasileira (BERKENBROCK, 2002). O ritmo da vida acompanhava o ciclo das festas, fossem elas profanas ou religiosas, que permitiam um descanso do trabalho cotidiano, e a catarse das dificuldades vividas, mesmo que não fosse esse, o seu propósito.

As festas, assim como a religião e as demais instituições humanas, apresentam um certo ciclo de vida. Elas nascem com a intenção de fazer reviver, na lembrança dos povos, suas vitórias e esperanças. Têm um certo período de vida útil, no qual presta-se à intenção original. Com o decorrer do tempo, corre o risco de tornar-se instrumento de dominação, ao criar falsas legitimações da ordem vigente (LOPES JÚNIOR, 1999, p. 37).

As festas religiosas, antes realizadas no recôndito dos mosteiros e casas religiosas, com funções de convívio e troca entre os religiosos, ao se transportarem para outros espaços sociais, ganham elementos profanos a serem destacados. Se antes se tratavam de oportunidades para instaurar uma coletividade celebrante, a unanimidade e a manutenção da lembrança, ao penetrarem outros espaços sociais, as festas tornam-se, além disso, momentos de libertação de comportamentos e sentimentos, de ruptura da rotina vivenciada, que pode ser constatado no uso exagerado das bebidas por alguns indivíduos, das danças não autorizadas e das músicas profanas celebradas. Esses usos não autorizados das ocasiões festivas pretendem instaurar momentos de expressão do grupo e até mesmo de resistência às condições opressoras ou até mesmo de profecia de um futuro distinto e distante. A situação festiva possibilita ao povo oprimido se organizar e, mesmo em circunstâncias de escravidão e de vida terrível, encontrar forças de resistência e de expressão da sua dignidade humana, aproximando-se, desta forma, também das festas realizadas pela cultura indígena ou negra (BARROS, 2002).

A saída das festas dos seus locais originais permite, além da sua transformação em demonstração de resistência, que elas se incorporem a outros elementos da cultura de um povo, como, por exemplo, o folclore brasileiro, concebido como reminiscências de fenômenos religiosos (DuRKHEIM, 1996), no caso das festas da Umbanda e do Candomblé. Entre as mais conhecidas mundialmente pode-se citar a Festa de São 
Cosme e Damião ${ }^{27}$, a lavagem das escadarias de Nosso Senhor do Bonfim ${ }^{28}$, a passagem de ano, bem como as festas conhecidas e praticadas mais regionalmente, como o reisado ou a congada ${ }^{29}$ (BERKENBROCK, 2002). Estes elementos festivos que se autonomizam e extrapolam o momento específico da comemoração fazem com que o estudo deste objeto não se restrinja a um campo específico, nem a uma situação única, mas permite que a festa seja reproduzida para diferentes fins e que seu fascínio dissemine-se além do seu lugar original, constituindo-se, até mesmo, um elemento definidor da identidade de um povo.

As festas religiosas e a sua transformação em folclore popular constituíram objetos de estudo relevantes no âmbito sociológico é só poderia ser completamente compreendido com o auxílio deste. O fato folclórico passa a ser concebido como algo maior do que um simples folguedo popular, pois, por detrás dele, estão vivos e presentes os modos mais simbolicamente profundos através dos quais as pessoas procuram estabelecer formas rituais de comunicação entre si e com os seus deuses e santos: "está também presente aí uma das formas que a sociedade encontra para reescrever e traduzir, através da festa e do folguedo, o peso de sua ordem e também o de suas contradições" (BRANDÃO, 1978, p.10). A análise do folclore deve procurar realizar a leitura de seus rituais e redescobrir nos modos como o povo se organiza para cultuar os seus padroeiros, os sinais de sua própria identidade, ele permite, para além das religiões conhecidas, uma maior autonomia popular para a sua organização de acordo com as condições locais (DURKHEIM, 1996).

A rede de relações entre participantes da Festa transporta para um campo de atuações simbólicas uma estrutura de modos de participação igual à da sociedade, aquela que ela organiza para produzir os seus bens e reproduzir as relações entre seus produtores sociais (BRANDÃO, 1978, p.60).

Alguns rituais, inclusive as festas, teriam, desse modo, duas contribuições inerentes à vida dos indivíduos: uma exterior, capaz de organizar os espaços sociais, revertendo o peso de sua ordem e amenizando suas incoerências, e outra interior,

\footnotetext{
${ }^{27}$ Festa celebrada pela Igreja Católica anualmente na data de 26 de setembro para homenagear os gêmeos médicos e milagreiros.

${ }^{28}$ A tradicional Lavagem do Bonfim, de caráter afro-religioso ocorre na quinta-feira que antecede o Dia de Reis da religião católica. O ritual realiza-se com a lavagem com vassouras e água de cheiro das escadarias e do átrio da Igreja do Nosso Senhor do Bonfim.

${ }^{29}$ O Reisado é uma representação popular em homenagem aos Reis Magos ou Santos Reis. Já o congado é uma manifestação cultural e religiosa de influência africana celebrada em algumas regiões do Brasil. Trata basicamente de três temas em seu enredo: a vida de São Benedito, o encontro de Nossa Senhora do Rosário submergida nas águas e a representação da luta de Carlos Magno contra as invasões mouras.
} 
colaborando com a constituição das identidades de cada população. No caso brasileiro, a organização dos carnavais será defendida por alguns autores (DAMATTA, 1990; BRANDÃO, 1978; AMARAL, 1998) como o elemento diferenciador da sociedade. O domínio do ritual, presente na festa de Carnaval brasileiro, é apresentado como uma região privilegiada para se penetrar no "coração cultural" de uma sociedade, na sua ideologia dominante e no seu sistema de valores. O ritual constitui-se um domínio privilegiado para manifestar aquilo que se deseja perene ou mesmo eterno o que nos coloca um problema de contrastes,

(...) daí a necessidade absoluta de estudar o mundo social tomando como ponto de partida as relações entre seus momentos mais importantes: o mundo cotidiano e as festas; a rotina e o ritual; a vida e o sonho; a personagem real e o paradigma (DAMATTA, 1990, p.31).

O mundo dos rituais é relativo ao que ocorre no cotidiano, e só pode ser definido por meio de uma dialética entre o cotidiano e o extraordinário; estando numa situação extraordinária, se constitui pela abertura desse mundo especial para a coletividade: "não há sociedade sem uma idéia de um mundo extraordinário, onde habitam deuses e onde, em geral, a vida transcorre num plano de plenitude, abastança e liberdade" (DAMATTA, 1990, p.33). O carnaval é o rito ${ }^{30}$ privilegiado por DaMatta (1990) no trabalho citado, encontrando-se junto daquelas instituições perpétuas que nos permitem sentir, mais do que abstratamente conceber, nossa própria continuidade enquanto grupo e nossa identidade enquanto nação. É no carnaval, que nós, brasileiros,

deixamos de lado nossa sociedade hierarquizada e repressiva, e ensaiamos viver com mais liberdade e individualidade. Essa é, para mim, a dramatização que permite englobar numa só teoria, não só os conflitos de classe (que são compensados e abrandados no Carnaval), como também a invenção de um momento especial que, guarda com o cotidiano brasileiro uma relação altamente significativa e politicamente carregada (DAMATTA, 1990, p.34).

Neste sentido, faz-se relevante destacar a diferença entre as funções ditas "oficiais" das festas e os diferentes "usos" que os indivíduos delas faziam, conforme já se explicitou. No caso brasileiro, Mary Del Priore (2000) explicou, não somente as formas pelas quais as festas foram descritas nos documentos oficiais, mas também

\footnotetext{
${ }^{30}$ De acordo com Durkheim (1996), os ritos são concebidos como maneiras de agir que só surgem no interior de grupos coordenados e se destinam a suscitar, manter ou refazer alguns estados mentais desses grupos. Eles expressam alguma necessidade humana, seja individual ou social, podendo servir a vários fins, produzir efeitos semelhantes e até mesmo se substituir.
} 
outras funções implícitas das comemorações ${ }^{31}$. A festa concebida como expressão teatral de uma organização social, de um fato político, religioso ou simbólico vai disseminar de forma mais ou menos explícita, mais ou menos oficial, quem detinha o poder que, no período colonial da história do Brasil, estava dividido entre a Igreja e o Estado. Em outras palavras, a função oficial da festa, naquele contexto, foi afirmar a perenidade das instituições de poder; contudo, existem indicações de que não foi exatamente dessa forma que o evento foi apropriado pelos diferentes indivíduos.

Se por um lado observam-se as instituições tentando dar uma única função à festa, por outro vamos perceber o povo dela se apropriando de maneira peculiar. A festa, seus espaços e suas atividades vão ter outra interpretação aos olhos da multidão, a cada momento possibilitando uma inversão na sua utilização (DEL PRIORE, 2000, p.105).

A presença do Estado português nas cerimônias públicas da Colônia almejou marcar a sua assiduidade no território, além de construir as relações entre os diversos grupos sociais e a própria metrópole. No Brasil Colônia, bispos, governadores-gerais e vice-reis foram homenageados em grandes ritos, assim como as dias importantes da vida dos governantes (casamentos, nascimentos e mortes), em um ritual que destacou o reconhecimento do poder real e da burocracia que o representou nestas terras. Já as festas religiosas, que aconteceram durante todo o período colonial brasileiro estudado por Del Priore (2000), tiveram sua importância potencializada após o Concílio de Trento (1545 a 1563), que confirmou o investimento catequético e pastoral das festas. Para isso, foram elaboradas várias publicações especializadas, de maneira a orientar o clero na organização e realização das festas do calendário eclesiástico (DEL PRIORE, 2000).

No âmbito educacional, as festas a serem realizadas pelos padres-mestres e pelos alunos, a partir do século XVI, estavam previstas no documento Ratio Studiorum dos educadores jesuítas. Neste documento, as festas estavam intrinsecamente relacionadas à religiosidade cristã e orientaram várias atividades escolares dos jesuítas, como a organização dos dias de aulas, os conteúdos escolares, os feriados e festas escolares. Os dias feriados deveriam ser organizados em cada escola "de acordo com o costume do lugar" e com o calendário religioso cristão. No caso de coincidir duas festas na mesma semana, o feriado regular semanal dos alunos era abolido, bem como a

\footnotetext{
${ }^{31}$ Uma análise antropológica das festas no período colonial pode ser encontrada em Magalhães (2002). Neste estudo, a autora analisa o lugar e o significado da festa na vida social do período colonial brasileiro, comparando dois tipos de festas: a Festa do Divino e a Festa do Despotismo.
} 
atividade escolar que acontecia uma vez por semana das disputas de conhecimentos entre os alunos. Em algumas solenidades era prevista a distribuição de "modestos" prêmios aos melhores alunos, desde que tal ato não causasse algum detrimento moral e intelectual. A exposição de trabalhos escolares, como a poesia, era orientada pelo professor de retórica que de dois em dois meses deveria fazê-la como forma de reconhecimento dos trabalhos escolares melhor desenvolvidos. Por fim, anualmente, em todos os anos deveria ser realizada a Festa de Nossa Senhora ou do Santo Patrono, com grande pompa de orações, poesias, versos afixados à parede, variedade de emblemas e insígnias, determinada pelo Reitor do Colégio ${ }^{32}$. O modelo escolar dos jesuítas vigorou durante três seculos em diferentes países do mundo, com exceção dos dias dos feriados, que eram flexíveis e poderiam ser organizadas de acordo com os costumes do lugar, as indicações dos dias de festa religiosa e do que deveria acontecer nestes dias era bastante específica e pode ser percebida durante um longo período da história. Determinava-se, nestas prescrições religiosas, duas práticas que seriam recorrentes nas festas organizadas pelas escolas graduadas, a exposição dos trabalhos dos alunos nas situações de festa e a distribuição de prêmios aos melhores alunos.

As instituições de poder, durante o período colonial brasileiro, buscaram normatizar as festas e, por intermédio delas, a população. Foi o meio pelo qual se tentou impor regras e normas às comunidades existentes à época. As leis e regras, segundo a autora, almejaram esvaziar a função catártica da festa e dar um significado único para cada evento. No entanto, contra todas as regras que a Igreja e o Estado tentaram impor, as celebrações esboçaram um trajeto feito de múltiplas funções: a festa também podia servir como um "exutório para suportar as árduas condições de vida das classes subalternas na Colônia” (DEL PRIORE, 2000, p. 90), uma pausa para a rotina fatigante ou um momento no qual os grupos sociais podiam exaltar suas posições e valores, seus privilégios e poderes, demonstrando nas festas públicas seu lugar na cidade e na sociedade política, e até mesmo ocasiões para a realização de disputas e revanches entre as famílias ou comunidades, bem como de reivindicações dos vários grupos que compunham a sociedade.

\footnotetext{
${ }^{32}$ http://www.histedbr.fae.unicamp.br/navegando/fontes_escritas/1_Jesuitico/ratio\%20studiorum.htm, acesso em 02/01/2012.
} 
Um ritual expressivo da consolidação do poder em territórios colonizados foram as cerimônias de posse ${ }^{33}$, cujo objetivo definia-se em função do poder ocupado, foram comuns entre outros povos europeus, especialmente os espanhóis, franceses, holandeses e ingleses, além dos portugueses. O cerimonial dos diferentes povos europeus, ao mesclarem rituais religiosos (missas e colocação de cruzes, por exemplo) e políticos (leitura de discursos, tratados e documentos), almejou por meio dessas cerimônias deixar bem claro e patente aos povos colonizados, os novos contratos de posse das terras descobertas e dos desígnios espirituais; ou seja, quem deveria cuidar e administrar as novas terras e a vida dos indivíduos com a chegada das novas populações.

O domínio colonial sobre o Novo Mundo foi instaurado por meio de práticas basicamente cerimoniais - os colonizadores fincaram cruzes, estandartes, bandeiras e brasões; marcharam em procissões, apanharam um torrão do solo, mediram as estrelas, desenharam mapas, proferiram algumas palavras ou permaneceram em silêncio (SEED, 1999, p. 10).

Os rituais diferiam entre os povos europeus, mas possuíam como objetivo comum buscar o entendimento, a percepção e a adesão dos povos indígenas e negros aos novos costumes, formas de organização e cultura da população recém-chegada. Os signos e protocolos escolhidos almejaram a transmissão de uma mensagem específica sobre "quem seria o novo dono da terra", além da compreensão desta mesma mensagem pelos povos submetidos; esses signos e protocolos eram considerados a maneira mais eficaz de se transmitir uma mensagem e de se fazer compreender uma ideia a uma população cujos códigos linguísticos eram ignorados e desconhecidos. Destacou-se, assim como aconteceu com as festas escolares, um papel pedagógico das cerimônias de posse do "novo mundo".

Os colonizadores europeus se apoiavam em entendimentos sobre os modos pelos quais a autoridade política legítima deveria ser instaurada; esses entendimentos poderiam ser ditados por uma autoridade formal, ou conseguidos baseando-se em um consenso implícito. Cada código legal definia o significado da posse, do domínio da

\footnotetext{
${ }^{33}$ Para SEED (1999), as cerimônias devem ser compreendidas como um conjunto de signos, rituais e práticas capazes de transmitir uma mensagem acordada por uma população para outra. Entretanto, para cada população europeia dos séculos XVI e XVII investigada pela autora, nos prevalece uma definição de cerimônia. Em inglês, português, espanhol e holandês, o termo trazia conotações levemente pejorativas de constrangimento e afetação, significava uma formalidade vazia, um gesto simples ou uma pequena cortesia. Já para os franceses, à palavra cerimônia poderiam ser atribuídos vários significados distintos, como veremos adiante.
} 
soberania e autoridade real. As cerimônias simbólicas de posse tinham como primeiro alvo os conterrâneos europeus, seus compatriotas e líderes políticos, e não precipuamente os povos indígenas. Não existia interesse e nem curiosidade entre os europeus para conhecer ou legitimar as práticas de posse da nação concorrente; os mesmos fatores que faziam com que cada sociedade avaliasse como válidas suas práticas culturais e legais, concorriam para que os métodos de outras nações fossem percebidos como incompreensíveis ou simplesmente irrelevantes (SEED, 1999); o objetivo era deixar bem patente para os povos sobrepujados quem detinha o poder.

Os ingleses, por exemplo, demonstravam sua autoridade e posse sobre a nova localidade empregando objetos arquitetônicos e iniciando atividades agrícolas cotidianas; este povo acreditava que fixar objetos imóveis tais como cercas, casas e jardins, veiculava de forma transparente direitos de posse, e que as ações de agricultura ordinária confirmavam seu privilégio exclusivo. Os espanhóis possuíam um discurso ritualizado dirigido aos nativos, exigindo sua submissão à Coroa católica da Espanha; este procedimento especificava um texto que deveria ser lido diante de nativos reunidos. Os portugueses reivindicavam sua posse em relação ao Novo Mundo baseando-se nos seus direitos de 'descoberta'; suas realizações tecnológicas que permitiam a descoberta do Novo Mundo lhes garantiam o direito de posse. Os holandeses descreviam por escrito e criavam mapas dos novos sítios recém-descobertos. Aos elementos políticos descritos, mesclavam-se outros religiosos, ou seja, a dominação de um território não se fazia sem o consentimento destes últimos. Rezar uma missa, colocar uma cruz e entoar hinos religiosos, foram elementos que se repetiram para as distintas cerimônias dos povos europeus no Novo Mundo. A cerimônia era assim constituída de uma parte profana, ocasião importante para a definição dos espaços e papéis sociais, celebração do acúmulo de riquezas, de congregação e de garantia da segurança dos seus, e de uma parte religiosa, cujo ritual recuperado servia de legitimação aos atos coercitivos praticados contra a população nativa.

Dentre as cerimônias descritas por Patrícia Seed (1999) em seu livro Cerimônias de Posse na Conquista Europeia do Novo Mundo (1492-1640), destacam-se as realizadas pelos franceses, que pareceram ser os mais cuidadosos com todo o ritual que envolvia este tipo de solenidade. O ritual iniciava-se com o consentimento dos nativos, organizando-se uma procissão para a colocação de uma cruz; para esta atividade específica observava-se o requinte na roupa, com trajes especiais (túnicas azul-turquesa com a flor-de-lis, camisas azuis com cruzes brancas), na música (cantos 
sagrados), nos acessórios (turíbulos, crucifixos, castiçais) e na organização das pessoas da procissão por posição social. O ponto culminante do ritual de posse do pedaço de terra seria o momento visualmente dramático em que ergueriam a cruz, rodeados por muitos membros de tribos indígenas (SEED, 1999, p. 65).

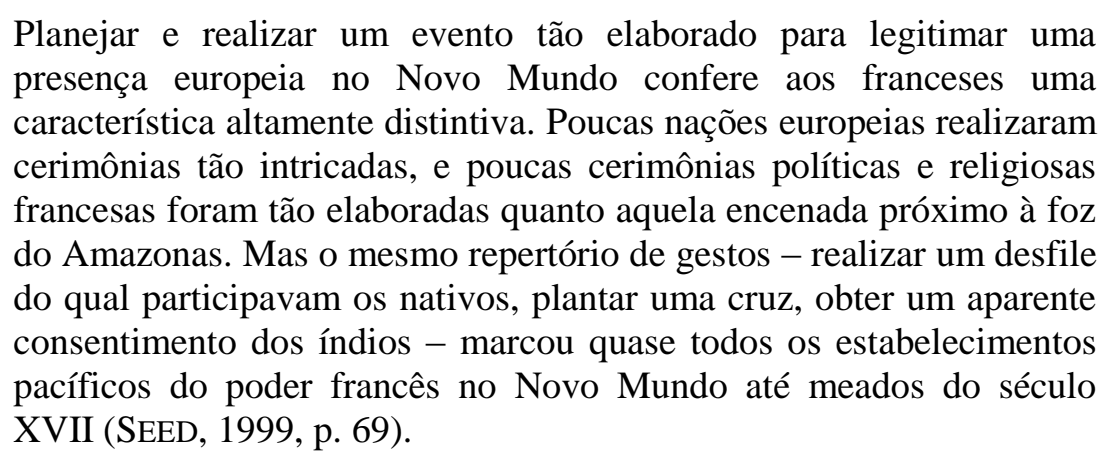

Os franceses acreditavam que o conjunto diferente de ações - procissões, fixação de cruzes e a encenação de ritos teatrais, veiculava o direito de posse de forma indelével; os motivos para as características cerimoniais da posse francesa estiveram enraizadas na sua tradição política e no significado "singularmente francês da palavra cerimônia"34. A festa francesa, ao contrário das que aconteciam entre os povos primitivos descritos por Duvignoud (1983), buscava regulamentar e regularizar tudo o que deveria acontecer, todos os passos e todas as danças; as músicas eram escolhidas e determinadas previamente, não deixando espaço para a espontaneidade característica das manifestações festivas dos povos antepassados. A determinação de regras é a diferença que existirá entre a festa 'verdadeira' e a festa ideológica, como define Duvignoud (1983). A partir do momento em que a festa passa a ser regulamentada e regulada nas suas manifestações, segundo Duvignoud (1983), ela torna-se ideológica.

Nas festas, de uma forma geral, a ordem vigente tanto pode ser reproduzida como invertida, dependendo do grau de poder que o povo detém em tais situações. Por estar inserida numa lógica sociocultural, a festa é o momento de expressão de carências, aspirações e disputas pelo poder. Essas tensões produzem novas sínteses de sentido, capazes de reinterpretar os símbolos já utilizados nas festas. Tais sínteses de sentido não são puras, mas se apresentam continuamente ameaçadas e contaminadas, e se constroem na medida em que o povo reconhece e assume a contradição social. Percebe-se, desta

\footnotetext{
34 Para os franceses, à palavra cerimônia poderiam ser atribuídos quatro significados distintos: o primeiro deles é procissão; proferir a palavra cerimônia implicava um desfile ou procissão; outro significado referia-se às roupas utilizadas na realização do evento; um terceiro sentido significava ordem. Neste caso, os detalhes e cuidados com as regras, música, procissão, vestes e acessórios estavam longe de constituir uma trivialidade.
} 
forma, uma contradição nas festas populares, que ora pode legitimar a ordem dominante, ora pode promover a reorganização social a partir dos dominados (RIBEIRO JÚNIOR, 1982).

As festas ocupam um espaço privilegiado da nossa cultura, adquirindo significados particulares, "tendo sido, desde o período colonial, um fator constitutivo de relações e modos de ação e comportamento, ela é uma das linguagens favoritas do povo brasileiro" (AMARAL, 1998, p. 07). Nas festas ${ }^{35}$ são traduzidas muitas experiências da população, além de expectativas de futuro e imagens sociais: "é capaz de, conforme o contexto, diluir, cristalizar, celebrar, ironizar, ritualizar ou sacralizar a experiência social particular dos grupos que a realizam" (AMARAL, 1998, p.07-08). Além disso, constituiu-se um modo de se resolver, no plano simbólico, algumas das contradições da vida social, podendo até mesmo ser considerada uma dimensão de aprendizado da cidadania e apropriação de sua história por parte do povo, contrariando a idéia de alienação que a envolve. Sendo assim, a festa, longe de se tornar um fenômeno de distanciamento da realidade, é uma forma de estabelecer a mediação entre a utopia e a ação transformadora; para a organização desses eventos, muitos grupos sociais se organizaram em nível local e puderam até mesmo crescer política e economicamente. Por meio deles, a festa se transformou, neste caso, em uma instituição oficial.

O potencial pedagógico implícito e não formal das festas do povo, de acordo com Ribeiro Júnior (1982), estaria na reelaboração efetuada das suas vivências, história, utopia e opressão, de forma tão ou mais competente que outras agências, que usam métodos mais formalizados, como por exemplo, a escola. Enfim, nas festas, o arbitrário cultural dominante é avaliado, ridicularizado e pode até mesmo ser invertido: "a festa será uma ação pedagógica tanto mais tradicional quanto mais conseguir manifestar, recuperar, sintetizar um capital cultural que faz parte do repertório de experiências do povo” (RIBEIRO JÚNIOR, 1982, p.43). Convém assinalar também que

A festa é uma forma ritual, tradicional, de inculcação dos princípios pedagógicos elaborados pela cultura do povo e que formam um 'habitus-de-ser-povo'. Este é reforçado através de uma pedagogia implícita que mais vive do que tematiza seus princípios. A festa é uma verdadeira ação pedagógica, que integra sanções, autoridade e um modo específico de inculcação (RIBEIRO JUNIOR, 1982, p.43).

\footnotetext{
35 Rita Amaral (1998) trata em sua tese de doutorado das seguintes festas nacionais brasileiras: Oktoberfest, de Blumenau (Santa Catarina); de Nossa Senhora da Achiropita (realizada no Brás, bairro popular de São Paulo); do Peão de Boiadeiro, em Barretos, no Estado de São Paulo; da festa de São João e do Boi-Bumbá, de Parintins, no Amazonas; das festas do Divino Espírito Santo e do Círio de Nazaré, em Belém, Estado do Pará.
} 
Como divulgadora de um capital cultural e definidora de um habitus ${ }^{36}$, a festa popular, assim como a comemoração escolar define para uma determinada população uma cultura a ser preservada e um modo de ser e de se comportar aceitos socialmente. A ação pedagógica da festa popular fica evidente de duas formas privilegiadas, primeiro em um ritual definido como "festa-para-o-povo", em que este comparece como multidão, sendo-lhe reservado um papel passivo: "nessas ocasiões sua cultura é pasteurizada, são pinçados apenas elementos exóticos” (RIBEIRO JÚNIOR, 1982, p. 43) para serem divulgados e legitimados; segundo, pode ser uma "festa-do-povo", na qual o povo é dono de sua festa e nela se expressa livremente, trabalhando sua condição de oprimido e vislumbrando "possibilidades de uma vida que ainda não existe" (RIBEIRO JÚNIOR, 1982, p.43). Nas festas ocorridas nas instituições escolares as duas situações são identificadas, percebe-se que elas eram comemorações elaboradas pela escola para a população, quando de sua participação passiva como observadora do ritual, e $d a$ população, a partir do momento em que ela apreende ativamente os sentidos e significados atribuídos a cada ocasião festiva, bem como a cultura específica da escola.

Considerando a possibilidade de subversão inerente aos eventos do povo, as celebrações de eventos sociais ou religiosos não podem ser percebidas somente como momentos de confirmação da ordem, da identificação do poder, do esquadrinhamento do espaço, dos ensinamentos e de conformação social. Em diferentes contextos históricos, os momentos festivos foram utilizados pela população como ocasiões para extravasar as repressões e os abusos sofridos, para inverter a ordem dominante e para demonstrar os diversos pequenos poderes (familiares, profissionais, políticos, sociais). Os usos e funções não previstos ou almejados pelos promotores das festas deveriam, então, ser considerados como uma ameaça ao objetivo previsto e, por isso, reprimida. Dessa forma, nos estudos acerca das comemorações nos diferentes espaços sociais fazse relevante atentar aos comportamentos individuais, aos corpos constituintes da festa e as possibilidades de transgressões à ordem estabelecida.

Para as diferentes faixas etárias, as comemorações representam significados distintos. No caso dos jovens, é nas festas e nos jogos, que eles encontram os meios

\footnotetext{
36 Os conceitos de capital cultural e habitus são retomados de Pierre Bourdieu (2001). De acordo com o sociólogo, o capital cultural pode existir sob três formas: no estado incorporado, no estado objetivado e no estado institucionalizado, para o nosso estudo, destacamos o estado incorporado apresentado nas diferentes formas de disposições duráveis nos indivíduos e tendo como principais elementos constitutivos os gostos, o domínio maior ou menor da língua culta e de informações sobre o mundo escolar. O conceito de habitus é definido Bourdieu $(1986 ; 2010)$ consta em nota da introdução dessa tese.
} 
propícios à sua afirmação e integração social; nestas atividades lúdicas, eles têm ocasião de se mostrarem fortes, honrados e valentes, qualidades prestigiadas e que os ajudam a satisfazer o seu desejo de participação social. A possibilidade de instrução dos jovens e adultos pelo meio indireto da festa pública foi assinalada ainda no século XVIII em uma proposta de organização da instrução pública francesa elaborada por Condorcet (2008), sob o título Cinco Memórias sobre a Instrução Pública ${ }^{37}$ que serviu de inspiração para a elaboração do Relatório e projeto de decreto sobre a organização geral da instrução pública. Em suas memórias Condorcet, fixou o quadro teórico e ideológico que conduziu a elaboração da proposta de decreto para a organização do sistema público, gratuito, laico e universal de instrução nacional, desde o ensino primário até o ensino superior. Tal documento tornar-se-ia leitura obrigatória dos planos de educação nacional dos países do Ocidente entre os séculos XIX e XX (Вото, 2011, p. 04).

Na memória dedicada à instrução comum para os homens, Condorcet (2008) indicou aspectos importantes a serem considerados no uso das festas públicas como possibilidade de instrução e de formação dos indivíduos que não tinham acesso às escolas, religiosas ou não. Inicialmente, o poder público deveria cuidar da regularização das comemorações existentes em uma determinada localidade, minimizando e até suprimindo as influências que as instituições religiosas teriam nessas solenidades. As que já existiam, independente do poder público, deveriam ser apropriadas pelo mesmo com o objetivo de impedir que as festas contrariassem seus objetivos políticos. Eram úteis quando utilizadas como meios para lembrar fortemente as épocas de prestígio mundial do país, para alimentar e estimular na população "o entusiasmo e os sentimentos generosos da liberdade, da independência, da dedicação à pátria; enfim, para gravar nos espíritos um pequeno número desses princípios que formam a moral das nações e a política dos homens livres" (CONDORCET, 2008, p. 191). Tudo nessas festas deveria inspirar a liberdade, o sentimento de humanidade, o amor pela pátria; com o cuidado de não deixar multiplicar o seu número, seria difícil conseguir para essas festas o nome imponente de festas públicas. As comemorações públicas poderiam ser organizadas em dias regulares de festas nacionais e ainda em festas particulares:

\footnotetext{
${ }^{37}$ Traduzida por Maria das Graças de Souza e publicada pela Editora Unesp no ano de 2008, o texto original foi inicialmente publicado em partes, durante o ano de 1791, em quatro números consecutivos de um jornal intitulado Biblioteca do Homem Público, e que se destinava a apresentar aos leitores análises de obras, tanto francesas quanto estrangeiras, sobre política em geral, legislação e direito (CONDORCET, 2008, p. 08).
} 
Haveria festas gerais e festas particulares. Uma cidade, cujos cidadãos se tivessem distinguido numa ocasião memorável, consagraria seu aniversário com uma festa. A nação celebraria aquelas nas quais agiu inteira; essas poderiam datar do momento de sua liberdade. Antes dela, não poderiam ter existido acontecimentos verdadeiramente nacionais. O mesmo não ocorreria com as festas particulares. Uma cidade poderia celebrar o nascimento de um homem ilustre, que recebeu a vida dentro de seus muros, ou as ações generosas de seus cidadãos. Há grandes homens e belas ações sob todas as constituições (CONDORCET, 2008, p. 192).

Ao participarem de tais eventos, organizados e fiscalizados pelo Estado, os jovens e adultos aprenderiam as datas importantes da história do país, como por exemplo, a conquista da sua liberdade, os sentimentos de liberdade, independência, patriotismo capazes de formar a moral das nações e a política dos homens livres. Ao contrário do que acontecia nas solenidades públicas existentes, Condorcet (2008) propunha a substituição das apresentações de marchas, inspeções e evoluções militares pelos exercícios de ginástica "próximos de nossos costumes", considerados mais próprios do que aqueles para "evitar os efeitos dos hábitos prejudiciais que certas profissões fazem adquirir". As danças deveriam ser compostas de figuras e movimentos que lembrariam os acontecimentos que se querem celebrar. Os espetáculos seriam preparados em locais “cujas decorações e inscrições falariam a mesma linguagem, levariam às mesmas ideias, e os exercícios seriam, ao mesmo tempo, uma diversão para a juventude e a infância, um espetáculo para a idade madura e para a velhice" (CONDORCET, 2008, p. 193-194).

As celebrações públicas, de acordo com Condorcet (2008), deveriam ser ocasiões nas quais proclamar-se-iam as honras públicas concedidas à memória "dos homens de gênio, aos cidadãos virtuosos, aos benfeitores da pátria"; o relato de suas ações, a exposição de seus trabalhos seriam "um motivo poderoso de emulação e uma lição de patriotismo ou de virtude”. Aos homenageados vivos seriam distribuídos prêmios e coroas. "Os prêmios devem ser reservados para aqueles que melhor tenham feito algo útil, um livro, uma máquina, um remédio, etc" (CONDORCET, 2008, p. 195) para a sociedade.

Os jovens se preparariam para se distinguir nas festas, e não haveria necessidade de mais preparativos para introduzir na educação o uso de exercícios úteis. Julgar-se-ia com solenidade se tal homem, tal ação, tal acontecimento é digno dessa honra, e uma festa concedida a uma capital se tornaria uma recompensa para toda a província (idem, ibidem). 
Em Portugal, na transição do século XVIII para o XIX, por exemplo, a participação dos grupos de jovens nas festas públicas acontecia nos rituais definidos ao longo do ano, mas poderia dar-se a qualquer momento, de acordo com o valor concedido a um determinado acontecimento, que poderia ser merecedor de críticas ou comemorações. O alvoroço resultante dos costumes dos jovens em festejar situações consideradas benéficas e de manifestar-se contra condições indesejadas era ao mesmo tempo bem visto pela comunidade, pois, além de ser elemento fundamental da sua aprendizagem social, era também a garantia da unidade e da segurança da coletividade, que se sentia segura observando a atuação da polícia em casos de violência (CRESPO, 1990), mas também era considerada uma ameaça a ser controlada. Neste caso, o projeto de controle da população passou pelo controle do corpo dos jovens na festa (CRESPO, 1990):

Para além da violência contida nos divertimentos de touros e nos confrontos entre aldeias, diversas circunstâncias festivas constituíram objeto de prevenção das autoridades. Assim, nos arquivos da polícia, verifica-se uma atenção particular aos excessos cometidos no quadro das atividades lúdicas da juventude, em particular daquelas que eram da iniciativa dos jovens do sexo masculino (CRESPO, 1990, p.334).

No decorrer do tempo, a autonomia apresentada pelos jovens nas comemorações sociais tornou-se intolerável para as autoridades, que desejavam serem os únicos responsáveis pela vida dos jovens. A polícia reconhecia a existência e a força social destes grupos e, pouco a pouco, foi substituindo sua antiga condescendência por ações menos tolerantes e mais agressivas, impondo a ordem por uma pedagogia da repressão. As transformações na festa estiveram relacionadas à mudança de regime político: “... é que uma grande tarefa se apresentava às autoridades do Estado, tendo em vista eliminar um Antigo Regime de alegria e de jogo temperado pela violência, a favor da alternativa constituída por divertimentos considerados mais civilizados" (CRESPO, 1990, p.354). Entretanto, a supressão da festa funcionou como um artifício para suprimir as manifestações juvenis, já que as mesmas representavam os velhos costumes na vida das populações.

A partir daquele momento, as festas precisariam divulgar valores do mundo civilizado, a modernidade entendida como sinônimo de civilidade e valores morais. A polícia do Estado achava que a quantidade excessiva de festas a prejudicava, favorecendo a preguiça, a ociosidade, as despesas desnecessárias e a libertinagem. Além do Estado, os economistas e moralistas também achavam o número de comemorações 
excessivo e prejudicial à civilidade da população: o excesso de dias feriados obrigava à pausa sistemática do trabalho nos campos e nas oficinas, "circunstância inexplicável perante tanta miséria, levando à morte de muitos seres humanos por se encontrarem privados do necessário sustento" (CRESPO, 1990, p.357-358); em termos econômicos, “o povo Português perde em vinte e três dias festivos (são os que deviam ser dispensados) três milhões e quarenta e cinco mil cruzados" (idem, p.359).

Como alternativa, a Igreja Católica adaptou-se à situação com sutileza, segundo Crespo (1990), não eliminando os dias festivos, mas criando a possibilidade dos fiéis realizarem seus trabalhos cotidianos mesmo nos dias das festas religiosas, insistindo, entretanto, na obrigatoriedade de assistência à missa nesses dias, que deveria ser realizada pelo pároco "ao romper da manhã" com o objetivo de não prejudicar o dia de produção. A redução dos dias festivos determinados pela Igreja aconteceu devido a dois motivos: primeiro, pela necessidade de aumentar o tempo de trabalho: "sabia, por exemplo, que a utilidade espiritual de tão grande número de festas era cada vez mais colocada em dúvida, na medida em que também neste caso a quantidade parecia comprometer a qualidade" (CRESPO, 1990, p.364); e segundo, pela diminuição do fervor religioso, fenômeno percebido desde o século XVIII:

\begin{abstract}
A tendência que se verificava no sentido da diminuição das festas era possível numa época em que o trabalho começava a se impor como um valor fundamental na vida da sociedade, competindo assim com a religiosidade na definição do mérito dos homens. A contenção e a disciplina reveladas no trabalho não entravam, afinal, em contradição com as obrigações em relação a Deus, tratando-se de assegurar, sem má consciência, uma correta e honrada presença no mundo. Os comportamentos de autoridade estavam igualmente representados na vida religiosa e no trabalho, sendo cada vez mais o ponto de referência decisivo no esforço de aperfeiçoamento humano (CRESPO, 1990, p. 364).
\end{abstract}

Nos finais do século XVIII, a religiosidade já não conseguia mais dar forma a todas as festividades; foi assim que as autoridades logo se viram obrigadas a garantirem novos substitutos à realidade; exemplo disso foi a constituição das comemorações civis. As mudanças sugeridas marcaram a separação entre as festas religiosas e as festas civis, "remetendo o sagrado e o profano para os seus limites próprios" (idem, p.366). As festas religiosas permaneceriam aos domingos e as grandes datas da Igreja e festas civis deveriam ser destinadas à comemoração das datas históricas, das personagens históricas, dos valores e dos cultos cívicos. 
Destacou-se ainda a mudança no tipo de divertimentos oferecidos: se antes a festa era organizada pelo povo nas ruas, em um segundo momento os espetáculos deveriam ser organizados de forma mais interna e em locais específicos para isto, a fim de comemorar eventos dignos de serem lembrados. Enquanto no passado os acontecimentos memoráveis eram os ritos de passagem relativos à vida do soberano e de sua família, devido às novas condições políticas, outro gênero de festejos se perfilava em substituição daqueles, "trazendo consigo outras idéias e novas concepções de mundo, revelando-se num contexto de valores e de modelos culturais diferentes" (CRESPO, 1990, p.367). As festas, a partir deste momento, deveriam homenagear ao mesmo tempo, a Pátria e Deus (Nação e Religião). As Festas Constitucionais, representativas da Nação, por exemplo, mesmo apesar da sua não continuidade, constituíram uma ruptura com o passado representado pelos festejos interessados em celebrar a santificação de príncipes e reis.

$\mathrm{Na}$ festa da revolução estava em jogo, igualmente, um outro espaço, um outro mundo, não definido exclusivamente pela presença da Côrte e da Igreja, mas antes delineado pelas periferias onde os homens se encontravam por sua iniciativa e responsabilidade, onde podiam, eles próprios, erguer o 'mastro' à sua dimensão mais justa (CRESPO, 1990, p.375).

Depreende-se a partir dos referenciais mobilizados, que as festas mudaram no decorrer da história da humanidade de acordo com as variações sociais, econômicas, políticas e religiosas. Foram estes elementos que permitiram, por exemplo, a organização das primeiras festas civis em substituição ou complemento às festas reais e religiosas. Entretanto, apesar das mudanças de temas, existiram permanências relacionadas ao simbolismo e ao ritual, componentes que deveriam ser facilmente compreensíveis por aqueles que participavam das festas. O potencial educativo da festa estaria presente tanto na sua apresentação original, de acordo com as prescrições governamentais ou religiosas, assim como na apropriação pelos seus participantes. Neste sentido, este simbolismo e ritual que se transformam, podem ser considerados componentes do maquinário festivo: utiliza-se a mesma ocasião para atingir objetivos diferentes, tais como evangelizar, divertir, descansar, homenagear, ordenar, disciplinar, marcar o tempo e ensinar. Tais transformações indicam que os elementos que caracterizam as festas podem mudar, serem trocados ou suprimidos, desde que outros permaneçam. 
As diferentes situações festivas descritas indicam que as comemorações, assim como propôs Durkheim (1996) para o estudo das formas religiosas, poderiam ser superiores umas às outras em diferentes sentidos: no uso mais ou menos elaborado dos conceitos, das sensações, das idéias, dos sentimentos, das imagens e, por fim, de uma sistematização mais ou menos elaborada. Entretanto, como assinala esse autor, a complexidade e a idealidade maior ou menor não são suficientes para classificar as festas em gêneros separados, são justamente estas características presentes em diferentes tempos e espaços que permitem a identificação das ocasiões festivas concebidas como ritos que se destinam a suscitar, manter ou refazer alguns estados mentais e estruturas sociais e, no caso das festas escolares, suscitar determinados aprendizados.

Percebe-se que como parte da vida dos seres humanos as festas estiveram presentes em momentos remotos da existência humana antes de adentrarem os espaços escolares organizados sistemicamente no século XIX. Nos primeiros tempos, indicando a ordem da vida social e doméstica, revigorando as forças por meio da fé e dominando a natureza por meio dos rituais. Ao configurarem-se como elementos constitutivos da cultura escolar, as comemorações passam, assim como a educação escolar, por um processo de normatização e esquadrinhamento, onde tudo deveria ser pensado, planejado e organizado de acordo com os melhores resultados educativos. A festa escolar, então, perde muito das características iniciais associadas à liberdade e transgressão de uma determinada ordem, sendo que as regras que a organiza serão as mesmas que a torna ideológica (DUVIGNOUD, 1983) especialmente na configuração escolar que se organiza para as sociedades republicanas brasileira e portuguesa.

Com a sua programação, previamente definida pelas autoridades educacionais, ensaiada e apresentada pelos professores e alunos não permitia erros, nem improvisações, mas a execução mais próxima da perfeição possível, afinal, toda a vida escolar, no seu melhor funcionamento, deveria ser apresentada pelo dispositivo panóptico $^{38}$ (FOUCAULT, 2004) que representou a festa. Entretanto, seria um equívoco

\footnotetext{
${ }^{38}$ A figura arquitetural do panóptico de Bentham obedece a um princípio conhecido: "na periferia uma construção em anel; no centro, uma torre; esta é vazada de largas janelas que se abrem sobre a face interna do anel; a construção periférica é dividida em celas, cada uma atravessando toda a espessura da construção; elas tem duas janelas, uma para o interior, correspondendo às janelas da torre; outra que dá para o exterior, permite que a luz atravesse a cela lado a lado. Basta então colocar um vigia na torre central, e em cada cela trancar um louco, um doente, um condenado, um operário ou um escolar. Pelo efeito da contraluz, pode-se perceber a torre, recortando-se exatamente pela claridade, as pequenas silhuetas cativas nas celas da periferia. Tantas jaulas, tantos pequenos teatros, em que cada ator está
} 
dizer que a alegria, o divertimento e a liberdade estavam totalmente distantes das festas escolares, como toda celebração, estes sentimentos são constitutivos e definidores do evento festivo; entretanto, na escola, estes elementos deveriam ser controlados, garantidos na certa medida da identificação do conceito festa.

Concebidas como uma máquina, um artefato ou uma técnica, as festas apresentam uma série de componentes capazes de fazê-las serem compreendidas e exercerem atração em diferentes contextos sociais e históricos. Esse conjunto de elementos pode ser denominado de uma técnica da festa é composto de um ritual, de uma teatralização, que se repete em comemorações realizadas por diferentes instituições sociais (Estado, Igreja, instituições de ensino). Concebida como "situação ritual de reprodução simbólica de relações sociais" (BRANDÃO, 1978, p.10), dessa cultura da festa pode-se identificar alguns elementos que se repetem e são transformados de acordo com seu propósito da festa. Para Del Priore (2000), a compreensão total do fenômeno festa só pode ser atingida quando se considera todas as manifestações de sua chamada "prismática vivência", que comporta os gestos, os bailados, o entretenimento, a violência, as funções mágicas e políticas da festa. Desse modo, a festa pode ser concebida como expressão teatral de uma organização social nas quais os papéis sociais podem ser confirmados ou invertidos. A técnica da festa permite que ela seja ressignificada em diferentes contextos, bem como que ela seja apropriada de diferentes formas em um mesmo contexto social e político. Este é o caso, por exemplo, das festas escolares que foram objeto de discursos pedagógicos e de justificativas para os seus usos, cujas elaborações teóricas são objeto de análise do capítulo que se segue.

sozinho, perfeitamente individualizado e constantemente visível” (FoUCAULT, 2004, 28 a edição, p. 165 166). 


\title{
Capítulo 2: No palco da festa: as comemorações escolares nos discursos e nas práticas educativas renovadas
}

\begin{abstract}
A primeira vez que vi o estabelecimento, foi por uma festa de encerramento de trabalhos.

Transformara-se em anfiteatro uma das grandes salas da frente do edifício, exatamente a que servia de capela; paredes estucadas de suntuosos relevos, e o teto aprofundado em largo medalhão, de magistral pintura (...). Desarmado o oratório, construíram-se bancadas circulares, que encobriam o luxo das paredes. Os alunos ocupavam a arquibancada. Como a maior concorrência preferia sempre a exibição dos exercícios ginásticos, solenizada dias depois do encerramento das aulas, a acomodação deixada aos circunstantes era pouco espaçosa; e o público, pais e correspondentes em geral, porém mais numeroso do que se esperava, tinha que transbordar da sala da festa para a imediata. Desta ante-sala, trepado a uma cadeira, eu espiava. Meu pai ministrava-me informações. Diante da arquibancada, ostentava-se uma mesa de grosso pano verde e borlas de ouro. Lá estava o diretor, o ministro do império, a comissão dos prêmios. Eu via e ouvia. Houve uma alocução comovente de Aristarco; houve discursos de alunos e mestres; houve cantos, poesias declamadas em diversas línguas. O espetáculo comunicava-me certo prazer respeitoso (POMPÉIA, 1998, p. 16-17).
\end{abstract}

As comemorações escolares impressionaram os que dela participaram, marcaram suas memórias, constituindo-se em eventos de fascínio social, cuja potencialidade educativa deveria ser explorada pelos educadores e reformadores da instrução básica de finais do século XIX e início do século XX. Ao descrever o seu primeiro contato com a escola, o menino Sérgio, narrador e protagonista do romance $O$ Ateneu $\left(1888^{39}\right.$, 1998), nos dá indícios importantes acerca do que representaram as festas escolares para as crianças que as vivenciaram, primeiramente como espectadores e, depois, como protagonistas. Por meio delas, as crianças podiam construir uma representação inicial do que significava ser aluno de uma determinada instituição escolar em um contexto social e histórico específico, ou seja, compreender o significado dessa categoria e a composição de uma das expressões do habitus escolar. As solenidades eram ocasiões públicas nas quais os alunos poderiam se apropriar de maneiras diferentes dos espaços e dos conteúdos escolares, ou seja, atribuindo a essas ocasiões, significados diferentes dos comumente vivenciados.

\footnotetext{
${ }^{39}$ Ano de publicação da primeira edição do romance de Raul Pompéia.
} 
A escola era toda transformada para a realização das festas, seus espaços, funcionamento e decoração eram modificados por ocasião delas; além disso, eram situações nas quais os comportamentos e os saberes dos professores e alunos ganhavam uma dimensão pública mais significativa, uma visibilidade não experienciada cotidianamente. Enfim, o dispositivo ${ }^{40}$ festivo pressupunha a operacionalização de técnicas, saberes e fazeres dos diferentes profissionais e alunos, traduzidos do cotidiano escolar. Nesta direção, caberiam alguns questionamentos: como se organizaram as argumentações, nas fontes selecionadas, acerca dos aprendizados possíveis aos alunos por meio das festas? O que diziam as fontes sobre os saberes prévios dos alunos requisitados no planejamento e na execução das festas? Quais conteúdos curriculares contribuíram para a realização das comemorações escolares? Quais valores e comportamentos estiveram associados à categoria aluno nessas situações? Qual habitus escolar os alunos deveriam apresentar? Enfim, quais aprendizados as festas favoreceram?

Neste capítulo, pretende-se discutir como foram construídas as argumentações que contribuíram para a criação da concepção de festa pedagógica em finais do século XIX e início do século XX, especialmente investigadas a partir dos pedagogos representantes do modelo escolar renovado, assim como os principais saberes associados às festas que deveriam ser indicados aos alunos para a sua realização, além de quais aprendizagens escolares elas possibilitaram. Sabe-se que para se compreender o discurso pedagógico faz-se necessária a apreensão de uma trama tecida de discursos provenientes de diferentes campos e agentes. A escolha dos autores teve como critério a seleção de nomes que foram e são referências em trabalhos pedagógicos de divulgação mundial, e em especial, para os países investigados, Brasil e Portugal. Cabe destacar que a discussão sobre a renovação das metodologias de ensino inseriu-se em um projeto mais amplo que pretendeu a instituição da modernidade pedagógica em escolas do mundo todo, prevendo, para todas elas, um mesmo modelo de ensino fundamentado em discursos científicos de áreas distintas como a medicina, a psicologia e a própria pedagogia, que então se constituía enquanto ciência (SCHRIEWER; NóvOA, 2000).

Mesmo não tratando especificamente das festas escolares, alguns autores apenas mencionam a importância de iniciativas desse tipo no âmbito escolar (DEWEY, 1936; ClaparÈDE, 1933; LIMA, 1914). É possível perceber nos discursos destes

\footnotetext{
${ }^{40}$ De acordo com conceitualização elaborada por Michel Foucault (2004), o dispositivo traduz estratégias de forças sustentadas por saberes distintos e sendo sustentado por eles.
} 
educadores justificativas que fundamentaram a proposta e realização das comemorações escolares, bastante noticiadas, além dos textos teóricos, em artigos das revistas de ensino, nos manuais pedagógicos e na legislação do período, analisados nesta tese. Desse modo, o objetivo deste capítulo é examinar de que forma tais educadores pensaram as atividades festivas e quais foram os argumentos teóricos e metodológicos que permitiram a disseminação dessa prática nas escolas públicas portuguesas e paulistas. Para isso, fez-se necessário compreender como as várias premissas enunciadas por educadores como Dewey, Claparède, Ferrière, Lourenço Filho, Adolfo Lima, Álvaro Lemos, Émile Planchard e Faria de Vasconcelos, representantes selecionados do movimento da Escola Nova nos países em questão, puderam ser realizadas por meio das comemorações escolares, compreendendo como esses estudiosos conceberam as festas escolares, as funções atribuídas às mesmas no contexto escolar e/ou de ensino e aprendizagem, bem como a realização dos princípios da escola nova promovidos por meio das festas.

\section{1- A experiência da festa no ideário renovado: a centralidade da criança}

A constituição da pedagogia moderna no século XIX teve como expressão maior o movimento de renovação educacional intitulado Escola Nova ${ }^{41}$. Essa proposta educacional também foi conhecida mundialmente de forma relacional a expressões tais como: 'métodos ativos', 'educação centrada na criança', 'autonomia da criança' e 'pedagogias não-diretivas'. Foi uma maneira diversa de conceber a educação e o educando, baseando seus métodos pedagógicos em estudos científicos acerca do desenvolvimento dos aspectos afetivo, social e intelectual da criança rompendo, desse modo, com o modelo estritamente intelectualista que no contexto histórico se convencionou chamar Educação Tradicional, modelo escolar característico e conhecido na fase de extensão e massificação de uma escola básica, controlada pelos estados industrializados (CANDEIAS; NóvOA, 1995).

\footnotetext{
${ }^{41}$ No Brasil, as reformas empreendidas em vários estados nos anos de 20 e 30 do século XX são comumente apresentadas como o movimento fundador da modernidade pedagógica no país; o que precisa ser relativizado ao se levar em consideração, por exemplo, os antecedentes da coroa portuguesa no país ao construir um programa de reforma cultural e educacional presentes na política pombalina; os efeitos de penetração do protestantismo sobre o monopólio educativo católico; bem como as críticas e movimentos reivindicatórios dos professores primários públicos da corte em luta contra a elite imperial (NUNES, 2003).
} 
Ao mesmo tempo em que se percebeu um forte sentimento de descrença frente às propostas educativas tradicionais, que não cumpriram as suas finalidades, segundo os pedagogos escolanovistas, foi divulgada a possibilidade de renovação e transformação da sociedade por meio de um outro paradigma escolar. Existiu, assim, um sentimento ambíguo, de desconfiança e de descrença na instituição escolar. Desconfiança com relação à escola dita tradicional e ao seu modo de educar e, ao mesmo tempo, a forte crença transformadora das instituições escolares renovadas. Faz-se relevante notar que é a primeira vez na história da pedagogia que uma corrente de pensamento baseou suas propostas de ação numa crítica de fundo ao modelo escolar então vigente.

A Educação Nova é o princípio do fim de um 'discurso escolarizante' sobre a educação das crianças. Mas é também o exarcebar da crença nas potencialidades da escola (de uma outra escola, claro) (...) Nunca ninguém desconfiou tanto da escola e nunca ninguém acreditou tanto na escola como os grupos que dêem corpo e voz à Educação Nova (NóvoA, 1995, p. 31).

Em linhas gerais, o programa divulgado pelos escolanovistas, foi tido mais como um conjunto de ideais desconectas do que um efetivo conjunto de princípios de ação (NóVOA, 1995), contemplando 30 características que podem ser agrupadas em torno de cinco idéias centrais: 1) a escola nova é um laboratório de pedagogia prática, devendo funcionar, preferencialmente, em regime de internato e situar-se numa zona rural, já que ela procura criar uma ambiência saudável e de proximidade com a natureza (excursões, acampamentos, criação de animais, trabalhos agrícolas, ginástica natural, celebração da natureza, etc); 2) a proposta renovada pressupõe o sistema de coeducação dos sexos; 3) destaca-se, também, uma particular atenção aos trabalhos manuais; todo o ensino deve organizar-se a partir de métodos ativos, que estimulem o gosto pelo trabalho e a criatividade; 4) o desenvolvimento do espírito crítico deve acontecer por meio da aplicação do método científico; 5) o cotidiano da escola nova alicerça-se no princípio da autonomia dos educandos, que devem ser corresponsáveis no processo de ensino. O impacto das teses e das práticas da Educação Nova sobre as realidades escolares foi relativamente limitado e seguiu os contornos impostos pelas condições concretas de aplicabilidade em cada país, que, de certa forma, explicou o desalento dos educadores nos anos de 1930, caracterizado pela perda do entusiasmo inicial e da capacidade de produzir as modificações condizentes ${ }^{42}$. Entretanto, a contribuição desse

\footnotetext{
${ }^{42}$ Jorge Nagle (1978) indicou de forma marcada dois momentos desse processo de penetração das ideias renovadas de ensino no Brasil, especialmente no Estado de São Paulo: o primeiro, intitulado entusiasmo
} 
movimento para o desenvolvimento de uma visão diferente de criança e do ato educativo é significativa no âmbito dos acontecimentos histórico-educacionais, cujas heranças podem ser percebidas até os dias de hoje em algumas práticas escolares.

Alicerçada em justificativas das áreas da psicologia, num primeiro momento, e da sociologia posteriormente, a proposta renovada concebeu o ensino baseado nas atividades e nas necessidades da criança, condição pioneira na organização das atividades escolares. Nas palavras de Adolpho Ferrière (1934), a escola ativa deveria ser, antes de tudo e de uma forma geral, a aplicação das leis da psicologia à educação das crianças: "dum lado, a sociologia, e doutro lado, a psicologia genética estudando o desenvolvimento dos seres, eis as ciências-mães desta ciência aplicada ou desta arte que é a educação" (FERRIÈRE, 1934, p. V). O aprendizado real e efetivo só seria possível com a participação e envolvimento da criança em todo o processo educativo - "o verdadeiro meio de direção, ou controle social das atividades dos educandos, é a sua participação com outras pessoas em atividades comuns, cujo sentido e finalidade eles adotem plenamente" (DEWEY, 1936, p. 24). Ao educando não era mais requerida a passividade anterior, mas sim, uma participação mais ativa em todas as realizações escolares que possibilitassem o pleno desenvolvimento de suas capacidades cognitivas, psicológicas e sociais.

A aprendizagem no ensino ativo consistiu na aquisição gradual e individual de habilidades por cada criança, que deveria ser levada a aprender, pelo seu educador "vigilante" e perspicaz, capaz de garantir o meio e mobilizar os interesses dos seus educandos. Cada educando deveria assegurar recursos para aprender por meio da observação, da pesquisa, do trabalho, da construção, do pensamento e da resolução de situações problemáticas relacionadas à sua própria vida. Fazia-se necessário, desse modo, oferecer, no ambiente educacional, oportunidades para que os alunos sentissem a necessidade e o interesse em resolver situações difíceis; que aprendessem com essas situações e que, por fim, conseguissem resolvê-las em razão do seu próprio esforço (LOURENÇO FILHO, 1963, 8 a edição). Para Claparède (1933), a escola ativa, ao contrário da proposta de ensino anterior, está baseada no princípio da necessidade; "para fazer com que o vosso discípulo aja, colocai-o em circunstâncias tais que experimente a necessidade de executar a ação que dele esperais" (p.189). O envolvimento total da criança na atividade educativa deveria ser capaz de desenvolvê-la integralmente,

pela educação, e o segundo, otimismo pedagógico, o que ainda hoje é tema de debates entre os historiadores. 
garantindo, não somente o aprendizado dos conteúdos das diferentes disciplinas, mas também de atitudes e de valores cujo interesse nas atividades escolares seria mantido pela problematização de situações da própria vida da criança, tanto intelectual quanto socialmente.

A noção de atividade, considerada como o eixo articulador entre o ensino e aprendizagem na nova proposta de ensino, esteve presente em quase todos os estudos dos distintos pedagogos escolanovistas, que atribuem a este conceito, um significado diferente do utilizado nos moldes tradicionais. Segundo esses teóricos, o conceito de atividade precisaria ser bem conhecido na sua ambiguidade pelos educadores que se desejassem disseminadores das novas propostas.

De acordo com Claparède (1933): o primeiro sentido do conceito estaria relacionado ao seu caráter funcional: é uma ação ou reação que corresponde a uma necessidade, despertada por um desejo e tendo como ponto de partida o indivíduo que age, relacionando-se às ideias de necessidade, interesse, desejo, disciplina interior, móveis interiores, consentimento do indivíduo, espontaneidade, liberdade e atenção espontânea. Já a segunda acepção, estaria relacionada à ideia de efetivação, expressão, produção, processo centrífugo, mobilização de energia, trabalho, expressão, produção (ou reprodução), exteriorização, reação, processo centrífugo, invenção, movimento, trabalho (escola-oficina). Aqui, atividade se opõe a "recepção, ideação, sensação, impressão e imobilidade" (CLAPARÈDE, 1933, p.196). As atividades festivas, compreendidas de forma abrangente, apresentariam como ponto de partida a ação dos diferentes indivíduos (professores e alunos); instigada por interesses e necessidades contribuiriam, a partir dos seus processos de elaboração e concretização, para o aprendizado ativo do educando. As duas acepções se complementariam, mas a segunda definição sem a primeira não foi característica da escola ativa. Sendo assim, não foram todas as atividades escolares que se transformaram em aprendizado eficaz para os educandos.

A atividade dos alunos não basta para tornar uma escola 'ativa', enquanto não se tiver dado à palavra 'atividade' o seu sentido completo. A palavra 'ativo' é uma palavra vaga. Para muitos 'ativo' quer dizer que se move, se agita, que executa um trabalho, que escreve, que desenha, que faz alguma coisa em lugar de se limitar a escutar. (...) Pergunto-me, porém, (peço perdão ao meu amigo Bovet que o formulou por primeiro) se o termo 'escola ativa' não é também ambíguo. Figura-se que ativo significa 'que age exteriormente'; que a atividade desenvolvida é proporcional ao número de atos visíveis executados. Ora, digo que um indivíduo que pensa, sem se mexer no 
fundo de sua cadeira, pode ser muito mais ativo do que um aluno que faz uma tradução de latim (CLAPARÈDE, 1933, p.186).

Para se transformar em aprendizagem, a atividade deveria ser planejada e controlada, no sentido de garantir a melhor reflexão da experiência vivida para o educando. Aqui se apresenta uma problemática instigante: como garantir o interesse da criança em uma atividade controlada? Neste caso, o meio direto de controlar ou de governar a educação seria "o de preparar o ambiente que a criança age, pensa e sente" (DEWEY, 1978, p.19). Em um ambiente previamente organizado, a criança tem a oportunidade de realizar todas as suas experiências e retirar delas o maior proveito possível. A experiência educativa consiste numa experiência inteligente, na qual participa o pensamento, e na qual existe a possibilidade de percepção das relações e continuidades não percebidas: "todas as vezes que a experiência for assim reflexiva, isto é, que atentarmos no antes e no depois do seu processo, a aquisição de novos conhecimentos, ou conhecimentos mais extensos do que antes, será um dos seus resultados naturais" (DEWEY, 1978, p. 07). Em outras palavras, a realização de atividades previamente organizadas acarretaria "naturalmente", o aprendizado pleno de todos os escolares.

De acordo com Dewey (1978), a educação deveria ser o processo de reconstrução e de reorganização da experiência. A instrução e educação "não são resultados externos da experiência, mas a própria experiência reconstruída e reorganizada mentalmente no curso de sua elaboração" (DEWEY, 1978, p. 09). O conceito de experiência, segundo Dewey (1978), poderia ser compreendido como a ação de um corpo qualquer do universo sobre o outro e a reação sofrida por este; sendo assim, o conceito de experiência não se limita às experiências humanas, mas se relaciona a atividade permanente de todos os corpos do universo, uns sobre os outros. A "experiência é uma fase da natureza, é uma forma de intenção pela qual os dois elementos que nela entram - situação e agente - são modificados" (DEWEY, 1978, p.02). Este autor, desse modo, concilia o dualismo existente na perspectiva do racionalismo e do intelectualismo, da natureza e da experiência, na qual a experiência tornava-se apenas um elemento de análise daquela. A experiência é uma relação que se processa entre dois elementos do cosmos, alterando-lhes a realidade. No âmbito escolar, o ato de conhecer algo, leva a uma alteração simultânea "no agente do conhecimento e na coisa conhecida" (idem, p. 03). Nem todas as atividades realizadas na escola seriam em si 
mesmas cognitivas, mas elas poderiam ganhar esse atributo a partir da elaboração reflexiva das mesmas.

As festas escolares, como experiências educativas, prolongaram seus ensinamentos para antes e depois da sua realização, garantindo por meio da participação e atividade do aluno novas possibilidades de aprendizado tanto dos conteúdos escolares, quanto das normas e dos valores implícitos nos temas de cada festa. Neste sentido, a festa alargava-se para antes e depois do próprio ato, de dois modos diferentes e complementares: num momento anterior, representado pelo conhecimento que a festa exigia acerca dos modos próprios de organizá-la (previsto nos regulamentos, circulares, experiências anteriores), no estudo dos temas das festas e suas relações com os outros saberes curriculares, bem como o seu significado para a vida escolar e social; após o evento, seu efeito poderia ser percebido na disseminação das notícias nos jornais e periódicos que buscaram traduzir em palavras o ato festivo, e nas lembranças daqueles que dela participaram. A própria festa enquanto experiência pode ser considerada por si só educativa: "o fim (resultado) da educação se identifica com seus meios (o processo), do mesmo modo, aliás, que os fins da vida se identificam com o processo de viver" (DEWEY, 1978, p. 08). Como evento social, as comemorações sempre fizeram parte da vida do ser humano, e na escola não deveria ser o contrário.

No âmbito da Escola Nova, a criança foi considerada na sua integralidade e a atividade escolar deveria desenvolver, no máximo possível, todas as capacidades do educando. Era necessário, ainda, conservar as energias úteis e construtivas do aluno para fazer dele uma personalidade autônoma e responsável (FERRIÈRE, 1934, p. V). Acreditou-se que tudo que se ensinava de fora ou se impunha ao educando, sem contato com as energias interiores, tenderia a desequilibrá-lo e a prejudicá-lo; por esse motivo, a escola ativa procurou fazer predominar o espírito, isto é, a intuição, o coração, a razão e a vontade na sua essência qualitativa no processo educativo.

As festas escolares parecem-nos, assim uma das atividades educativas exemplares da concretização das premissas renovadas que colocam o educando no lugar central no processo de ensino e aprendizagem, capaz de, ao mesmo tempo, desenvolvêlo cognitiva e emocionalmente. Ela deveria ser a ocasião privilegiada para o educando ser visto e se fazer ver, de incitar o interesse da criança pelo evento que estava sendo comemorado, despertar seu intelecto, seus sentimentos e suas emoções. Além disso, ainda foi possível perceber a consideração do desenvolvimento infantil como um todo. Em grande parte dos programas festivos, existiram horários específicos para a 
demonstração do desenvolvimento intelectual: nos exames, nas recitações de poesias e de exibições físicas nas apresentações de ginástica, além de todo o controle emocional que a autodisciplina nestes eventos demandou. Valorizava-se a autonomia das crianças, que eram ensaiadas durante longos períodos; em alguns casos, durante todo o ano escolar, e tomavam para si a responsabilidade pelo desenvolvimento e bom andamento da festa. Além disso, a realização de uma festa dependia sempre do interesse e da atividade do aluno, principal protagonista do evento, dependendo dele o seu sucesso. A experiência festiva reconstruída e reorganizada transformar-se-ia na atividade capaz de garantir o interesse e a funcionalidade da educação, reunindo, em um só evento, conceitos caros ao movimento renovador.

As comemorações escolares, assim como a educação, deveriam ter um valor funcional (CLAPARÈDE, 1933), ou seja, ser capazes de desenvolver os processos mentais considerando-os, não somente em si mesmos, mas também quanto a sua significação biológica, à sua utilidade para a ação presente ou futura, ou seja, para a vida. A "educação funcional é a que toma a necessidade da criança, o seu interesse em atingir um fim, como alavanca da atividade que se lhe deseja despertar!" (CLAPARÈDE, 1933, p. 02). A sua funcionalidade não poderia ser resumida somente na sua atratividade, já que nem tudo que se faz atraente possui um valor educativo, mas também naquilo que ela apresentou como utilidade.

Infere-se, a partir das considerações deste autor, que as festas escolares, ao mesmo tempo em que deveriam ser atrativas e garantir o envolvimento e participação de todos os atores escolares, deveriam ser permeados pelo seu caráter educativo. Dessa forma, as festas eram compreendidas como momentos nos quais a criança poderia expressar toda a sua alegria e espontaneidade, sendo que para isto ela deveria viver a festa, fruí-la e aproveitá-la no que ela teria de mais prazeroso. As festas assumiriam a função de autonomizar a criança, quando ela deixava de ser o mero espectador e tornava-se a protagonista do seu aprendizado e responsável pelo sucesso do "teatro da festa". A centralidade da criança nas festas foi reconhecida em solenidades dedicadas exclusivamente a elas, como aconteceram nas denominadas "festas das crianças", levadas a efeito nas décadas de 1920 e 1930, período que poderíamos considerar de maciça divulgação dos ideais renovados.

No Brasil, as notícias e comentários específicos sobre a Festa da Criança concentraram-se nas páginas da Revista Escolar, que circulou no contexto educacional paulista entre os anos de 1925 e 1927 e esteve associada à divulgação dos princípios da 
escola nova nesse contexto. Ao todo, foram registrados cinco textos do mesmo periódico, do qual se destacaram alguns: o primeiro tratou da comemoração do dia 12 de outubro, já instituído "Dia da Criança", no Teatro Municipal de São Paulo, para um público composto de três mil crianças das escolas paulistas, onde "o palco será adaptado de modo a bem acomodar tão numeroso corpo de cantores, talvez o maior que se tenha organizado até aqui. (...) O programa, otimamente organizado, é todo composto de músicas de reputados autores brasileiros, adaptadas às vozes infantis" (Revista Escolar, setembro de 1926, p. 86) e segundo o autor da notícia, seria "de prever o brilhantismo da festa, dada a competência do seu organizador, o maestro João Gomes Junior, inspetor especial de música nas escolas públicas do Estado", que não havia poupado "esforços no sentido de conseguir os mais surpreendentes efeitos corais e a maior disciplina musical do conjunto" (Revista Escolar, setembro de 1926, p. 86).

A associação feita entre o sucesso do evento e os esforços do professor para a organização e ensaio do coral de crianças indica a contradição assinalada alhures sobre a questão do interesse da criança e a realização das atividades escolares. Apesar de caracterizar-se como uma festa para criança, a sua participação foi restrita a execução de cantos previamente escolhidos e, ainda quem sabe, sofridamente ensaiados pelos alunos com o mestre. Às crianças, muitas vezes, caberia uma participação passiva, restrita ao programa e com poucas oportunidades de livre expressão, como reivindica o artigo intitulado "Conceito Infantil" elaborado por Ephigenia C. Teixeira (1927) que assinalou a contradição da atividade inicialmente livre da festa:

Isto é que me dá raiva! Esta coisa é que me dana! Já viram que espalhafato numa festa tão brilhante?!

E dizem:- Festas das Crianças! ...Eu sou criança. Sou pequeno. Na minha cachola pequenina, só tenho gravado: - papai, mamãe; dê-me um tostão, papai; dê-me um doce, mamãe. E, mesmo assim, venho para a minha festa sem caber na pele, de alegria. Mas, chego aqui, dou com meus coleguinhas a recitar versos e poesias de Coelho Netto, Olavo Bilac ... Não sei de quem mais. Por isso ouvi D. Francisca perguntar ao Dr. Francisco se ele entendeu o que disse o Chico ... Versos!... Não entendo patavina! Nem a prosa entendo!... Poetas!... São uns aborrecidos. Não os entendo. Não gosto deles! ... Não gosto, mesmo. Também não gosto do Lulú, quando me ganha as bolinhas. Poetas!... Se eles falassem a minha língua! ... Fizessem versinhos alegres, e eu gostaria deles. Gostaria deles, tanto como da minha professora, porque fala a minha língua para que eu possa entendê-la... Ora também eu não hei de ser sempre pequeno! E quando eu for gente, entrarei para a academia dos poetas. Serei poeta para vingar-me dos poetas. Farei versos que eles não entendam (Revista Escolar, fevereiro de 1927, p.62-63). 
O pensamento infantil registrado nas linhas acima sugeriu a pouca compreensão que as crianças tinham de alguns momentos da festa. Para a aluna mencionada acima não faria sentido, em uma festa para crianças, recitar versos e poemas de autores, algumas vezes, desconhecidos e que não eram produzidos de forma específica para elas. Apesar da importância do conteúdo escolar, a situação da festa, segundo Ephigenia C. Teixeira (1927), não seria própria para isso. A transcrição desse comentário nas páginas da Revista Escolar de São Paulo indicou a percepção de que deveria existir uma preocupação maior com a compreensão infantil na realização das atividades festivas. Uma festa para as crianças deveria contar com atividades organizadas e levadas a efeito de acordo com a capacidade de compreensão que as mesmas teriam sobre a comemoração.

Considerando a questão da centralidade das crianças em eventos a ela destinados, a Associação de Professores de Portugal, agremiação profissional constituída por membros das diversas espécies de ensino realizou, em 1925, a considerada "primeira experiência para a realização anual de uma Semana da Criança, na primavera, com o objetivo de dar ao mundo infantil de Portugal, um clarão de alegria, chamando a atenção da consciência pública para o magno problema da infância" (Revista Escolar - Portugal, março de 1925, p. 119 - 121). Segundo os idealizadores do evento, a ideia da Semana pretendia ser, acima de tudo, "uma amorosa demonstração prática do sentimento de responsabilidade dos adultos pelos sagrados direitos da infância, - procurando que ela viva plenamente, durante alguns dias, a vida própria e feliz da sua idade" (idem). A Semana da Criança almejou envolver todas as crianças, desde a primeira infância até a adolescência, as que freqüentavam a escola e as que não tinham “essa felicidade” (Revista Escolar - Portugal, março de 1925, p. 119 121).

O projeto do programa da Semana da Criança foi feito tendo em vista as possibilidades materiais e de pessoas dos grandes centros como Lisboa, Porto, Coimbra, Évora, Braga entre outras. As localidades de médios e mínimos recursos realizariam o programa fundamental, podendo fundir-se com facilidade o $1^{\circ}$ número com o $2^{\circ}$, o $4^{\circ}$ com o $5^{\circ}$, o $3^{\circ}$ com a alínea a, do $6^{\circ}$ e, ainda, suprimir-se, no todo ou em partes, os números $4^{\circ}$ e $5^{\circ}$. Além disso, 'Semana da Criança' não deveria ser confundida com "semana inteira de festas em cada localidade, mas sim que cada localidade dê o seu concurso à obra educativa dentro daquela semana", a manifestação da "Semana" poderia ainda ser reduzida a uma hora em um só dia. "E, por mais modestos que sejam 
os recursos da localidade, é sempre possível fazer qualquer coisa" (idem, abril de 1926,

p. 173). O programa ideal proposto para o evento foi organizado da seguinte forma:

$1^{\circ}$ Dia da Festa Escolar - a) Festa na escola, por crianças para crianças com a assistência das famílias, quanto possível modelar, entre cujos números figure, embora modestamente, a exposição dos trabalhos escolares (com a única preocupação de patentear e estimular o esforço relativo e sempre precioso de toda a criança), exaltando-se em toda a festa o nobre desejo individual do progresso e o alto significado, da escola e do trabalho, da cooperação do amor etc. b) Conferências populares à noite sobre os direitos das crianças e os deveres dos pais e da sociedade para com ela.

$2^{\circ}$ Dia da solidariedade infantil - a) As crianças reúnem na escola para fundar ou aperfeiçoar, quando existir, a sua associação escolar e para prestar solidariedade aos seus companheiros de dentro e fora da escola, por exemplo, fornecer-lhes o necessário para que possam tomar parte nas festas da semana, levar brinquedos às crianças hospitalizadas, etc. b) Á noite reunião de pais, professores e amigos da infância para fundação de núcleos de defesa da criança.

$3^{\circ}$ Dia da festa ao ar livre - a) Festa nos jardins ou campos apropriados, constando de jogos educativos, cantos, bailes de roda, etc. b) Á noite, precedidos de conferências adequadas, récitas nos teatros em festa de confraternização dos amigos da infância e em beneficio dos fundos da semana.

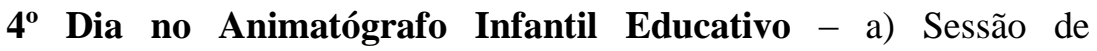
animatógrafo (ou teatro infantil educativo, onde aquele não seja possível) para todas as crianças, promovendo a assistência das desprotegidas. Em torno deste objetivo procurar-se há realizar um concurso de filmes educativos para criação e apuramento dos melhores e mais recomendáveis animatógrafos infantis educativos.

$5^{\circ}$ Dia dos Pequeninos e dos Brinquedos - a) Festas nos jardins para as crianças dos 3 aos 6 anos, constando de jogos, cantos e distribuição de bolos e brinquedos. b) Concurso e exposições de brinquedos educativos com conferências dedicadas aos pais e educadores sobre $o$ mundo infantil e o brinquedo. c) Conferências populares à noite sobre a proteção da criança na gestação e primeira infância sobre a imperiosa necessidade dos jardins da infância.

$6^{\circ}$ Dia da Confraternização Infantil - a) Concentração de crianças, desde os 7 anos, em locais próprios e por grupos de escolas tão numerosos quanto possível para uma festa em comum, tendo como base: divertimentos livres, canto coral, merenda, distribuição de dádivas próprias, como brinquedos e livros e troca de pequenas recordações entre as crianças. b) Á noite reunião magna dos delegados dos amigos da infância, em Lisboa, para fundação da União dos Defensores da Criança - que terá como um dos seus fins continuar a experiência da Semana da Criança (Revista Escolar - Portugal, março de 1925, p. 120-121).

A Semana da Criança teve uma divulgação bastante significativa, comprovada na publicação de vários artigos em números posteriores da Revista Escolar tratando de detalhes e repercussões desse acontecimento. Além disso, o governo português, considerando a Semana "uma experiência pedagógica e social com uma nobre 
preocupação do bem coletivo e um alto objetivo de progresso" (Revista Escolar Portugal, março de 1925, p. 120-121) e cabendo ao Estado auxiliar as boas iniciativas, "contribuindo com todos os meios de que disponha para facilitar a sua efetivação" (idem), mandou o "Governo da República Portuguesa, pelo Ministro da Instrução Pública, que todas as repartições públicas e entidades oficiais facilitassem, auxiliassem e colaborassem nos trabalhos conducentes à realização da Semana da Criança" (Diário do Governo, no. 64, 2a série, de 18-3-925 apud Revista Escolar - Portugal, abril de 1926, p. 175). No ano seguinte, o mesmo programa foi proposto para a festa, com algumas sugestões mais detalhadas para as escolas cujos recursos não eram tão abundantes:

Uma exposição dos trabalhos escolares; um passeio ou um lanche ou pic-nic na várzea próxima; duas ou três histórias contadas aos pequeninos; uma leitura amena ou uma preleção na escola, e, nas localidades de mais recursos, mas onde não seja possível promover a récita infantil ou produzir a sessão cinematográfica, uma velada literária, poderão constituir adequadas manifestações do interesse pela criança e pela sua melhor educação (Revista Escolar - Portugal, abril de 1926, p. 173).

A manifestação da Semana da Criança deveria ser de alegria e de prazer para elas, cumprindo evitar, por isso, a "obrigá-las a assistir a estirados discursos, ou mantêlas imóveis sob qualquer pretexto, ou fatigá-las com longas marchas" (Revista Escolar Portugal, abril de 1926, p. 172). Nos programas ao ar livre, tais como cortejos, paradas e concentrações deve "ter-se sempre presente que as crianças não entram nelas como flores ornamentais, como seres passivos que vão ali para provocar a admiração e o prazer dos adultos" (idem). Desse modo, as marchas deveriam ser curtas, evitando "formaturas rígidas, paradas angustiosas, calores torturantes, etc, etc". "Liberdade, muita liberdade, alegria, muita alegria!”. E que “os locais de concentração sejam de fácil acesso, arborizados, e com água pura e em abundância que elas possam beber" (ibidem). Até nos grandes centros não deveriam as escolas forçar-se a realizar todas as manifestações marcadas no programa, mas se restringir àquilo que puderem "fazer bem e sem cansaços, contrariedades ou divergências. Pretende-se uma manifestação de bom humor e de concórdia, e não uma origem de aborrecimentos" (Revista Escolar Portugal, abril de 1926, p. 173).

Alguns anos mais tarde, nas páginas de outro periódico português, registraramse alguns abusos praticados em festas destinadas às crianças, cuja crítica fundamental dizia respeito à má compreensão que se teve do evento, que acabou por transformar-se 
"numa semana de regabofe para a petizada" (A Escola Primária, julho de 1929, p. 348), e os abusos relacionados à criação de outras semanas, não tão relevantes, que foram instituídas a partir daquela.

Continuam fazendo as nossas delícias as variadas semanas de que entre nós se tem usado e abusado para celebrar pequenos e grandes acontecimentos. Depois da semana da criança, que chegou por má compreensão talvez, a ser transformada numa semana de regabofe para a petizada, vimos surgir semanas várias a propósito e despropósito disto ou daquilo e, nos últimos dias, mais três semanas, pelo menos, viram a luz: a semana dos combatentes, a semana dos hospitais - que, aliás, mereceram o nosso maior respeito - e até agora apareceu anunciada nos jornais uma exótica semana, a semana do chapéu de palha! (A Escola Primária, julho de 1929, p. 348).

Considerando as fontes e a potencialidade das festas para a concretização dos princípios educativos da Escola Nova, é preciso relativizar a centralidade dos alunos nos eventos comemorativos. A participação das crianças constituiu-se condição imprescindível para a organização e realização de qualquer festa que se desejava escolar; entretanto, essa participação poderia ser categorizada de duas formas: uma participação de características predominantemente passivas, quando elas atuariam como coadjuvantes do evento, assistindo tudo que era realizado como espectadores e sem possibilidades de intervenções; ou enquanto ativas, como protagonistas da festa, com a liberdade de criação garantida para composição de canções, textos, realização de homenagens, apresentações físicas e teatrais e demonstração dos seus saberes; neste caso, o interesse previsto para a atividade festiva seria mais próximo do real. Seja por meio de uma participação ora mais ativa, ora mais passiva, ou as duas em um mesmo evento, almejava-se que, assim como as outras atividades escolares, as festas garantissem o aprendizado dos educandos. 


\section{2 - As lições da festa - a garantia do interesse e o sucesso do aprendizado}

A concretização do aprendizado na proposta renovada aconteceria, num primeiro momento, mediante a garantia do interesse do educando pela atividade educativa a ser realizada. As festas foram evocadas em diferentes momentos por diferentes educadores para a garantia deste interesse, seja o interesse pela própria atividade festiva, seja pelo aprendizado de determinado conteúdo de ensino relacionado a essa ocasião, ou ainda, do interesse da sociedade pela escola. O interesse do educando, suas atividades espontâneas, manuais e construtivas, suas afeições e gostos dominantes, deveria constituir-se o ponto de partida da educação (FERRIÈRE, 1934); nenhuma atividade educativa deveria ser desenvolvida sem considerar-se, no âmbito psicológico, tal interesse (DEWEY, 1978). Na sua raiz profunda, esse termo relaciona-se a empenho, fascinação, estar absorvido em alguma tarefa ou pensamento. A própria etimologia do termo interesse, 'estar entre', não diz outra coisa: “interesse marca a completa supressão de distância entre a pessoa e a matéria e resultados de sua ação: é a união orgânica da pessoa e do objeto" (DEWEY, 1978, p. 97).

$\mathrm{O}$ "interesse verdadeiro tornava-se, desse modo, o resultado que acompanhava a identificação do 'eu' com um objeto ou uma ideia, indispensável à completa expressão de uma atividade que o próprio 'eu' iniciou” (DEwEy, 1978, p. 94). Por esse motivo, o interesse deveria surgir da própria vida do aluno, das experiências vividas rotineiramente; tudo que estaria intrinsecamente ligado à vida consciente e aos conteúdos e sentimentos da vida cotidiana poderiam ser do interesse do educando. Quando existe interesse, empenhamo-nos ativamente em alguma atividade ou pensamento. Ele pode ser concebido como algo dinâmico e pessoal, que deve nos ligar diretamente a uma coisa que tem importância para nós: "por isso, além dos seus aspectos de atividade e de objetividade, possui um aspecto emocional e pessoal" (DEWEY, 1978, p. 96).

Se a matéria das lições tiver um lugar apropriado na expansão natural da consciência da criança; se ela nascer naturalmente das atividades, dos pensamentos e dos próprios sofrimentos da criança, para servir a novas atividades e novos pensamentos, então não haverá necessidade de truques e artifícios de método para tornar o assunto 'interessante' (DEWEY, 1978, p. 76).

Não existiriam estratégias possíveis ao educador para garantir o interesse do aluno; somente a consideração das suas necessidades variáveis e de suas características individuais poderia garantir o êxito do aprendizado. No âmbito escolar, se o educador 
conseguisse o interesse do educando, sua atenção para uma série de fatos ou idéias, poderíamos estar certos de que o aluno empregaria todas as suas energias em compreendê-los e assimilá-los: "se provocarmos esse interesse para certa tendência moral ou determinada linha de conduta, estaremos igualmente certos de que nessa orientação é que se encaminharão as atividades infantis (...)” (DEWEY, 1978, p. 83).

Os interesses poderiam mudar no decorrer da vida escolar do educando conforme o seu amadurecimento, ou ainda com relação aos seus dotes individuais natos, bem como nas relações com o seu contexto histórico e social. Ao educador renovado sugeria-se a não proposição de atividades preconcebidas, mas a possibilidade de que os alunos, "livremente" escolhessem suas atividades, pois somente assim se formaria o sentimento da disciplina, ou "o hábito de lidar com coisas sérias, tão necessário à vida futura da criança" (DEWEY, 1978, p. 87) ${ }^{43}$. Por este motivo, a modulação do interesse deveria ser medida pelos educandos e não pelos professores. $\mathrm{O}$ aluno, interessado em algum tema, aprenderia por meio do seu esforço pessoal e absorvente, empreendendo todas as suas capacidades e forças em uma atividade capaz de contribuir para o seu bem-estar físico e seu desenvolvimento intelectual.

Se em alguns autores, percebia-se a indicação vaga das atividades a serem desenvolvidas pelos alunos de acordo com os seus interesses, ou seja, as atividades mudariam de escola para escola e de educando para educando, em outros, as sugestões já seriam mais explícitas. Este seria o caso das produções do pedagogo Adolpho Ferrière (1934), que concebeu o interesse como a força propulsora da atividade educativa que, organizada de forma atraente e diversificada pelo educador, poderia impedir a fadiga escolar e a distração e garantir o desenvolvimento de todas as faculdades do educando: "fazei-a alternadamente observar, anotar, experimentar, desenhar, construir, discutir, resumir oralmente, redigir, corrigir, e as horas passarão rápidas e alegres" (FERRIÈRE, 1934, p. 110).

Ao mesmo tempo em que a atividade festiva deveria ser interessante, por ser uma atividade diferente das rotineiramente realizadas no cotidiano escolar, esperava-se que essas garantissem o interesse para outras questões escolares. Não era incomum, em manuais escolares escritos por educadores no período da investigação (1890-1930),

\footnotetext{
${ }^{43}$ Apesar de parecerem acepções opostas à associação entre a liberdade das crianças e a disciplina escolar, foi uma das inovações propostas pela escola nova, que previa o uso de estratégias psicológicas para a contenção dos comportamentos dos alunos e, como uma dessas estratégias esteve a questão do interesse e da atividade dos alunos. As crianças interessadas e ativas se comportariam de forma adequada ao seu aprendizado e desenvolvimento.
} 
orientações sobre as formas de organizar as festas e a utilidade que as mesmas possuiriam para o desenvolvimento do processo de ensino. A recreação não deveria ser o único fim da comemoração, mas também o ensino, e "isto obriga o professor a uma escrupulosa seleção dos motivos das festas. Devem merecer preferência os motivos patrióticos, morais e sociais, ficando em segundo plano, os de natureza científica, técnica etc" (LAGE, 1945, p. 203-204). As festas garantiriam, desse modo, suas funções pedagógicas, "visto proporcionar uma excelente oportunidade de ensinar muitas noções úteis, a rir, a brincar ou a cantar" (VIANA, 1946, p. 396-398). Durante o período de preparação das festas, os educandos poderiam aprendem literatura, história e geografia “(matérias relacionadas com as poesias, monólogos, diálogos, etc., que fazem parte do programa); música (pelo menos educam o ouvido); estudariam a pronúncia exata das palavras, e até poderiam adquirir maneiras menos grosseiras" (VIANA, 1946, p. 396398). Ou seja, é possível assinalar que o conceito de festa, para os escolanovistas, era composto das suas duas funções principais: recreativa e pedagógica.

Em qualquer modalidade de festas, quer se tratassem de recitativos, números corais, pequenas representações, comemorações etc., o aluno já teria um comportamento melhor do que o dos recreios escolares. Nestas ocasiões, ele sentiria a responsabilidade de ter de mostrar as habilidades adquiridas nos ensaios, e demonstrá-las de forma satisfatória para o público que o prestigiava. Os professores, sabendo aproveitar este fato, conseguiriam, até mesmo nos casos de alguns alunos cujo interesse pelo estudo era fraco, a melhora substancial do desempenho escolar. Para isso, bastaria que os professores soubessem equilibrar o interesse dos alunos e o aprendizado por meio das solenidades, não consentindo que o interesse pela festa se sobrepusesse aos estudos.

O professor que organize qualquer festa escolar, deve dispor de três qualidades fundamentais: paciência, prudência e persistência. A festa escolar deve dignificar a Escola; de maneira alguma deve transigir com os gostos da multidão, caindo na palhaçada ou na bobice. Por outro lado, os programas devem ser curtos. Os pedagogos recomendam festas que não excedam cinqüenta minutos. É preferível efetuar três ou quatro festas pequenas, do que uma festa de três ou quatro horas. Em conclusão: 'a festa escolar é um meio de ação que oferece um certo interesse, mas do qual não convém abusar'. (LOUREIRO, 1950, p. 209-211, itálicos do autor).

A retomada de alguns dos argumentos elaborados no âmbito da pedagogia renovada acerca do processo de ensino e aprendizagem corrobora a tese das festas escolares como atividades educativas, e não somente de divertimento escolar. É possível perceber em teorias, como a importância do interesse do aluno para a eficiência do 
aprendizado, da atividade como o centro do processo educativo, da concepção de educação na sua funcionalidade, da corresponsabilização dos educandos pelo sucesso do ato festivo, da aproximação sociedade e escola, das relações entre os saberes curriculares e os diferentes modos de ensiná-los, as etapas e os programas, os tempos de realização, a periodicidade, a participação das crianças, os conteúdos e comportamentos a serem aprendidos, distintos elementos capazes de delinear o projeto pedagógico das comemorações no âmbito escolar.

\section{3 - O teatro da festa e o seu aprendizado social}

Contrapondo-se ao modelo escolar tradicional, que enfatizava o individualismo e a competição entre os educandos, a Escola Nova almejou reforçar o coletivo e a solidariedade escolar: “(...) quer que a criança junte os seus esforços aos dos seus companheiros, avalie a força moral enorme que deriva do trabalho em comum, do auxílio mútuo, da cooperação escolar” (FERRIÈRE, 1934, p. 74). As experiências que os educandos possuiriam fora do ambiente institucional, na sua vida social, deveriam relacionar-se no ambiente escolar; conhecendo este meio social o educador garantiria as melhores condições de educar as crianças na escola. Os ambientes imediatos e singulares que circundavam a vida de cada criança, a família, e depois, o meio social, deveriam ser elementos bem conhecidos e explorados pelo mestre (PLANCHARD, 1942, p. 195). Na verdade,

(...) sem uma convergência de esforços pela causa comum, efêmeros e falazes serão os resultados alcançados na escola e no lar. Para que a educação, que a escola se propõe a dar, necessário é que a família se disponha sinceramente a auxiliar os esforços do mestre, bem como a educação doméstica das crianças, só atingirá a plenitude de seu desenvolvimento com a educação escolar, que deve completar a ação paterna começada no berço e continuada muito tempo além pela juventude adiante. A família e a escola são duas forças que se devem completar uma a outra na nobilíssima tarefa de dar à pátria cidadãos de caráter e mães de família exemplares (Revista de Ensino, junho de 1912, p. 41$)^{44}$.

A expressão 'teatro da festa' foi utilizada aqui com o objetivo de marcar as relações entre a escola e a sociedade. A escola prepara a festa para si e para se apresentar para o outro, no caso, a comunidade envolvida pela instituição e, neste caso,

\footnotetext{
${ }^{44}$ Trata-se do discurso do inspetor escolar B. M. Tolosa, por ocasião da inauguração do estandarte do $2^{\circ}$ Grupo Escolar da cidade de Taubaté.
} 
o teatro precisa ser ensaiado para estrear nas suas melhores condições. O aprendizado considerado ao mesmo tempo individual, o desenvolvimento psicológico de cada educando, e social, a sua vida fora da escola, aproximar-se-ia, assim, do contexto sóciohistórico no qual viviam os educandos. Tudo deveria ser aprendido de forma que existisse sentido e que cumprisse uma necessidade do aluno, ou seja, que fosse contextualizado; somente dessa forma o educando tornar-se-ia o agente da sua própria educação, já que "quem recebe a educação é ao mesmo tempo objeto e sujeito de educação. O educando é o principal colaborador ativo da sua educação" (LIMA, 1914, p. 19). A percepção das necessidades e a adequação dos projetos escolares às crianças prescindiram de uma compreensão mais ampla da vida delas, não somente no contexto escolar, mas também no social. A busca de elementos na vida fora da escola para a proposição de atividades seria uma constante nas práticas que se quisessem renovadas de ensino.

Os princípios do método ativo, segundo Adolpho Lima (1914), poderiam ser resumidos em: genético, funcional e social. Estes princípios, orientadores dos métodos e processos, solicitariam dos professores a consideração do educando como agente, e que eles ocupassem uma posição secundária, agindo como vigilantes do trabalho de cada aluno. O método ativo faria do aluno um companheiro dos educadores, e o ensino obra comum destes dois agentes (LiMA, 1914, p. 18). Caberia aos educadores provocarem nos educandos o interesse, despertar-lhe a iniciativa, "inspirar-lhe a confiança em si próprio, impulsioná-lo a experimentar e avaliar as suas forças, habilidades", de modo que criasse em cada um "a necessidade de ser ativo, de ser trabalhador, de ser perito" (LIMA, 1914, p. 19).

Interesses sociais, porém, exercem uma vigorosa influência no indivíduo. É por eles que o nosso interesse direto se transfere para o cumprimento do que é exigido moralmente (DEWEY, 1978, p.158).

O aprendizado de como a sociedade se organizava institucionalmente aconteceria nos momentos festivos pela consciência compartilhada que à sociedade pressupunha, e por meio de "uma participação inteligente na atividade coletiva", que permitiria "uma compreensão comum" (DEWEY, 1978, p.11) do meio em que se vivia, das regras que formam os comportamentos e das representações coletivas que permeiam os imaginários. A continuidade da sociedade se asseguraria não somente por transmissão mediante comunicação, mas sua própria existência se traduziria em transmissão e em comunicação. No caso das festas, tratava-se de um ritual que estaria 
presente nos grupos humanos desde tempos remotos, sendo atribuídos diversos sentidos e funções, que deveriam ser apreendidos pelos mais jovens. Assim, na escola, as festas aprendidas como parte da experiência da vida em sociedade, assegurariam a inclusão, a continuidade e a coesão social.

O fim da educação é, de modo geral, levar os educandos a ter as mesmas idéias que prevalecem entre os adultos, e, assim, como membros reais do grupo social, dar às coisas e aos atos o mesmo sentido que os outros (DEWEY, 1978, p. 24).

A instituição escolar, ao garantir o envolvimento dos pais, representantes da sociedade nas atividades escolares, maximizaria seu potencial pedagógico no âmbito social. Ao mesmo tempo, deveria aproveitar tais situações para demonstrar aos alunos, o papel da educação em determinada comunidade, o lugar ocupado pela escola e pela atividade escolar em um contexto mais amplo de sociedade. Divulgava-se que uma formação integral do educando que almejasse o preparo para a vida autônoma em sociedade (DEWEY, 1978). Para Lourenço Filho (1963), se era necessária a relação entre os indivíduos e objetos nos processos de ensino, era ainda mais significativa a relação entre as pessoas, suas ideias e sentimentos, bem como a consideração das situações e experiências pelas quais passaria a criança nas suas fases sucessivas de desenvolvimento, que aconteceriam individualmente e, também, na interação com as pessoas, suas idéias e seus sentimentos. A partir de tais considerações, seria possível à criança desde tenra idade, identificar seus interesses com os dos outros: "desse modo, importam as matérias de ensino, teóricas e práticas, como súmulas do que pensa o meio social e dos instrumentos que o meio social empregue" (LOURENÇO FILHO, 1978, p. 218).

Quando se trata do desenvolvimento dos sentimentos sociais e morais, a necessidade de fazer da educação uma vida é maior ainda do que quando se trata da cultura das funções intelectuais. Porque é aqui, sobretudo, que a regra não deve aparecer como estranha à vida da criança, como uma inimiga que vem se opor a seus desejos egoístas, podendo fazer dela um eterno revoltado. Para evitar esse perigo é mister socializar a vida escolar, de modo que a necessidade de cooperação e de solidariedade desperte (CLAPARÈDE, 1933, p. 248249).

Não há como negar que a festa foi, e ainda é, uma experiência marcante na vida escolar, seja pelo simbolismo que ela representa (acontecimentos, heróis e signos), seja pela interrupção das atividades e lições cotidianas, pela sensação real ou fictícia de liberdade e divertimento que ela proporciona, ou ainda pelos ensaios que requerem a sua 
preparação. Pode ser entendida como um projeto que, ao ser desenvolvido pelos alunos auxiliados pelos seus professores, garantiria a aquisição de conhecimentos práticos, neste caso, os adquiridos pela necessidade de realizar um evento. Para os alunos, tratava-se do momento de expor-se bem e ter reconhecido todo o seu esforço no âmbito escolar, configurando-se em uma boa oportunidade no qual, o educando deixaria a passividade habitual da sala de aula, para assumir uma postura ativa e ser o protagonista da sua própria atividade, assim como desejavam os escolanovistas.

O educando não aprende por aprender, não estuda porque o $S r$. Professor lhe disse que estudasse, não toma conhecimento de um fenômeno sem que venha a propósito, sem que lhe seja preciso para alguma coisa imediata. O saber não é adquirido por meio de lições sem objetivo evidente, mas com uma finalidade. O aluno não dá a sua lição por somente o Sr. Professor a ter passado (LIMA, 1914, p. 76).

As explicações sobre as formas pelas quais os indivíduos aprendem, e as diferenças que poderiam ser elencadas acerca do aprendizado real e fíctício, perpassaram as teorias elaboradas por quase todos os pedagogos renovados investigados nesta pesquisa. Foi necessário um esforço de compreensão da mentalidade infantil e de seu desenvolvimento cognitivo, físico e moral, para a adequação das metodologias propostas ao ideal de ensino renovado. Neste sentido, práticas antes desconsideradas, como os jogos e as comemorações, passaram a ser percebidas no âmbito da escola nova como atividades capazes de mobilizar saberes tanto escolares quanto sociais. A conciliação entre a escola e a vida, segundo Claparède (1933), se faria por meio do jogo, concebido como atividade social amplamente conhecido. No âmbito dos ensinamentos da psicologia da criança, o educador deveria saber que o jogo figurava como uma das principais necessidades da criança, sendo mesmo, essencial à sua natureza. A necessidade de jogar vai nos permitir, precisamente, reconciliar a
escola com a vida, fornecer ao aluno os móveis de ação que se
pretende impossíveis de encontrar na sala de aula. Qualquer que seja a
tarefa que quereis que a criança execute, se encontrardes o meio de
apresentá-la de modo que seja percebida como um jogo, será
suscetível de libertar em seu proveito tesouros de energia
(CLAPARÈDE, 1933, p.191).

As festas escolares entendidas como jogos de teatro possibilitariam ensinamentos para além do âmbito da sala de aula e do currículo escolar; a formação mesma de um habitus de aluno. Eram eventos escolares capazes de condensar os opostos, realizadas não somente pela atividade infantil, mas também, e disso também dependia o seu sucesso, da passividade dos educandos. Atividade e passividade dos 
presentes seriam os motores e os freios destas ocasiões. Em um momento, o aluno seria chamado a participar, se envolver e realizar determinada parte da festa para, em um momento seguinte, conter-se e absorver o máximo possível dos conhecimentos proferidos por meio dos discursos que eram pronunciados. Prevalecia "o máximo de responsabilidade, de ocasiões para escolher, de auto-direção (self-direction)...” (DEWEY, 1978, p. 242) ao lado da contenção de gestos e palavras.

Os caprichos e os desejos egoístas da criança cederão bem mais facilmente diante das exigências inerentes ao trabalho que ela própria escolheu, do que as solicitações exteriores, ou a imposições dos adultos. Desta maneira, a criança descobre uma espécie de disciplina impessoal, imanente, a única verdadeira, a única que conduz à autêntica liberdade, a do espírito (LEMOS, 1928, p. 44).

Infere-se, a partir dos conceitos mobilizados, que os alunos bem preparados para a ocasião festiva saberiam o exato momento de falar, cantar, declamar, apresentarem-se e calar; saberes festivos que poderiam, ou não, ser percebidos pela plateia que os acompanhavam, mas que comporiam a organização da festa e deveriam ser reconhecidos pelos professores no momento oportuno. Ao mesmo tempo em que a escola mobilizaria a atividade da criança aproximando-se do ideário escolanovista, também restringiria sua participação, aproximando-se assim do tradicionalismo. Aí, localizamos a ambiguidade da atividade festiva. À responsabilidade do aluno pela sua formação e atuação na festa, poder-se-ia acrescer a sua capacidade de reter passivamente o que era ensinado. Concebia-se, assim, o teatro da festa, onde tudo deveria ser ensaiado exaustivamente em várias oportunidades escolares para a grande estreia! As comemorações colocaram em evidência, de forma mais ou menos fundamentada, afinal, a adesão aos princípios da escola nova obedeceu a ritmos de elaboração e de aderência diferentes nos dois países, a questão da centralidade da criança, da garantia do seu interesse, da sua ação efetiva nas atividades escolares e da importância da relação meio social e escolar como paradigmas fundamentais para a organização de qualquer evento festivo.

\section{4 - Os saberes discentes nas festas - a constituição do habitus dos alunos e o aprendizado do currículo escolar}

Ao tratar dos conceitos saberes e fazeres dos alunos almejou-se identificar as representações dos conhecimentos e das ações associados aos eventos festivos e que 
deveriam ser conhecidos pelos mesmos. Tratou-se de investigar, considerando as limitações que as próprias fontes impuseram, as formas pelas quais os alunos vivenciaram a atividade festiva, os saberes exigidos para a sua preparação e os conteúdos divulgados nas suas apresentações. Preparar-se para as festas tornou-se uma das atribuições das crianças frequentadoras das primeiras instituições de ensino consideradas de massas, e passou a fazer parte do seu habitus escolar, concebido como um conjunto de disposições adquiridas pela aprendizagem implícita a partir das ações escolares não previstas oficialmente, ou explícita nos currículos e programas formais que funcionaram como um sistema de esquemas geradores de estratégias para a compreensão e explicação do mundo social (BourdieU, 1983; PERRENOUd, 1995). Fazer parte e contribuir para a elaboração de uma cultura escolar exigiu das crianças o estabelecimento de um sentido ao trabalho que ali se realizava, das suas regras e dos seus saberes, isto é, a (re)organização de um sistema de esquemas de percepção, de pensamento, de avaliação e de ação, que permitiram-nas tirar o máximo possível de lucro das tarefas escolares. No caso das solenidades escolares, e considerando as aprendizagens "escondidas", destacaram-se dois saberes que favoreceram a regularidade do funcionamento da escola e dos seus rituais: aprender, por meio da avaliação ou outros tipos de reforço, a satisfazer as expectativas dos professores e dos colegas, para lhes obter estima, elogios ou outras formas de recompensa e premiação; e aprender a viver em uma sociedade hierarquizada e estratificada, isto é, "viver como normais e legítimas a desigual distribuição do poder e a existência de indivíduos ou grupos de estatutos diferentes" (PERRENOUd, 1995, p. 58).

Cabe assinalar, entretanto, que a presença das crianças/escolares nas solenidades públicas, aconteceu em período anterior ao estudado nesta tese, de forma apartada das finalidades pedagógicas institucionais. No decorrer da história da humanidade, às crianças era indicada a participação nas festas do povo, fossem elas religiosas ou cívicas; não existiam interdições ou recomendações especiais, elas atuavam como os adultos, assistindo aos espetáculos e assumindo um ou outro papel, mas de forma coadjuvante e não condicionada ao seu aprendizado escolar, exceto nas experiências relatadas em internatos particulares do período imperial, como foi o caso do Ateneu (CRESPO, 1990; GALlegO, 2008).

A partir de estudos que se dedicaram a coleta e análise de relatórios produzidos por professores e inspetores em períodos anteriores (1846-1890), no caso brasileiro não há indícios de que os dias destinados às comemorações oficiais ou religiosas tivessem 
espaço próprio no domínio das escolas públicas por meio de atividades dirigidas especificamente para isso: "o lugar de comemorar e os modos de fazê-lo eram reservados e vividos no âmbito público" (GALLEGO, 2008, p. 112); não foram registradas informações nesses materiais que indicavam que os professores tivessem que dar um tratamento pedagógico às datas comemorativas, fato que mudou a partir de 1890, quando as festas "passam a ter como palco as escolas" (idem). Sabe-se que não é possível atribuir somente à mudança de regime político a instituição das festas nas escolas; este processo foi se constituindo no decorrer do século $\mathrm{XIX}^{45}$, e teve a sua consolidação com a escolha da instituição escolar como uma das bandeiras de consolidação do regime político republicano. O conceito de festas escolares estava em processo de elaboração antes de 1889 (Proclamação da República no Brasil) e 1911 (instituição da república portuguesa), mas foi somente com a passagem da responsabilidade pelas instituições de ensino do âmbito religioso para o estatal, com a difusão mundial de um modelo graduado, público e democrático de ensino e a divulgação das práticas renovadas de ensino que se percebeu esforços mais sistematizados para a organização das festas com objetivos pedagógicos no âmbito escolar.

Um dos primeiros objetivos educativos ${ }^{46}$ atribuídos às solenidades no cotidiano escolar relacionou-se à visibilidade que se desejava dar a passagem das crianças para a categoria alunos, e a construção de um habitus do escolar. Eram nestas ocasiões que alguns pais poderiam, pela primeira vez, atestar as transformações dos seus filhos em escolares, e que as crianças presentes, e ainda não matriculadas, poderiam inferir os saberes e comportamentos que lhes seriam cobrados na condição de estudantes. Como uma das condições sociais de "aparecimento da chamada escola nacional" foi a definição do estatuto da infância resultante da combinação de três grandes influências identificadas por Varela e Alvarez-Uria (1992) como: a ação educativa institucional exercida em espaços específicos para isso, dentre outros, os colégios, os albergues, as casas de doutrina e os seminários; a ação educativa da então denominada "família cristã”, única responsável pela instrução das crianças até então e, por último, a contribuição de ações educativas mais difusas associadas às práticas de recristianização

\footnotetext{
${ }^{45}$ Têm-se notícias da participação de escolares nas celebrações dos colégios jesuítas e ainda em colégios particulares do período imperial; por exemplo, as festas realizadas no colégio Ateneu e descritas no romance homônimo de Raul Pompéia $(1888,1998)$.

${ }^{46}$ Utiliza-se a acepção educativa para aludir aos propósitos mais abrangentes das comemorações relacionados aos contextos sociais e históricos. Por outro lado, os objetivos pedagógicos restringem-se aos aprendizados cognitivos e comportamentais dos alunos por meio das mesmas.
} 
das sociedades. Ao selecionar tais influências, Varela e Alvarez-Uria (1992), identificaram as disputas de poder entre os cristãos e os protestantes ${ }^{47}$ ocorridas no século XVI como o período histórico que permitiu a organização das primeiras características que, retomadas e reformuladas posteriormente, definiriam o período da “infância”.

A conceitualização pormenorizada da infância, suas etapas e particularidades teriam que esperar ainda dois séculos e os estudos de J. J Rousseau (século XVIII) para que este corpo de saberes se consolidasse. No século XIX, as investigações acerca das categorias infância e alunos beneficiaram-se dos estudos psicológicos que, associados aos educacionais, fundamentaram uma série de práticas pedagógicas a serem engendradas de acordo com a especificidade do desenvolvimento do ser humano na sua fase infantil. Diferentes dos adultos, os discursos pedagógicos considerados modernos propuseram ações pedagógicas diferenciadas para as crianças baseadas em suas atividades, interesses e no caráter lúdico que permeavam essa etapa da vida. Aulas ao ar livre, excursões escolares, lições de coisas, aplicação de ideias abstratas em experiências de ensino concretas, exercícios físicos ao ar livre, atividades lúdicas e criativas, como poderiam ser caracterizadas as festas, foram alguns exemplos da metodologia renovada em constituição (ClAPARÈDE, 1933; FERRIÈRE, 1934; DEWEY, 1936, 1978; LOURENÇO FILHO, 1963; VIANA, 1946; LOUREIRO, 1950) ${ }^{48}$.

Concebida como uma atividade educativa lúdica e criativa, garantidora das atividades e interesses dos alunos e, também, como uma alteração necessária da rotina escolar, as festas exigiram um conjunto de saberes e fazeres discentes específicos, para além dos currículos propostos oficialmente. Antes de nos demorarmos na apresentação dos saberes e fazeres discentes associados às comemorações no âmbito escolar faz-se necessário elucidar melhor qual foi o discurso pedagógico que justificou a realização deste tipo de atividade, e a possibilidade de aprendizado por meio deles em um duplo movimento: primeiro, de associação desse objeto ao processo de constituição dos sistemas estatais de ensino e, segundo, mediante a análise da sua presença nas

\footnotetext{
${ }^{47}$ Os indivíduos de tenra idade tornavam-se alvos privilegiados de assimilação das distintas ortodoxias e, ainda deveriam ser objetos de cuidados devido a sua fragilidade biológica e seu incipiente processo de socialização; tornavam-se, assim, aptos para serem objetos de inculcação e de moralização dos reformadores católicos (VARELA E ALVAREZ-URIA, 1992).

${ }^{48}$ Foram essas mudanças, que alteraram a escola primária no final do século XIX, aproximando-a das finalidades do ensino secundário, transformando em "educação" e em "formação de espírito" o que antes era "instrução" e "aprendizagens elementares", que conceituam definitivamente o termo aluno no ensino primário (CHERVEL, 1990).
} 
argumentações concernentes aos princípios renovados de ensino mobilizados nestes discursos.

\section{5 - O papel das festas nos sistemas de ensino estatais: a disciplinarização e a moralização da infância}

Foi ideia corrente entre os educadores e reformadores da instrução que atuaram no campo educacional em finais do século XIX e início do XX, a possibilidade de consolidação dos projetos políticos para a área educacional por meio da visibilidade social permitida pelas festas. Associado aos ideais políticos, o conceito de escola moderna deve ser entendido no contexto ao qual o "poder político liberal transferiu para os espaços de socialização escolar o essencial das tarefas destinadas à efetivação das “categorias modernas de pessoa e de cidadão" (Ó, 2003, p. 13); no percurso escolar "o homem novo seria formatado nos ideais do humanismo, das luzes, do progresso, da autonomia e da responsabilidade pessoal" (idem, ibidem). Por meio das festas era dado a ver tudo que estava sendo realizado no âmbito dos sistemas de ensino, como será explorado mais adiante nas situações das festas de aniversário, inauguração e encerramento do ano letivo, bem como às condições do desenvolvimento escolar infantil. Aos objetivos mais externos de apresentação do aparato escolar que ganhava novos contornos somaram-se outros, associados aos aprendizados possibilitados aos alunos pelo planejamento e execução das comemorações escolares.

O projeto modernizador de educação que ganhou corpo com a organização dos sistemas estatais de ensino trocou as práticas de inculcação de conhecimentos, de valores e de ações, característicos do que se convencionou denominar ensino tradicional, pela ideia da ação, que concebeu a constituição dos indivíduos e de sua subjetividade por meio das ações dos mesmos indivíduos. O caráter passivo do ensino foi revisto e reformulado para a vivência de situações escolares que demandaram maior atividade dos alunos, capazes, em última instância, e de acordo com os pensadores renovados, de fabricar atores-sujeitos condutores de sua própria educação. Para atingir esses objetivos, as instituições de ensino criaram para si uma multiplicidade de jogos estratégicos e de situações relacionais, nas quais cada membro da população escolar foi convidado a "constituir-se a si mesmo como um indivíduo autônomo, racional e, uma vez já fora da escola, capaz de dar o seu contributo particular para a integração moral de todo o tecido social" (Ó, 2003, p.03). À existência passiva convencionalmente aceita e 
construída de forma meticulosa nos séculos anteriores, acrescentou-se outra, mais ativa dos alunos na viragem do século XIX ao XX; tais comportamentos ativos e passivos coexistiram no contexto escolar, e puderam ser atestados em diferentes partes dos programas festivos descritos. Caberia perguntar, neste momento, como as comemorações compostas de uma série de esquemas, programas, técnicas e disposições foram concebidas, operacionalizadas e transformadas, com fins de formação da identidade e da conduta das crianças, constituindo-se exemplos significativos de realização da premissa moderna de ensino de condução das condutas dos alunos, sem violência ou punição, mas pela disciplina interiorizada. Em outras palavras, como elas contribuíram para a formação das identidades e dos comportamentos dos alunos na interação com a construção das subjetividades em um projeto comum de ensino?

A consideração do momento festivo como o de expressão máxima das disciplinas aprendidas na escola, tanto as curriculares quanto as comportamentais, merece algum detalhamento. Fazendo um esforço imaginativo, seria possível ao leitor ouvir, em um das salas de aula das escolas primárias portuguesas ou brasileiras de finais do século XIX e início do XX, os professores alertarem os alunos acerca da realização perfeita dos trabalhos escolares e da conduta correta que porventura poderiam ser demandados nas situações públicas das solenidades escolares. Tratava-se de operar um dispositivo disciplinador não mais calcado nas ideias de punição ou violência; aliás, foi bandeira dos pedagogos renovados, a eliminação dos castigos físicos das escolas, mas de um conjunto de técnicas mais refinadas fundamentadas na ideia da disciplina espontânea e autônoma e da persuasão. No plano intelectual, de aprendizagem dos conteúdos escolares, o aluno seria levado a valorizar o estudo e a refletir por si próprio, fundamentado-se nos constantes apelos ao trabalho pessoal, livre e voluntário; no plano moral, o sistema de recompensa material/punição corporal foi trocado pelas estratégias de responsabilização direta, afirmando como possibilidade de recompensa maior dos trabalhos educativos, a satisfação das inclinações mais elevadas das crianças, fornecendo-lhes "a garantia antecipada de que cada um será capaz de vencer a si próprio" (Ó, 2003, p. 122).

No também designado 'século da criança', a disciplina é, de fato, um exercício crescentemente solitário e associado à independência ideal do aluno: as regras que permitem a vida coletiva já não se impõem pela violência das sanções, pela rigidez dos princípios, e nem sequer são passíveis de ser ensinadas pelo professor; inversamente, cada um está obrigado a inferi-las, a descobri-las num jogo relacional com o mundo exterior - onde é claro a velha lógica da emulação e do 
mimetismo identitário mantém muito do seu êxito socializador -, mas que deve ter a sua origem e o seu termo dentro dos limites do sujeito (idem, p. 112).

De acordo com Ó (2003), a moderna escola de massas, em processo progressivo de consolidação desde a segunda metade do século XIX, pode ser concebida como outra expressão, dentre várias, das práticas das "tecnologias do governo da alma", evidenciados nos projetos de uma administração política e disciplinar do tecido social (Ó, 2003, p. 104). O discurso pedagógico projetou um tipo ideal de estudante, independente e responsável, capaz de medir as consequências, tanto dos seus atos, quanto dos seus comportamentos, através de regras exteriores introjetadas e resultantes das suas experiências pessoais de adaptação espontânea à vida escolar, concebida como microcosmo da vida social (DEWEY, 1936; 1978). O grande desafio colocado aos professores e às instituições de ensino foi criar situações nas quais os alunos pudessem exercitar valores como autonomia, liberdade e responsabilidade, dentro dos limites institucionais permitidos, como foi o caso das comemorações escolares.

As festas engendradas para promover a autonomia, a liberdade e a responsabilidade dos alunos também se constituíram enquanto importantes dispositivos disciplinares. A liberdade e a autonomia dos alunos foram exercitadas nas etapas preparatórias das comemorações e na sua concretização, desde que elas seguissem programas previamente formulados pelas instâncias superiores de ensino ou reconhecidos por elas, utilizassem contos, histórias e poesias presentes nos materiais didáticos, ensaiassem apresentações musicais preferencialmente de cariz patriótico e atuassem em peças teatrais com histórias moralizantes. A característica disciplinadora das comemorações residiria, inicialmente, no controle externo realizado pelos responsáveis pelo ensino, evidenciado, por exemplo, na indicação das datas, de heróis e de fatos a serem solenizados, bem como nas prescrições descritas nos programas das festas e, de forma mais implícita, na incorporação de regras, saberes e ações escolares de maneira ativa pelas crianças. Neste sentido, a transposição das festas realizadas nas esferas públicas para o contexto escolar, associadas em algumas situações à livre expressão de paixões, desejos e instintos dos indivíduos, passou por um processo de esquadrinhamento e reajuste aos propósitos do ensino e da disciplina escolar.

Vagar, correr, pular, brincar, xingar e brigar desordenadamente incomodava diretores e inspetores que viam nesses comportamentos dos alunos um grande prejuízo para os bons costumes. Por isso, a 
necessidade de vigilância permanente, de disciplina insidiosa, de aproveitamento máximo do tempo (SoUZA, 1998, p. 147).

Ao seguir programas, dias e ciclos predefinidos, as festas puderam incitar os valores da ordem e da regularidade, indicando aos alunos a importância de seguir as regras definidoras das organizações sociais. Essas regras permearam o funcionamento das escolas primárias desde a sua institucionalização. O dispositivo escolar, assim como definiu Fernandes (1994), foi todo montado para obrigar à criança à existência sob regras, tais como, comparecer às aulas com regularidade, em horário predeterminados, demonstrando atitudes convenientes, sem perturbar a ordem e realizando suas lições com aplicação. A obediência às regras escolares tornar-se-ia uma iniciação ao comportamento que deveria ser apresentado socialmente; era um mecanismo pedagógico capaz de "constituir na criança aquilo que lhe faltava, o Outro internamente inscrito e dominante" (FERNANDES, 1994, p. 147, itálico da autora). Neste sentido, cabe destacar que todos os regulamentos da instrução pública paulistas do período entre 1890 e 1910, reafirmavam que "a disciplina escolar deveria repousar essencialmente na afeição do professor para com os alunos, de modo a estes serem dirigidos, não pelo temor, mas pelo conselho e pela persuasão amistosa (Decreto $n$. 248, de 26.7.1894)" (SOUZA, 1998, p. 147).

A livre expressão dos alunos encontraria seus limites nas regras que organizavam a vida escolar e, no âmbito destas, das atividades festivas. Neste sentido, o caráter e a própria liberdade da criança seriam desenvolvidas pelo instrumento "mais poderoso" que a educação tinha ao seu dispor, o hábito; habituando-se a agir e pensar corretamente sob as regras dispostas (Ó, 2003), primeiro na escola e depois, na sociedade.

Nada mais belo do que uma festa de crianças das escolas, reunidas em um jardim ou em um parque, sob às vistas dos professores, ora obedecendo à disciplina a que se habituaram nas classes, ora em plena liberdade entregando-se aos folguedos próprios da infância e confraternizando com os coleguinhas de outras escolas" (Revista de Ensino, Julho de 1906, p.781).

As situações festivas reorganizaram os saberes disciplinares buscando por meio deles a moralização da infância. Este primeiro elemento da moralização, a disciplina, permitiria que os comportamentos dos alunos, ao penetrarem na "maquinaria escolar" (VArela, J.; AlvareZ-Uria, F., 1992), fossem refeitos segundo um código: as boas tendências eram reforçadas e transmutadas em espírito de disciplina; as más tendências, 
transformadas em faltas (FERNANDES, 1994). Boas e más tendências cujas definições poderiam variar entre os autores e professores do período. O segundo elemento da moralidade, de acordo com Fernandes (1994), é a vinculação a um grupo social, por exemplo, a pátria, entendida como um dos “órgãos através dos quais se realiza a ideia de humanidade" (idem, p. 179), também possível de ser concretizado nas situações festivas. Nestas, as ações, hábitos e pensamentos organizados coletivamente, seriam capazes de gerar o "gosto da vida coletiva" capaz de ligar os alunos aos fins coletivos (FERNANDES, 1994).

O sentimento de pertinência coletiva segundo laços de sociabilidade diferentes, mas harmônicos, amplia-se concentricamente num percurso no qual a escola, elo intermediário, é uma etapa da preparação antecipada à sociedade política (FERNANDES, 1994, p. 184).

A moralização da população escolar aconteceria mediante a criação do "espírito da disciplina" nos alunos. Era necessário que eles compreendessem a importância das regras, e sentissem "o gosto da regularidade e da autoridade". A existência sob regras fazia parte do código dos deveres escolares a serem aprendidos pelas crianças; a moralidade seria inscrita na criança devido a um dispositivo pedagógico que a acolheria e a enquadraria em um grupo social, de modo que elas pudessem experienciar e reforçar um modo de ser escolar que influenciasse sua vida adulta. Compreende-se, assim, o segundo elemento da moralidade como a vinculação a um coletivo, considerando o grupo em si mesmo e, enquanto tal, peça essencial do dispositivo disciplinar (CHERVEL, 1990). Por fim, habituados ${ }^{49}$ aos códigos disciplinares, e a pensar e agir coletivamente, os alunos seriam capazes de gozar de sua autonomia da vontade, considerado o fim último do processo educativo (FERNANDES, 1994), traduzindo a palavra moral como vontade e governo de si (Ó, 2003).

Ao relacionarem-se às disciplinas escolares e comportamentais dos alunos, as festas escolares, organizadas em regras e códigos, contribuíram para o ensino e o aprendizado de um conjunto de saberes associados à vida escolar e social. Ao mostrar a disciplina comportamental, e prescindir das disciplinas escolares, compreendidas como os modos de transmissão cultural que se dirigem aos alunos (CHERVEL, 1990), as situações festivas permitiram ainda, a moralização da infância e da população que delas

49 De acordo com Ó (2003), o caráter e a própria liberdade da criança seriam desenvolvidas pelo instrumento "mais poderoso" que a educação tinha ao seu dispor: o hábito. O hábito de praticar o bem transformar-se-ia em uma segunda natureza, identificando-se com a própria subjetividade. 
participavam, ao disseminar valores significativos para a boa atuação escolar e social. Era nestas ocasiões que todo o esforço escolar das crianças era reconhecido, seja pela indicação de partes importantes do programa (homenagens, papéis principais nas peças, destaque nas apresentações de trabalhos), ou ainda, por meio da distribuição de prêmios aos melhores alunos. Como um dos dispositivos pedagógicos modernos, era por meio das comemorações escolares que se ensinariam condutas adequadas, acolhendo e enquadrando os alunos em um grupo social de forma que as crianças pudessem vivenciar um modelo de ser escolares.

A disciplina e a moral escolar recebem novos significados e ações no discurso de renovação do ensino. Se antes, a disciplina era algo a ser imposto pela punição e pelos castigos físicos, e a moral, ensinada pelos dogmas da religião católica, a partir da laicização e do discurso modernizador do ensino seriam necessários novos mecanismos, mais sutis, para as realizações dos mesmos intentos como foram as festas escolares. "A brincar" de preparar as solenidades, os alunos estariam aprendendo. Inicialmente, alguns conteúdos (significados das datas, elaboração de textos para as festas, atuação em peças teatrais, ensaios musicais, entre outros), e de forma implícita, o que significava ser aluno, os valores e comportamentos associados a tal função, bem como a disciplina e a moral exigidas no processo de laicização do ensino. A máquina festiva, nas suas diferentes técnicas e engrenagens, assim como outros dispositivos escolares, estaria a serviço da moral e da disciplina dos alunos.

Ao assumir tal perspectiva civilizadora, a escola recorreu a diferentes recursos didáticos e, dentre eles, podemos citar as festas escolares, que no seu interior engendraram estratégias de controle, instauração, preservação e perpetuação de valores, de tradições, de comportamentos existentes ou pretendidos, de disciplinas, de identidades, de hierarquias, entre outros. Aproximar os alunos destas normas, preceitos e saberes escolares constituiu-se parte do projeto civilizador ${ }^{50}$ da escola também presente nas características pedagógicas das comemorações. As festas como ocasiões que precipuamente associaram-se a ideias de desregulação e espontaneidade, nas escolas adquiriram características disciplinadoras e moralizadoras acentuadas, tornandose momentos de apresentações do controle do corpo e da mente dos alunos. Nessa, o

\footnotetext{
50 Para Boto (2010), o conceito de civilização deve ser considerado no caráter inventivo da cultura escolar e das práticas que originalmente são produzidas no cotidiano da instituição, além disso supõe o caráter de projeto social pressuposto na tarefa de escolarizar, tornando a escola em uma das formas de civilizar.
} 
esquadrinhamento disciplinador se faz presente quando determinava previamente o local de cada um, o papel a ser desempenhado, os diferentes graus de conhecimento, distinguindo os alunos hierarquicamente.

\section{6 - Os prêmios e a coroação dos saberes discentes}

Uma das técnicas recorrentes nas celebrações escolares, cujas justificativas relacionaram-se ao ensino da moral e da disciplina dos alunos, foi a distribuição de prêmios aos escolares nas situações festivas. No discurso educativo moderno, já não existia lugar para os castigos físicos, que deveriam ser substituídos por técnicas disciplinares mais sutis e eficazes como, por exemplo, os cartões de mérito, as notas de aplicação, os quadros de honra e, por fim, os prêmios, que, distribuídos por ocasião dos exames finais realizados pelos alunos e festas de encerramento com a exposição dos trabalhos escolares elaborados no decorrer do ano letivo, significaram o coroamento dos mecanismos de motivação e incentivo escolares (SOUZA, 1998). Os prêmios trariam como vantagem, em um primeiro momento, a emulação dos alunos, que, motivados e devidamente reconhecidos, poderiam promover o progresso da civilização, como explicitou o professor primário de Rio Maior (Portugal), em 1890: “(...) congratulando o colega, felicitando as meninas e pondo em evidência as vantagens dos prêmios à infância estudiosa para o feliz desenvolvimento da civilização e do progresso; que tem a base fundamental na instrução da mocidade" (A Escola: Revista de Pedagogia e de Instrução Pública, agosto de 1890, s.p).

De acordo com outro professor português, o Sr. Cardoso Júnior, os prêmios podem "justificar-se como um estímulo proporcionado às crianças: com a mira nessa recompensa ganharão amor ao trabalho, estarão atentas às explicações e experiências do professor, esforçar-se-ão por ter bom procedimento". Como argumento para o seu uso, retomou exemplos históricos, como o sistema pedagógico dos jesuítas, que os defendiam e aplicavam (A Escola Primária, julho de 1932, p. 101). Entretanto, alguns "bons pedagogistas e os bons pedagogos" se colocaram contra os prêmios, se não fossem dados a todas as crianças, o que poderia originar despeitos e rivalidades entre os alunos da mesma escola ou da mesma classe, ou, "além de estabelecer diferenças entre as crianças, num meio em que elas não devem existir, pode representar uma injustiça que fere o brio e a dignidade dos alunos que não são contemplados" (idem). Neste 
sentido, segundo Cardoso Junior (1932), a tarefa educativa deveria ser orientada de modo que a criança a realizasse sempre "com prazer e tenha como prêmio a satisfação que provem desse prazer". Na opinião do autor, a escola ativa "constituía seguramente, o melhor meio de atingir tal fim, visto que se fundou no respeito pela espontaneidade infantil e pela satisfação da sua necessidade de movimento" (A Escola Primária, julho de 1932, p. 101). E defendia, ao final do seu texto:

Em vez das sessões solenes, com oradores para louvar os premiados, eu prefiro as festas de crianças para crianças, a fim de coroar os trabalhos letivos, e em que se dê a todas as crianças, sem exceção, uma recordação, embora modesta, desse dia de alegria infantil $(A$ Escola Primária, julho de 1932, p. 101).

A escolha e compra de prêmios aos bons alunos era uma das tarefas oficiais dos inspetores de ensino, conforme ficou registrado nos regulamentos escolares (por exemplo, no "Regimento Interno das Escolas Públicas de São Paulo", 1894), que poderiam ser auxiliados pelos professores, e cuja despesa correria por conta do Conselho Superior. Entretanto, tivemos notícias, nas páginas dos periódicos de ensino que, em alguns casos, os professores, sem contar com verbas extras para a preparação das festas ou compra de prêmios, tiveram que retirar partes do seu salário para obter prendas aos alunos que se destacaram no ano letivo, "lastimando não ter bens de fortuna para dar as minhas amadas discípulas prêmios que mais as satisfizesse e para socorrer as maiores necessidades da infeliz instrução primária" (A escola: Revista de Pedagogia e de Instrução Pública, agosto de 1890, s.p). Ou seja, mesmo sem fazer parte das atribuições oficiais regulamentadas por lei, os professores tiveram que se adequar e criar mecanismos outros para a realização de mais essa demanda associada aos rituais escolares: a compra e a distribuição de prêmios aos melhores alunos, sentindo-se até mesmo culpados quando não conseguiam cumprir a contento tal demanda:

Concluo pedindo desculpa do incomodo que causei a v. ex.as para uma festa tão simples e lastimando não ter bens de fortuna para dar as minhas amadas discípulas prêmios que mais as satisfizesse e para socorrer as maiores necessidades da infeliz instrução primária. E por último recomendo, às meninas presentes, que sejão sempre estudiosas, dóceis e comedidas para sua completa felicidade (A escola: Revista de Pedagogia e de Instrução Pública, agosto de 1890, s.p).

Em outras situações, considerando a possibilidade de propaganda política por meio das comemorações, comerciantes e autoridades públicas confirmavam seu interesse na educação, oferecendo prêmios aos escolares, que poderiam ser de dois tipos: a oferta de alguns objetos relacionados à vida escolar dos alunos, como livros, 
cadernos, lápis, medalhas e cartões que, segundo os autores, promoveriam o maior empenho dos alunos na vida escolar ou, uma segunda categoria, localizada especialmente nos periódicos de ensino portugueses (Dia da Boa Vontade e Natal) por ocasião das festas beneficentes, eram relacionados às primeiras necessidades das crianças pobres, como roupas, sapatos e alimentos. Posteriormente, como se investigou para as escolas brasileiras, a prática de distribuição dos uniformes pelas escolas foi institucionalizada pelas Caixas Escolares (SILVA, K.; 2006). Apesar de pertencerem a categorias diferentes, os prêmios funcionaram como o mesmo intento de emulação e como ação de dar e garantir melhores condições, seja de vida na escola ou na sociedade às crianças, de forma mais abrangente, que permitiria garantir a atenção e o interesse que se desejavam às coisas do ensino. $\mathrm{O}$ auxílio das Câmaras Municipais e outras pessoas da sociedade indicaram que a concepção de mérito escolar não se constituía somente uma representação das autoridades e profissionais do ensino, ela era um valor social.

Segue-se a distribuição dos prêmios, que as crianças recebem das mãos gentilíssimas das damas; e quando terminava esta simpática cerimônia (...). A suplementar generosidade de alguns dos presentes aumenta o pecúlio obtido, e foi assim que Sr. Conde de Feitosa distribuiu uma moeda de cem réis a cada pequeno, o Sr. Conselheiro Peito de Carvalho uma moeda de cinco tostões a cada pequena, e que o Sr. Conselheiro Rosado, sua esposa e ainda o Sr. Caetano Pinto gratificaram devidamente os respectivos professores. (A escola: Revista de Pedagogia e de Instrução Pública, agosto de 1890, s.p).

Como maneira de uniformizar as fontes de recursos para a compra e distribuição de prêmios aos alunos recomendados pelos professores, acresceu-se a arrecadação de verbas para a compra desses objetos, conforme constava no noticiário da revista portuguesa, Revista Infantil, de abril de 1922:

(...) Foram enviados pelo Exmo. Sr. Joaquim Gomes Belo, professor da Marinha Grande, os estatutos da Caixa Infantil daquela localidade, cujos fins são: promover festas escolares, exercer a beneficência a alunos pobres, concessão de prêmios, incitamento ao estudo, recreio e desenvolvimento das forças físicas. Conta 200 sócios entre as crianças das escolas do conselho da Marinha Grande (Revista Infantil, abril de 1922, p. 191).

O projeto dos Estatutos da Caixa Escolar, divulgado por Manuel Antunes Amor no ano de 1930, nas páginas da Revista Escolar, indicou a realização das solenidades de final de ano sob os auspícios não somente da escola e dos professores, mas também dessa moderna instituição de ensino. É curioso observar que as Caixas Escolares 
deveriam contribuir com a realização das diferentes festas: das árvores, das aves e das flores, além da compra de prêmios para os alunos.

Art. $2^{\circ}$. Esta instituição tem por fim:

(...)

g) Realizar anualmente exposições dos trabalhos escolares dos alunos, um bazar e festas escolares de educação, tais como distribuição solene de prêmios, saraus literários e artísticos, festas desportivas, festas da árvore, festa da flor, festa da ave etc (Revista Escolar, fevereiro de 1930, p. 114).

Os prêmios, concebidos como forma de emulação e disciplina, reafirmaram, conforme argumenta Souza (1998), os princípios do liberalismo com base na valorização do mérito individual: "a premiação dos alunos mais brilhantes ressaltava a força simbólica de uma cultura escolar que se estava construindo com base na homogeneização e, contraditoriamente, na individualização” (p. 247). Em uma sociedade marcada por forte estrutura hierárquica e por grandes desigualdades sociais, como era o caso da brasileira, era possível explicar porque a ideologia liberal tenha sido tão valorizada nos primeiros anos da república brasileira (SOUZA, 1998).

A distribuição de prêmios aos melhores alunos fazia parte de um ritual que tinha início, de acordo com os regimentos dos grupos escolares paulistas (1894), 21 dias antes das atividades finais do ano letivo, e deveriam se organizar da seguinte maneira: 15 dias para a realização dos exames escritos de algumas matérias do programa pelo diretor da escola, auxiliado pelos inspetores e professores, e sete dias para a realização das solenidades de encerramento das aulas, que constaria de exposição de trabalhos escolares, "inspeção pública das classes, entrega de promoções e diplomas, distribuição de prêmios e excursões campestres" (Anuário do Ensino do Estado de São Paulo, 02, p. 22). A realização de atividades diversas nos dias que antecediam as férias escolares no Brasil marcava o fim de um ciclo escolar que deveria ser avaliado, compartilhado e socializado por toda a comunidade.

Concebidas como um dos dispositivos de normalização e disciplinarização da infância, as comemorações indicaram em seus programas significativas estratégias de emulação ao dedicarem tempos especiais às homenagens realizadas aos melhores alunos por meio da distribuição de prêmios, especialmente nas festas de encerramento do ano letivo, nas quais se realizavam os exames finais e os de mudança de série. A importância dos prêmios não residia no seu valor monetário, mas no simbolismo que tal prática adquiriu no contexto escolar daquele momento em diante. Ser um bom aluno ou 
uma boa aluna, além de fazer um bem para si, significou ter o reconhecimento social e desenvolvido o sentimento de contínuo aprimoramento escolar e social.

\section{7 - Colocar a máquina em funcionamento: as atividades discentes associadas à realização das festas}

Colocar a máquina festiva em funcionamento constituiu-se uma das aprendizagens das crianças matriculadas nas escolas públicas primárias de finais do século XIX e início do XX. Aos estudantes, caberia a participação ativa no preparo da festa e no ensaio dos seus papéis, na organização do programa (indicação dos números e planejamento dos convites) e divulgação deste entre os familiares, além do aprendizado das diferentes funções das festas e dos saberes relacionados a elas (para que serve?; como organizá-las?). Tais conhecimentos eram provenientes de duas fontes: os saberes organizados nas matérias do currículo oficial que, aprendidos previamente e mesmo sem aludirem diretamente a elas, poderiam contribuir para a sua realização, bem como os saberes originários do currículo não oficial ou, como desejam alguns autores, do currículo oculto (PERRENOUd, 1995), que ajudaram na construção dos sentidos e das apropriações dos festejos na sua apresentação. Na segunda vertente se localizariam os conhecimentos relacionados ao cumprimento da própria solenidade, ou seja, aos comportamentos que, ensaiados no cotidiano escolar, deveriam ganhar uma dimensão exemplar, pública e representativa do ofício do aluno (idem) que então se constituía. Como foi indicado alhures, o comportamento do educando nestas ocasiões era diferente, já que ele se apresentava como corresponsável pela atividade festiva e precisava apresentar-se à altura da responsabilidade conferida. A transformação das crianças em alunos pressupôs o aprendizado de uma série de saberes e de estratégias requeridas pela escola; não é por acaso que alguns autores (PERRENOUD, 1995) identificam o trabalho escolar do aluno como um ofício a ser aprendido e aprimorado no decorrer dos anos de escolarização.

O conceito de ofício de aluno, elaborado pelo sociólogo P. Perrenoud (1995) apresentou-se potencialmente fértil para tratarmos das tarefas levadas a efeito pelas crianças no cotidiano escolar, cabendo-nos demorar ainda um pouco mais neste aspecto. Apesar de não receberem uma remuneração pelas atividades realizadas, o conceito ofício de aluno se aplica pela definição de "ocupação permanente que possui algumas 
características de ofício" (PERRENOUd, 1995, p. 15), da qual as crianças e adolescentes retiram os seus meios de subsistência, sendo reconhecidas socialmente e aceitas nessa situação. Concebidas como um ofício, as ações realizadas pelos alunos trariam algumas características que, em processo de elaboração no contexto analisado, tornar-se-iam marcantes na prática discente no decorrer do século XX. Além de não ser remunerado, esse ofício é muito específico, por apresentar as seguintes características: é o menos livremente escolhido pelos alunos, cabe aqui lembrar as discussões que se realizaram nas primeiras décadas republicanas no Brasil e em Portugal acerca da questão da obrigatoriedade escolar, e dos anos de escolaridade necessários para a formação do cidadão; é um trabalho dependente de terceiros nas suas finalidades, condições principais e nos seus detalhes, especialmente com relação ao tempo dedicado a cada tarefa; realiza-se sob o controle de terceiros, no que diz respeito aos resultados e às modalidades. Tal visibilidade ficou muito explícita na situação festiva e, por último, está constantemente sujeito ao princípio de uma avaliação das qualidades e dos defeitos da pessoa, da sua inteligência, de seu caráter e de sua cultura (PERRENOUD, 1995, p. 16).

A retomada do conceito de ofício de aluno serve-nos para problematizar questões em pauta nas disputas entre os modelos de ensino tradicionais e renovados que marcaram o período histórico delimitado e que contribuíram para a percepção de ações contraditórias da festa. Considerando tal ofício como ações organizativas das tarefas dos alunos na escola, discutem-se as ideias de que na escola não se viveria, mas sim, se prepararia para a vida, ou de que o trabalho do aluno não teria um significado verdadeiro, já que não existiria uma remuneração, ou ainda, a ideia de que na escola não há ação, mas sim a preparação para o agir. Ao nos debruçarmos sobre as atividades discentes relacionadas às festas, infere-se a importância do trabalho, da ação e da atividade do aluno sob pena de sua não realização. Essas atividades nos colocam, de forma mais ou menos explícita dependendo das ocasiões, a própria contradição da vida do aluno nesse contexto escolar que, ora foi chamado a tomar iniciativas, se expressar e se apresentar como corresponsável pelas atividades festivas (festas das crianças), ora foi conclamado a participar passivamente como assistente de solenidades preparadas para o mesmo (festejos para as crianças). No âmbito do oficio do aluno, estariam atividades mais tradicionais, como escutar as lições, ler e fazer os exercícios, resolver problemas e, por outro lado, outras mais inovadoras, como fazer pesquisas, realizar projetos e preparar as solenidades, todas com objetivos comuns de estimular a 
compreensão, a memorização e a generalização de certas noções, métodos ou conhecimentos (PERRENOUD, 1995).

Não se pode deixar de ponderar, entretanto, que a relação estabelecida entre os alunos e os saberes escolares foi, e ainda o é, extremamente criativa: as crianças elaboram estratégias de "sobrevivência" no contexto escolar, o que induz, algumas vezes, a uma relação estratégica e utilitária com a escolarização. Nas palavras de Perrenoud (1995), quando o essencial é sobreviver até o próximo período seletivo, a lógica dos alunos pode não ser a de compreender e a de aprender para o seu próprio prazer, por curiosidade ou para satisfazer seus interesses pessoais, mas sim, para "fazer boa figura na competição para obter bons resultados" (p. 22); desse modo, "no ofício do aluno, o artifício e a preocupação com as aparências tem um lugar importante" (PERRENOUd, 1995, p. 22). Não entra em jogo o que realmente foi aprendido por interesse ou motivação própria, mas as formas pelas quais os alunos puderam expressar seus saberes, dando visibilidade às características mais próximas do modelo de "aluno ideal". Quando se propõe a atividade festiva como uma tarefa prazerosa, garantidora do interesse e da supressão das necessidades dos alunos, utiliza-se uma argumentação bastante externa acerca das justificativas para a sua realização, o que nos propõe uma série de indagações: será que todos os alunos sentiram e se apropriaram dos momentos de festa da mesma forma? Tiveram o mesmo interesse e motivação na sua realização? Será que os alunos significaram as solenidades da mesma forma que aqueles que construíram os argumentos para a sua realização? Qual o sentido atribuído às festas pelos alunos? Ou ainda, como se organizou o ofício do aluno nas primeiras iniciativas estatais de organização do ensino, ou mais especificamente, quais tarefas desse ofício se relacionaram aos momentos festivos?

A partir de tais questões, investigaram-se evidências mais externas associadas às tarefas do ofício dos alunos relacionadas à atividade festiva, uma vez mais, considerando a impossibilidade de, por meio das fontes escolhidas, compreender todas as vivências individuais possibilitadas pelas festas. Por meio da análise dos manuais e dos periódicos nos dois países investigados, foi possível inferir um conjunto de informações acerca dos saberes fundamentais do ofício dos alunos para a garantia do sucesso das festas, provenientes das próprias ações inerentes a elas, e atribuídas às crianças, ou seja, as tarefas que somente se realizariam por ocasião das solenidades e, de forma menos evidente, dos saberes presentes nas disciplinas do currículo oficial e que, de maneira mais ou menos incisiva, deram contribuições à festa. 
Entendia-se que as solenidades, concebidas como atividades recreativas, interessantes e prazerosas, poderiam proporcionar às crianças o aprendizado de saberes relacionados aos conteúdos escolares, a partir de um método peculiar pautado nas suas próprias ações, e também na acomodação aos comportamentos desejados, escolar e socialmente. A organização de uma festa envolvia todos os profissionais da escola e seus alunos - os professores coordenando as funções, escolhendo as temáticas dentre as designadas oficialmente e os programas, e os alunos realizando suas tarefas, sendo que "todas as crianças gostam de colaborar nele", além de estudando seus personagens, já que "o desempenho de papéis especiais na festa, constitui o motivo de maior prazer" para os alunos (LAGE, 1945). De acordo com Lage (1945), a criança, quando se dedicava com todo o entusiasmo ao papel que lhe era atribuído, moldava as suas atitudes e corrigia as suas expressões, no desejo de fazer boa figura. Para outras menos interessadas pela aprendizagem, era possível retomar o entusiasmo pelos estudos quando elas se ocupavam de parte dos programas das festas escolares.

Na organização duma festa escolar deverão tomar parte todos os alunos. E para não alimentar vaidades nem quebrar estímulos, não deverá o professor marcar despoticamente atribuições pessoais nos trabalhos de organização. Deixará que a classe se manifeste livremente sobre a distribuição de funções, para ele só depois objetar no que tiver por conveniente. Tendo ouvido as opiniões dos próprios alunos, ficará o professor mais apto a acertar na distribuição dos papéis. Depois duma festa escolar deverá o professor organizar trabalhos práticos com ela relacionados, à maneira do que fez em relação aos passeios e excursões escolares (LAGE, 1945, p. 203-204).

A atividade e participação dos alunos destacaram-se entre as justificativas que fundamentaram a atenção dada pelos educadores para situações de classe consideradas até então pouco relevantes; em outras palavras, a ação dos alunos sobre os seus objetos de aprendizagem. No ideário renovador, destacava-se a consideração da atividade prática do aluno para um aprendizado mais eficaz, pois só assim, “os alunos entram no âmago do processo de aprendizagem” (MATTOS, 1960, p. 284), e poderiam realmente se desenvolver. Era por meio destas atividades práticas, ou de aplicação, que os alunos realmente aprenderiam, "assimilando os pensamentos, adquirindo as habilidades específicas desejadas, e formando atitudes e ideais de vida e de trabalho" (idem, ibidem). De acordo com Mattos (1960) ${ }^{51}$, a importância da prática era fundamental para qualquer tipo de aprendizagem; prova disso, era que a didática moderna lhe reservava

\footnotetext{
${ }^{51}$ Foi Catedrático de Didática Geral e Especial e diretor do Colégio de Aplicação da Faculdade Nacional de Filosofia da Universidade do Brasil, conforme consta na apresentação do seu manual.
} 
sempre entre 60 a $70 \%$ do total de seus preceitos. Seria a fase que, sozinha, ocuparia, portanto, mais tempo no plano didático do que todas as outras reunidas; era também a que mais diretamente afetaria o rendimento escolar.

Dentre as atividades práticas elencadas pelo autor, e que possibilitariam a manutenção do interesse e das ações dos alunos, e estariam mais diretamente relacionadas às festas constam: a preparação de cenários para uma representação teatral ou para uma das festas escolares; a confecção de artigos e maquetes para uma exposição, e trabalhos tais como: tabuinhas cuneiformes, um pergaminho, a maquete de um castelo medieval etc. Além dessas, e a partir das informações localizadas nas fontes, poderíamos acrescentar: a limpeza e decoração das escolas e das salas de aulas; a confecção de figurinos específicos para as peças que seriam apresentadas; o planejamento do espaço escolar ou as adequações necessárias aos mesmos ${ }^{52}$ para a permanência do palco, do público escolar, dos homenageados e da população em geral; os ensaios das músicas, das peças, das declamações de textos produzidos por outros ou pelos próprios alunos, bem como a produção de convites e divulgação dos eventos dentre os familiares e comunidade escolar.

As tarefas dos alunos também se diferenciaram de acordo com os tipos de festejos realizados. Por exemplo: no caso das festas de aniversário e inauguração, foi comum a realização de inspeção ${ }^{53}$ em todos os anos, o que exigiria dos alunos se prepararem para as mesmas; nas comemorações cívicas, aconteciam com grande pompa, o hasteamento das bandeiras nacionais e a execução dos hinos patrióticos, bem como os desfiles pelas ruas das cidades, o que pressupunha o conhecimento do ritual de hasteamento, das marchas e evoluções para as passeatas; já nas celebrações da natureza, especialmente nas dedicadas às árvores, os estudantes realizavam a plantação de mudas em locais previamente definidos, indicando o conhecimento das técnicas de plantio adequadas. As ações, preponderantemente coletivas, indicavam que muito mais do que as habilidades e/ou competências dos professores. As festas prescindiram de um conjunto de atuações ordenadas e conjuntas dos alunos para a garantia do brilho

\footnotetext{
${ }^{52}$ Cabe destacar que o programa arquitetônico básico dos grupos escolares, modelos de instituições no período, restringiu-se a poucos ambientes, que não por este motivo deixou de apresentar monumentalidade e esmero no tratamento das fachadas com grande número de ornamentos: "A maior parte dos grupos escolares de dois pavimentos foi construída como um bloco compacto, com entradas laterais e frontões centrais apresentando uma monumentalidade austera, impactante, com suas amplas e inumeráveis janelas" (SOUZA, 1998, p. 130).

${ }^{53}$ As inspeções escolares, organizadas na década de 50 do século XIX, na província de São Paulo, consistiam em visitas às escolas para verificar as condições de funcionamento destas (materiais e de profissionais) e, algumas vezes, da aplicação de exames aos alunos (GALLEGO, 2008).
} 
necessário ao evento. $\mathrm{O}$ aluno deixava de ser único, na maior parte do programa festivo (exceto nos momentos dos exames), para fazer parte de um grupo representativo da instituição escolar.

Nas escolas progressistas, a tendência atualmente dominante é a de equilibrar essas duas modalidades de trabalho (trabalho individual com o socializado), reservando a cada uma aproximadamente a metade da jornada escolar (MATTOS, 1960, p. 308).

Como atividades realizadas fora do ambiente formal das salas de aulas e das exigências regulamentares dos programas oficiais, afinal, as comemorações não eram consideradas um conjunto de conteúdos curriculares que deveria ser aprendido e depois, devolvido nas situações de exames; elas possibilitaram dirimir o que então vinha sendo criticado como a grande falha da educação tradicional, considerada a ausência da associação entre o intelecto e a prática. Além da ênfase dada à atividade e participação dos alunos, concebidos como elementos relevantes para justificar a realização dos festejos, foram destacados o estímulo às capacidades de criação, autoexpressão, iniciativa, senso de responsabilidade e espírito de colaboração dos educandos. Por meio delas, os alunos poderiam reconhecer suas próprias peculiaridades e preferências, favorecendo o desenvolvimento da sua personalidade; garantiriam o sentido prático ao ensino teórico por meio da aplicação dos conteúdos; exercitariam sua iniciativa e senso de responsabilidade, pois as atividades se realizariam também por meio da direção dos alunos; aprenderiam o senso de realidade, relacionando-se com a sociedade circundante e interagindo com as autoridades educacionais; promoveriam oportunidades didáticas diferenciadas para os alunos atrasados nos estudos ou desmotivados, elencando-se, assim, alguns dos saberes e fazeres discentes associados às situações festivas (NÉRICI, 1960).

Já existe, há longo tempo, nas escolas do Estado, um dia escolhido para o "culto à bandeira Nacional", outro, em que se realiza o "culto às aves", e outro para o "culto à arvore". Encerram estas festas profundo conceitos educativos, uns morais e outro religiosos, além dos conceitos econômicos e positivos. São festas simbólicas, de que usam as escolas modernas, como um dos meios soberbos de cultura moral de mental (Revista de Ensino, agosto de 1902, p.103-104).

Os trabalhos realizados pelos escolares ganharam novos significados para o cotidiano da escola; já não se realizava as tarefas somente para a apreciação e avaliação dos professores, mas existiria ainda, a possibilidade de que tais exercícios, quando realizados com perfeição nas diferentes disciplinas, pudessem ser apresentados nas 
exposições escolares de final de ano, também consideradas motivos para se festejar. Além de se constituírem como um importante elemento da emulação escolar, as exposições escolares pretendiam interessar as famílias e aos estranhos, mostrando-lhes como se trabalhava na escola. Para Vasconcelos (1925), era muito louvável o intuito da escola em "procurar demonstrar publicamente dum modo palpável o valor do seu esforço expresso nos resultados que obtém dos seus educandos" (p. 197). As exposições escolares dariam aos alunos "oportunidade de comparar seus trabalhos: os menos caprichosos tudo fariam para que, em próximas exposições, as suas produções não fizessem tão má figura...” (NÉRICI, 1960, p. 395). Dessa forma, disciplinas como o desenho e os trabalhos manuais, concebidos como formadoras do caráter e de preparação para o trabalho galgaram visibilidade nas apresentações dos trabalhos escolares. Nas aulas de trabalhos manuais se aprenderia a valorização, o respeito e o início da aprendizagem de um ofício, associado aos afazeres da casa para as meninas e as funções sociais para os meninos:

$\mathrm{Na}$ grade e n'uma sala próxima estavam expostos vários trabalhos das educandas, bordados, flores, desenhos, aquarelas, alguns dos quais de subido mérito, honrando sobremaneira as gentis artistas e suas professoras.

Antes da distribuição e depois d'um hino cantado por todas as educandas com as suas vozes cheias de frescura e de alegria, principiou o concerto intervalado por várias poesias, terminando a festa por exercícios de ginástica elementar em que tomaram parte as crianças mais pequenas.

Todos foram aplaudidos e todos o mereceram.

Em seguida à distribuição dos prêmios uma das educandas recitou primorosamente uma esplendida poesia composta expressamente pelo nosso insigne poeta Thomaz Ribeiro.

Depois d'uma pequena prática dirigida, às educandas pelo $\mathrm{Sr}$. Patriarca, abriu-se a porta do convento d'onde saiu um bando de pombinhas brancas, risonhas, contentes, abraçando os pais enternecidos (A Escola: Revista de Pedagogia e de Instrução Pública, agosto de 1890, s.p).

As discussões acerca dos trabalhos escolares desenvolvidos pelas crianças eram apresentadas como uma das formas privilegiadas de aprendizado, de acordo com os adeptos das teorias de ensino renovadas, já que propiciariam um aprendizado mais eficaz, no qual o aluno poderia praticar tudo o que estava aprendendo, e também, como situações preparatórias para os trabalhos a serem assumidos no meio social. No ensino, tornar-se-ia questão premente, a consideração do interesse dos indivíduos, mas também o interesse da sociedade a qual pertence nos trabalhos desenvolvidos pela escola. "A educação será boa se aumentar, se valorizar o trabalho e o rendimento do indivíduo 
como particular e, simultaneamente, que, com essa valorização ou rendimento, aproveite ou utilize a coletividade" (Revista Escolar Portuguesa, novembro de 1921, p. 321-322). Na opinião do educador Manuel da Mota Veiga Casal (1921), se constitui projeto das instituições de ensino preparar as crianças para a "luta da vida"; seria necessário colocá-las em contato, diariamente, com ela por meio do trabalho, "alegria, labor em comum, considerando a agulha, a vassoura, a terra argilosa, o martelo, a flor, a ave, o canto, os jogos e a dança como partes integrantes da escola" (idem, ibidem).

A pouca importância atribuída aos trabalhos manuais pelas escolas primárias portuguesas foi considerada, em certo momento histórico, como uma das causas da crise da instrução popular. A escola deveria educar para o trabalho e pelo trabalho, considerando o que há algum tempo se preconizava sobre uma escola que não somente ensinasse a dizer, mas também a fazer. Em suas argumentações sobre a orientação do ensino perante a crise nacional, Albano Ramalho (1921) indicava que se teria chegado a um período histórico em que ainda mais se imporia a necessidade de "levarmos a criança a adquirir grande desenvolvimento e habilidade manual, apreciáveis qualidades de destreza, de agilidade, de trabalho" (Revista Escolar Portuguesa, janeiro de 1921, p. 06), sendo, para isso, preciso a destruição do preconceito "tão próprio dos latinos - que o trabalho manual, se não avilta, como noutros tempos, honra menos do que a função pública, embora esta seja mal remunerada" (idem, ibidem). Como forma de dar sentido aos trabalhos realizados pelos alunos nas escolas e aproximá-los dos que iriam ser realizados nas comunidades locais, as Caixas Escolares indicaram como uma das fontes constituintes do seu capital a venda dos objetos produzidos pelas crianças:

Do capital da Caixa

(...)

$4^{\circ}$ Produto dum bazar por ocasião da exposição escolar dos trabalhos dos alunos, que deve realizar-se no fim de cada ano letivo na escola ou noutro edifício mais apropriado (Revista Escolar, fevereiro de 1930, p 113-114).

Nas propostas educativas renovadas, os trabalhos realizados pelos alunos eram representados como "sina da precedência da inteligência prática sobre a inteligência teórica" (Ò, 2003), bem como o progresso da moral. Propuseram (LIMA, 1914; DEWEY, 1936; FERRIÈRE, 1934, entre outros representantes da Escola Nova), não somente, a inclusão da disciplina trabalhos manuais (diferentes para meninos e meninas) nos planos curriculares de ensino primário e secundário, como também a confirmação da sua centralidade em termos socializadores. Os trabalhos manuais referenciaram o exercício 
corporal e foi considerado mais valia para o desenvolvimento intelectual e psíquico da criança. Adaptados ao desenvolvimento intelectual das crianças, essas atividades incrementariam as faculdades de observação, comparação e imaginação, estimulariam o espírito da iniciativa e da cooperação, favorecendo qualidades como a exatidão e o rigor (idem, p. 144).

Levar em conta o impulso vital da criança significava partir das suas atividades manuais e construtivas, cabendo ao educador moderno "tirar o maior partido da espontaneidade associada nos trabalhos manuais para favorecer a emergência dos valores espirituais na alma infantil” (Ò, 2003, p. 144). Essa atividade permitiria, ainda, mostrar a adaptação social; a escola forneceria ocasião para as crianças trabalharem com o corpo e com as mãos, a ensaiar alguns trabalhos que futuramente poderia realizar na sociedade e o trabalho ficaria justificado porque correspondia a uma necessidade interna dos sujeitos (idem, p. 146). Além disso, de acordo com discursos veiculados no período, a verdadeira democracia consistiria "em tornar a instrução popular compatível com o trabalho manual, que dignifica e não coloca em plano inferior ao do trabalho intelectual" (Revista de Ensino, março de 1906, p. 799-800).

$\mathrm{Na}$ passada segunda-feira tivemos ensejo de assistir a uma linda e proveitosa festa na escola da Ameixoeira. A convite de sua ilustre diretora, a nossa colega Exma. Sra. D. Antónia Lopes Amaro, ali fomos a abertura da exposição dos trabalhos escolares, que enchiam por completo a sala da aula. A exposição foi deveras admirável tanto pela quantidade quanto pela qualidade dos trabalhos, sendo de notar que todos eles eram, de fato, executados pelas alunas. A secção destinada aos trabalhos em cartolina e arame era interessante, revelando o cuidado que a nossa colega pôs na orientação que lhes imprimiu. A secção de lavores era sobremaneira notável, demonstrando muita competência e dedicação e as alunas devem ter ficado muito contentes por terem verificado o apreço em que eram tidos os seus trabalhinhos (A Escola Primária, julho de 1929, p. 368).

Trabalhando na escola se aprenderia a trabalhar na sociedade. Na escola, as diferenças entre os programas de disciplinas, como trabalhos manuais e ginástica para as meninas e meninos, apesar do currículo ser o mesmo para ambos, indicaram, além da preocupação com a educação integral (físico, intelectual e moral), questões de gênero que não podem ser desconsideradas. Para os meninos, eram previstas atividades de marcenaria, olaria, modelagem, trabalhos com vime, madeira ou ferro; para as meninas, bordados, costuras, pinturas em tecido ou a óleo.

Entretanto, existiu um problema nas preparações e exposições dos trabalhos escolares, segundo Faria de Vasconcelos (1925), pois só exporiam os melhores 
trabalhos. Muitas vezes, os trabalhos eram feitos especialmente para a exposição, não indicando assim, o que realmente se fez no desenvolvimento do ano escolar; outros trabalhos dos escolares eram ainda produzidos em casa, o que prejudicaria o 'controle e o auxílio do mestre'. Para estes casos, o autor propõe como soluções: a consideração de todos os trabalhos na exposição escolar, tanto os bons quanto os maus; o aproveitamento da exposição escolar como momento fecundo para os professores incitarem faculdades como iniciativa, responsabilidade e organização dos alunos quanto a escolha do local, arranjo material, destruição dos trabalhos etc: "E, assim, uma vez mais a atividade dos alunos será o eixo, a mola essencial do mecanismo e funcionamento desta instituição escolar" (Revista Escolar Portuguesa, maio de 1925, p. 199).

$\mathrm{Na}$ esteira das críticas elaboradas por Vasconcelos (1930), em dezembro de 1930, ficaram registradas nas páginas da Revista Escolar Portuguesa censuras bastante duras à realização das exposições escolares nas instituições portuguesas. Para o educador Vidal Oudinot (1930), as exposições escolares eram sempre, nas escolas "do meu país, um embuste grosseiro que o nosso espírito aceita, por comodismo, por negligência e ... por falta de moral profissional" (p. 567), já que era de conhecimento de todos que a maioria dos trabalhos expostos não eram executados pelos alunos, que se limitavam a fazer "cópias ou imitações absurdas das estampas ou do natural, rabiscos, logo inteiramente modificados pela borracha e pelo lápis do professor" (p. 567). Neste sentido, e concordando que as exposições foram agentes admiráveis para despertar a atividade, a emulação e, por conseqüência, o desejo de atingir um fim mais elevado, Oudinot (1930) propunha atingir esses fins de "outra forma mais honesta, mais visível, que não o da falsidade que deprime o sentimento, enfraquece a atividade e insensibiliza o estímulo" (Revista Escolar Portuguesa, dezembro de 1930, p. 567-568). Apesar das críticas presentes em diferentes momentos e direcionadas para as distintas atividades festivas, era ainda nesses momentos que os alunos encenavam para a sociedade "o espetáculo da cultura, das letras, da ordem, das lições morais e cívicas" (SoUZA, 1998, p. 254). Cada um dos atos da festa era uma prática simbólica portadora de significados sociais e culturais partilhados.

Aliadas às disciplinas curriculares obrigatórias, as festas escolares seriam capazes de potencializar o aprendizado de conteúdos tidos como demasiados abstratos para as crianças, como por exemplo, o civismo, pois naquelas ocasiões os alunos teriam a oportunidade de vivenciá-los e aprendê-los de forma intensa. As orientações presentes 
sugeriam aos professores que não se limitassem somente a explanar os conteúdos, pois "perderá metade de seu esforço e de seu tempo: - materialize, objetive seus pensamentos" (TOLEDO, 1932, p. 83-84); assim, os educandos conseguiriam acompanhar melhor os ensinamentos. A literatura didática, os livros de classe, os livros de leitura, "calcados sobre as tendências afetivas e gostos imaginativos da criança, podem mover o assunto das lições na esfera ampla dos ideais enunciados" (idem, ibidem). Nos momentos de leitura e recitação dos programas festivos, os alunos teriam suas inclinações e interesses despertados, formariam a sua moralidade, concretizado o entendimento da lição apresentada:

No entrecho gracioso e dramatizado de um conto, os sentimentos do herói da peça, se vibrarem em uníssono com as inclinações e interesses do pequenino leitor, fortalecerão as cordas de sua sentimentalidade, fixando-as na altura desejada. (...) Faça o professor que o pequenino, levemente auxiliado, enuncie a moralidade encerrada no conto que leu. Essa é a prova de que a lição foi entendida e assimilada (TOLEDO, 1932, p. 83-84).

As lições organizadas nas matérias do currículo oficial poderiam contar com mais um dispositivo para o seu ensino e consolidação dos seus conceitos por meio das festas escolares, distanciando-se das suas ciências de referência e tornando-se criações originais das escolas (CHERVEL, 1990). Ao mesmo tempo em que elas contribuíram para a confirmação dos saberes aprendidos, pelo uso de uma metodologia diferenciada, também foram contempladas nos programas de algumas disciplinas, entendidas aqui como "modos de transmissão cultural que se dirigem aos alunos" (idem). Neste caso, as funções dos professores nas solenidades escolares não se resumiriam à projeção e realização das festas, mas à integração dos saberes curriculares associados a tais eventos, ensinando-os e garantindo seu aprendizado sob o pretexto da festa e a adesão dos alunos. Os preparativos para as festas aconteciam durante todo o ano letivo nas aulas, por meio dos ensinamentos de disciplinas consideradas obrigatórias do currículo, e terminavam com as apresentações públicas que coroavam o efetivo aprendizado de tudo o que era ensinado. Muitas foram as matérias que, ao serem aprendidas em sala pelos alunos, concorriam para o preparo individual e coletivo nas situações de comemorações escolares. Desse modo, é possível dizer que os saberes associados às festas escolares extrapolaram a organização das mesmas, e estiveram presentes e se relacionaram desde as discussões acerca dos melhores métodos de ensino, até os conteúdos disciplinares que se potencializariam nestas ocasiões. 
O programa do curso preliminar estabelecido pela reforma da instrução pública paulista no ano de 1892, estabeleceu um conjunto de conteúdos que, segundo Souza (1998), puderam ser agrupados em matérias de três subgrupos. O primeiro, das matérias elementares, compreendendo as competências básicas de leitura, escrita e cálculo; no segundo, aquelas de natureza propriamente científica: as noções básicas ${ }^{54}$ de ciências físicas, químicas e naturais e, por fim, as de formação moral, cívica e instrumental, presente nas matérias como geografia e história, educação cívica, moral, música, ginástica e exercícios militares, desenho e trabalhos manuais (SoUZA, 1998). A participação dos alunos em aulas referentes a essas disciplinas seguiriam um gradativo detalhamento no preparo dos alunos às festas, seja no que diz respeito a sua organização (data, programas, divulgação), ou até mesmo aos conteúdos a serem apresentados pelos alunos em tais oportunidades (declamações, hinos, teatros):

a) Durante o período preparatório destas festas, as crianças aprendem literatura, história e geografia (matérias relacionadas com as poesias, monólogos, diálogos, etc., que fazem parte do programa); aprendem música (pelo menos educam o ouvido); aprendem a pronunciar com exatidão, e até podem adquirir maneiras menos grosseiras'(Nota 1. Vide Mario Gonçalves Viana, Festas Escolares Considerações Gerais, in: Escola Portuguesa, Lisboa, 28 de Dezembro de 1944) (VIANA, 1946, 1960, p. 366-367).

Nas aulas de canto coral, música e teatro, os alunos aprendiam saberes a ser apresentados nas manifestações artísticas das comemorações; já em aulas como história e geografia, os motivos das datas históricas selecionadas, a constituição do território nacional e os símbolos que representavam as unidades das nações (especialmente, representadas nas festas da natureza), os heróis, os acontecimentos históricos que, solenizados, compuseram a memória da nação; em língua portuguesa ou português, podiam produzir os textos das homenagens, discursos e poemas que seriam declamados. No ensino cívico e moral, a apresentação dos valores e comportamentos pelos alunos do ideal de cidadão a ser perseguido por toda a população; a ginástica e os exercícios militares eram aulas que facilitariam o desempenho nos desfiles, jogos e torneios que poderiam constar dos programas das festas, e os desenhos e trabalhos Manuais seriam reconhecidos nas exposições de final de ano. Nas matérias elencadas, as comemorações escolares eram apresentadas como possibilidade metodológica diferenciada para a garantia de um aprendizado que poderia se fazer sem elas, ou seja, as festas constituíam-

\footnotetext{
${ }^{54}$ O princípio básico de seleção dos conteúdos correspondeu a finalidade instrumental do ensino primário, à adequação psicológica da criança e à observação do meio (SOUZA, 1998).
} 
se um suporte, um algo a mais, ou mais uma metodologia a ser aplicada no ensino de conteúdos que delas não prescindiam; diferente do que aconteceu com os conteúdos de ensino cívico e moral, nos quais a aprendizagem dos símbolos e valores associados às ideias de pátria, cidadão, nação e território somente poderiam se realizar com o seu auxílio.

No caso do civismo, conteúdo e valor considerado imprescindível para a formação do cidadão republicano, e ainda como forma de garantir a coesão social, foram considerados meios auxiliares desta aprendizagem, todos os trabalhos escolares capazes de colocar em prática os conceitos abstratos em atividades cívicas da criança, tais como o escotismo, a celebração das festas patrióticas, as leituras e narrações de exemplos de patriotismo, o estudo dos livros de texto (somente nos últimos graus da escola), as excursões escolares e visitas a lugares onde existem instituições sociais e políticas (câmara municipal, agências de correio, instituições beneficentes etc.), assim como as dramatizações cívicas, o rádio, o cinematógrafo e alguns jogos escolares (AgUAYO, 1935).

Comemoração da Constituição Brasileira - Constou essa festa de um préstito formado de alunos e professores do Grupo que percorreram as principais ruas daquela cidade, sendo saudados por esta ocasião as principais autoridades do lugar. Em seguida, o préstito dirigiu-se para o Grupo, onde após um pequeno intervalo, reuniram-se todos os alunos no salão de honra. Ai foi desenvolvido um programa musicalliterário, que agradou muito as pessoas presentes e dissertaram sobre a data 14 de fevereiro o diretor Joaquim de Sant'Ana, professor Julio Marcondes do Amaral e Marcolino Silva (A Eschola Pública, 15 de março de 1897, p.125).

O civismo é conceituado no repertório em questão como os ideais nacionais, aqueles que constituem a finalidade particular da escola brasileira e portuguesa, isto é, a cuidadosa conservação da língua, a cultura das tradições, o conhecimento da geografia pátria e da história dos povos. O seu ensino, por meio das homenagens às autoridades, hinos e literatura patriótica e passeatas pelas localidades, deveria ser trabalhado de forma conjunta com as informações necessariamente breves e concretas sobre a estrutura e funções da sociedade e do governo: "tais livros devem motivar e provocar as atividades cívicas das crianças por meio de problemas e projetos, visitas à instituições locais, excursões e outras formas de trabalho escolar" (AGUAYO, 1935, p.264). Com relação à eficiência dos métodos pedagógicos solicitados para o ensino do civismo, os autores dos manuais pedagógicos assinalaram não ser eficiente somente o uso dos livros 
didáticos ou a exposição dos professores, mas seria essencial que este ensino se materializasse e objetivasse seus pensamentos por meio de elementos tais como:

Os arranjos escolares, o escotismo, as excursões, a observação da natureza, os hinos, as danças, os jogos, o desenho, o trabalho manual, comentários a acontecimentos palpitantes da época, são mil modos de objetivação interessante e atraente a tornarem efetivas as emoções que as palavras só transitoriamente e dificilmente evocam na mente verde da infância. Ainda que a influência pessoal do mestre, no correr de todo o curso escolar, tenha muito maior valor que "os auxílios mecânicos das livrarias, dos laboratórios e das oficinas, não deixemos de ter em alta conta a valia destes materiais, que fazem o aprendizado muito mais eficiente" (TOLEDO, 1932, p. 83-84).

Os saberes a serem aprendidos pelos alunos por meio das festas poderiam vir em histórias com lições de moral, civismo e altruísmo, especialmente nas disciplinas de história e geografia que prestavam sobremaneira à formação do caráter. No curso primário, a história ensinada compreendia narrações sobre o descobrimento do Brasil e os principais acontecimentos históricos do país, tais como a Independência, a República e a biografia de personalidades ilustres: "Uma história factual e celebrativa cuja finalidade última era cultivar o amor à pátria" (Souza, 1998, p. 179). Ao lado das comemorações caberia a seleção de pequenas histórias que pudessem ensinar pela emoção, como o exemplo noticiado na Revista de Ensino, de março de 1916, que narrou a coragem de um garoto que, em meio a um naufrágio, pulou ao mar e salvou a bandeira nacional; este foi considerado um exemplo de amor à Pátria, que deveria ser seguido por todos os outros alunos presentes. Na ocasião da Festa da Bandeira do referido ano, este garoto recebeu uma medalha de honra e muitas ovações.

Em determinadas festas eram constitutivos do programa a apresentação de ginástica, exercícios militares e jogos escolares pelos alunos. A educação física era destacada pela sua influência moralizadora e higiênica (SoUZA, 1998), cujas justificativas para a inclusão destas práticas no currículo escolar foram engendradas no decorrer do século XIX, especialmente no discurso médico-higienista ${ }^{55}$, que pretendeu organizar a educação escolar como um modelo "moderno ou iluminista" de formação de homens e mulheres (GONDRA, 2003). A racionalidade médica transformou o corpo do

\footnotetext{
${ }^{55}$ Ao longo do século XIX, a agenda médica reservou um lugar especial para os problemas de ordem social, como a formação sistematizada das novas gerações, realizadas por meio da educação escolar. Neste sentido, destacaram-se ações como a dos médicos Abílio Cesar Borges e Joaquim José Menezes Vieira, ambos donos de escolas particulares no Brasil imperial e, no início do século XX, figuras de médicos como Caetano de Campos, Afrânio Peixoto e Miguel Couto, que se dedicaram à causa educacional, na direção da Escola Normal, no parlamento e na área editorial (GONDRA, 2003). A área da higiene forneceria um modelo de organização útil da instituição escolar baseado na razão médica.
} 
escolar e as práticas escolares em objetos de seus estudos. Educar deveria significar a possibilidade de constituição de um indivíduo forte, robusto, puro e sábio: "O ordenamento proposto pela doutrina médico-higiênica queria pôr fim aos semblantes plácidos, descarnados, contristados e sem expressão" (GONDRA, 2003, p. 535), que se podia ver na feição dos escolares. A educação não "seria eficaz e plena caso não abrigasse a dimensão corporal em sintonia com os cânones da higiene, de modo a se conquistar um corpo forte e saudável” (idem, p. 537), promovendo, dessa forma, a crença da irredutibilidade ao físico, ao moral ou ao intelectual. A educação física era apresentada como uma prática essencial para o bom desenvolvimento do intelecto e da moral das crianças, justificada por argumentos que passavam desde a questão da hereditariedade, o determinismo geográfico até o evolucionismo cultural.

Tornar os corpos ágeis, fortes, robustos, vigorosos. Desenvolver a coragem, o patriotismo. Todo um investimento no corpo dos indivíduos que os engalfinhava nos ideais de moralização e ordenação social (SOUZA, 1998, p. 179).

A vida higiênica infantil seria completa por meio de uma vigilância constante ${ }^{56}$ e atividades de educação física, desenho e trabalhos manuais. "Na falta de espaço próprio para a realização de exercícios ginásticos, professores e alunos passaram a utilizar espaços públicos: jardins, praias e mesmo clubes esportivos (Botafogo, Flamengo, América, Helênico, Light Garage) para treinamentos físicos regulares" (NuNES, 2003). As provas de exercícios físicos de conjunto que, em 1924, reuniu dois mil estudantes e em 1925, quatro mil crianças,

obtiveram os aplausos da opinião pública em geral e, particularmente, da Liga de Esportes do Exército. Esses acontecimentos foram filmados e exibidos em outras capitais do país. Pela grandeza da raça, que retratou esses eventos, provocou a vinda de professores mineiros e pernambucanos para o Distrito Federal, sob o patrocínio dos governos estaduais, com o intuito de receber orientação da comissão de especialistas que sistematizou a educação física praticada em algumas escolas da Capital Federal (NUNES, 2003, p. 386).

\footnotetext{
${ }^{56}$ No Rio de Janeiro, nas décadas de 10, 20 e 30 do século XX, instituíram-se, nas escolas, os pelotões de saúde, compostos por alunos mais comportados e/ou aplicados de algumas turmas. Caberia a este grupo de alunos manter a vigilância sobre o estado de limpeza do corpo, da roupa e dos modos dos seus colegas. Para cada aluno e para cada dia da semana o pelotão determinava tarefas higiênicas a serem cumpridas. Eles eram identificados, na escola, pela utilização de uma faixa com a cruz vermelha presa ao braço (NUNES, 2003).
} 


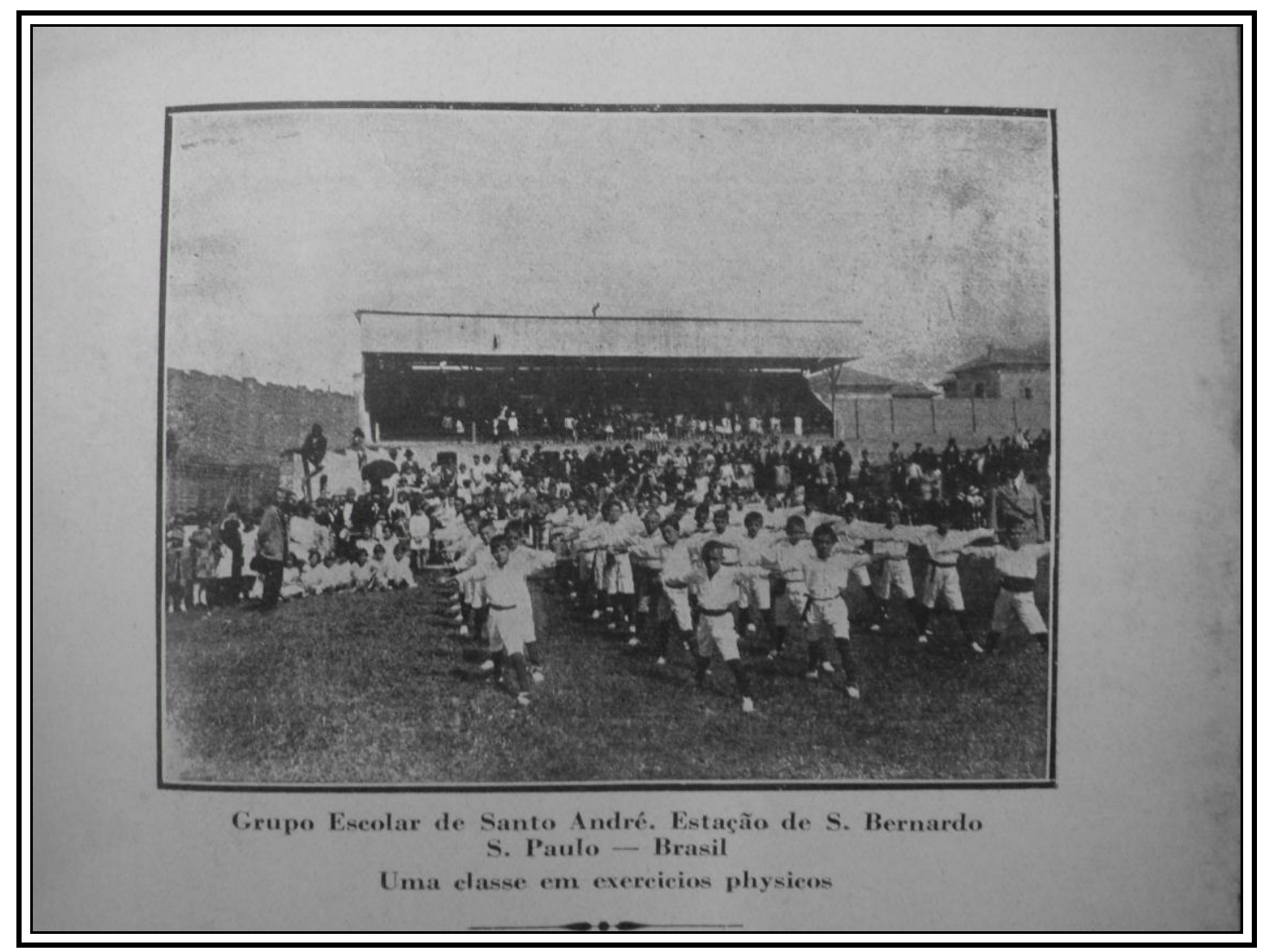

"A Cultura Física nas escolas". Anuários do Ensino do Estado de S. Paulo, 1926, p. 23.

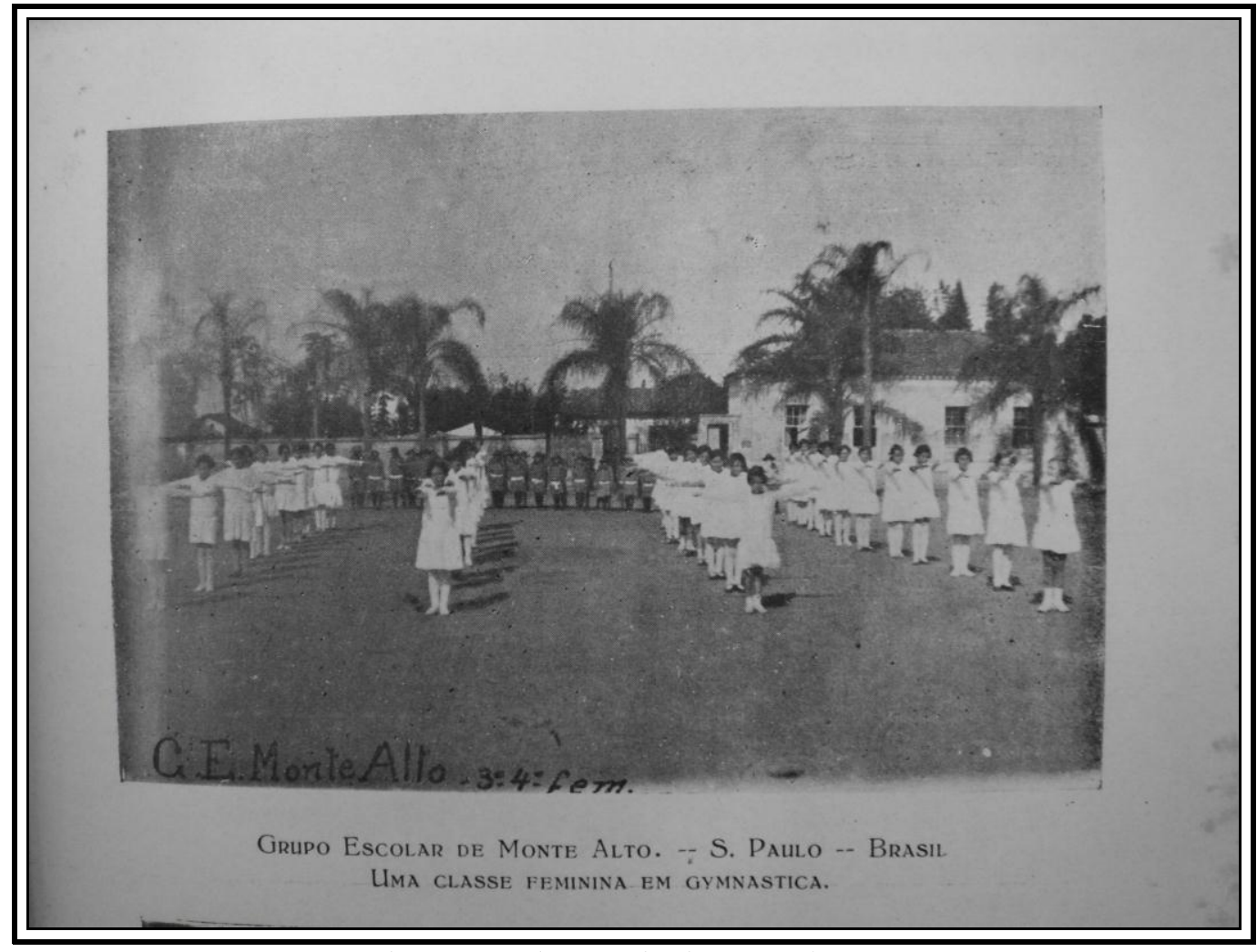

Anuários do Ensino do Estado de S. Paulo, 1926, p. 121. 


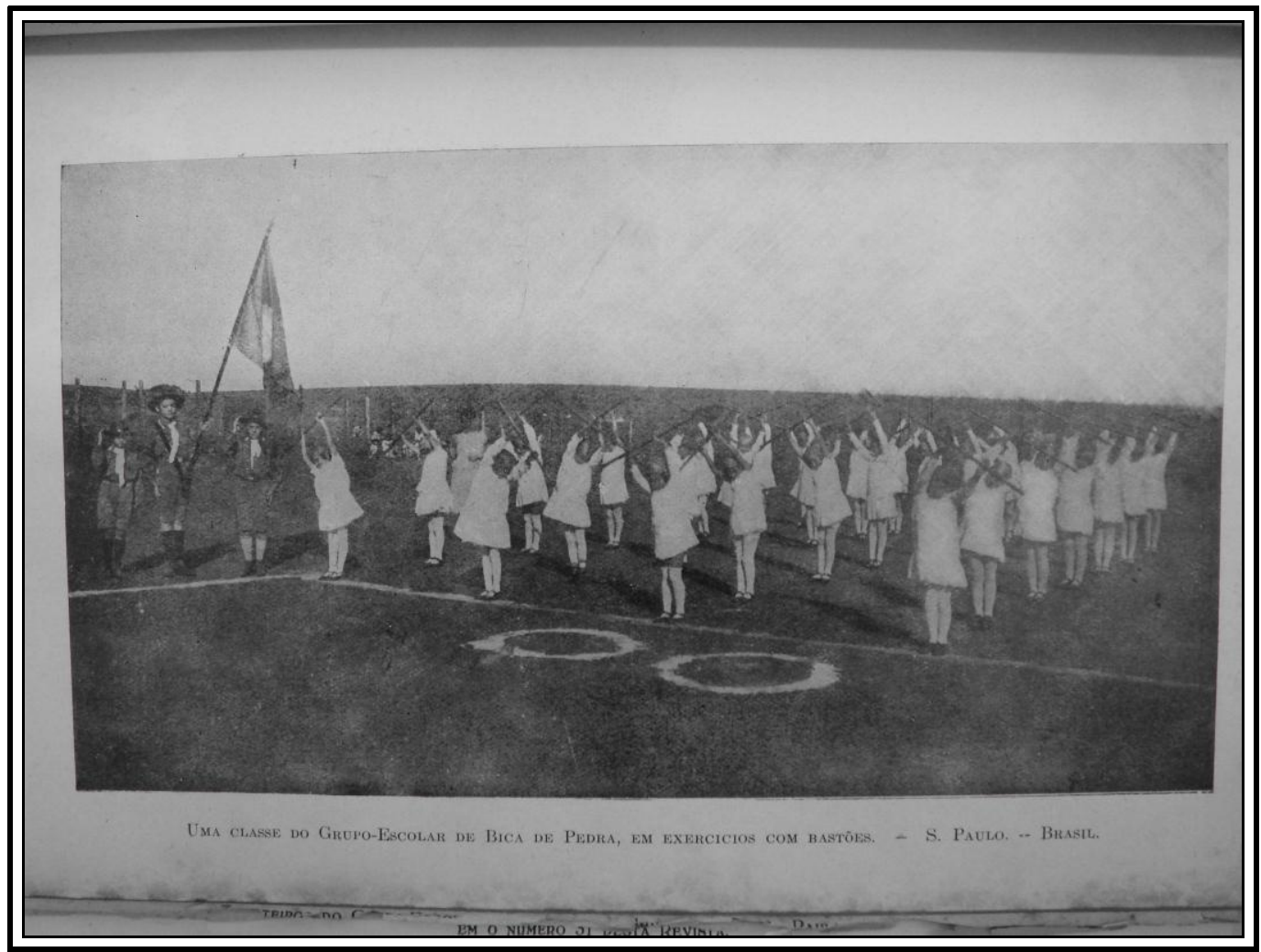

Anuários do Ensino do Estado de S. Paulo, 1926, p. 481.

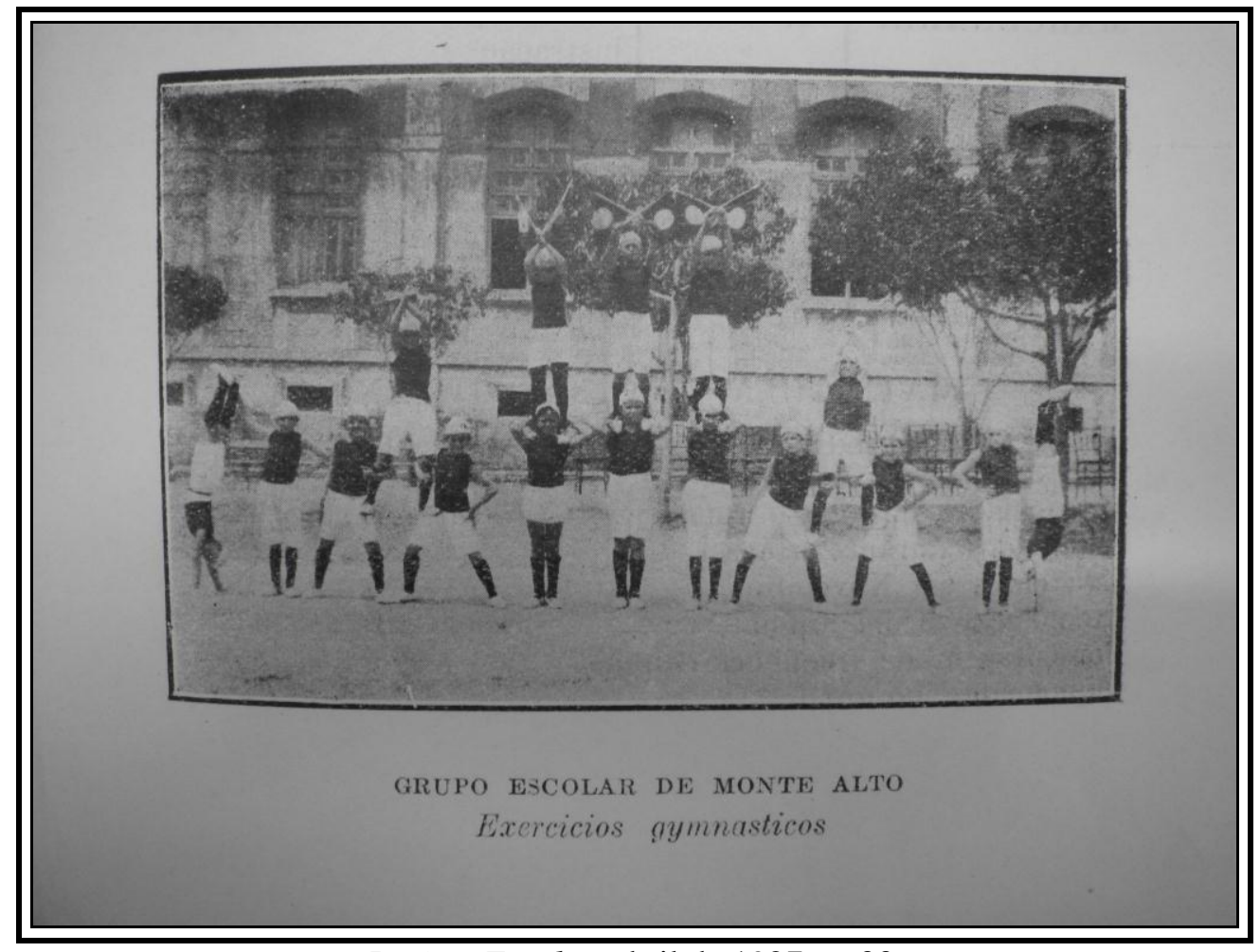

Revista Escolar, abril de 1927, p. 33. 


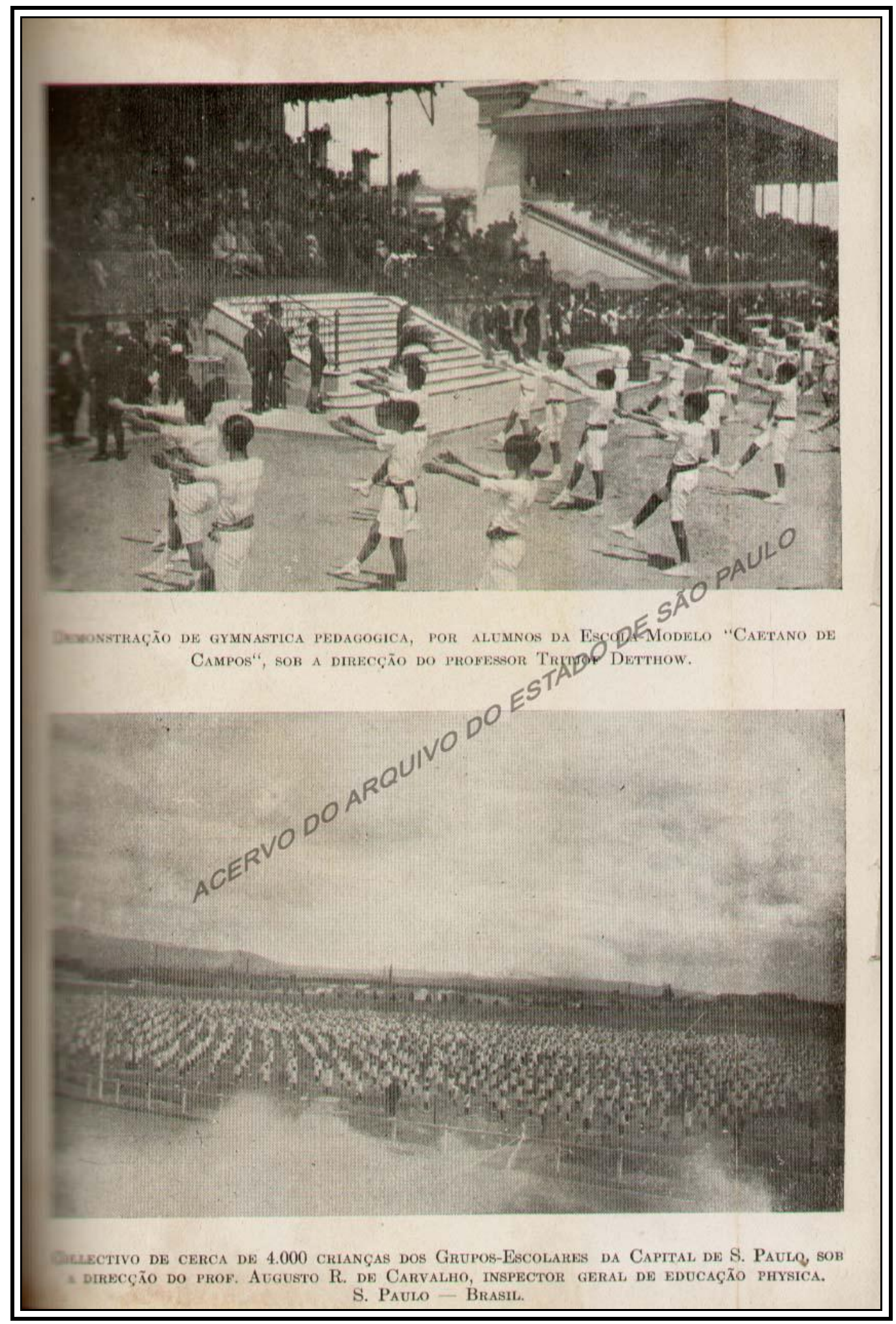

Revista Escolar, julho, de 1927, p. 17. 
Relacionada às práticas da educação física escolar, dos exercícios de ginástica e das apresentações competitivas, esteve a possibilidade de desenvolvimento de um tipo de educação especial não só entre os alunos, mas também para a população em geral: a educação estética, presente nos conteúdos escolares, na organização do espaço urbano e escolar e na rotinização de acontecimentos promotores da emoção estética, como as festas nas escolas e as dos escolares nas cidades. O projeto republicano de formação cívica não se faria, somente, com a criação de escolas, mas também com uma educação estética que envolvesse "habilidades manuais, a educação das mulheres para o lar, o contato com a literatura brasileira, os cantos, a dança, presentes no cotidiano das salas de aula, nas festas escolares, nas festas das cidades" (VEIGA, 2003, p. 407). As festas cívicas e escolares seriam concebidas como o auge de "uma comunhão nacional e da homogeneidade cultural, em que todos são um só canto e uma só imagem” (idem, p. 406). As propostas relacionadas à educação estética também fizeram parte dos debates relativos à escola nova nas décadas de 20 e 30 do século XX, promovendo as relações entre a razão e os sentidos.

A educação estética, tal como compreendida na modernidade, é parte do contexto de valorização das culturas nacionais e, ao mesmo tempo, da valorização do sujeito autônomo, individualizado e racionalizado, que por isso é capaz de se identificar com os princípios e valores universalizados, necessários à harmonia social (VEIGA, 2003, p. 409).

Destacou-se no âmbito das discussões acerca das potencialidades das festas a promoção da educação estética das crianças, apesar de não constar como disciplina dos currículos oficiais, era uma parte importante do ensino, cuja responsabilidade pelo seu desenvolvimento recaia mais uma vez nas atribuições dos professores. A educação estética era entendida como aquela capaz de formar o aluno para a fruição das mais variadas formas de expressões artísticas, tais como o canto, a dança, a música, a literatura, o teatro e os trabalhos manuais, bem como às formas de educar para produzir uma então denominada emoção estética. As festas formuladas pelas escolas e realizadas em público contribuíam para esta formação, ao permitirem consolidar, nos espaços públicos e urbanos, novos valores e atitudes, indicando às cidades, não somente como espaços de deslocamento ou de trabalho, mas como local de culto à pátria, de comunhão cívica, de recepção estética, do cultivo ao belo, da harmonia e da ordem. A formação estética dos alunos aconteceria no momento de estudo dos poemas a serem recitados, nas aulas de canto e música, na ornamentação das escolas para as festas, na participação 
das mesmas e especialmente, nas expressões de cultura física como ginástica, marcha ritmada e jogos escolares, tudo realizado com a maior disciplina e uniformidade.

As festas, exposições pedagógicas, eram organizadas, preparadas e apresentadas para despertar na população uma emoção diferente, que perfilassem a harmonia, a ordem, o belo (VEIGA, 2003, p.419).

A pedagogia dos sentidos (SOUZA, 1998), decorrente da ampla divulgação do método intuitivo como sinônimo de modernidade educacional nas décadas finais do século XIX e iniciais do XX, pressupunha tornar os alunos ativos por meio de tarefas variadas como o desenho, a música, o teatro e a dança e, também, por meio das festas, propiciando a educação estética dos alunos e de toda a população. Retomando o conceito de habitus era desejável que por meio dessas situações os alunos e a população assistente conseguissem fomentar uma série de disposições e esquemas de pensamentos orientadores de práticas de apreço e de desvelo desses valores sociais. Ao atuar de maneira ativa e criativa sobre esses elementos alimentou-se, entre os idealizadores da república a esperança de formação de uma sociedade diferente composta de cidadãos que valorizassem e protegessem a sua pátria.

A elaboração do projeto de festa educativa perpassou conceitos centrais da pedagogia da Escola Nova como o de interesse, atividade, relação sociedade e escola até os saberes curriculares dos programas oficiais, disciplinadores e moralizadores das mentes e dos corpos possibilitados pelos eventos festivos. Ao realizarem as festas, as crianças puderam ter reconhecidas as suas identidades como alunos pertencentes a uma determinada instituição de ensino, em um contexto social e histórico delimitado. Ao definir um conjunto de esquemas de percepção do mundo e da escola, de pensamento e de ações festivas, as crianças puderam ter reorientadas as suas práticas e representações acerca do ideal de escola, escolarização e de alunos. Identidades discente e docente que se associaram ainda às funções sociais das escolas e as relações que as mesmas estabeleceram com as comunidades as quais pertenciam. Elas permitiram, não somente, o aprendizado das engrenagens e de suas funções dos festejos, mas, ao associarem-se a outros aprendizados escolares, como o civismo, a higiene e a educação estética, potencializaram seus ensinamentos na esfera social e na formulação de uma categoria escolar. Os saberes e fazeres festivos extrapolaram as próprias festas e mostraram-se imbricados em um jogo de estratégias e situações relacionais cujas análises apresentadas neste capítulo indicam apenas uma das possibilidades de pesquisa nesse percurso. 


\title{
Capítulo 3: De como montar a "máquina" festiva: os saberes e os fazeres educacionais associados às festas
}

\begin{abstract}
Inaugura-se no dia $1^{o}$ de junho, ao meio dia, a exposição pedagógica escolar, no palácio de Cristal do Porto (...) n'ela se representarão os que ensinam e os que aprendem, como verdadeiros gladiadores nas lutas da civilização e do progresso. Alegrem-se, portanto, os que amam a instrução, e corem de pejo os que ainda não esqueceram as épocas (...) do obscurantismo (A escola: Revista de Pedagogia e de Instrução Pública, maio de 1890, s.n).
\end{abstract}

A constituição de um sistema público, estatal, laico e democrático de ensino, como propunha os reformadores da instrução em Portugal e no Brasil na viragem do século XIX para o XX, não se faria sem uma alteração significativa das representações sobre os saberes e os fazeres dos professores em todos os níveis, especialmente, para o nosso caso, do ensino público primário. Se em períodos anteriores, os professores contavam com relativa autonomia para a escolha dos locais das aulas, dos horários de funcionamento das escolas e dos dias da semana a serem utilizados, das disciplinas ${ }^{57}$ ministradas e das atividades a serem realizadas, constituindo redes ainda pouco organizadas de ensino, a partir das reformas empreendidas para a constituição do sistema público e estatal de ensino, suas atribuições modificaram-se definitivamente. Os anos finais do século XIX, especialmente no caso do Brasil, e iniciais do século XX, em Portugal, foram marcados por várias reformas educacionais ${ }^{58}$ cujo intuito foi o de indicar a organização ideal do espaço, do tempo, dos currículos, dos métodos e das atividades escolares e, dentre essas, das festas escolares.

O projeto educacional de implantação dos grupos escolares, considerado o modelo moderno de estrutura escolar, alterou significativamente o cenário educacional

\footnotetext{
57 A disciplina escolar como um conjunto de regras e de dispositivos utilizados para o governo dos espíritos e para a formação do caráter (Ó, 2003) foi utilizada nesta tese como sinônimos das matérias curriculares e dos comportamentos desejados para os alunos.

58 O ensino proposto na reforma do ensino de 1911, em Portugal, deveria garantir o desenvolvimento orgânico e fisiológico e o desenvolvimento intelectual e moral da criança, por meio de um ensino graduado, concêntrico e metódico. A reforma reorganizou o ensino infantil (que era facultativo) e estruturou o ensino primário em três graus: elementar (obrigatório dos 7 aos 10 anos), complementar (dos 10 aos 12 anos) e superior (dos 12 aos 15 anos). "O mesmo diploma reorganizou ainda as escolas normais primárias e descentralizou a gestão escolar com a atribuição de amplos poderes aos municípios nesta matéria, como já tinha acontecido com a reforma de 1878" (CATROGA, 2000, p. 257).
} 
nos dois países, as práticas docentes e, em última análise, as identidades profissionais dos educadores. A professora Hermengarda, protagonista do livro $O$ calvário de uma professora (1927), dá indícios, em seu desabafo, de como os professores sentiram essas modificações:

\begin{abstract}
Não temos senão pedir um pouco de atenção para a modesta educadora paulista, tão duramente tratada. É ela força máxima que impulsiona o complicado maquinismo da instrução pública. Mas, tão sobrecarregada de deveres, tão premiada por feitores. Muitas vezes brutais, já está ela perdendo o ânimo para o trabalho racional. Transformada em máquina, trabalha como máquina, e esse trabalho é contraprudente. Libertai-a das normas rígidas de programas forçados e extensos, não de acordo com as necessidades regionais. Deixai-a agir mais livremente. Seja ela menos escrava; tenha um pouco mais de autonomia em sua classe ou escola, e vereis o seu interesse pelo ensino. Tenha livre direito de debates, possa fazer demonstrações de sua experiência e será surpreendente o seu trabalho (...) é muito comum, uma professora pública, escrava de horário severo, que perderá o ponto pelo atraso de minutos (DORA LICE, 1927, p. 3-4, p. 192).
\end{abstract}

A partir das reformas empreendidas pelos governantes brasileiros e portugueses para a constituição do aparato educacional dos estados nacionais, os professores passaram a contar com um novo local de trabalho, construído para este fim específico, com normas e regras diferenciadas e uma organização temporal que se desejava própria e autônoma. As festas, antes organizadas em espaços públicos para toda a população, transitaram para o âmbito escolar, e este movimento fez com que as mesmas se transformassem em uma das práticas de aprendizado e de ensino da escola, ou seja, que elas tivessem reforçadas as suas características pedagógicas. Se antes, Hermengarda, não precisava preocupar-se com ensaios para a apresentação dos alunos em cerimônias públicas, com a seleção de datas e elaboração de programas festivos a partir das reformas e reestruturação do ensino, não só esses ensaios passaram a constituir parte das novas demandas do trabalho docente, organizada em um espaço e tempo determinado, como se tornou possibilidade de publicização dos trabalhos escolares e, por meio deles, da competência dos professores. Nos eventos festivos, a cultura específica da escola (Julia, 2001; ChERvel, 1990; ViÑaO Frago, 1996; AZANHA, 1990-1991) pode então, ser percebida na cultura festiva, definida em seus elementos constitutivos como a configuração de datas comemorativas incorporadas no calendário escolar; na organização dos saberes e fazeres docentes e discentes associados à preparação e ao desenvolvimento das festas; nos conteúdos a serem ensinados por 
meio das festas; nas normas específicas para a sua realização, bem como nos valores escolares e sociais associados a esses eventos.

O objetivo deste capítulo é discutir, a partir das fontes selecionadas para o estudo, as representações acerca dos saberes e das práticas docentes associados a preparação das atividades festivas: o que os professores precisariam saber para organizar um evento festivo de sucesso? Quais foram os saberes escolares associados à festa? Qual era a responsabilidade dos professores nestes eventos? Qual imagem de professor, de escola e de escolarização os professores deveriam apresentar e confirmar por meio das festas? Como transformar as festas em atividades educativas?; e por fim, quais os sentidos atribuídos a essa nova demanda escolar?

\section{1 - Os saberes e fazeres dos professores associados às comemorações escolares: nos bastidores das festas}

Organizar as festas escolares configurou-se uma das novas atribuições dos educadores nas últimas décadas do século XIX e nas primeiras décadas do século XX, constituindo-se como um elemento importante para a divulgação de um modelo ainda pouco conhecido de ensino e de escola. Às atribuições legalmente determinadas para o trabalho dos professores ${ }^{59}$, transformadas de tempos em tempos, surgiu mais uma, que era a preparação de eventos comemorativos para diferentes fins: celebração de uma data política (Proclamação da República; Independência do país; Dia da Bandeira); de sentimentos (como a caridade nas semanas da bondade, especialmente no caso português); de homenagens (aos políticos, aos reformadores, aos grandes pedagogos); de aniversários ou inaugurações de instituições escolares; de encerramento do ano letivo e formaturas das turmas, ou ainda, as festas que celebravam as riquezas de um país traduzidas na sua natureza (festa das árvores ou das aves).

Muitas foram as festas realizadas, e várias as solicitações feitas aos professores para que se envolvessem nas tarefas relacionadas a elas. O ideal do ofício do mestre ultrapassava o conhecimento dos conteúdos e dos métodos e implicava em saber

\footnotetext{
${ }^{59}$ O Decreto n. 1.253 de 28 de 11 de 1904 apresentou como uma das atribuições dos professores o comparecimento às festas escolares determinadas pelos diretores dos grupos escolares. Os diretores, em nome da autoridade atribuída, realizavam os exames e as festas escolares "de grande visibilidade pública", e também difundiam sua ação educadora por meio de conferências realizadas nas situações festivas (SOUZA, 1998).
} 
relacioná-los na realização dos festejos escolares. Ao contrário do que dizia o senso comum, a festa não poderia ser considerada um momento trivial do cotidiano escolar ou uma simples ruptura do calendário escolar. Para o seu preparo, reiteradas foram as prescrições apresentadas em leis e portarias, as fundamentações teóricas disseminadas pelos manuais ${ }^{60}$ e pedagogos escolanovistas, os exemplos publicados em periódicos de ensino, assim como as aulas ministradas nas escolas de formação de professores. Os saberes festivos, como se designa aqui, são os saberes que, de forma mais ou menos explícita, eram necessários aos professores e alunos para a realização das comemorações escolares. Dentre as suas funções educativas, caberia aos professores conhecerem e terem bem definidos quais eram os objetivos da festa, quais as suas funções e como prepará-las de maneira satisfatória, envolvendo a atividade e o interesse dos alunos e o que se poderia ensinar a partir delas para estes e para a população que delas participava.

Ao considerar os saberes dos professores, faz-se relevante assinalar que esses não se resumem às respostas das questões elaboradas anteriormente, tampouco às demandas relacionadas às atividades festivas, mas são complexos e plurais, além de se transformarem com o decorrer do tempo - histórico e de experiência docente. Se naquele contexto, para ser um bom professor era preciso conhecer bem os conteúdos dos currículos escolares e os métodos mais eficazes de ensiná-los, hoje, as questões que envolvem o trabalho docente são mais complexas e amplas, e fazem parte das pesquisas escolares e acadêmicas nos mais diversos países. As ponderações realizadas em estudos recentes acerca dos saberes dos professores, como o de Maurice Tardif (2011), propõe reflexões bastante férteis e que, respeitadas as diferenças temporais na elaboração das pesquisas, apresentam discussões pertinentes para a identificação e a compreensão dos saberes desses profissionais no período em questão. De acordo com Tardif (2011), é na elucidação das relações que estes saberes estabelecem com a própria história da profissão docente e com as instâncias que organizam a profissão, que o estudo dos saberes dos professores se torna possível.

\footnotetext{
${ }^{60}$ As referências às festas escolares não estão presentes em todos os manuais selecionados para este estudo, entretanto nos compêndios que assinalaram indicações sobre as mesmas foi possível perceber uma grande preocupação com a definição dos objetivos das festas - essas deveriam ser fundamentadas cientificamente como previa a pedagogia da época, com a organização das comemorações - um bom professor além de saber ensinar a ler, escrever e contar, também deveria saber festejar, com as atividades dos alunos e dos professores relacionadas ao preparo e execução das festas - atividades imprescindíveis para garantir o potencial pedagógico dos eventos e o aprendizado ativo dos alunos. De um total de oito manuais brasileiros e doze portugueses examinados, nove trouxeram referências às festas escolares.
} 
António Nóvoa (1992), ao discorrer sobre a organização histórica da profissão docente em Portugal, assinala que para a existência da profissão de professores foi necessário o cumprimento de alguns critérios fundamentais, que podem ser resumidos nos seguintes itens: 1) a instituição de leis organizadoras da profissão docente; 2) a dedicação integral ao ofício de mestre, ou seja, a ausência de funções paralelas a esse ofício; 3) a organização de instituições formadoras de professores, como as Escolas Normais e, por fim, 4) a criação de associações e sindicatos capazes de defender o professorado e elaborar diretrizes para a profissão. Neste sentido, é possível identificar semelhanças entre as ideias de Tardif (2011) e as hipóteses de Nóvoa (1992), principalmente quando o último afirma que a discussão sobre os saberes que circunscrevem a profissão dos professores deve possibilitar analisá-los no contexto mais amplo do estudo da profissão docente, de sua história e de sua situação no interior da escola e da sociedade. Considerando tais conceitos, não convém falar de um saber singular dos professores, como se este fosse uma categoria autônoma e separada das outras realidades sociais, organizacionais e humanas nas quais os professores se encontram; aliás, a partir das teorias de Nóvoa (1992), e Tardif (2011), não se pode falar a respeito do saber de qualquer profissional sem relacioná-lo aos seus condicionantes sociais e do contexto do trabalho: “(...) o saber é sempre o saber de alguém que trabalha alguma coisa no intuito de realizar um objetivo qualquer" (TARDIF, 2011, p. 11). O saber não é um conceito abstrato, que "flutua no espaço”, “(...) o saber dos professores é o saber deles e está relacionado com a pessoa e a sua identidade, com as suas relações com os alunos em sala de aula e com os outros atores escolares da escola etc" (idem, ibidem). Assim como os saberes sobre as festas se organizaram de forma pautada pelos objetivos políticos e sociais mais amplos, às questões escolares e de métodos, e ainda de valores, o saber docente se constituiu de forma relacional, e precisa ser estudado nessas intersecções.

Algumas características dos saberes dos professores podem ser identificadas considerando o papel central que assume a natureza social desse saber. Tais características podem ser evidenciadas, por exemplo, na sua partilha por um grupo de indivíduos que possuem uma formação comum (mais ou menos variável), trabalham em uma mesma organização e estão sujeitos as mesmas regras; na legitimidade desse saber construída nas universidades, sindicatos, ministérios, associações e orientadora de sua definição e utilização no contexto escolar; no caráter coletivo da definição dos saberes profissionais, que podem mudar com a história da profissão docente e os seus objetos 
sociais, isto é, suas práticas sociais, já que o professor "trabalha em um projeto: transformar os alunos, educá-los e instruí-los"; às questões relacionadas aos programas e à história das ideias pedagógicas que se alteram na história da educação e nos diferentes níveis de ensino e, por fim, a natureza social do saber dos professores se destacam por este ser adquirido no contexto de uma socialização profissional, "onde é incorporado, modificado, adaptado em função dos momentos e das fases de uma carreira, ao longo de uma história profissional onde o professor aprende a ensinar fazendo o seu trabalho" (TARDIF, 2011, p. 14). Todas as características sublinhadas se complementam e imbricam na constituição dos saberes profissionais dos professores.

Estes devem ainda ser compreendidos em relação ao seu trabalho em sala de aula; a utilização que cada professor faz dos seus saberes acontece em função do seu trabalho e das situações que se apresentam cotidianamente, além dos recursos físicos e materiais que têm a disposição e condicionam esse trabalho. O saber social, relacional e condicionado, é diverso e plural, porque envolve, no exercício do trabalho, conhecimentos e um saber-fazer bastante diversos, provenientes de fontes variadas e, provavelmente, de naturezas diferentes. É um saber temporal, pois é adquirido, transformado e ressignificado no contexto de uma história de vida e de uma carreira profissional compreendida como um processo temporal marcado pela construção do saber de cada educador. São saberes que ao se almagamarem fundem contradições, dilemas, tensões e conflitos cognitivos expressos, por exemplo, na hierarquização que os professores operam desses mesmos saberes (TARDIF, 2011). As formas pelas quais esses saberes se constituem distintamente caracterizam a própria profissão docente e são uma constante nos estudos históricos acerca da profissão de professor.

Ao ponderar tais características, assume-se que os saberes organizados acerca das festas escolares realizadas no Brasil e em Portugal na passagem do século XIX para o XX, também sofreram transformações de acordo com as condições sociais, institucionais, temporais, relacionais e experienciais de cada professor. As discussões realizadas neste capítulo indicam algumas possibilidades, mas não todas, de organização dos conhecimentos e das ações associadas aos rituais festivos nas instituições de ensino primárias nos dois países pesquisados. Assim como os saberes profissionais, os saberes festivos são sociais, temporais, relacionais, condicionados, diversos e plurais e precisam ser considerados nestas interrelações. Desse modo, o estudo sobre os saberes que se intercambiaram com a organização das atividades festivas, precisa se descolar das orientações oficiais, buscando, em outras fontes (manuais e periódicos, além de 
experiências docentes conhecidas), as formas de operacionalização dos mesmos nos contextos de ensino.

A inserção de novas práticas assim como de novas ideias acerca do processo de ensino e aprendizagem é indelével na constituição de uma cultura própria da escola e de uma representação ideal de professor em diferentes contextos sociais e históricos. As festas escolares emergem como uma nova atividade para a qual alguns professores poderiam não estar preparados; demandavam o cumprimento de novas regulamentações não apenas pelo simples fato de que elas existiam, mas também para mostrar o bom desempenho da escola (professores, alunos, diretores) na sua tarefa educativa, além de disseminar os saberes curriculares (disciplinas) e escolares (funções da escola e importância do ensino) para o maior número de pessoas.

Era por meio das comemorações escolares de diferentes tipos que a população e as autoridades presentes poderiam conferir a atuação dos professores no que diz respeito à sua competência às questões de ensino e sua dedicação aos alunos. Como exemplo, retoma-se a festa de aniversário da Escola Prudente de Morais que comemorou no dia 17 de agosto o segundo aniversário de sua instalação com "uma magnífica festa escolar em que mais uma vez ficou demonstrada a perícia do seu corpo docente" (A Eschola Publica, 15 de setembro de 1897, p. 277, grifos nossos). Em outras comemorações, como as de encerramento do ano letivo, a visibilidade dos trabalhos realizados pelos professores era ainda mais patente, constituíam-se situações nas quais os próprios profissionais poderiam ser avaliados a partir do desempenho dos seus alunos nas provas públicas, como ficou registrado na finalização das atividades escolares do ano de 1896:

As festas escolares que tão pálida notícia acabamos de dar foram honradas pela presença dos Exms. Snrs. Dr. Presidente e Vice Presidente do Estado, Secretário do Interior e outras autoridades superiores, que mostraram grande satisfação congratulando-se com o pessoal das escolas pelo adiantamento e progresso que dia a dia o ensino vai demonstrando, graças à solicitude com que é tratado pelos poderes públicos e à dedicação do professorado (idem, 15 de dezembro de 1896, p.425, grifos nossos).

As normas e legislações sobre os dias comemorativos poderiam ser uniformes para as escolas públicas de um determinado contexto histórico e social, mas a concretização dos discursos expressos nas circulares oficiais poderia transformar-se em saberes operacionais diferentes. Algumas distinções nas comemorações escolares eram condicionadas, por exemplo, pela localização das escolas - um grupo escolar da capital 
de São Paulo possuiria muito mais recursos e materiais para a realização da festa da árvore com todas as etapas previstas oficialmente do que uma escola isolada no mesmo contexto, por exemplo; pelos saberes dos alunos - os saberes cívicos exigidos dos professores e crianças das escolas primárias brasileiras na comemoração do sete de setembro eram de natureza diversa dos exigidos dos alunos e professores do ensino secundário e das Escolas Normais; pelo tempo dedicado aos ensaios e preparação da festa - que poderiam diferir, de acordo com o tempo disponível para o cumprimento do programa oficial; pela experiência profissional dos professores na organização dessa atividade - primeira ou quinta vez de seu ensaio e apresentação e, por último, pelas fontes de informações utilizadas para isso - mais teóricas ou práticas; no caso do nosso estudo, os manuais ou os periódicos, respectivamente. As nuances das prescrições festivas foram registradas nas páginas do Anuário de Ensino do Estado de São Paulo por ocasião da Comemoração do Centenário da Independência Brasileira em 1922 nas quais para as escolas mais pobres indicou-se apenas a realização da solenidade das nove horas, para as outras rituais mais elaborados:

a) Onde houver comissões regionais de escoteiros as cinco horas e meia, alvorada e hasteamento da bandeira nacional no acampamento e nos edifícios públicos. Onde for possível, deverão os escoteiros acampar de véspera, para a realização desta solenidade;

b) Às nove horas, festa escolar, que será iniciada com o juramento à bandeira feito por todos os alunos das escolas, obedecendo a uma fórmula que oportunamente, vos será enviada.

Por ocasião dessa festa deverão ser cantados o Hino Nacional, o Hino da Independência, o da Proclamação da República e o da Bandeira, devendo a solenidade terminar com o hasteamento do pavilhão escolar paulista, cantando, então, todos os alunos o Hino do Pavilhão. O pavilhão escolar deverá ser hasteado no mesmo mastro em que estiver hasteada a Bandeira Nacional, ficando colocado logo abaixo desta.

c) Ás 18 horas dar-se-á a solenidade do arreamento das bandeiras.

Nas escolas isoladas de localidades onde não seja possível a execução do programa com todas as partes acima, deverá, entretanto, ser realizada a festa escolar das nove horas (Anuário de Ensino do Estado de São Paulo, 1922, p. 303).

As orientações festivas poderiam mudar de acordo com as categorias das instituições de ensino (grupos escolares, escolas modelo, escolas isoladas, escolas reunidas) e também de acordo com o nível de conhecimento de cada aluno. Os programas deveriam variar e se adequar à faixa etária e ao desenvolvimento de cada classe, por exemplo, nas festas de encerramento da Escola Modelo e Jardim da Infância da Capital, Escola Modelo Caetano de Campos, Escola Modelo Prudente de Morais e 
Escola Complementar no ano de 1897 foram definidos dias e tarefas específicas a serem atendidas pelos professores e alunos de cada instituição para o encerramento do ano letivo. Nos dizeres do autor acerca da celebração efetuada pelas crianças e professores do Jardim de Infância: "encantadora foi essa festa e de saudosas recordações, principalmente para os pais que viram seus filhinhos apresentar em público o resultado de alguns meses de carinhoso cultivo", pois havia somente alguns meses que o Jardim da Infância tinha sido inaugurado. Depois de encerrados os trabalhos, "com brinquedos, pequenas poesias escritas principalmente para o ato, cantos e marchas, foram as crianças conduzidas em bondes especiais ao jardim público, onde pelas professoras foi oferecido aos seus alunos um lunch de despedida" (A Eschola Publica, dezembro de 1896, p.42223)

Na mesma edição da revista A Eschola Publica noticiou-se no dia 27 de novembro o encerramento das aulas da seção masculina da Escola Modelo "Caetano de Campos" e da Escola Complementar. A comemoração teve início ao meio dia em todas as salas com a execução do programa, "que constava de cantos, exercícios orais sobre as disciplinas estudadas durante o ano, exercícios de declamação etc". A concorrência dos visitantes foi grande, "principalmente das famílias dos alunos, que felicitaram calorosamente os professores e os resultados obtidos. Em cada sala encerrou-se a solenidade pela distribuição dos boletins de promoção e prêmios oferecidos pelos professores aos seus alunos". Naquele mesmo dia, o encerramento das aulas a Escola Modelo 'Prudente de Morais' que como na instituição precedente constou de "uma prova geral em cada uma das salas, e finalizou por uma sessão musical e literária na sala de honra (...)" (ibidem).

Nas seções femininas da Escola Modelo "Caetano de Campos" e da Escola Complementar, no dia 28 de novembro, realizou-se em cada uma das salas uma festa "parcial, com bem organizados programas, finalizando pela distribuição de boletins de promoção". Depois de terminadas as festas parciais, todas as alunas seguiram para o salão de honra da escola, onde se realizou uma "sessão literária e musical, sendo cantadas músicas escritas especialmente para essa solenidade" (A Eschola Publica, dezembro de 1896, p.423). Por fim, a maratona de festas terminou no dia $30 \mathrm{com}$ um "torneio ginástico das três escolas modelo, a que concorreram também os alunos da Escola Normal e do Ginásio do Estado" (idem, p.424). Neste torneio houve a distribuição de medalhas de ouro aos melhores alunos e times. A definição de dias diferentes para as solenidades de encerramento do ano letivo das mais conhecidas 
instituições de ensino na capital paulista a época e, posteriormente, a publicação pormenorizada dos detalhes das celebrações assinalaram a preocupação dos profissionais do ensino a competência da escola e dos professores no desempenho das funções educativas escolares e, ainda no âmbito político com a divulgação do lugar ocupado pela instrução no novo regime. Era preciso dar a conhecer a toda a população o novo sistema de ensino, as hierarquias e os tipos de escola.

Nesta direção, é importante demarcar as distinções existentes entre os saberes festivos divulgados nos manuais e nos periódicos. Nos manuais de ensino, os professores puderam buscar todo o referencial teórico e metodológico que justificasse a organização das atividades festivas. Às perguntas do tipo: Como? Para quê serve a festa? Quais seus componentes constitutivos? Quais suas funções políticas, sociais e de ensino? Qual a técnica adequada para organizá-la?, foram divulgadas respostas de forma mais ou menos detalhadas nos manuais de ensino. Em suas páginas, os educadores poderiam encontrar elementos teóricos que fundamentassem a realização das comemorações no âmbito escolar, naqueles autores que discutiam direta ou indiretamente o tema, ou na apresentação de conteúdos e métodos a serem desenvolvidos por meio das festas. De outra forma, as notícias encontradas nos periódicos de ensino, incidiam muito mais no saber prático e experiencial das festas do que em teorizações sobre as mesmas, ou seja, nas páginas dessas fontes registravam-se as festas como deveriam acontecer de modo objetivo, por intermédio da publicação de programas, circulares, exemplos de textos, poesias e peças que poderiam ser encenadas, e ainda por meio de relatos de como as comemorações realmente aconteciam nas diferentes escolas. Por meio das experiências de outros professores em outras instituições de ensino relatadas nos periódicos, os educadores teriam ideia de como organizar e do que se esperar de uma festa de sucesso, especialmente, no que se referia ao seu potencial educativo e de expressão social.

Os manuais de ensino, assim como os periódicos escolares assumem, segundo Carvalho (2006), funções meta-normativas, ou seja, os discursos pedagógicos inscritos nos materiais didáticos em uso nas escolas sinalizam normas e prescrições pedagógicas que, como um sistema de regras, constituem o campo, os objetos e os objetivos das práticas e dos saberes escolares, além de regularem os processos materiais de produção, difusão e apropriação desses saberes. A profusão de iniciativas para a criação de periódicos educacionais e de manuais de ensino visíveis em todo o século XIX 
pretendia trazer sistematização, eficácia, e mesmo cientificidade àquela escola até então incipiente.

Para garantir a expressão social desejada aos eventos festivos escolares era necessário que estas festas não estivessem circunscritas a temas e datas específicas das instituições de ensino, mas que corroborassem episódios e personagens relevantes para a sociedade da qual fazia parte. Sendo assim, os primeiros saberes que condicionaram os fazeres festivos dos professores, diziam respeito às datas de festas e feriados nos contextos educacionais brasileiro e português, ou seja, aos seus respectivos calendários sociais e, a partir desse, aos calendários escolares instituídos. As escolas poderiam acrescer novas datas ao calendário social, como realmente foi feito nos casos das festas de aniversário, inauguração de escolas e de encerramento do ano letivo, mas nunca suprimir ou deixar de comemorar algum fato importante do calendário nacional, nem que fosse por meio de um simples discurso feito pelos mestres aos seus alunos no dia solenizado.

As discussões acerca das datas mais significativas para a história do país, bem como dos nomes de cidadãos que deveriam figurar no calendário nacional relacionamse nos países investigados com duas questões sociais e governativas marcantes: primeiro a separação, que se desejou definitiva, entre o Estado e a Igreja, a ser marcada na organização de um calendário de feriados e festas adjetivadas cívicas e, como desdobramento dessa primeira ação, o projeto de disseminação do ideário político republicano por meio das comemorações oficiais ${ }^{61}$. No caso do calendário de festas escolares, as prescrições e a atuação legal do Estado sobre as mesmas, coincidiram com o momento de constituição dos sistemas públicos e estatais de ensino primário, nos últimos decênios dos séculos XIX e primeiros do XX. No período em questão, os debates acerca das datas a serem celebradas e os modos de fazê-lo pela instituição escolar, marcaram a transição do poder da Igreja sobre as instituições de ensino para o Estado, bem como a apresentação do modelo republicano de governo como o mais adequado para o desenvolvimento dos países e dos seus cidadãos.

Junto às tentativas de se ordenar um Estado moderno, sobressaem-se os desafios de se construir uma escola moderna, com representações modernas sobre o tempo. As notáveis heranças da colonização

\footnotetext{
${ }^{61}$ No caso do estado brasileiro, a ruptura que se pretendia total não aconteceu e prevaleceu no calendário republicano datas cívicas dos diferentes regimes/períodos políticos (colônia, império e republica) e datas religiosas, que apesar de não comemoradas pela escola deveriam ser respeitadas como feriados (LEAL, 2006).
} 
portuguesa no Brasil, que fizeram da Igreja Católica uma instituição cujo domínio exercido é inegável, com seus ritos e festas, são evidentemente imprescindíveis para a melhor compreensão dos modos de construção do tempo escolar, mas deve-se sublinhar que tais heranças são observadas em diversos países. Nos países de tradição católica, a escola, para impor um tempo soberano, precisou enfrentar a soberania dos tempos da Igreja (GALLEGO, 2008, p. 97).

Além de indicar a ruptura que se pretendia assinalar entre a Igreja e o Estado, a seleção e a inserção de datas a serem celebradas em festas no âmbito escolar precisam ser analisadas à luz das discussões que se faziam na época acerca da construção da memória republicana na passagem do monarquia/império à república (1889, no Brasil e 1911, em Portugal), bem como a atuação dos responsáveis que se dedicaram a essa construção. Os embates em torno da organização do tempo civil e escolar não eram menores ao se considerar que a constituição de um calendário pode ser analisada "como um exemplo extremo de que controlar o tempo se torna essencial ao poder" (OLIVEIRA, 1989). A organização dos calendários regula a vida de toda uma sociedade, de um povo e de uma nação, bem como os mais restritos e a ele relacionados, calendários escolares (GALlego, 2008). Conjugados ao calendário civil e religioso do país, esses signos temporais normatizaram o cotidiano da escola e de seus sujeitos, assim como todo transcurso de uma trajetória escolar (TEIXEIRA, 1999).

A definição das datas a serem comemoradas em um calendário cívico para toda a nação teria seu êxito ameaçado se organizada somente pelos reformadores republicanos; o apoio dos professores e de outros especialistas, como os historiadores, os publicistas, os ideólogos e os doutrinadores transformar-se-ia em condição imprescindível no projeto de construção da memória nacional ao indicar os episódios históricos, os heróis e os símbolos que não deveriam ser esquecidos (OLIVEIRA, 1989). Afinal, era pela representatividade e pelo simbolismo que envolvia cada data, que a população poderia aprender sobre o que era a nação, a república, os heróis nacionais, os valores, a organização social, a escola e o seu desígnio para o futuro dos cidadãos. Aos professores, caberia a responsabilidade pela transposição das regulamentações oficiais, dos símbolos abstratos, do imaginário social idealizado em espetáculos escolares concretos para serem vistos, sentidos e apreendidos, indicando a consolidação de um calendário mais restrito e homogêneo no âmbito escolar ${ }^{62}$. Neste sentido, conhecer as

\footnotetext{
${ }^{62}$ Ainda com relação aos calendários escolares, faz-se relevante assinalar a permeabilidade existente nos mesmos no contexto do império brasileiro, que poderiam ter os dias de feriado e os dias santos alterados
} 
prescrições inscritas nos manuais utilizados nos cursos de formação de professores e, posteriormente, as notícias veiculadas nos periódicos de ensino sobre a concretização dessas orientações, nos permitem aquilatar quais foram os saberes festivos que se relacionaram às práticas docentes para a construção de uma memória histórica nacional.

Com a mudança de regime, a discussão sobre o calendário civil atualizou-se; era preciso marcar no tempo social, a cisão que se pretendia entre o Estado e a Igreja, e a escola, como parte do projeto de laicização social, deveria celebrar as datas cívicas. O gradativo detalhamento do calendário e, especialmente, a determinação dos dias de festas e comemorações escolares, integraram as ações para se consolidar um sistema de ensino homogêneo, além de constituírem-se em uma das tentativas para se controlar as atividades escolares no momento de organização do sistema de ensino estatal, informando aos alunos e aos professores as formas de trabalhar os dias de aulas, de modo a tornar a sua utilização o mais produtiva possível, sendo a produtividade representada por mais conteúdos ensinados e aprendidos no menor tempo possível pelo maior número de pessoas (GALLEGO, 2008). Era necessário desencadear emoção, encontrar símbolos dos fatos que desejavam recordar e provocar sentimentos, para que as crianças aderissem a eles, aos novos valores, com paixão e, ao mesmo tempo, distanciar-se dos rituais e símbolos da Igreja.

A inserção das datas comemorativas nesse calendário escolar significou não um momento de ruptura no desenvolvimento das atividades escolares, como muitos procuram afirmar, mas um tempo também de aprendizado dos conteúdos e valores escolares legitimados socialmente ${ }^{63}$, ao eleger e selecionar datas a serem festejadas e homens (e mulheres) a serem considerados heróis; indicou o que deveria ser lembrado e, consequentemente, aquilo que deveria ser esquecido. A festa dava continuidade e confirmava tudo aquilo que era aprendido nos bancos escolares. Em sua temporalidade específica, a festa demonstrou seu caráter político e pedagógico, ao destacar os feitos

de um ano para o outro e ainda acrescidos de eventos religiosos, políticos ou sociais esporádicos (GALLEGO, 2008).

${ }^{63}$ Em virtude da crescente participação do Estado na educação, os processos educativos, a estrutura organizativa das escolas, a exemplo do calendário, passaram a ser mais racionalizados (GALLEGO, 2003). As datas para o início e término das aulas, férias e comemorações foram fixadas. Com outro modo de estruturar o tempo, as atividades dos professores e alunos foram cada vez mais reguladas, e estes eram submetidos a uma nova relação com o tempo. Os calendários, conforme destaca Teixeira (1999, p. 96), são um dos principais referentes temporais da escola e da experiência do tempo dos professores, já que estruturam e revelam a rítmica das práticas e atividades de professores e alunos nos tempos cotidianos. 
políticos no âmbito educacional e confirmar a importância da escola entre pais, alunos e professores para a sociedade brasileira e portuguesa da época.

O tempo da festa não era menos rígido do que o tempo da escola; a festa tinha hora de início, de fim, das homenagens, das apresentações dos alunos, do teatro, da entrega dos prêmios, dos exames e dos discursos dos professores e autoridades escolares; enfim, tudo estava programado. Sendo assim, pode-se dizer que o tempo da festa era também um tempo rígido, como os dias regulares de aulas, não era um tempo livre mas de exteriorização dos saberes adquiridos em sala de aula. A festa representou outro uso do tempo de aprendizagem escolar; aprendia-se e ensinava-se em um contexto diferenciado e marcado, de certa forma, pela descontração, alegria e espontaneidade, mas que não deixava de lado, por esses traços, seus efeitos disciplinadores e moralizadores. Para cada ação no contexto festivo existiu um conjunto de regras e um tempo destinado para cada uma, assim como para cada data um programa mais ou menos demorado dependendo da sua relevância social e de sua complexidade ${ }^{64}$. Neste sentido, ao tratarmos das comemorações escolares, deve-se atentar para as distinções existentes entre as festividades que ganharam espaço e tempo no calendário das escolas primárias e, portanto, adquiriam diferentes funções, sentidos e modos de comemorar.

Além da busca do controle e da racionalização do tempo escolar, as festas indicaram questões importantes relacionadas à visibilidade permitida por elas. Era nas ocasiões festivas que a instituição de ensino, os alunos, os trabalhos realizados e a figura do professor ganharam maior evidência social, caracterizando a visibilidade panóptica de tais eventos. Aos saberes festivos estariam associados, desse modo, a imagem que o professor desejava apresentar de si, os resultados escolares verificados no aprendizado dos alunos e, em um âmbito mais geral, da própria profissionalização e dignificação social da atividade docente. As mudanças engendradas em âmbito mundial para a constituição de um modelo escolar, democrático, laico, estatal e público de ensino não se fizeram sem uma constante preocupação acerca do profissional ideal para o contexto escolar que se organizava.

A fim de homogeneizar a escolha das datas, e até mesmo, evitar o uso excessivo dessas no ambiente escolar, alguns textos legais foram produzidos para regulamentar os dias de festas nas instituições públicas de ensino, além da publicação de

\footnotetext{
${ }^{64}$ As festas do centenário foram realizadas em vários dias e noticiadas por um longo período e em diferentes veículos após a sua realização, diferente de outras situações para as quais as sessões cívicoliterárias poderiam ser suficientes ou até mesmo uma singela apresentação musical.
} 
textos e discursos norteadores nos manuais e periódicos de ensino. A definição racional e sistematizada do calendário escolar e, com ele, dos dias de festa, fez parte de um projeto modernizador mais abrangente, fundamentado cientificamente e identificado nas propostas inovadoras de formação e atuação profissional. Circunscrever a ação do professor e fundamentá-la a partir de prescrições cientificamente provadas e testadas foi a forma colocada em prática para a consolidação do modelo "profissional" de professor, baseado na separação racional entre conhecimento teórico e prático, alargamento dos conteúdos acadêmicos, domínio de métodos específicos e aquisição de uma identidade profissional, em detrimento de um modelo "artesanal" da formação de professores, baseado na tradição e imitação presente na história da educação brasileira até meados do século XIX (VILLELA, 2002).

Não era suficiente que os professores atendessem as novas demandas meramente por formalismo, mas que compreendessem suas funções educacionais, sociais e práticas educativas a partir de argumentos racionais e científicos, para que assim pudessem também "preparar jovens para conviverem civilizadamente com seus semelhantes, participarem das decisões, ou acatarem-nas não pela obediência cega, mas pelo consentimento" (VILlELA, 2002, p. 13). Tratava-se de um processo longo de transformação, que percorreu todo o século XIX, dos currículos das instituições de formação de professores (as Escolas Normais), e que teve como seu ponto alto, o movimento de renovação educacional empreendido pelos precursores da Escola Nova. As fundamentações científicas sobre a potencialidade educativa das comemorações escolares foram demoradamente tratadas nos manuais do período, que as associaram, por exemplo, a escolha dos melhores métodos de ensino, aos conteúdos a serem ensinados e aos benefícios da emulação presentes nas homenagens e entregas de prêmios aos considerados melhores alunos.

As prescrições festivas influenciaram diretamente o trabalho dos professores, ao qual caberia orquestrar tais eventos organizando-os da maneira mais fértil e mais próxima possível dos objetivos educativos. A inserção de uma nova função, de saberes e fazeres associados a essa - organização das festas escolares determinadas legalmente, influenciou de maneira indelével a identidade docente ${ }^{65}$, as representações que possuíam acerca de si e da sua profissão, bem como das representações sociais sobre as instituições de ensino. Tarefas que até então não se faziam presentes no cotidiano das

\footnotetext{
${ }^{65}$ Sobre a questão da identidade docente foram essenciais as discussões de Martin Lawn (2000) e a produção de António Nóvoa (1992).
} 
escolas, como preparar grupos de alunos, agora divididos em idade e nível semelhante de conhecimento, participar coletivamente de comemorações, difundir valores cívicos e aqueles referentes a uma nova cultura escolar mediante o cumprimento das propostas pré-estabelecidas pelas autoridades educacionais foram demandas que alteraram o cotidiano escolar e a profissão do professor. A partir daquele momento, a proposta de ser professor integrou as maneiras ideais de festejar e celebrar, transformando a sua identidade ${ }^{66}$ e a sua prática docente.

As identidades dos professores são construídas a partir de referências provenientes de várias instâncias sociais, das quais se destacam as advindas do Estado em uma tentativa de controlar o trabalho docente, principalmente por meio dos discursos oficiais produzidos internamente e divulgados, por exemplo, nos discursos proferidos nas ocasiões solenes, "traduzindo-se num método sofisticado de controle e numa forma eficaz de gerir a mudança” (LAWN, 2000, p. 69). A associação da identidade dos professores à identidade nacional, entendida aqui como a de um determinado país em um contexto histórico específico, é frutífero para se compreender determinadas fases de desenvolvimento do ensino público e estatal, em qualquer nação. O Estado cria uma versão "utilizável" de um projeto de educação nacional, e neste projeto é muito comum atrelar-se as expectativas em relação à identidade docente aos objetivos econômicos ou sociais.

Sem dúvida, a identidade dos professores, assim como observa Lawn (2000), tem constituído uma parte importante da gestão do sistema educativo, sendo um item sempre presente nas descrições oficiais, nos artigos sobre mudança na educação, nos manuais pedagógicos e nos relatórios nacionais produzidos (tanto brasileiros quanto portugueses). O esforço estatal de se fixar a identidade dos professores fica evidente mediante os apelos à sua função social (LAWN, 2000). Na verdade, o Estado recorre a uma série de referências acerca do tipo "ideal" de professor, quer seja em relação as suas qualidades morais e sociais, quer seja sobre suas virtudes e capacidades, que atenda ao projeto de educação vislumbrado. Sendo assim, as festas constituem importantes momentos nos quais o Estado, ao determinar seus conteúdos e datas a serem comemoradas, pode disseminar um ideal de cidadão não só para a população que assiste

\footnotetext{
${ }^{66}$ Parte das reflexões apresentadas aqui foi elaborada por ocasião do IV Congresso Brasileiro de História da Educação em 2006 pela autora e por Rita de Cássia Gallego, sob o título: "Engendrar tempos e identidades: as festas no calendário escolar e suas implicações para a organização dos professores".
} 
a tal solenidade, mas também para os alunos e professores que participam de todo o processo de organização da mesma.

Por outro lado, o processo de construção da identidade não pode ser compreendido como um dado adquirido, uma propriedade e, tampouco um produto; ao contrário, “é um lugar de lutas e de conflitos, é um espaço de construção de maneiras de ser e estar na profissão" (NóvoA, 1992, p. 16). Portanto, segundo este autor, é mais prudente falar em processo identitário, destacando a mescla dinâmica que caracteriza o modo como cada um se sente e se diz professor. Tal construção consiste num processo complexo, pelo qual cada um se apropria do sentido da sua história pessoal e profissional; por isso, necessita de tempo para refazer identidades, para acomodar inovações e para assimilar mudanças que alteram sobremaneira a cultura profissional docente, compreendida, principalmente, a partir dos textos dos manuais pedagógicos, como um amplo conjunto de elementos. Dentre estes estão as tarefas cotidianas na sala de aula, a convivência com os alunos, as conversas entre colegas, a partilha de uma identidade comum, a integração de experiências pessoais às atividades de trabalho, bem como a assimilação de valores, competências, crenças, hábitos e informações que buscam instaurar modalidades de interpretação e ação junto às situações de ensino (PerRenoud, 1993).

Os discursos proferidos pelos educadores ${ }^{67}$ e outras pessoas que ocuparam cargos de destaque nas sociedades brasileiras e portuguesas no período investigado buscavam influenciar, nas situações festivas, a construção das maneiras de "ser e estar na profissão" docente por meio do uso de prescrições e metáforas ${ }^{68}$ associadas à profissão. Estes discursos constituíram parte importante dos festejos, substituindo, não poucas vezes, as descrições das festas nos periódicos de ensino, assim como

\footnotetext{
${ }^{67}$ Foi realizado por Márcia Shaeffner e por mim um levantamento e análise dos discursos de educadores publicados na Revista de Ensino entre os anos de 1902 e 1918. Ao todo foram selecionados 72 discursos, organizados em três grandes temas para análise, são eles: a presença das metáforas religiosas para definir o trabalho e a carreira docente e sua ambigüidade com relação à luta da categoria por melhores condições de trabalho; as questões relativas a finalidade da educação e a educação moral e cívica das crianças e da sociedade; a utilização da ciência no discurso pedagógico para justificar a adoção de novos métodos de ensino. O trabalho foi apresentado na Semana de Educação da FEUSP no ano de 2005.

${ }^{68}$ A presença das metáforas educacionais nos discursos selecionados para análise indicou, como propõe Scheffler (1974), aquilo que se pensa serem paralelos significativos, analogias e similaridades existentes no interior do tema do próprio discurso. As afirmações metafóricas exprimem, muitas vezes, verdades significativas e surpreendentes, à diferença das estipulações, que não exprimem absolutamente nenhuma verdade e, em contraste com as definições descritivas, que normalmente não surpreendem: "A afirmação metafórica indica a existência de uma importante analogia entre duas coisas, sem dizer explicitamente em que consiste a analogia" (SCHEFFLER, 1974, p.60). Para que a afirmação metafórica seja julgada valiosa ou apropriada, a analogia sugerida deve ser importante com relação a critérios que sejam relevantes no contexto da sua elocução.
} 
aconteceram com as fotografias. Percebeu-se que ao tratarem de temas não só relacionados à data festiva, mas também de questões educacionais mais amplas como, por exemplo, a função da educação, a "missão do educador", o aluno "ideal” e a crise moral que ameaçava a sociedade, estes discursos almejaram forjar uma identidade docente e o próprio aluno, além de construir um modelo de vida escolar que ultrapassasse os muros das escolas e conformassem outros âmbitos da vida social. Estes saberes, veiculados nos discursos proferidos, ao contrário dos outros momentos da festa, eram destinados principalmente aos adultos, pais e professores presentes em tais ocasiões, que podiam compreender de forma mais aprofundada as mensagens transmitidas. Aos alunos caberia sentir a ocasião, cultivar os sentimentos e aprender os valores.

As festas apelaram, ao mesmo tempo, para o racional e o emocional daqueles que delas faziam parte, como demonstrou o discurso de Antonio Alves Aranha, diretor da Escola Complementar de Campinas, por ocasião da formatura da primeira turma de professores daquela escola, em 1906. Naquele texto, o autor destacava a magnitude de tal festa, a sua significação e seu alcance, pois era um dia "cheio de esperanças", no qual a Escola Complementar de Campinas entregava ao Estado de São Paulo "a sua primeira falange de evangelizadores da grande causa do ensino que se identifica com a grande causa da democracia, com a causa da pátria e da civilização" (Revista de Ensino, junho de 1907, p. 11), os primeiros professores que iriam levar através do povo "o evangelho luminoso da instrução". Neste dia "de triunfo de um compromisso de honra", os professores deveriam estar preparados para as dificuldades que encontrariam na profissão, mas ao mesmo tempo, satisfeitos pela grandeza da "nobre missão":

$\mathrm{Na}$ senda do altruísmo que tendes a percorrer, encontrareis espinhos e escabrosidades entrecortados de flores plantadas em planos aparelhados pelas mãos dos que bem sabem compreender os serviços de um mestre; e nesse caminhar constante, nessa luta que muitos chamam inglória, recebereis alternativamente o bálsamo consolador e o cálice de amargura como recompensa do vosso trabalho (Revista de Ensino, junho de 1907, p. 12).

As alocuções apresentaram a profissão docente como uma nobre missão, um "ministério" e também um "sacerdócio", os textos dos impressos educacionais, por exemplo, são imbuídos de qualidades a serem observadas nas práticas docentes, tais como pontualidade, cumprimento das obrigações, respeitar o tempo destinado a cada atividade, disciplina etc. O professor, um sacerdote, pastor, evangelizador, apóstolo seu modelo deveria ser, nas palavras de D. Maria Reis - professora do Grupo Escolar de 
S. Simão - (Revista de Ensino, 1907), o dos "apóstolos de Cristo", ou o próprio "Divino Mestre", como enfatizou João Lourenço Rodrigues, que foi professor, membro da Associação Beneficente do Professorado Público de São Paulo e Inspetor Geral da Instrução Pública do Estado de São Paulo, entre os anos de 1907 e 1909 (Revista de Ensino, 1914). Os alunos faziam parte do rebanho do mestre "pastor", o saber era a "hóstia santa" e o "luminoso evangelho" do templo ou "luminoso recinto" era a escola. A dignidade de seu trabalho indicava a postura esperada dos professores nas adversidades. As metáforas cristãs, ao retratarem a docência como apostolado, ressaltaram a importância que assumia, para aqueles que a exerciam, a convicção de que aquilo que ensinavam era indispensável para os alunos. De fato, um professor que não acreditava na relevância daquilo que ensinava para a vida de seus alunos estava, no mínimo, a meio caminho do fracasso. Referindo-se a história da profissão docente de Portugal do século XIX, Rogério Fernandes (1998) assinala questões muito importantes para a sociedade portuguesa e compartilhadas pelos dois países objeto desta pesquisa:

o professor primário tornar-se-ia o sacerdote de uma nova ordem política, o difusor de um novo sistema de crenças e valores assente no livre-pensamento. A sua credibilidade ético-social passaria pela austeridade e rigor dos costumes mas também pela modicidade dos vencimentos, reduzido ao pão nosso de cada dia e nada mais.

Posto ao serviço da revolução republicana, em primeiro lugar, ou da própria República, em seguida, o exercício da profissão ficou desde então associado ao paradigma do professor missionário, capaz de sacrificar ou abandonar ambições pessoais legítimas, mantendo-se à margem de qualquer atividade reivindicativa, em troca de um destino profissional reputado transcendente.

O desenvolvimento do sindicalismo docente, por sua vez, veio recusar, justamente, um modelo profissional que se afirmava na exigência de uma auto-anulação (FERNANDES, 1998, p.12).

Uma das tarefas consideradas primordiais na "missão do professor", para além do ensino dos conteúdos, foi a formação do caráter dos educandos, entendida como formação moral do "bom cidadão" e da "boa mãe". Neste sentido, cabe retomarmos o discurso de José Feliciano de Oliveira, que representou de forma exemplar a opinião dos educadores cujos discursos sobre esse tema foram registrados nos periódicos de ensino. Nas palavras daquele professor, o verdadeiro sentido da educação era justamente a formação dos cidadãos, sendo o civismo o mais alargado sentimento social, que formaria a "simpatia universal" e a união dos povos. "Ser um bom cidadão é a maneira mais decisiva de ser um bom homem, um homem social" (Revista de Ensino, 1903, p. 1107). 
Caberia aos educadores encaminhar metodicamente o espírito dos alunos, fortalecendo-lhes a vontade: "Enfim, antes de tudo, tratai de saber como se educa instruindo. Formai uma idéia segura do que seja a educação verdadeira e buscai sistematizar um conjunto de meios para realizá-la com a instrução" (idem, ibidem). Os professores, nas "suas sagradas missões", deveriam resguardar a escola infantil com uma vigilância sempre desperta, para que seus alunos não se contaminassem com esta epidemia, educando e instruindo ao mesmo tempo. A educação moral, na opinião dos educadores da época, deveria ser o preâmbulo obrigatório de todo sistema educativo, que só poderia ser alcançada com o auxílio da família, considerada como um elemento imprescindível para o sucesso do ensino (Revista de Ensino, novembro de 1907).

A preocupação com a crise moral expressa nos discursos de alguns educadores que ameaçava a sociedade e a escola, foi tema recorrente nos discursos proferidos nas ocasiões festivas. De acordo com João Lourenço Rodrigues (1904), essa crise moral se assinalava, principalmente, no domínio especulativo do ceticismo, pela inconsistência das opiniões e das doutrinas, pelo desterro do entusiasmo e pela ausência de idealismo representado no pessimismo, considerado como a mais terrível epidemia moral da época.

numa época como esta não basta instruir e sobrecarregar a mente infantil de noções abstratas, sem eficácia para regular a conduta individual; o que importa é educar, e para educar é imprescindível promover o surto dos sentimentos bons (...) Não basta instruir; quem instrui, sem despertar o espírito, sem aprimorar-lhe as faculdades, constrói sobre a areia (...) (Revista de Ensino, outubro de 1904, p. $385)$.

As questões relativas à finalidade da educação e a educação moral e cívica das crianças e da sociedade, assinalada na preleção de João Lourenço Rodrigues (1904), estiveram presentes em outros textos publicados na Revista de Ensino (1902-1918). Este periódico destacou-se pela publicação dos discursos proferidos em ocasiões festivas que, muitas vezes, substituíram as descrições das comemorações realizadas. A formação do caráter e da moral esteve associada à formação do cidadão republicano nos discursos publicados e era um saber a ser apropriado pelos professores e ensinados aos seus alunos. Os exemplos do mestre, dos alunos, bem como dos grandes nomes da história do Brasil também serviriam ao ensino do civismo e da moralidade. Foi por este motivo que se disseminou a idéia de que a profissão docente não poderia ser exercida por todos, já que o professor deveria ser um modelo de conduta exemplar aos seus "discípulos". 
Nas palavras do inspetor de ensino paulista, Carlos A. Gomes Cardim (1908), em todos os atos dos alunos percebia-se, sempre, o reflexo do mestre, porque este "pela sugestão, incute-lhe todas as qualidades que possui" (Revista de Ensino, março de 1908, p.31). Além de ser um exemplo de boa conduta, um bom professor, segundo Dino Bueno, era aquele que praticava sua "missão" com amor, já que este era o princípio criador de todas as coisas, inclusive de homens para a sociedade (Revista de Ensino, março de 1906, p. 807). Por outro lado, um mau mestre representava um "perigo social de consequências desastrosíssimas", influenciando seus alunos que, em seu convívio imediato, tornavam-se verdadeiros "veículos de propaganda" das qualidades “deploráveis do seu mau guia”; desse modo, segundo o autor, era possível a partir da observação do comportamento das crianças, perceber as qualidades e defeitos do seu mestre.

Em situações consideradas de "pânico moral" acerca da sociedade e das suas crianças, ou de transformações sociais mais significativas, como foram os processos de implementação dos sistemas públicos e estatais de ensino em Portugal e no Brasil, os professores assumem um lugar de destaque (LAWN, 2000). Nesse caso, quase sempre a identidade docente aparece como inadequada e é urgente a mudança. No período tomado para estudo, foi recorrente nos discursos, o tom de insatisfação com esses profissionais e os apelos para que mudassem suas práticas e incorporassem as sugestões difundidas nos periódicos educacionais e nos relatórios de inspeção, por exemplo. Sem dúvida, a identidade dos professores, assim como observa Lawn (2000), tem constituído uma parte importante da gestão do sistema educativo, sendo um componente sempre presente nas descrições oficiais, nos artigos sobre mudança na educação e nos relatórios produzidos. A fixação de uma identidade para os docentes, através dos discursos e regulamentações, funciona como uma forma profícua de se estruturar ou reestruturar o trabalho (LAWN, 2000) como indicou o discurso do professor paulista José Feliciano em 1906:

Nossa época perturbada, desiludida, precisa de haurir no passado exemplos viris e preparações reais, que nos levem a reconstituir, a melhorar a sociedade nova que nos domina (...) Não é de formas novas, de novas aparências que há de vir remédio educativo e regenerador a nossas mazelas sociais (...) Ora, é de educação moral e intelectual, é do civismo que a atividade social tira a melhor, a mais completa base de seu exercício realmente útil (Revista de Ensino, setembro de 1906, p. 46). 
$\mathrm{O}$ fato de alguns professores não se adequarem às identidades oficiais pode preocupar quem dirige a nação e o ensino, por mais que se saiba das subversões possíveis (Lawn, 2000). Há um esforço notável para circunscrever as práticas no interior das escolas, haja vista a quantidade de prescrições voltadas aos docentes, percebida em diferentes veículos de informação educacionais no decorrer da história da educação. Todas essas recomendações presentes nos discursos oficiais, considerados como os discursos de indivíduos em cargos de destaque no campo educacional e concebidos como um saber de referência, apresentaram um modelo de profissional e de profissão docente que até então não era almejado como modelo a ser perseguido. Esses discursos, ao serem pronunciados em comemorações festivas ou ocasiões especiais denotaram a importância desses ensinamentos não só para os professores que deveriam conhecê-los e praticá-los, mas também para os pais e sociedade em geral, que deveriam cobrá-los dos mestres de seus filhos.

As situações festivas exigiram dos profissionais do ensino não somente a elaboração dos saberes e fazeres necessários à sua efetivação no âmbito escolar, mas também um conhecimento da identidade docente engendrada nas intersecções entre o ideal de educador projetado oficialmente e o real possível que se deveria divulgar para a sociedade. A festa tornou-se o momento de visibilidade social dos trabalhos escolares, da competência dos docentes para a organização dos eventos e, por fim, da imagem de professor mais ou menos próxima do ideal almejado. Por meio das festas escolares era possível, nas palavras de João Beckmaum (1904), demonstrar o desenvolvimento e o progresso das escolas públicas republicanas para os professores, alunos, pais e sociedade, para que não houvesse, assim, nenhuma dúvida acerca da qualidade das mesmas. Era preciso, à medida que fossem surgindo escolas-modelo e grupos escolares, que

(...) também surgisse e fosse logo posta em prática a idéia de tornar bem patente e clara e excelência da nova processologia aplicada ao ensino (...) Surgiu então, a feliz idéia das festas escolares no fim de cada no letivo, pelas quais se pudessem tornar bem frisante o desenvolvimento admirável e real das crianças educadas nas primeiras escolas-modelos e grupos escolares criados (Revista de Ensino, dezembro de 1908, p. 35).

Dos professores eram exigidos os papéis de homens e mulheres exemplares, cidadão e profissional ideal; afinal, era por meio das suas ações profissionais que o sucesso ou o fracasso das futuras gerações, o bom desenvolvimento do ensino e o 
progresso da instrução pública, laica e democrática poderiam se realizar. Referências à boa conduta moral, aos bons costumes, a modéstia, ao zelo, à pontualidade, à honestidade ao bom senso e ao civismo do educador ocuparam boa parte das prescrições feitas aos mestres nas páginas dos periódicos e dos manuais de ensino. Para o educador J. Augusto Coelho (1907), o professor era "o elemento mais ativo e importante da operação educativa e docente" (p. 34); era dele que dependia a educação e o ensino, nas palavras de Leitão (1915). A docência era apresentada como uma profissão exigente que implicava um percurso de formação, para além de um perfil adequado. O saber-ser profissional associou-se à imagem que o professor deveria perseguir e apresentar em uma aproximação ideal entre a escola (compreendida na sua integralidade, professores, funcionários, diretores, inspetores) e a sociedade (representada pelas famílias dos alunos) para a formação do "futuro cidadão do país", sendo que caberia aos docentes responsabilizar-se por este desígnio.

No âmbito das discussões acerca da atividade profissional dos professores coabitaram orientações de duas áreas diferentes e teoricamente antagônicas: a religião e a ciência. É curioso perceber como o Estado se apropriou das metáforas religiosas para forjar o discurso associado às questões de trabalho e da identidade docente, e como os educadores reproduziram tais ideias em discursos proferidos nas situações comemorativas (SCHEFFLER, 1974). Por outro lado, e ao mesmo tempo, existia todo um movimento no campo educacional pela modernização do ensino que significou, entre tantas demandas, a substituição dos princípios metodológicos educacionais religiosos pelos científicos. Esses contrastes permearam os textos dirigidos aos professores e publicados na época, indicando o próprio período de transição que se vivia. Ao tratar da identidade e da função social dos professores, recorria-se às metáforas religiosas, mas, na constituição dos métodos relacionados ao ensino, fundamentavam-se as teorias educacionais nos princípios científicos em projeção com o movimento da Escola Nova. Neste sentido, foi possível perceber uma clivagem dos saberes disseminados acerca da profissão docente nos manuais e periódicos educacionais em momentos de projeção social, como em discursos oficiais ou situações comemorativas ressaltavam-se as metáforas religiosas associadas à função e a identidade do professor; já em situações de trabalho escolar e de identificação dos métodos de ensino mais apropriados, escolhiamse os de base científica.

Apesar de divulgarem nos discursos que faziam parte da sua programação as metáforas religiosas, as festas no âmbito escolar prescindiram de justificativas e 
fundamentações científicas no que se refere à metodologia a ser utilizada quando de sua realização, assim como as potencialidades educativas da inclusão de tal prática no cotidiano escolar. As prescrições publicadas sobre as festas faziam parte dos saberes aprendidos nas escolas normais, como pudemos depreender da análise de materiais utilizados nestas instituições para formação dos profissionais: dentre os saberes preparatórios para a carreira docente estariam os de organização metódica de festas escolares. Lembrando que a questão do método demandava, desde a apropriação de uma linguagem própria (conhecer e interpretar os novos termos científicos utilizados), até a escolha do melhor modo de organizar cada atividade que se pretendia educativa (escolhendo a melhor ordem refletidamente seguida na atividade escolar).

Para a compreensão mais acurada sobre as discussões dos métodos a serem utilizados nas relações de ensino-aprendizagem, é preciso fazer um recuo no tempo, e percebê-las em um intricado jogo de poderes e concretizações que foram tornadas possíveis no âmbito educacional. Tais discussões foram uma constante nos discursos educacionais considerados modernos dos séculos XVIII e XIX não somente na área educacional, mas também nas questões de ensino tratadas no âmbito médico ${ }^{69} \mathrm{e}$ jurídico. Para a organização de um sistema condizente aos paradigmas modernos de ensino, era necessário que os professores seguissem métodos determinados, definidos em legislação específica e detalhados nos manuais e periódicos de ensino. O progresso esteve associado, no discurso do período, ao desenvolvimento intelectual e cultural da nação que só poderia ocorrer por meio de reformas educativas de bases científicas com objetivos de suprimir o atraso no ensino oficial (HILSDORF, 2006). Para o grupo de educadores, governantes e intelectuais, independentemente das suas posições políticas e ideológicas, as práticas modelares do ensino científico, prático e objetivo, tiveram lugar importante e deveriam inspirar-se nos países referenciados como adiantados do centronorte da Europa e dos Estados-Unidos. Os debates incidiram sobre a temática da escola como a instituição melhor organizada para garantir o desenvolvimento intelectual, moral e social dos "novos", em detrimento do ensino doméstico que, pulverizado nas diferentes famílias e preceptores, não se mostrava tão eficaz:

Para se firmar como o lugar do ensino público em contraposição ao doméstico, a escola deveria mostrar-se capaz de garantir a eficácia da

\footnotetext{
${ }^{69}$ Para uma discussão mais detalhada sobre a modernidade pedagógica presente nos discursos médicos do século XIX, ver: MORAES, Dislane Zerbinatti. A modernidade pedagógica no discurso médico do século XIX. In: Anais do III Congresso Brasileiro de História da Educação: A Educação em Perspectiva Histórica. Paraná: Pontífice Universidade Católica do Paraná: Sociedade Brasileira de História da Educação, 2004, CD-ROM. p. 1-10.
} 
sua performance, diminuindo o tempo despendido no aprendizado do ler e do escrever e minorando o sofrimento das crianças medido pelas mãos inchadas dos bolos da palmatória (HILSDORF, 2006, p. 67).

Além das dimensões pessoais e de exemplaridade dos docentes, a experiência prática fundamentada em métodos eficazes de ensino também foi constitutiva da formação docente e deveria ser objeto de atenção dos futuros educadores. Entretanto, de acordo com Pimentel Filho $(1919,1932)^{70}$, a prática sozinha poderia ter, entre outros os seguintes inconvenientes: "conduzir o ensino à rotina; dificultar a adaptação do professor a circunstâncias adversas e produzir resultados incertos e puramente individuais". Por estes motivos, a prática deveria ser, na opinião dos autores, regulada e rigorosamente induzidas pelos paradigmas da ciência. $\mathrm{O}$ professor desatento às questões do método poderia provocar, nas palavras dos educadores da época, uma desordem no "espírito dos alunos". Neste caso, as festas como práticas escolares contextualizadas e representativas do adequado funcionamento da escola e da atuação do docente deveriam seguir os procedimentos científicos que embasaram toda a discussão metodológica da modernidade pedagógica.

Uma das primeiras discussões que fundamentou a escolha dos melhores métodos pelos educadores foi construída a partir da distinção que deveria estabelecer-se entre o ensino doméstico e o ensino oficial. A instituição escolar deveria ser aquela capaz de mostrar um ensino mais eficaz e menos sofrido no aprendizado do ler e escrever, dirimindo sua imagem social de um lugar que não sabia ensinar por contrariar práticas tradicionais adeptas da representação de que o ensino "entra com o sangue" (HILSDORF, 2006). O debate organizava-se, assim, em torno de dois eixos principais: o primeiro relacionado aos castigos físicos abusivos que a escola moderna ${ }^{71}$ não poderia aceitar e, em segundo ao tempo e aos métodos escolhidos para o ensino - o melhor método era aquele capaz de garantir uma aprendizagem tranquila, em um tempo curto. ${ }^{72}$ Os debates elaborados no campo educacional foram logo tomados como bandeiras políticas dos republicanos e monarquistas que disputaram a hegemonia na área

\footnotetext{
70 Alberto Pimentel Filho (1875-1950) foi formado em Medicina e atuou como professor do ensino normal desde 1901, nas escolas de Lisboa, especialmente nas áreas das ciências físico-químicas e naturais, da pedagogia (1915-1916) e, mais tarde, de Psicologia e Pedologia (MoGARRO, 2006).

${ }^{71}$ Lê-se, escola pública, laica, democrática e estatal para todos.

72 Os textos dos compêndios e periódicos de ensino propunham a "nova e controvertida" substituição do método da soletração pelo método de leitura, largamente empregado na França, Itália, Espanha e Portugal, pelos procedimentos analíticos-sintéticos de fundamentação intuitiva e que trabalhavam o ler e o escrever, surgidos na Suíça, Alemanha, Áustria e parte dos Estados Unidos (HILSDORF, 2006).
} 
educacional por meio de argumentações sobre os melhores métodos de ensinar evidenciando nos periódicos da época (passagem do século XIX para o XX) ${ }^{73}$ (idem).

As propostas metodológicas amplamente divulgadas nos contextos educacionais do mundo ocidental como sinônimo da modernidade pedagógica previam a organização de um currículo escolar que possibilitasse a formação integral do educando. No caso paulista, a renovação do ensino aconteceria, segundo os reformadores da instrução, com base em dois pilares: a formação adequada dos novos professores e a adoção do método intuitivo em todas as escolas de educação $\operatorname{preliminar}^{74}$. A confiança, considerada muitas vezes exacerbada nos métodos, era constitutiva da mentalidade do século XIX, impregnada dos princípios de racionalização da produção e da vida social. O método era considerado o caminho seguro para alcançar metas e objetivos estabelecidos e garantir a racionalização dos sistemas educativos. Dessa forma, ao mesmo tempo em que as festas organizadas pelas escolas deveriam seguir uma técnica ou metodologia específica para garantir a sua eficácia pedagógica, também serviram de palco para as discussões acerca dos melhores métodos de ensino a serem empregados no processo educativo das crianças. Em tais ocasiões, os educadores podiam expor suas ideias nos discursos proferidos, bem como atestar concretamente, por meio dos resultados apresentados pelas crianças, o sucesso das suas práticas de ensino.

As discussões sobre métodos, modos, formas e processos de ensino estiveram presentes em quase todos os manuais estudados tanto no Brasil quanto em Portugal, e demonstraram as dificuldades que enfrentou a nascente ciência pedagógica para encontrar uma linguagem rigorosa e conceitos objetivos, assim como os apresentados

\footnotetext{
${ }^{73}$ O jornal "A província de São Paulo" (1875), por exemplo, foi reticente em colar-se no regime que apoiava, o republicano, mas, desde o início apoiou o discurso que associava o desenvolvimento social ao escolar. A escolha e a citação de autores em diversos periódicos estiveram associadas ao regime que representava; por exemplo, os métodos de Monteverde, Castilho, Abílio César Borges e Augusto Freire da Silva, apesar de serem os mais difundidos e praticados na província, quase não eram referenciados nos jornais e revistas da época, pois estavam associados ao "tempo atrasado da Monarquia" e deveriam ser substituídos por outros, mais evidenciados, como o João de Deus, Antonio Silva Jardim, João Köpke e Otaviano Hudson, categorizados como republicanos e adeptos do positivismo (HILSDORF, 2006).

${ }^{74}$ Com relação aos métodos de ensino, entendidos como a ordem refletidamente seguida na apresentação das noções, os manuais indicam a existência de dois tipos principais (LEITÃo, 1915, p. 40): o indutivo e o dedutivo, que deveriam ser utilizados de forma associada, ou seja, primeiro apresentar às crianças a indução e depois a dedução, de forma a respeitar a 'ordem natural do desenvolvimento da criança'. Além dos métodos, os modos de ensinar, compreendidos nas suas três modalidades, o modo individual, o modo mútuo e o modo simultâneo, também são recorrentes nos debates acerca das formas de distribuição dos alunos segundo o maior ou menor número deles a participar de uma lição. O predomínio do modo simultâneo ou coletivo, principalmente nos modelos de escolarização de massa constituiu um bom indicador da forma gradual como este modelo escolar foi se impondo no campo pedagógico como o mais, ou o único legítimo, de educar os alunos. Necessitava-se educar o maior número de indivíduos ao mesmo tempo e as festas potencializaram este desígnio.
} 
nas ciências da natureza, para a definição da prática pedagógica. Muitos autores não tinham bem definidos estes conceitos e não é raro perceber contradições entre as ideias dos principais educadores da época ${ }^{75}$ (BоTO, 2010). Não foi tarefa fácil definir os melhores métodos de ensino, mas foi possível identificar uma voz uníssona que afirmava a importância desses ao terem suas bases explicativas na ciência; todas as ações e eventos escolares deveriam ser meticulosamente descritos e devidamente fundamentados pelas pesquisas científicas para que tivessem alguma validade e pudessem ser veiculados nos materiais formadores de professores.

Nos manuais de ensino, as orientações sobre os melhores métodos de ensinar perpassam todas as disciplinas curriculares, sendo mais apropriadas para umas do que para outras (é mais fácil seguir o modelo de perguntas e respostas para uma aula teórica de história do que para outra de trabalhos manuais). As ocasiões festivas sintetizam estas proposições ao retomarem as últimas orientações metodológicas no seu preparo e fundamentação e se relacionarem aos ensinamentos de outras disciplinas presentes no currículo oficial, tais como canto, música, desenho, ginástica, educação física ou educação moral e cívica. Ao atenderem as diferentes disciplinas, os alunos tinham oportunidade de se prepararem para as festividades escolares, mesmo que estas fossem convocadas de forma repentina. Neste caso, fez-se necessário, a partir das orientações previstas nos manuais de ensino, retomar as principais ideias destes ensinamentos para assim relacioná-los aos propósitos da festa.

As discussões metodológicas registradas nas páginas dos manuais de ensino analisados indicaram, em diferentes momentos, as melhores formas de organizar metodicamente as comemorações escolares com o propósito de potencializar suas finalidades educativas. Em capítulos diversos daqueles manuais, as festas foram apresentadas como formas indiretas de ensino, como "meios auxiliares do ensino" (AguAYo, 1935), especialmente no ensino do civismo (TOLEDO, 1932) ou, como uma das "atividades extra-classe - passeios, excursões e recreações" (SILVA, 1957; LOUREIRO, 1950; LAGE, 1945), e ainda, como uma maneira de estabelecer relações entre "a escola e a vida social" (PlANCHARD, 1942). Os "meios auxiliares de ensino" eram definidos como os meios capazes de por em prática conteúdos teóricos e abstratos aprendidos em sala de aula, como por exemplo, o conceito de civismo que, segundo

\footnotetext{
75 Exemplo desta busca encontra-se nos manuais pedagógicos escritos por Augusto Coelho, nos quais o autor afirma a ideia de pedagogia como uma ciência que deveria ser compreendida à luz de um conjunto de leis objetivas (Вото, 2010).
} 
opinião dos educadores da época (AGUAYO, 1935 e TOLEDO, 1932), poderiam utilizar como meios auxiliares a celebração das festas patrióticas, dentre outras atividades, para o seu ensino e aprendizado. Para Toledo ${ }^{76}$ (1932), os arranjos escolares, o escotismo, as excursões, a observação da natureza, os hinos, as danças, os jogos, o desenho, o trabalho manual e os comentários a acontecimentos palpitantes da época, constituíam-se modos de objetivação atraente a tornarem efetivas "as emoções que as palavras só transitoriamente e dificilmente evocam na mente verde da infância" (p. 83-84). Nestes casos, os festejos, organizados com uma metodologia adequada poderiam ser considerados eficazes para o ensino de conteúdos do currículo oficial, a festa tornava-se o pretexto para o texto, que foi o aprendizado dos valores cívicos pelas crianças e sociedade.

Neste sentido e para atingir os fins desejados, as comemorações escolares deveriam ser organizadas "com a necessária prudência e com o devido método" (VIANA, 1946). Os pontos fundamentais a serem considerados seriam: $1^{\circ}$ ) concretização da ideia geral e nítida da festa; $2^{\circ}$ ) verificação antecipada dos elementos com os quais os docentes poderiam contar para a sua realização; $3^{\circ}$ ) organização prévia do programa, e escolha das poesias, trechos, monólogos, músicas, tudo adaptado à idade das crianças; $4^{\circ}$ ) preparação metódica e progressiva da festa junto aos alunos e pais; $5^{\circ}$ ) realização meticulosa da festa, de modo a não existir incidentes ou imprevistos; $6^{\circ}$ ) indicação prévia dos resultados pedagógicos e sociais a obter (VIANA, 1946).

Relacionadas aos meios auxiliares de ensino, as solenidades escolares também figuraram no rol dos capítulos dos manuais dedicados às atividades extraclasses, assim designadas por se efetuarem fora do ambiente formal das salas de aula e das exigências regulamentares do currículo oficial (MATTOS, 1960). Vinculadas ou não às matérias do currículo e dirigidas, preferencialmente por alunos supervisionados por professores, deveriam refletir, na medida do possível, a vida real, de maneira a aproximar mais e mais a escola da vida autêntica da sociedade. Além disso, eram percebidas como ótimas oportunidades para as manifestações vocacionais e de desenvolvimento de aptidões dos alunos (NÉRICI, 1960). Representadas pelos passeios, excursões, recreações e festas, as atividades extraclasses, quando bem organizadas e conduzidas pelos mestres, seriam capazes de oferecer "um novo filão de ricas possibilidades educativas para a juventude escolar de nossos dias, permitindo-lhe uma abordagem mais realista aos fatos do

\footnotetext{
${ }^{76}$ João Toledo foi Assistente técnico do ensino do Estado de S. Paulo.
} 
ambiente e da vida em sociedade" (MATTOS, 1960, p. 309-310), permitindo aos alunos uma compreensão mais acurada da realidade física e enriquecendo suas experiências escolares e de vida.

Levando os alunos a melhor observarem a realidade física e social e a lidarem com problemas da vida real, as atividades extraclasse enriquecem a experiência vital dos alunos, abrindo-lhes novos horizontes de conhecimento e novas perspectivas de ação. Levando-os a conceber, planejar e realizar programas bem definidos de atividade, estimulam sua inventiva e seu espírito criador, possibilitando-lhes a auto-expressão, formando atitudes sadias e ideais construtivos e desenvolvendo sua iniciativa, seu senso de responsabilidade e seu espírito de colaboração (MATTOS, 1960, p. 310).

As atividades extraclasses organizaram-se como oportunidades para prática do método intuitivo, cujas discussões sobre as suas potencialidades permearam o projeto de renovação e modernização do ensino do século XIX. O método intuitivo, elaborado na Alemanha no final do século XVIII, pela iniciativa, sobretudo de Pestalozzi, e posteriormente divulgado para outros países da Europa e da América, afirmou que a aquisição de conhecimentos decorria dos sentidos e da observação, sendo que a organização do ensino deveria prever etapas a partir das quais os saberes fossem se organizando "do particular para o geral, do conhecido para o desconhecido, do concreto para o abstrato" (SouZA, 1998, p. 159) ${ }^{77}$. No Estado de São Paulo, tais teorias educacionais ganharam enlevo no âmbito das reformas administrativas realizadas no final do século XIX, com destaque para as lições de coisas, considerada a expressão do método moderno, adotado por todos os países mais adiantados e coerente com os cânones racionais e científicos do ensino elementar (idem). Todos os envolvidos nas solenidades escolares tinham a possibilidade de observar e sentir os efeitos dos trabalhos escolares realizados.

A proposta modernizadora referente à associação entre as atividades escolares e a vida dos alunos foi ponto fundamental das reformas escolanovistas e pode ser visualizada em argumentos presentes nos manuais acerca da importância das atividades extraclasses no processo educacional, dentre as quais se incluem as festas escolares. Em linhas gerais, os objetivos das atividades extraclasses poderiam ser apresentados como,

\footnotetext{
${ }^{77} \mathrm{Na}$ Europa, o método intuitivo, que pressupunha uma abordagem na qual o ensino deveria partir do particular para o geral, do conhecido para o desconhecido, do concreto para o abstrato, difundiu-se principalmente a partir da segunda metade do século XIX, quando o movimento de renovação pedagógica e de modernização do ensino entrou em uma fase mais ativa, tornando-se nova tendência norteadora do ensino primário, particularmente. As Exposições Universais constituíram-se os principais veículos de difusão das ideias e das práticas desse movimento. (GIOLITTO, 1983 apud SOUZA, 1998).
} 
1) orientar o educando para atividades adequadas às suas peculiaridades e preferências; 2) dar sentido prático ao ensino teórico, por meio da sua aplicação através das realizações dos centros de estudos; 3) favorecer o desenvolvimento do espírito de iniciativa e senso de responsabilidade, pois todas estas atividades se realizam sob direção dos próprios alunos; 4) favorecer o senso de realidade, uma vez que estas atividades requerem planejamento e execução por parte dos alunos, à base do que é possível fazer; 5) favorecer a socialização do aluno, através das atividades em grupo e articulação com a comunidade; 6) dar oportunidade de aparecimento de líderes, porquanto estas atividades requerem alunos que agrupem e dirijam os colegas; 7) promover assistência didática a educandos que se atrasem nos estudos; 8) promover cursos de divulgação e de caráter popular, sob responsabilidade dos próprios alunos; 9) oferecer oportunidades de encontro vocacional e de discriminação de aptidões e 10) favorecer o desenvolvimento da personalidade do educando (NÉRICI, 1960).

Em seu compêndio Nérici (1960) ainda faz uma classificação das principais atividades extraclasse, dentre elas destacaram-se, as exposições escolares para todas as disciplinas, não somente no final do ano letivo, mas durante o ano letivo. Para estas situações, os professores deveriam convidar os pais dos alunos e toda a comunidade, fazendo desta oportunidade uma verdadeira seção festiva. As semanas comemorativas promovidas durante todo o ano pelos professores das diversas disciplinas, com temas referentes a vultos, acontecimentos e fatos vinculados às mesmas. Nessas, seriam promovidas palestras por alunos, professores e pais de alunos a respeito dos temas em foco, bem como seriam afixados cartazes, letreiros e gravuras, pela escola, alusivos aos mesmos. O motivo destas 'semanas comemorativas' seria dar, à escola, permanente aspecto festivo, assim como sentido mais objetivo para as suas atividades. Como exemplos, Nérici (1960) destaca:

As 'semanas comemorativas' poderiam referir-se a datas cívicas, a datas e acontecimentos referentes a cada disciplina ou a temas gerais como: A Verdade, Respeito à Velhice, Belezas da Natureza, Higiene, Amor ao próximo, Linguagem Correta, etc" (NÉRICI, 1960, p. 395396).

Infere-se a partir da análise dos manuais que as aulas não conseguiam atender à formação integral do aluno, enfatizando somente o aspecto intelectual. Por este motivo, se fizeram necessárias as atividades extraclasses a fim de garantir a expansão, expressão e participação da personalidade em desenvolvimento do educando nas atividades escolares. Eram atividades cuja participação do aluno foi imprescindível e este foi 
considerado o ponto de fundamental importância para o desenvolvimento da sua personalidade, que se traduzia na vontade de participar em tarefas responsáveis junto de seus colegas e de seus superiores. Além disso, essas atividades garantiriam o sentido funcional ao que era tratado em aula. As crianças sentiriam maior interesse em realizar atividades autênticas e que trariam a marca da responsabilidade, sendo que sua participação foi considerada a única forma capaz de integrar o educando à escola no sentido de levá-lo a querer e viver a vida escolar:

As atividades extraclasses propiciam essa possibilidade, uma vez que funcionam sob responsabilidade do educando, com base na participação em empreitadas comuns com seus colegas e professores, instituições sociais e pessoas outras da comunidade, em atividades de verdade, que podem ser apreciadas como contribuições efetivas para a vida escolar e social (idem, p. 413).

O estreitamento das relações entre as instituições sociais e a escola também se constituiu uma das possibilidades vislumbradas para a justificativa das realizações das comemorações no âmbito escolar. A escola, ao se constituir como o local privilegiado para a formação dos futuros cidadãos, concebeu as festas como ricas situações de interação com o meio social, consideradas ocasiões nas quais a sociedade poderia comprovar os benefícios das instituições de ensino como o melhor lugar para a educação dos alunos. A festa disseminava os valores da escola e da política dominante, mas também possuía uma finalidade social que era mostrar para a população o bom cumprimento das suas funções educativas ${ }^{78}$. Neste caso, possuíram como uma das suas funções principais, demonstrar os reais benefícios das instituições de ensino para a educação das crianças e sua competência para exercer tal função, contribuindo, em sentido mais amplo, para o processo de legitimação das escolas como locais privilegiados para o ensino em detrimento das casas e dos internatos.

Apesar de marcar o distanciamento que se desejava da educação doméstica, as escolas prescindiram da presença da família para a legitimação do trabalho escolar na esfera doméstica. A pregnância do discurso educativo dependia das formas pelas quais os pais compreendiam as mensagens explícitas das festas e os saberes científicos

\footnotetext{
${ }^{78}$ Cabe lembrar que a transferência das responsabilidades pela educação das crianças da família para a escola não foi um processo tranqüilo, mas marcado por muitas desconfianças, que sofreu influências das querelas entre o Estado e a Igreja, principalmente no século XIX, sobre quem deveria responsabilizar-se pela educação das crianças (JULIA, 2001). Segundo Azanha (1990-91), o aparecimento das instituições escolares exigiu a liberação parcial do esforço educativo das famílias para a escola. Este foi um processo muito complexo, que não deixou óbvio que a interpenetração máxima entre a escola e a comunidade fosse um benefício para a educação das crianças.
} 
divulgados pelos currículos. Na opinião dos educadores da época, a educação só poderia ser alcançada com o auxílio da família, considerada como um elemento imprescindível para o sucesso do ensino. Sem a cooperação da família, a instrução escolar seria sempre defeituosa, nas palavras da professora Maria Reis (Revista de Ensino, novembro de 1907):

\begin{abstract}
A escola sem o auxílio direto do lar, deixará de alcançar os fins a que se propõe. É no lar que se lançam os primeiros alicerces do caráter. Assim, pois para a missão do mestre ter mais sucesso e eficácia, si a escola quiser desempenhar-se da sua responsabilidade, tem de pedir a efetiva colaboração da família em tudo que aspira e realiza ... (Revista de Ensino, novembro de 1907, p. 105).
\end{abstract}

Autores de manuais pedagógicos e de artigos, tanto no Brasil quanto em Portugal, corroboraram ideias como as da professora Maria Reis e divulgaram, em veículos de comunicação, opiniões a favor da harmonia das relações entre a escola e a sociedade, representada, primeiramente, pelos pais dos alunos, para o bom desenvolvimento do ensino. Na opinião de Émile Planchard (1942) ${ }^{79}$, estariam nas relações estabelecidas entre a escola e a vida social o princípio fundamental de todos os programas de educação, ou seja, o de estabelecer uma dupla harmonia entre as exigências sociais e as possibilidades infantis, entre a experiência individual e os ideais sociais (PlANCHARD, 1942, p. 191), confirmando-se, assim, a associação da educação escolar com o desenvolvimento social. Desse modo, as comemorações escolares tornarse-iam férteis oportunidades a serem aproveitadas pelos mestres para estreitar suas relações com as famílias.

Assim como a escola não poderia prescindir de uma efetiva associação ao meio social no qual estivesse inserida, os professores não conseguiriam realizar um bom trabalho se ignorassem o ambiente imediato e particular que rodeia cada criança, ou seja, a família. Esta deveria ser um elemento bem conhecido e explorado pelo mestre nas suas aulas, de forma a confirmar a concepção renovada de ensino da época de que a escola foi feita para criança e não a criança para a escola (PLANCHARD, 1942). As reuniões periódicas de pais e professores, que não deveriam ser conferências de caráter acadêmico ou discussões metodológicas, mas sim situações para tratar de questões concretas da educação por meio de palestras familiares e simples, também se tornariam

\footnotetext{
79 Professor extraordinário da Universidade de Coimbra, doutor em Ciências Pedagógicas e autor do manual pedagógico A Pedagogia Escolar contemporânea - Bases - Orientações - Aspectos, publicado pela Coimbra Editora Ltda, em 1942.
} 
recurso bastante útil na aproximação da escola e família, bem como os boletins semanais publicados pelas instituições, as festas escolares, as excursões e os exercícios escolares,

(...) em que os pais podem intervir como informadores (dados profissionais, domésticos...) são outros tantos meios de estreitar o contacto entre a escola e a família, de forma a que estas trabalhem no mesmo sentido e facilitem a tarefa dos professores assegurando um maior rendimento escolar e social (PLANCHARD, 1942, p.195).

Ao viver as festividades, a criança também lançaria no seio familiar o maior interesse por elas e pelas instituições que as engendraram. Elas surgiram, dessa forma, como momentos específicos para a aproximação harmônica e profícua da escola e da sociedade, trazendo a família para a escola e demonstrando os avanços alcançados na educação de cada criança. Assim como as atividades escolares, tais eventos deveriam ser sistematizados pelos professores e se relacionarem às práticas de ensino e aos conteúdos do currículo oficial. Ela deveria ser um estímulo para o aprendizado dos alunos e não uma substituta do mesmo, bem como ser capaz de incitar o interesse do aluno e da sua família pela escola, mas não, por estes motivos, ser utilizada de forma abusiva.

Seguindo as etapas indicadas nas metodologias festivas dos manuais concretização da ideia geral da festa e organização prévia do programa, verificação antecipada dos elementos necessários à festa, preparação metódica e progressiva da festa, realização meticulosa da mesma, de modo a não haver incidentes imprevistos, definição de resultados pedagógicos e sociais a obter - os mestres poderiam garantir as vantagens da atividade festiva, tais como - aproximação da família à escola, garantia do interesse dos alunos e ensinamento de conteúdos de forma lúdica e por método ativo. Entretanto, outros cuidados deveriam ser tomados a fim de não permitir situações de crítica, vaidades desmedidas ou invejas e, até mesmo, provocar desavenças entre o mestre e as famílias das crianças não selecionadas para os números da festa (VIANA, 1946).

As prescrições acerca das realizações festivas pelos professores no âmbito escolar presentes no discurso manifesto sobre a educação, indicaram todo o cuidado que se deveria ter com esta atividade quando transportada da esfera pública para a escolar. Neste movimento de transposição, a técnica festiva deveria adequar-se a todas as exigências metodológicas, científicas, pedagógicas e educacionais desse novo meio. Ora 
indicadas como meios auxiliares de ensino e capazes de melhorarem a aprendizagem e, em alguns casos, até os comportamentos dos alunos, ora para promover a união e a harmonia entre a escola e o meio social, ou ainda, como atividade extraclasse lúdica para o descanso dos alunos, as comemorações escolares exigiram saberes e fazeres profissionais docentes que alteraram significativamente o trabalho escolar. Os ensaios, as relações a serem estabelecidas entre os conteúdos curriculares e os elementos específicos dos programas das festas, tais como as homenagens, as manifestações artísticas (canto, teatro, ginástica) e as intelectuais (exames e premiações); a disseminação de valores e comportamentos adequados socialmente; as formas de ser e de se apresentar na profissão docente e o papel social da educação; as metodologias de ensino e os seus resultados mais ou menos eficazes e as etapas da preparação das festas foram novidades que, direcionadas e relacionadas aos professores e suas práticas, alteraram o modo como os professores percebiam as representações acerca de si e da sua profissão, bem como as formas de estar e de se aprender nas instituições escolares. O tempo da festa era o tempo de aprender, no qual todos seus componentes deveriam estar preparados para que os alunos tirassem o máximo proveito educativo dessas atividades.

\section{3-2 - As festas antipedagógicas: as dissonâncias nos discursos dos educadores da época}

Para além das prescrições existentes nos manuais de ensino e nos periódicos educacionais, que na maior parte dos textos assinalaram com veemência e em tom laudatório o caráter pedagógico das festas, foi preciso retomar algumas práticas, que associadas ao trabalho docente nos permitiram conhecer os modos pelos quais a instituição escolar transformou e produziu sentidos próprios ao que foi estabelecido externamente (JULIA, 2001). Os textos veiculados nos periódicos de ensino eram escritos e publicados com objetivos que muitas vezes enalteciam os eventos, mostravam suas qualidades e importância para a constituição de um sistema público de ensino, seja quando inseriam estas notícias no âmbito das grandes realizações estatais e públicas para a população, seja quando da escolha do gênero narrativo, das palavras, do que deveria ser comentado ou não, o autor criava uma determinada imagem de escola, representação de instituição de ensino e da data comemorativa (CHARTIER, 1990). 
Os textos utilizados para compor a história das festas escolares foram entendidos como narrativas organizadas por um autor (indivíduo) com um determinado objetivo. Neste sentido, se em um primeiro momento a análise dos conteúdos dos mesmos foi suficiente para o estabelecimento de uma tipologia das festas no período de consolidação da república brasileira, posteriormente se fez relevante nos demorarmos sobre os textos que traziam estas notícias, entendendo-os como escritos que organizados de formas específicas buscaram instigar determinadas percepções e sentimentos sobre as festas, representações, pontos de vistas específicos e disputas em torno de saberes e práticas festivas (MORAES, 2006). O documento elaborado por um autor em um determinado contexto histórico e social representa uma reconstrução criativa acerca da realidade que vivenciou e selecionou para seus registros, sendo que isto, segundo Sevcenko (1983) não pode ser desconsiderado no trabalho do historiador. As notícias festivas possibilitaram conhecer além dos acontecimentos históricos desconsiderados pela história dita "oficial", as influências desses acontecimentos nas produções da imprensa educacional, bem como as características do local social ocupado pelo escritor que produziu esse tipo de texto e seu veículo de divulgação.

A transformação dos objetivos e finalidades das comemorações implicou também uma modificação dos sentidos atribuídos pelos idealizadores das festas e pelos participantes das mesmas aos eventos festivos. Em diferentes contextos, as festas em geral e as festas escolares possuíram distintos sentidos ${ }^{80}$, e alguns destes puderam ser apreendidos no desenvolvimento desta investigação. Se em um primeiro momento as festas foram valorizadas enquanto artifício para a confirmação dos avanços do governo no campo educacional, para a apresentação da escola enquanto instituição mais preparada para o ensino das crianças, para a divulgação de uma imagem de professor e de alunos e de apresentação dos melhores métodos de ensino, após alguns anos de implantação do sistema de ensino, sua potencialidade passa a ser contestada no cenário brasileiro e ela passou a ser concebida até como uma das causas perturbadoras do

${ }^{80}$ O termo sentido é apresentado aqui de acordo com a concepção discutida por Silva (2004) na sua pesquisa histórica acerca dos sentidos atribuídos à profissão docente pelos próprios professores. Para o estudo desta questão, a autora utilizou-se dos testemunhos deixados ou concedidos por professores e professoras com larga atuação no ensino primário e na legislação que organizou os sistemas de ensino público em Santa Catarina, São Paulo e Portugal. De acordo com Silva (2004), os sentidos não são dados a priori, mas são construídos numa base cultural, num conjunto de valores e representações, em situações de interação e relação. No caso das festas escolares, eles foram tratados tomando como referência as discussões efetuadas pelos educadores da época acerca da validade ou não desta prática no âmbito escolar e nas próprias publicações do período, que em distintos momentos deram mais visibilidade a um tipo de evento comemorativo em detrimento dos outros. 
ensino, sem nenhuma utilidade para o fim da educação. Uma das primeiras críticas às festas escolares foi publicada na Revista de Ensino, em 1908, em artigo assinado por João Beckmaun. Naquela oportunidade, o autor argumentou que as festas escolares já haviam cumprido a sua função, que era a de tornar bem explícito o desenvolvimento das primeiras escolas republicanas e, que naquele momento já existiriam alguns exageros nessas festas:

temos assistido a verdadeiras exibições teatrais, incompatíveis com a natureza essencialmente prática e educativa dos estabelecimentos de ensino, o que não deixa de revelar perda de tempo, que podia ser empregado em coisas mais úteis (Revista de Ensino, 1908, p. 36).

As festas deveriam ser, para o autor, uma repetição bem organizada e bem selecionada de aulas dadas durante o ano letivo, conforme já era realizado em algumas escolas e não "grandes exibições teatrais". Deveriam, assim, trocar os hábitos dos festejos pelos que estavam se iniciando nas escolas, como os de comemorar as datas nacionais, como a Festa da Bandeira, através de "festas íntimas, como as aulas cívicas, sem pompas, nem aparatos" (Revista de Ensino, 1908, p. 36, p. 36). Na esteira das críticas publicadas, Guilherme Kuhlmann (1919), por exemplo, assinalava que as festas nacionais traziam um "minguado ensino cívico (...) poucos resultados, só vésperas dos feriados ouvem falar da data, festas", mas o ensino cívico "deve ser principal preocupação, em todas as aulas" já que é distribuída nos anos do curso primário e tem lugar determinado no horário (Revista de Ensino, ano 17, jun-dez/1918 - publicado em out/1919, p. 15). Os inspetores de ensino também se manifestaram sobre o tema e corroboraram as opiniões dos professores citados acerca das comemorações escolares, apresentando-as como uma das causas perturbadoras do ensino, segundo o inspetor de ensino Miguel Carneiro Junior (1908-1909):

\section{Festas Escolares}

Uma outra causa perturbadora do ensino, são as festas de caráter mais ou menos teatral, com que muitos grupos escolares e algumas escolas isoladas encerram os trabalhos do ano letivo.

Essas festas, de valor educativo muitíssimo contestável, perturbam extraordinariamente o ensino, por causa dos ensaios que exigem.

As crianças, no entusiasmo das festas em preparo, esquecem os preceitos disciplinares, abandonam os estudos e adquirem o hábito pernicioso da vadiagem.

A escola deve ser alegre, deve ser festiva, para que a criança se sinta bem nela, mas, por certo, não será com a interpretação de comédias e revistas que tal intuito se conseguirá (Anuário do Ensino do Estado de São Paulo, 1908-1909, p. 72). 
Pelo que se percebe, parte das críticas às festas se devia ao fato dessas ocuparem muito tempo com as preparações para não surtir o efeito desejado. Além disso, por serem comemoradas no dia do feriado não contentavam os professores que perdiam o dia de descanso. Talvez tenha sido esse um dos motivos pelos quais alguns festejos acontecerem em algumas escolas na véspera do dia indicado, como ficou indicado no texto do inspetor Aristides de Macedo (1910-1911) que reclamava que: "as comemorações cívicas deveriam ser realizadas na data correta e não na véspera como costumava acontecer", já que para o inspetor "essas constituíam uma ótima oportunidade para a educação moral e cívica e para a formação do patriotismo na criança” (Anuário do Ensino do Estado de São Paulo, 1910-1911, p. 100-107). Por outro lado, noticia-se na Revista Escolar que a festa de 15 de novembro, "esta grande festa nacional foi brilhantemente comemorada em todos os nossos estabelecimentos de ensino [...]. O dia seguinte, segunda-feira, foi feriado nas escolas para descanso de alunos e professores" (Revista Escolar, n. 12, ano 1, 01/12/1925, p. 101). Pelo fato dessa notícia datar da década de 1920, pode ser que alguns anos após a instituição das festas, as reivindicações dos mestres tivessem sido acolhidas e o descanso garantido após as celebrações.

Os romances autobiográficos dos educadores da época constituem-se material profícuo para a nossa análise ${ }^{81}$, já que nos apresentam as impressões e reflexões dos professores sobre essa prática. Para este trabalho foram escolhidos três títulos: o romance intitulado O calvário de uma professora (1927), escrito por Dora Lice, que remonta aos anos finais do século XIX e iniciais do século XX, período ao qual são dedicadas as reflexões que aqui se apresentam. O livro de Raimundo Pastor, Alegrias, agruras e tristezas de um professor. Recordações de Xiririca, Itanhaém, Iporanga e Vila Bela de 11-07-1919 a 5-1926 e, por fim, O professor Jeremias (1921) escrito por Léo $\mathrm{Vaz}^{82}$.

Hermengarda, protagonista do livro $\mathrm{O}$ calvário de uma professora, ao relatar as festas, o faz de forma pouco entusiasmada afirmando que essas constituíam verdadeiro suplício para os alunos e professores. Nas palavras da autora, "as obrigatórias e tão repetidas comemorações cívicas, como são geralmente feitas,

\footnotetext{
${ }^{81}$ Para um estudo mais detalhado sobre os romances autobiográficos e a importância da autobiografia para a formação e autoformação de professores, ver respectivamente: MORAES (1996) e CATANI \& VICENTINI (2006).

${ }^{82}$ O estudo destes romances foi realizado por MORAES (1996) em sua dissertação de Mestrado, intitulada: Literatura, memória e ação política: uma análise de romances escritos por professores paulistas.
} 
constituem verdadeiro suplício, tanto para as professoras como para os alunos" (DoRA LiCE, 1927, p.72), causam prejuízo às classes pelos múltiplos ensaios, além de tirar do mestre o descanso que lhe proporcionaria o feriado concedido por lei. Para ela, "É preferível ao professor, dar aula o dia todo, a ficar de pé, horas a fio, sob um sol abrasador, ouvindo recitar as poesias sempre repetidas dos nossos grupos escolares" (DORA LICE, 1927, p.72). E por fim justifica,

quando não lhe era permitido fazer na véspera a comemoração tomava o diretor a si, o encargo dos ensaios, e no dia consagrado os professores eram assistentes apenas. Assim não se prejudicava o ensino nem se cansavam os professores já bastante sobrecarregados com aulas diárias. (DORA LICE, 1927, p.72).

Por outro lado, existiam professores tão entusiasmados com as festas, que até propunham a comemoração de outras datas e temas, esse é o caso, por exemplo, do amigo do protagonista Jeremias do livro O professor Jeremias (1921), Claudino José Maria, que propõe a festa das formigas. Esse relato é feito em um capítulo no qual o autor transcreve uma carta recebida de um amigo mestre por ocasião da Festa da Árvore, "que ultimamente se realizou em todo o Estado, com a pompa e o proveito habituais" (VAZ, 1921, p.205). Nesta carta, o amigo Claudino José Maria descreve e comenta a última festa da árvore realizada no Estado de São Paulo. Cabe destacar deste excerto a importância dada à celebração pelo professor, que na ocasião se colocou como inventor e propõe mais outras festas. Entretanto, tal entusiasmo poderia também ser percebido como uma ironia, o que não fica claro na narrativa:

Como meu colega, deves ter passado pelo gosto de participar da última festa que anualmente dedicam os poderes públicos aos nossos irmãos vegetais. Eu também passei por ele. Tive mesmo como bom professor, que me prezo, um soneto encomiástico ao cipó...

(...)

Mas, como te dizia, tive também o gosto, como tu. O que, entretanto, tive a mais, foi certa idéia, que ora submeto a sua apreciação.

Tive-a durante a festa.

(...) mirava eu, distraído, o chão do pátio, quando os meus olhos caíram sobre um cordão verde de folhas de roseira, lépido e ondulante, que se insinuava e sumia numa talisca do muro próximo.

Não adivinhar o que era?

Eram formigas, meu caro, distintas formigas lafontaineanas, na faina de enceleirar, para as futuras zumbaias às cigarras vagabundas.

'Fiat Lux'

E a luz se fez no meu cérebro, sob a forma da idéia que te anunciei. E eu também vi que a luz era boa. Tão boa que eu t'a envio para que me digas se não é aproveitável sob o ponto de vista educativo e moralista. (...) A idéia é a da instituição da FESTA DAS FORMIGAS (VAZ, 1921, p. 206-207). 
A existência de professores que desejaram multiplicar as festas não se fez na ausência de alunos que desejaram eximir tais comemorações como forma mesmo de punir os dirigentes e contestar os rituais escolares. Esse é o caso, por exemplo, da situação narrada por Léo Vaz no seu romance O Professor Jeremias, na qual os alunos decidiram na véspera da festa de formatura cancelar os festejos como forma de punir o diretor Conrado, que se fez ser convidado como paraninfo da formatura. Os alunos decidiram receber os diplomas na secretaria da escola, sem nenhuma recepção festiva. Segundo os alunos, o diretor ao se convidar paraninfo havia retirado a "espontaneidade das festas". Para eles:

Em vista das circunstâncias supervenientes, que lhes tiraram a faculdade de manifestar com sinceridade a sua alegria pela feliz conclusão dos seus labores escolares, os professorandos deste ano, em reunião solene ontem efetuada, resolveram prescindir dos habituais festejos com que anualmente são distribuídos na Escola Normal os diplomas dos alunos que terminaram o respectivo curso.

A recepção dos diplomas será feita, simplesmente, sem nenhuma solenidade, na secretaria da Escola ao último dia letivo do ano corrente (VAZ, 1921, p.106).

Entretanto, o Professor Conrado não admitiu tal situação e andou de porta em porta convencendo os pais a incitarem seus filhos a participarem das festas "a torná-los festivos e festeiros conforme convinha ao bom nome da escola e ao sucesso da carreira dos futuros mestres”. O governo, conforme dizia Conrado, não verá com bons olhos "uma turma de moços insubmissos, que se despede da Escola numa atitude oposicionista e demagógica. Tais moços nunca seriam bons funcionários: o governo os repelirá. E o governo é sempre o governo!...” (VAZ, 1921, p.108). E a festa aconteceu, a despeito das reivindicações estudantis, com todas as pompas e aparatos possíveis. A narração desse evento indica o potencial propagandístico das festas, ao se fazer convidar como paraninfo da celebração, o diretor da escolar desejou mostrar não somente o quanto era querido (ou não) entre os alunos, mas também como a "sua" instituição de ensino contribuía para a formação dos cidadãos.

As descrições, as impressões e as interpretações dos educadores da época sobre as festas escolares expressas nos depoimentos, romances, discursos, artigos publicados no período, permitiram perceber os diferentes sentidos e apropriações desses eventos festivos, que não poderiam ser percebidos em outros textos, como por exemplo, as interpretações elaboradas por estudiosos contemporâneos. Desse modo, este material mostrou-se profícuo para a compreensão de uma visão interna das festas, ou seja, das 
formas pelas quais os professores concebiam a comemoração escolar como um aspecto da cultura escolar e se apropriavam de seu significado.

As mensagens publicadas acerca das celebrações escolares permitiam ao leitor conhecer a festa que o autor gostaria que fosse conhecida, sua percepção e ideia do acontecimento festivo. É a escolha de uma, dentre tantas, representações que se poderia ter da solenidade. Neste caso, constitui tarefa do historiador explorar sistematicamente essas fontes, considerando não só a mensagem em si, mas as formas pelas quais ela foi fabricada e confrontando-as com outras fontes históricas. A ênfase em um ou outro aspecto indicará o objetivo a ser alcançado pela mensagem. Percebe-se que nas narrativas veiculadas sobre as festas escolares combinaram-se duas funções: a expressiva/emotiva (destaque para as emoções e sentimentos do autor) e exortativa (ênfase na compreensão adequada do evento pelo leitor).

Para além da tipologia estabelecida, faz-se relevante assinalar os efeitos que determinadas disposições de textos almejavam alcançar, percebe-se que cada tipo de narrativa permite uma representação distinta da festa escolar. No caso das pesquisas históricas educacionais, cabe retomar que qualquer ordenação de um discurso deve ser considerada e que em todo discurso sempre existem dois níveis: o das significações que o historiador voluntariamente atribui às narrações e descrições, dos quais se pode tirar de forma explícita lições de moral ou políticas, e um segundo nível cujas significações são perceptíveis por meio da temática do historiador ou da própria estrutura da narrativa que revela, mesmo que implicitamente, uma determinada visão e filosofia da história (BARTHES, 2004). 


\title{
Capítulo 4: A máquina festiva a serviço das escolas brasileiras e portuguesas: os seus diferentes tipos, usos e funções
}

\begin{abstract}
As revoluções têm que lidar ao mesmo tempo com a organização de uma nova vida social e política e com a construção de um imaginário capaz de recuperar um equilíbrio perdido ao longo do tempo. Assim, ao se iniciar um momento novo, precisa-se evocar um tempo remoto. Lá estariam as raízes, o sentido verdadeiro do homem e da sociedade. Esta ubiqüidade das revoluções, marcadas por ter um pé no futuro e outro no passado, tem se delineado de diferentes maneiras (OLIVEIRA, 1989, p.173).
\end{abstract}

Ao longo de sua história a humanidade festejou: em diferentes ocasiões, para diferentes fins e de formas díspares. Ora relacionadas aos condicionantes naturais (mudanças de estações ou estágios de plantios e colheitas), ora associadas aos ritos sociais (casamentos, mortes, aniversários e iniciações), elas tiveram significados ímpares que mereceram investigações de sociólogos, antropólogos, historiadores e etnógrafos. Percorrendo caminhos de distintos campos de pesquisa, foi possível aquilatar de forma mais elaborada o objeto festa, que comparado a uma máquina, manteve engrenagens comuns e permanentes e mudanças nos seus usos. Aos conhecimentos associados à "montagem da máquina", somaram-se outros, relacionados aos objetivos dos diferentes tipos de comemorações e aos seus empregos e funções sociais, políticas e educacionais, que também deveriam ser conhecidos dos professores, pais e alunos.

Ao serem transportadas para o âmbito escola, a máquina festiva ganhou novos contornos e engrenagens mais sofisticadas, características específicas associadas aos saberes e fazeres discentes e docentes organizados em um conjunto diversificado de solenidades a serem realizadas durante todo o ano letivo. Às justificativas teóricas que fundamentaram a inserção deste dispositivo como uma atividade educativa, somaram-se as orientações práticas sobre os tipos de festas a serem inseridas nos calendários cívicos e escolares. O intuito deste capítulo é apresentar e discutir os diferentes tipos e funções atribuídas às festas realizadas nos contextos educacionais brasileiros e portugueses a partir das fontes históricas assinaladas anteriormente. Busca-se identificar aproximações e distanciamentos entre as formas de se comemorar nas escolas públicas primárias desses dois países, indicando, como a metáfora da "festa máquina" utilizada nesta tese, apresentou elementos semelhantes mais diretamente relacionados aos rituais festivos e 
que as agruparam em manifestações coletivas e conhecidas do povo, além de outros específicos aos países associados aos temas relevantes da histórica de cada um, como foi o caso das datas históricas selecionadas para figurarem nos calendários escolares.

Estabelecidas em uma estrutura semelhante, foi possível assinalar diferenças quanto aos tipos e funções atribuídas a essas, que ora se assemelharam nos dois países investigados, como foi o caso das festas que celebraram o civismo e a natureza, por exemplo, ora se distanciaram, tornando-se realidade em um dos países somente, como foram os casos das solenidades beneficentes em Portugal e as inúmeras comemorações realizadas no ano de 1922, com intenção de solenizar os cem anos da data que tornou o Brasil independente. Trata-se de um esforço para aquilatar as aproximações e distanciamentos entres as comemorações escolares destes dois países em um contexto histórico caracterizado mundialmente pela difusão de um modelo moderno de ensino.

As diferenças serão analisadas dentro dos subtítulos que organizam as comemorações em tipologias que agrupam manifestações festivas com características semelhantes, tais como as que celebraram o civismo, as instituições de ensino e a natureza e no âmbito destas, outras mais. As questões que perseguimos neste capítulo são: quais foram os festejos escolares recorrentes nos dois países? Quais eram os elementos que as aproximaram funcionalmente ou nas suas estruturas, e aqueles que as diferenciaram? Com qual intuito se celebrou nas escolas brasileiras e portuguesas? Quais são as categorias analíticas que podem ser construídas para o tratamento da temática "festas"? Pressupõe-se que dentro de uma mesma maquinaria existiram aspectos comuns e específicos que as fizeram um elemento importante das culturas escolares brasileira e portuguesa. Ao construir as categorias analíticas, retomamos a argumentação de Durkheim (1996) acerca da proficuidade do uso do termo "categorias", ao tratar das questões religiosas e manter concepções essenciais que, em um projeto social mais amplo, permitem a concordância entre as inteligências e, por consequência, a organização de toda a vida comum. As categorias são "coisas sociais"; elas "não apenas vêm da sociedade, como as próprias coisas que exprimem são sociais (...)” (p. 489), estendendo-se à realidade inteira que, ao dominar e envolver todos os outros conceitos, constitui-se em "marcos permanentes da vida mental" (DURKHEIM, 1996, p. 489). 


\section{1 - 0 Civismo - do aprendizado social ao escolar: as festas cívicas nas escolas primárias brasileiras e portuguesas}

Em diferentes contextos sociais e políticos, as festas foram utilizadas com a função de demarcar um novo tempo e uma nova organização social e política que se pretendia instaurar, como forma de recuperar o equilíbrio social ameaçado, construiu, junto à população em geral, um novo imaginário que, assim como indicou Oliveira (1989), deveria ter "com um pé no futuro e outro no passado". Neste sentido, a memória histórica pode ser compreendida como âncora e plataforma. Âncora porque garante segurança em momentos de mudança e turbilhão, e plataforma, pois permite que nos lancemos para o futuro com "os pés solidamente plantados no passado criado, recriado ou inventado como tradição" (LOVISOLO, 1989, p.17).

Sob estas funções de recriar um tempo novo e construir um imaginário social condizente às mudanças políticas e sociais localizaram-se, neste estudo, as comemorações cívicas realizadas pelas escolas primárias brasileiras e portuguesas que, organizadas em um programa bastante semelhante às demais festas, diferenciavam-se destas pelos motes selecionados e pelas funções políticas e sociais que as permearam. Celebradas em sociedades distintas, ainda é possível perceber, nessas manifestações, esforços semelhantes para a constituição de um ideal de nação e de cultura homogênea por meio dos rituais e simbolismos cívicos.

O civismo assumia, para os reformadores do período, a função antes atribuída as manifestações religiosas, ou seja, a de manter a coesão social e organizar estruturalmente a vida das comunidades. Neste sentido, são bastante férteis as elaborações de Rousseau acerca do termo religião cívica, que assumiu daquele contexto em diante o papel religador das sociabilidades desempenhado até a época moderna pela Igreja Católica, seus cultos e rituais cíclicos (Natal, Quaresma, Pentecostes, e aniversários dos santos) (CATROGA, 2004 ${ }^{83}$; DURKHEIM, 1996). A ideia recorrente foi a de que, assim como as outras religiões, o civismo, compreendido em uma série de cultos e rituais que o relacionaria ao âmbito religioso, também teria como função, normatizar a moral social. Na então denominada religião cívica, os símbolos, ritos e heróis deveriam ser outros, que não mais os indicados e selecionados pela religião católica, assim como os fundamentos transcendentes das explicações do mundo e da vida elaborados e

\footnotetext{
${ }^{83}$ A recuperação das ideias de Rousseau foi feita por Catroga (2005) especialmente a partir do escrito Do Contrato Social, do primeiro autor, publicado no ano de 1762.
} 
disseminados pela fé, tornar-se-iam objeto de críticas nos discursos que defendiam essa mesma religião. A partir deste momento, iniciou-se o que foi denominado de processo irreversível "da inevitável dessacralização, ou o desencantamento do mundo, com a possibilidade de redenção terrena da humanidade" (CATROGA, 2005, p. 10). Caberia à religião católica garantir novas justificativas para a sua permanência e criar modos de coabitar imaginários ao lado do civismo.

Apesar das críticas, é relevante destacar que os discursos e práticas que pretenderam a secularização dos fundamentos, funções e finalidades da política moderna também trouxeram consigo certo elemento de sacralidade, ainda que as suas justificativas teóricas não o admitissem. Basta atentar, nas palavras de Catroga (2005), às estratégias de inclusão afetiva que os novos poderes políticos fomentaram, para se perceber que a reprodução da moderna racionalidade política transportou consigo certas formas de sacralidade fundada em princípios e ritos que pretendiam forjar um novo ser humano, o indivíduo-cidadão. Ao mesmo tempo em que a religião cívica recuperou alguns dos princípios e ritos já conhecidos e instituídos junto à população em geral, ela alterou outros, com o objetivo de formar um novo indivíduo cuja consciência do dever não estivesse mais pautada nos ideais religiosos, mas na racionalidade.

Rousseau (1762), ao dedicar-se às explicações sobre as organizações sociais e os seus laços religiosos, elaborou dois termos para designar a relação que ainda permanecia entre a religião cristã e a religião do Estado - a religião do homem e a religião do cidadão, respectivamente. A primeira era considerada o passo inicial do indivíduo no processo de desvinculação do cristianismo e de sua libertação dogmática; a partir dela, o homem se perceberia como o único responsável por si e por seu destino, devendo seguir sua vida de acordo com a sua consciência e regras sociais. A religião do homem não implicava a existência de templos, altares, ritos, mas "cingia-se a uma adesão puramente interior a Deus e aos deveres eternos da moral, intuídos a partir da consciência, criação divina por excelência" (CATROGA, 2005, p. 13). Completava-se em uma ética, inferida a partir da essencialidade da natureza humana, uma base que daria às suas normas um valor universal. A religião do homem coincidia essencialmente com a lição dos Evangelhos, mas não com a religião do padre, o que permitiu maior autonomia e liberdade aos homens nas escolhas das suas ações.

A religião do cidadão, cujas características da sua formulação foram engendradas pelas nações, no decorrer do século XIX, servia à coesão política e social da população de um país, com objetivos mais ambiciosos foi a mais abertamente 
utilizada nas justificativas governamentais para a legitimação do seu poder. Ela indicou, contra o universalismo da religião do homem, a religação de um determinado povo à sua pátria; sendo assim, seus dogmas seriam diretamente ditados pelo Estado tendo em vista socializar o respeito pela instância política, consubstanciado no contrato social e pela lei civil dele provinda (CATROGA, 2005). O Estado tomaria o lugar de Deus na tarefa da redenção humana e da organização social, e todas as referências de organização política e social provinham dele. Era preciso solidificar a permanente renovação do contrato social, mediante a formação do sentimento coletivo e da razão, que só desempenhariam uma função social válida se os indivíduos reconhecessem, afetivamente, as regras que davam corpo a vontade geral, e as praticassem como amor do dever em todas as instituições sociais e, especialmente, nas escolas.

Ainda existiu, nas formulações de Rousseau (1762), a religião civil, composta pelas duas primeiras, que tinha como função inocular os valores morais, determinados socialmente, e produzir a civilidade mediante a sintetização de elementos das duas outras atitudes religiosas - a religião do homem e a religião do cidadão. Assim como a religião do cidadão, a religião civil também deveria contribuir para a socialização e enfatizar a interiorização do dever cívico e do patriotismo em cada cidadão, com a diferença de utilizar para isso uma série de artefatos, uns menos lúdicos, outros mais e, dentre estes, constaram as festas cívicas:

Sendo a religião civil justificada, não pela sua maior ou menor verdade, mas pelas consequiências sociais e patrióticas que provocava, compreende-se que a propugnada interiorização dos deveres sociais se materializasse numa paidéia, e que esta desse relevo à dimensão lúdica, ou melhor, à celebração de festas cívicas, em espaço público (CATROGA, 2005, p. 18).

A prática revivificadora na religião civil se realizaria não em templos, com orações ou altares, mas em ensinamentos disseminados pela escola, não somente nos diferentes momentos do processo de escolarização e na divulgação dos símbolos dessa nova religião, mas ainda, e de forma mais evidente, nas festas cívicas e no seu conjunto de elementos capazes de engendrar a cidadania. Concebida como manifestação espontânea, deveria ter como atores os seus próprios espectadores, isto é, o povo reunido e em confraternização ao ar livre e em jornadas revivificadoras do elo social (CATRogA, 2005). As situações de reuniões coletivas apareceram como as mais propícias ao ensinamento e aprendizado do civismo por toda a população. A partir das concepções elaboradas por Rousseau (1762) sobre a religião do homem e a religião do 
cidadão foi possível perceber o papel de destaque atribuído às festas cívicas como a possibilidade de constituição de uma religião civil:

Toda festa mesmo quando puramente laica em suas origens, tem certas características de cerimônia religiosa, pois, em todos os casos ela tem por efeito aproximar os indivíduos, colocar em movimento as massas e suscitar assim um estado de efervescência, às vezes mesmo de delírio, que não é desprovido de parentesco com o estado religioso. Pode-se observar, também, tanto num caso como no outro, as mesmas manifestações: gritos, cantos, música, movimentos violentos, danças, procura de excitantes que elevem o nível vital etc (DURKHEIM, 1996, p. 447).

As comemorações cívicas, concebidas na sua vertente litúrgica, foram organizadas com o fim de substituir as formas e funções do ritualismo religioso; a exaltação do passado, que os 'grandes homens' encarnavam, tornou-se instrumento fundamental, assim como a historiografia, para a produção e reprodução de uma nova memória nacional a ser relembrada de acordo com um autêntico calendário civil e escolar e não mais as datas do calendário católico. Ao voltarem-se ao passado, recuperando heróis e acontecimentos marcantes, as instituições escolares realizaram um movimento semelhante aos efetivados pelos povos considerados primitivos em rituais que ao restaurarem suas memórias e festejarem-nas em situações específicas desejaram manter e perpetuar a coesão identitária do seu grupo. Neste sentido, as manifestações de características ritualísticas, cultivadas na modernidade, buscaram criar diferentes representações simbólicas capazes de mobilizar o povo para que, em certas ocasiões, como nas festas, pudessem receber lições vivas de história (CATROGA, 2005). Ao mesmo tempo, assim como aconteciam nas outras religiões, as comemorações cívicas possuíram como função mítica, atenuar o sofrimento do trabalho cotidiano diário e a angústia inerentes à condição humana ${ }^{84}$, oferecendo proteção contra as ameaças sociais por meio da união social demonstrada nessas situações e auxiliando na compreensão do mundo, favorecendo a identificação com a comunidade e inspirando sentimentos de devoção a uma causa (DURKHEIM, 1996) que, neste contexto, era a da nação.

No rito cívico moderno, as festas-instituintes do Estado Nação se transformaram em festas movidas por interesses políticos a fim de reforçar os laços sociais e afetividades coletivas. O conceito recuperado de Mona Ozouf (1976) para tratar das primeiras manifestações festivas após a Revolução Francesa com o objetivo

84 A Igreja, a leitura, as festas religiosas ou as associadas à natureza (plantios e colheitas) destacam-se pelo convívio dos sujeitos e a instauração do coletivo. O ritmo da vida acompanhava o ciclo das festas, fossem elas profanas ou religiosas. Estas permitiam um descanso do trabalho cotidiano e a catarse das dificuldades vividas, mesmo que esses não fossem o seu propósito (LOPES JUNIOR, 1999). 
de manter vivos seus ideais, perdeu sua espontaneidade inicial adquirindo novas intenções e a celebração de explicações históricas empenhadas em legitimar e em revivificar uma dada ordem social. Os ritos cívicos engendraram um "suplemento simbólico capaz de levar as consciências a interiorizarem, como imperativos éticocívicos, os direitos e os deveres para com a sociedade" (OzOUF, 1976; CATroGA, 2005, p. 92).

As religiões cívicas tiveram como objetivo retomar o caráter integrador e socializador das outras religiões, disseminando a crença em uma promessa de salvação terrena, sacralizando entidades como a pátria e a humanidade ${ }^{85}$, realizando cultos e rituais sob a temática do civismo e concretizando o papel religador do homem à Pátria e não mais a Deus ${ }^{86}$. O civismo tomou para si nas suas elaborações originárias elementos rituais e cultuais utilizados pela religião, mas não pode ser considerado como tal já que suas funções e temáticas diferiram das originalmente propostas por estes rituais.

O civismo, retomado pelas correntes políticas e ideológicas republicanas brasileira e portuguesa, tornou-se um dos instrumentos clássicos de legitimação dos regimes políticos nos dois países e justificativa racional para a organização do poder. A escolha de uma ideologia representativa de um novo regime é sempre um acontecimento marcado por tensões e conflitos vivenciados pelos vários segmentos que disputam o $\operatorname{poder}^{87}$. Verdadeiras batalhas ideológicas e políticas que vinham acompanhadas e compostas das não menos importantes batalhas de símbolos e alegorias. Tratava-se de uma luta em torno da imagem do novo regime, cujo propósito era atingir o imaginário popular para recriá-lo dentro dos valores republicanos.

\footnotetext{
${ }^{85}$ Ou como desejaria A. Comte (s.d), a religião positivista ou da humanidade.

${ }^{86}$ Contemporâneo de J. J. Rousseau, Condorcet (2008), articulador do principal plano de instrução pública da Revolução Francesa, criticou duramente o uso que se fazia do termo religião associado ao civismo ou ao governo republicano. Para Condorcet, o caráter laico do ensino público não deveria ser entendido apenas como independência em relação às religiões, mas também com relação aos poderes públicos constituídos, não seria possível em um modelo de instrução publica para todos a substituição do catecismo religioso pelo catecismo republicano, como desejavam alguns, já que um ou outro possuía como efeito principal obscurecer a razão; os poderes públicos deveriam sim garantir uma instrução para todos, mas não relacionada a determinadas propagandas políticas. "... para Condorcet, o processo de produção e de difusão de conhecimentos, desde a escola elementar até as sociedades científicas, precisa ser independente de qualquer interferência externa de natureza religiosa, política ou "ideológica"" (CONDORCET, 2008, p. 11-12). Entretanto, tal desvinculação ideológica proposta para a área educacional não foram observadas no Brasil nem em Portugal, que tiveram seus projetos de construção de um sistema público e estatal de ensino vinculado à bandeira do governo republicano.

87 No caso brasileiro, José Murilo de Carvalho (1990) analisa a existência de três correntes que disputaram a definição da natureza do novo regime: 1) o liberalismo à americana, 2) o jacobinismo à francesa, e o 3) positivismo. "As três correntes debateram-se intensamente nos anos iniciais da República, até a vitória da primeira delas, por volta da virada do século" (CARVALHO, 1990, p.9).
} 
A elaboração de um imaginário é parte integrante da legitimação de qualquer regime político. É por meio do imaginário que se podem atingir não só a cabeça, mas, de modo especial, o coração, isto é, as aspirações, os medos e as esperanças de um povo. É nele que as sociedades definem suas identidades e objetivos, definem seus inimigos, organizam seu passado, presente e futuro. O imaginário social é constituído e se expressa por ideologias e utopias, sem dúvida, mas também - (...) - por símbolos, alegorias, rituais, mitos (CARVAlHo, 1990, p.10).

Em Portugal, as comemorações cívicas camonianas do ano de 1880 foram emblemáticas para assinalar as práticas pioneiras do processo de legitimação de um novo regime, buscando definir novas identidades e objetivos para o povo, cuja união residiria não somente na coletividade instituinte do evento, mas também na identificação dos inimigos comuns. Naquela ocasião, o partido republicano se fez presente promovendo seus ideais perante a sociedade, a grande confraternização cívica envolveu vários setores sociais e, por todo o país, indivíduos das mais variadas proveniências ideológicas além dos 'jacobinos'. De acordo com alguns historiadores (CAtroga, 2005), essa festividade pode ser considerada a gênese do Partido Republicano. Os seus promotores procuraram dar uma conotação cívica à solenidade que, inspirada no positivismo, ia ao encontro da mensagem veiculada pelo movimento a que pertenciam: eles apropriaram-se da figura do Épico, símbolo de um período de grandeza pátria, para, em contraponto, destacarem o estado de decadência da sociedade monárquica portuguesa propondo o regime republicano como a alternativa mais promissora para o país (CATROGA, 2000, p.34).

Considerada como tributária dos postulados essenciais da modernidade política e caracterizada pela organização dos poderes, nos direitos e deveres fundamentais dos cidadãos, das questões relativas ao sufrágio universal e a cobertura legal dada à laicização da sociedade, tais como, a separação da Igreja do Estado, o registro civil obrigatório, a neutralização religiosa do ensino, a secularização dos cemitérios, entre outros (CATROGA, 2000), a ordem constitucional republicana emergia, no contexto de finais do século XIX e início do XX, como modelo de organização política a ser adotado pelos países que se desejassem modernos e desenvolvidos ${ }^{88}$.

\footnotetext{
${ }^{88}$ Cabe destacar, que em Portugal, a separação entre Estado e Igreja já havia sido iniciada, por meio dos esforços do Marquês de Pombal ainda no século XVIII. Representante do pensamento iluminista português, Marquês de Pombal realizou reformas para regenerar Portugal por meio do investimento na formação letrada. Para o ministro, o conhecimento não poderia ser privilégio das ordens religiosas, nem um saber dogmático, mas deveria ser um conhecimento público com bases científicas. "A ação políticopedagógica do Marquês de Pombal, dentre outros aspectos, assinalava como uma necessidade histórica o Estado tomar para si o controle das questões do ensino em todos os seus níveis (...). Agir sobre a
} 
Tendo em vista seu potencial disseminador de uma determinada visão de mundo e concepção de história, as festas logo se tornaram lugar de luta pelo poder, as comemorações, e o que elas deveriam celebrar, tornar-se-iam etapa essencial dos projetos políticos de edificação dos Estados-Nação no decorrer do século XIX. As sociedades modernas secularizadas deveriam engendrar um conjunto de representações que apelassem para o sentimento e para a solidariedade e, as festividades comemorativas dos centenários, dos grandes nomes e feitos da história, por exemplo, possibilitaram a criação de um clima de sublimação e de engrandecimento da pátria (CATroga, 2005, p. 105).

As comemorações cívicas realizadas no período mobilizaram explicitamente a memória, chamando-a a desempenhar a mesma função pedagógica que era atribuída a toda a literatura histórica; estas comemorações foram criadas para serem vividas como manifestações simbólicas, em que se afirmava a continuidade histórica dos povos e da humanidade, lembrando que "quando na memória de um povo se obliteram os interesses nacionais e a sua missão no mundo, esse povo corre o perigo de perecer de inanição" (CATroga, 2005, p. 109). Desse modo, as comemorações passaram a existir baseadas na percepção, sentida pela Revolução Francesa ${ }^{89}$, de que as representações racionais só seriam mobilizadoras se fossem completadas por uma vivência cultual que, tal como no rito religioso, conferisse significado simbólico e coletivo ao sentido do tempo e, simultaneamente, congregasse as consciências divididas à volta de memória(s) consensuai(s) (idem, p. 110). A rememoração deveria ser feita em honra e para o prestígio da humanidade, para marcar estágios nesse caminhar e não para impor em nome de um passado às novas gerações, a adoração dos seus fetiches, a idolatria dos seus deuses (CATROGA, 2005).

No Brasil, os monarquistas e os republicanos foram os dois grupos em conflito explícito em finais do século XIX e início do XX, sendo que cada qual buscava construir sua interpretação dos fatos históricos. A versão republicana da história do

institucionalização de um sistema de ensino denotava projetar o futuro político da nacionalidade (BоTо, 2011, p. 16). No Brasil, Marquês de Pombal expulsou a Companhia de Jesus, principal instituição religiosa responsável pelo ensino no país e realizou o que pode ser considerada a primeira reforma da instrução, expressando o intento da coroa portuguesa de colocar a educação como matéria do Estado.

${ }^{89}$ Foi inegável a influência da Revolução Francesa na constituição das festas cívicas nos dois países. Foi ela que, pela primeira vez, as estabeleceu constitucionalmente no ano de 1791, ao declarar: "Serão estabelecidas festas nacionais para conservar a recordação da Revolução Francesa" (OLIVEIRA, 1989, p. 173). Em abril de 1792, realizar-se-ia a Festa da Liberdade, oportunidade na qual os franceses aproveitaram para divulgar a divisa representativa da revolução: "Liberdade, Igualdade, Fraternidade" (CONDORCET, 2008) para todo o hemisfério ocidental. 
Brasil buscou retomar os movimentos precursores da República e, assim, demonstrar que este regime foi historicamente constituído como uma aspiração nacional, ou seja, como a consolidação de uma tradição já existente na pátria brasileira. Por outro lado, os monarquistas afirmavam que a monarquia havia dado ao país mais de setenta anos de paz interna, além de garantido a unidade nacional, o progresso, a liberdade e o prestígio internacional e, por isso, era o modelo mais legítimo de organização do país. O eixo central da argumentação monarquista estava na unidade nacional garantida pelo Império, contraposta à ameaça de desmembramento relacionada à República (CARVAlho, 1990).

Os republicanos e monarquistas construíram suas memórias específicas e lutaram por torná-las estáveis; entretanto, o universo simbólico engendrado pelos republicanos não conseguiu conferir total legitimidade ao regime político de forma independente do regime anterior. Por outro lado, os monarquistas não foram fortes suficientes para restaurar a Monarquia, mas continuaram atestando a supremacia de sua interpretação sobre a história do Brasil, ao afirmarem que só o Império foi o garantidor da unidade nacional e fez, dessa unidade, a questão mais importante da vida política brasileira. A competência dos historiadores monarquistas na defesa de sua versão histórica pôde ser justificada pelo fato deles comporem a elite letrada de "alta linhagem" no período, e também pela divulgação privilegiada de sua interpretação através de instituições influentes socialmente como o Instituto Histórico e Geográfico Brasileiro, criado em 1838. Desse modo, coube aos republicanos manterem a ideia de unidade presente no Império através de pactos como o das forças oligárquicas, a política dos estados ou dos governadores e a do federalismo à brasileira (OLIVEIRA, 1989), ou seja, identificou-se muito mais um movimento de continuidade do que de total ruptura com os ideais sociais anteriores.

A continuidade também pôde ser evidenciada na retomada de um conjunto de discussões acerca da temática educacional, especialmente realizadas por médicos, higienistas, advogados e políticos ${ }^{90}$ que, ao ser transformada na bandeira política dos primeiros reformadores republicanos, foi levada às últimas consequências na publicização do regime como o mais adequado para garantir o progresso necessário e um lugar no rol das nações desenvolvidas. A imagem da escola como arauto da nova

\footnotetext{
${ }^{90}$ Sobre a discussão acerca das relações entre os discursos médico, higienista, político e educacional no século XIX ver GONDRA, J. G. "Medicina, Higiene e Educação Escolar". In: Eliane Marta Teixeira Lopes; Luciano Mendes de Faria Filho; Cynthia Greive Veiga. (Org.). 500 anos de Educação no Brasil. Belo Horizonte: Autentica, 2003, v. 1, p. 519-550.
} 
nação deveria extravasar o contexto especificamente escolar, para se projetar em uma intervenção social mais ampla. Nesse sentido, percebeu-se que o destaque dado aos sistemas públicos e estatais de ensino na constituição dos Estados nacionais ganhou grande visibilidade com os republicanos, que tornaram a educação, a bandeira do novo regime.

A recuperação de um determinado maquinário para a realização das festas políticas e sociais também recebeu inspirações de outros tempos. As comemorações cívicas imperiais, por exemplo, assim como aconteceria com as republicanas, almejaram demonstrar de forma concreta através das imagens, discursos, símbolos e alegorias, os valores sociais que identificavam a comunidade e informar sobre as estratégias políticas de legitimação do poder, moralização e educação do povo, bem como instituir a rede de sentidos e significados com base nos quais a população deveria construir uma identidade nacional e uma imagem de si mesmo (CHAMON, 2002; POMPÉIA, 1998; OLIVEIRA, 1989) $)^{91}$.

Ainda acerca da questão da possibilidade de confirmação de uma determinada ideologia por meio das comemorações cívicas, é significativo lembrar que a simples realização de uma festa e a participação do povo nesta, não é fator comprobatório da adesão e aceitação de toda a população, nem garantia de que a festa foi apropriada por todos da mesma maneira. Tal afirmação pode ser exemplificada pelo caso da festa de "sete de abril", realizada pelo povo mineiro no ano de 1832 (CHAMON, 2002). Apesar de ter sido instituído a obrigatoriedade da participação popular, vislumbrada por meio da colocação de luminárias em frente às residências, nem todos as providenciaram; essa ausência era sentida como uma provocação do morador da casa aos idealizadores do evento que, assim, não se juntava a celebração da causa da pátria. Com isso, não quero afirmar que as festas cívicas não eram aceitas e/ou compreendidas pela população escolar e social, mas que é importante (termos em mente) que as festas podem revelar outras apropriações e usos que não aqueles idealmente imaginados e registrados nos relatos oficiais, relativizando assim o seu caráter homogeneizador.

A explosão do "espírito comemorativo" e o reconhecimento de sua importância aconteceram durante o século XIX de forma conjunta à emergência das nações ocidentais que prescindiu, neste contexto, da reorganização e disciplinarização dos

\footnotetext{
${ }^{91}$ Faz-se relevante destacar que além dos monarquistas e republicanos tiveram parte no processo de elaboração do calendário civil que depois se tornaria republicano, membros da Igreja Positivista do Brasil - IPB (LEAL, 2006).
} 
indivíduos, construindo para eles uma versão da memória histórica nacional condizente com a nova organização social e política (OLIVEIRA,1989). Os historiadores, publicistas, ideólogos e educadores foram os principais responsáveis por engendrar a memória histórica nacional, principalmente, a partir da organização das comemorações e das festas oficiais, que tinham como objetivo dar legitimidade as tradições inventadas (Hobsbawn, 1984). No Brasil,

Os republicanos instituíram suas festas procurando estabelecer uma continuidade com eventos históricos passados; valorizaram a lembrança de feitos e heróis até então perdedores. A República os resgatava em sua dignidade e valor. A proposta da tradição republicana não destacava a singularidade do país e sim seu pertencimento a uma fraternidade com países e/ou momentos visualizados como representantes do lema: liberdade, igualdade, fraternidade (OLIVEIRA, 1989, p. 185).

Existem indícios de que tradições políticas e sociais relacionadas ao regime político republicano em diferentes países tiveram que ser inventadas ou reelaboradas para contraporem-se às existentes no período monárquico, e a forma pela qual se deu esta escolha é objeto de estudos de pesquisas que se realizam ainda nos dias de hoje, de maneira interdisciplinar com a colaboração de sociólogos, antropólogos e outros estudiosos (HobsBAwn, 1984). De acordo com esse autor, o fenômeno nacional, observado em diversos países do Ocidente no decorrer do século XIX, só pode ser devidamente compreendido a partir do processo de "invenção das tradições" que pode designar tanto as tradições realmente inventadas, construídas e formalmente institucionalizadas para compor um imaginário social coletivo, quanto as que surgiram em um período mais difícil de delimitar e se estabeleceram com enorme rapidez por meio de estratégias de grande aceitação popular, como por exemplo, as comemorações. Enfim,

Por "tradição inventada" entende-se um conjunto de práticas, normalmente reguladas por regras tácitas ou abertamente aceitas; tais práticas de natureza ritual ou simbólica visam inculcar certos valores e normas de comportamento através da repetição, o que implica, automaticamente, uma continuidade em relação ao passado. Aliás, sempre que possível, tenta-se estabelecer continuidade com um passado histórico apropriado (HOBSBAWN, 1984, p.09).

Entretanto, um dos aspectos que deve ser considerado no estudo das tradições é que elas podem estabelecer uma continuidade bem artificial com um passado histórico e até mesmo retomar situações, relatos e cenas antes irrelevantes e que passam a ganhar novo significado. Ao ser considerada uma espécie de reação a situações novas 
assumem, ora uma forma de referência a situações anteriores para a retomada de características familiares como forma de continuidade entre o passado e o presente, ora estabelecem seu próprio passado através da repetição obrigatória de fatos aleatórios. A tradição inventada emergiria sempre em um meio social em constante mudança e inovação que buscaria, em última instância, estruturar de maneira imutável e invariável alguns aspectos da vida em sociedade com o objetivo de manter uma estrutura estável e segura para a população (HOBSBAWN, 1984).

As tradições inventadas estiveram relacionadas não somente com as mudanças dos ideários políticos partidários, mas antes relacionadas com a construção histórica do termo nação. Os estados nacionais foram generosos na definição de hinos, bandeiras, imagens e símbolos que deveriam "personificar" a nação, garantindo-lhes o sentido de identidade e expressando sua soberania. De acordo com OlIVEIRA (1989), conceitos como legitimidade, soberania e cidadania foram centrais na construção da nação e se fizeram presentes na organização da tradição e da memória coletiva, constituinte da identidade nacional.

A hipótese de Hobsbawn (1984) é de que a invenção das tradições ocorre com mais frequência quando uma transformação rápida da sociedade debilita ou destrói os padrões sociais para os quais as "velhas" tradições foram feitas, produzindo novos padrões com os quais essas tradições são incompatíveis e incapazes de se $\operatorname{adaptar}^{92}$. No âmbito internacional, as tradições inventadas desde a Revolução Industrial (século XVIII), segundo esse autor, podem ser classificadas em três categorias superpostas, a saber: a) aquelas que estabelecem ou simbolizam a coesão social ou as condições de admissão de um grupo ou de comunidades reais ou artificiais; b) aquelas que legitimam ou estabelecem instituições, status ou relações de autoridade e c) aquelas cujo propósito principal é a socialização, a inculcação de idéias, sistemas de valores e padrões de comportamentos.

No caso do estudo das festas cívicas brasileiras e portuguesas, percebeu-se que a invenção e reelaboração de determinadas tradições como forma de se diferenciar e recuperar alguns aspectos do passado histórico comum relacionou-se, desse modo, com a terceira categoria de tradições engendrada por Hobsbawn (1984), cujo propósito principal foi a socialização, a inculcação de idéias, sistemas de valores e padrões de

\footnotetext{
92 Neste trabalho, consideram-se como exemplos destas transformações, a Proclamação da República Brasileira (1889) e Portuguesa (1910), realizadas de acordo com os anseios de determinados grupos sociais.
} 
comportamentos, isto é, um determinado habitus, por meio da organização das instituições de ensino.

O uso do termo tradição inventada na análise das festas escolares nos permitiu desvencilhar da conotação negativa que identificava o termo tradição como algo arcaico, em desuso ou mesmo dogmático. As tradições estão sempre se reinventando em função dos seus diferentes usos e no âmbito das comemorações escolares isto não foi diferente. Nas palavras de Carvalho (2004), uma tradição pública é um saber do povo, de uma nação ou civilização, na qual os novos são iniciados. Trata-se de uma prática histórica "que herdamos, incorporamos e inovamos, de um legado cultural específico, cujos critérios de uso e avaliação são públicos e sujeitos a constantes transformações, como as línguas, as ciências, as artes etc" (CARVALHO, 2004, p. 96). O recurso à história e aos ensinamentos da antropologia e da sociologia era feito de acordo com os interesses ideológicos dos republicanos das diferentes vertentes ideológicas, que anunciavam os conceitos de civilidade, de civismo e de civilização presentes no âmbito escolar como os anúncios de um projeto de país moderno (Вото, 2004; 2010).

Ao engendrar sua própria racionalidade, a escola civilizou-se por meio dos conhecimentos escolares que se aliaram ao ensino de certas competências de um dado repertório coincidente com a orientação de valores e de saberes a serem percorridos, para que fossem formadas as idéias de pátria, de família, de criança, de disciplina, de cidadão, para retomar as que interessam ao estudo. Ao produzir sua cultura, a escola valeu-se de estratégias de apropriação de outros significados culturais e os modos pelos quais a escola criou e recriou os mesmos carregou as marcas de tal projeto civilizador, cujo progresso só poderia ser realizado se viesse acompanhado do devido esforço de moralização (Вото, 2010). As festas cívicas escolares que não se resumiram nas comemorações das datas cívicas oficiais, deveriam contribuir para o novo regime demonstrando o progresso do país, entendido como uma visão positiva do futuro e apresentado um novo modelo de cidadão republicano a ser incorporado por todos, e contribuindo para a constituição de um imaginário político, histórico e social consoante às novas propostas dos dirigentes. 


\section{2 - O civismo com conteúdo escolar a ser ensinado}

A partir do momento em que o civismo, entendido como conteúdo fundamental para o processo de formação do cidadão comprometido com o progresso da sua pátria, se constituiu como comportamento social relevante a ser ensinado, as escolas, como instituições representativas do Estado, foram chamadas para cumprir esta obrigação, e esse conteúdo e valor escolar, passou a ser ministrado em diferentes momentos do currículo e também nas oportunidades festivas. Além da formação do cidadão, o ensino do civismo e da cidadania foi concebido pelos educadores da época como a vertente educacional privilegiada para a concretização dos ideais políticos no sistema educacional. Considerado o verdadeiro sentido da educação, o civismo deveria estar presente em diferentes atividades cotidianas do âmbito escolar, nas festas comemorativas de eventos históricos ou de homenagens aos heróis nacionais ${ }^{93}$. Os "heróis" e "acontecimentos importantes" eram selecionados de acordo com a sua relevância para a construção de uma memória histórica oficial e comum a todos os indivíduos. No âmbito educacional,

A missão da escola relativa ao ensino das tradições inventadas preferencialmente a coesão nacional em torno de um passado único, construtor da nação, - justificava a preocupação na organização das atividades cívicas criadas para reforçar essa memória (BITTENCOURT, 1988, p. 47).

Tal ensinamento, de acordo com certos educadores da época, atingiria melhores resultados se mobilizassem os sentimentos e as emoções no seu aprendizado. Neste caso, o modelo de aprendizagem tradicional, baseado especificamente na postura passiva do educando, na grande atenção ao intelecto e na memorização, não conseguiria atingir os resultados esperados; mobilizaram-se, então, as premissas renovadas que promoveriam a formação integral do educando (moral, social, afetiva e intelectual) por meio do ensino ativo e da manutenção do interesse dos educandos. Em outras palavras, o ensino do civismo deveria ser aprendido com o auxílio de todos os sentidos, não somente do intelecto; as comemorações escolares apresentaram-se como situações

\footnotetext{
${ }^{93}$ Nunes (2003), afirma que a temática do herói nacional, sua função e necessidade na literatura pedagógica, não têm recebido a atenção que merece, embora seja um tema recorrente nos manuais escolares destinados à escola primária em variados contextos históricos. Para a autora, o mito do herói também está presente na atuação dos intelectuais educadores nos projetos educativos que gestaram: "seja o heroísmo épico e a vontade hercúlea de fazer a história; o heroísmo trágico e a ameaça da incompreensão, da injustiça, do desgosto, seja o heroísmo pícaro, cuja única preocupação é sobreviver" (NUNES, 2003, p. 395)
} 
profícuas para esse intento, já que permitiam a convivência da emoção e da razão em um projeto comum “(...) educando 'pela representação ou evocação de fatos dignos de ser imitados', as festas forneciam às crianças oportunidade para gravar, na memória das experiências, muitas lições proveitosas" (CARVALHO, 1989, p.77).

Essas práticas, organizadas e fiscalizadas pelas autoridades educacionais sob a ótica do nacionalismo vigente, conceberam a escola como a instituição fundamental engendrada pela "nação" para formar o cidadão (BITTENCOURT, 1988, p.45) e disseminar o civismo. Além dessas ações, em diferentes estados brasileiros foram criadas ainda as Ligas de Defesa Nacional $(1916)^{94}$, cujas atribuições relacionaram-se ao desenvolvimento do civismo, ao culto do heroísmo, ao estudo da história do Brasil e das tradições nacionais e a propagação da educação profissional, bem como a organização de grupos de escotismo. Apesar de se tratar de uma instituição social, as Ligas viram as instituições de ensino como capazes de corporificar esses ideais por meio do culto à Bandeira, no ensino de músicas e de poesias de autores brasileiros, na divulgação de livros e leituras imbuídos de valores morais e cívicos, no exercício de uma disciplina e respeito às leis e autoridades (COELHO, 2008).

Cabe destacar que o ensino do civismo se relacionou de forma bastante estreita ao regime político republicano, considerando que no decorrer de todo o século XIX, e especialmente com a constituição dos estados nacionais, procurou-se forjar o ideal de cidadão. Neste caso, a formação do indivíduo não deveria acontecer para uma sociedade organizada em um regime político abstrato, mas a escola deveria cuidar da constituição do cidadão para a República, que era concebida como a única fonte de virtude, capaz de homogeneizar (quase) todas as diferenças, e o único regime que conferiria igualdade política, permitindo a qualquer homem, mesmo os de origem humilde, "chegar a presidência do país ou à propriedade de uma fábrica" (NUNES, 2000). Contudo, a incongruência dos ideais republicanos residiria no fato de, ao mesmo tempo em que a República garantia formalmente a igualdade política, ela também legitimava uma prática de manutenção da desigualdade. Os ex-escravos e as classes trabalhadoras de imigrantes, por exemplo, constituíram presença incômoda nos centros urbanos, mas, para estes, a educação também seria a solução:

Regenerar as populações brasileiras, núcleo da nacionalidade, tornando-as saudáveis, disciplinadas e produtivas, eis o que se

\footnotetext{
${ }^{94}$ A Liga de Defesa Nacional foi criada em 1916 pelos intelectuais Olavo Bilac, Pedro Lessa e Miguel Calmon, com o objetivo principal de congregar os sentimentos patrióticos dos brasileiros de todas as classes sociais (NAGLE, 1978).
} 
esperava da educação, erigida nesse imaginário em causa cívica de redenção nacional (CARVALHO, 1989, p.10).

Os efeitos civilizadores das festas extrapolaram os conteúdos aprendidos nas salas de aulas e permearam o imaginário da população que participava desses eventos. A presença da população nas festas, noticiada nos discursos e nas fotografias publicadas nas revistas, era considerada condição imprescindível para o sucesso das mesmas. As festas confirmavam para a sociedade presente, os avanços alcançados pela escola na educação e o desenvolvimento das crianças; ao mesmo tempo, esta mesma população, participando dos eventos festivos, poderia se instruir em sentimentos, valores e normas cívicas.

No dia 15 de novembro o Grupo Escolar 'Alfredo Pujol' realizou no teatro daquela cidade uma esplêndida festa a que concorreu a maioria da população que sabe apreciar os notáveis progressos que se tem manifestado no ensino público primário. A festa constou de comédias, cantos, poesias, etc.

E o digno diretor que soube preparar e ensaiar as diversas partes do programa, sem prejuízo das horas do trabalho no grupo, mereceu os elogios de toda a população" (A Eschola Publica, dezembro de 1897, p.360-361).

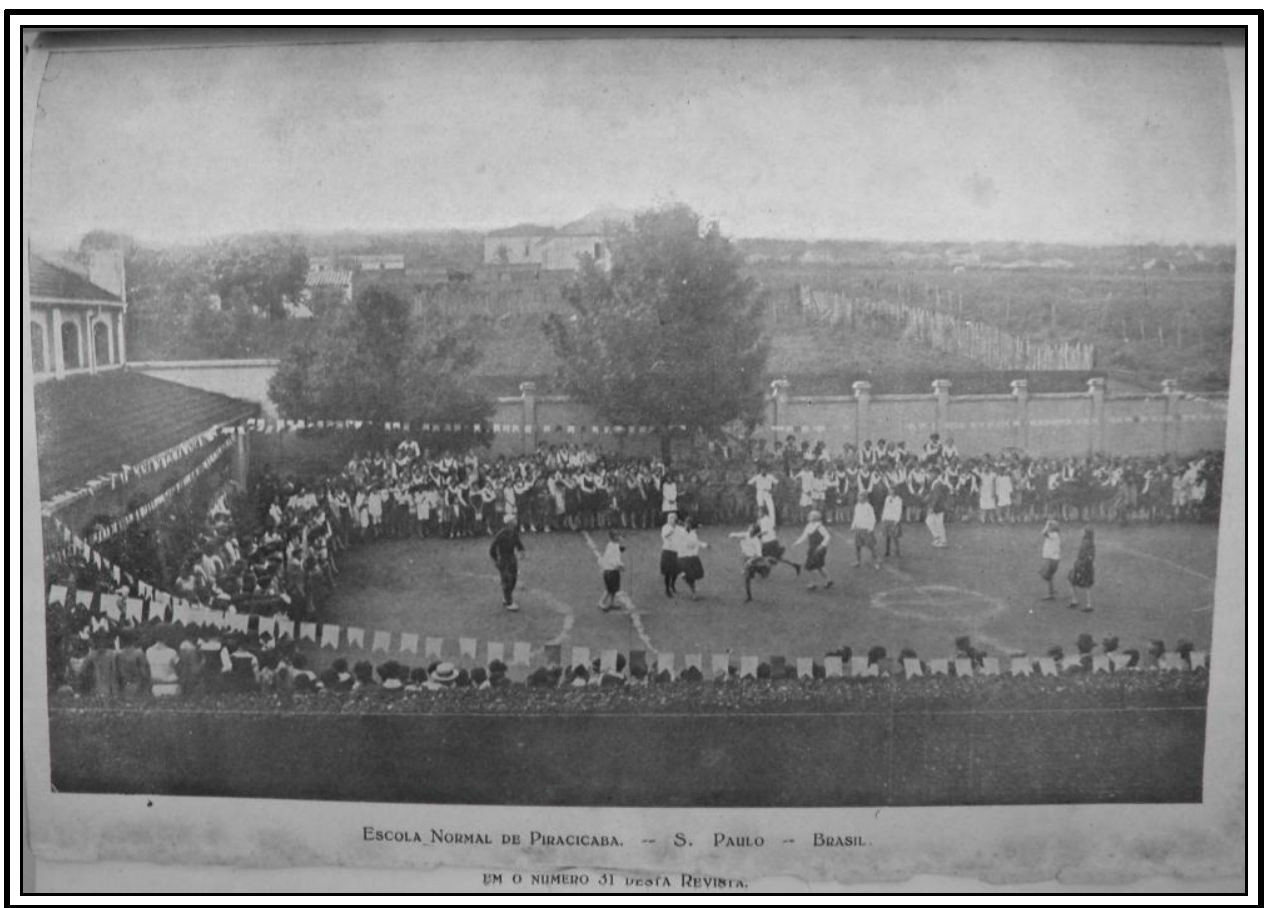

Escola Normal de Piracicaba - S. Paulo - Brasil

Revista Escolar, agosto de 1927, p. 81. 


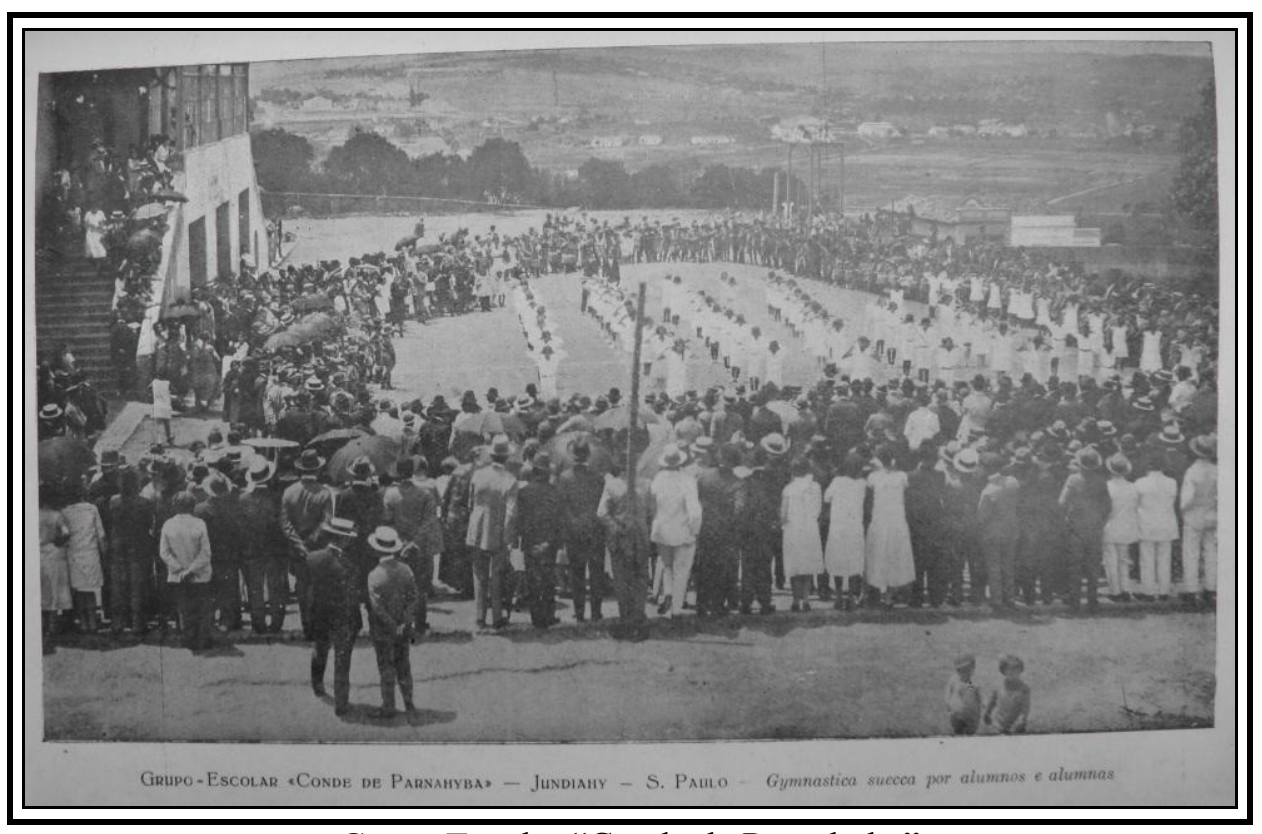

Grupo Escolar "Conde de Parnahyba"

Anuário de Ensino do Estado de São Paulo, 1926, p. 499.

A escolha das datas cívicas foi expressiva para a organização do regime republicano no contexto brasileiro e português. Em Portugal, os dias das festas cívicas tiveram como objetivo, além de propugnar um novo ideal de nação e de cidadãos, suprir o espaço vago deixado pela restrição dos cultos e festas religiosas na sociedade. Os republicanos compreenderam que era preciso utilizar estratégias que extrapolassem a assimilação intelectual dos novos conteúdos, e que atingissem a dimensão afetiva da educação como costumava acontecer nas comemorações cívicas. Além disso, era conhecido o fato de que o que mais atraía a população à religião não eram os dogmas e os sermões, mas as manifestações exteriores do culto e a dimensão do espetáculo que lhes estavam associados (DURKHEIM, 1996). Era preciso substituir os rituais, cultos e símbolos religiosos por outros, inspirados no laicismo, tais como os cultos da pátria, as comemorações dos centenários, os cortejos cívicos divulgadores dos novos símbolos nacionais, os novos feriados laicos e os heróis nacionais retirados da galeria política e social. Algumas dessas estratégias eram utilizadas desde a época da Monarquia Portuguesa em propagandas republicanas ${ }^{95}$.

Em Portugal, a lista de feriados laicos era composta das seguintes datas: $1^{o} d e$ janeiro, em homenagem à humanidade, data comum entre Brasil e Portugal; 31 de janeiro e 5 de outubro dedicados à comemoração do regime republicano,

\footnotetext{
95 Ver, por exemplo, as comemorações do centenário de Camões (1880), e de Pombal (1882), além do uso de recursos como as bandeiras e os hinos associados aos centros republicanos (PINTASSILGO, 1998).
} 
representativas do esforço de associação da ideia de Pátria à República; 3 de maio, comemoração do descobrimento do Brasil, referência explícita ao período áureo português e a grandeza da Pátria portuguesa e o $1^{o}$ de dezembro, comemorativo da independência da Nação - Restauração. Datas que indicavam que o amor da humanidade e pela Pátria poderiam ser conciliáveis (PINTASSILGO, 1998) ${ }^{96}$.

No caso brasileiro, as datas cívicas a serem comemoradas pela República foram instituídas em 1890, com a promulgação do Decreto $n^{\circ} 155-B$, de 14 de janeiro daquele mesmo ano. Este decreto retomou algumas especificações dos dias de festas nacionais determinados pelo Governo Provisório de 1889, afirmando que o profundo sentimento de fraternidade universal, sob o qual o regime republicano se fundaria, não poderia se desenvolver de forma conveniente sem um sistema de festas públicas, "destinadas a comemorar a continuidade e a solidariedade de todas as gerações humanas" (Decreto $n^{o} 155-B$ de 14 de janeiro de 1890). De acordo com a lei mencionada, cada pátria deveria instituir tais festas segundo os laços que as prenderiam aos seus destinos e aos de todos os $\operatorname{povos}^{97}$. As festas republicanas brasileiras almejaram assinalar a continuidade com o passado, ou com parte desse passado, muito mais do que iniciar ou retomar princípios revolucionários, como aconteceu no caso francês. A proposta da invenção da tradição republicana destacou ainda o seu pertencimento a uma fraternidade que se desejou universal "com países e/ou momentos visualizados como representantes do lema: liberdade, igualdade e fraternidade" (OLIVEIRA, 1989, p. 185).

Os dias selecionados para figurarem no calendário republicano brasileiro mesclaram eventos e referências nacionais importantes em diferentes momentos políticos. Foram elas: 21 de abril, consagrado à comemoração dos precursores da Independência do Brasil, personificado na figura de Tiradentes; 3 de maio, assim como em Portugal, consagrado à comemoração da descoberta do país; 13 de maio, consagrado à comemoração da fraternidade dos brasileiros; 14 de julho, consagrado à comemoração

\footnotetext{
96 No âmbito escolar, a estas datas de temas cívicos, outras foram acrescidas, como por exemplo, a comemoração do Natal, as festas de encerramento do ano letivo e de exposição dos trabalhos escolares, a Semana da Bondade, a Semana da Criança, além das homenagens feitas aos professores e personalidades representativas da história do país, que serão analisadas em outros capítulos.

${ }^{97}$ Caberia a cada pátria instituir tais festas, que prenderiam seus destinos aos destinos de todos os povos. As festas deveriam garantir não só a fraternidade dos indivíduos pertencentes a uma determinada nação, mas de todos os povos do mundo; talvez, por este motivo, a inserção de datas comemorativas de outros países no calendário republicano brasileiro não soasse tão estranho aos reformadores da época.
} 
da República, da Liberdade e da Independência dos povos americanos; 7 de setembro, consagrado à comemoração da Independência do País; 15 de novembro, consagrado à comemoração da proclamação da República e Festa da Bandeira, realizada no dia 19 de novembro. Acrescentou-se a essas datas, o dia 24 de fevereiro, quando se comemorou a promulgação da Constituição da República, festa nacional decretada pelo Congresso Nacional no ano de $1891^{98}$.

Nas escolas portuguesas, a celebração das datas cívicas poderia ser feita com menor pompa, por meio de uma preleção no âmbito da sala de aula por um aluno e/ou pelo professor, como consta em notícia publicada no periódico A Escola Primária de 31 de outubro de 1929:

Às Regiões Escolares foi do Ministério da Instrução expedida uma circular determinando que em 10 de Novembro, aniversário do armistício, nas escolas fossem feitas preleções aos alunos sobre a Paz, renúncia a guerra e estabelecimento do princípio de recurso à arbitragem nos conflitos entre os povos (A Escola Primária, 31 de outubro de 1929, p. 460).

Ou em outros momentos "com o estralejar de foguetes, palavras patrióticas, desfiles emocionantes de crianças, recitações cheias de fé nos destinos da pátria portuguesa" (A Escola Primária, 20 de dezembro 1935 - 05 de janeiro 1936, p. 05), que poderia ser realmente sentida e mantida de forma indelével na memória dos organizadores e dos assistentes presentes:

As comemorações do $1^{\circ}$ de dezembro tiveram este ano um luzimento invulgar nas escolas primárias. A Direção Geral ordenou que se fizessem festas; mas quando estas se não sentem, obedece-se apenas, resultando daí festejos apagados, sem interesse.

Como o $1^{\circ}$ de dezembro, porém, não sucedeu assim. O professorado primário é patriota, e por isso se associou aos desejos do Alto, de alma e coração.

Pelo relato dos jornais, viu-se que por esse país além as escolas estiveram em festa, estralejaram foguetes, esfuziaram palavras patrióticas, houve desfiles emocionantes de crianças, recitações cheias de fé nos destinos da Pátria - o que tudo contribuiu, sem dúvida, para radicar no coração das crianças o amor à liberdade, nesta terra linda, que se chama Portugal (A Escola Primária, Portugal, 20 de dezembro - 5 de janeiro, 1935 - 1936, p. 05).

A data da Restauração Portuguesa, $1^{\circ}$ de dezembro, foi comemorada de forma mais incisiva pelas escolas públicas nas décadas iniciais do século XX, de forma a

\footnotetext{
${ }^{98}$ De acordo com Oliveira (1989), as festas republicanas brasileiras poderiam ser divididas em duas categorias: aquelas que privilegiaram a fraternidade universal (1 de janeiro e 14 de julho), e as que se referiam mais diretamente à fraternidade nacional (21 de abril; 3 de maio; 7 de setembro e 15 de novembro).
} 
associar elementos da política vigente e da natureza como representativa do país. A ação de plantar árvores naquela ocasião foi concebida como ato simbólico de recuperação dos feitos do passado e de crença no futuro. Utilizadas como recurso auxiliar na construção da idéia do civismo, as árvores, com o passar do tempo, ganharam momentos exclusivos de celebração com as festas da natureza, que discutiremos em outra parte deste capítulo. A celebração de tão importante data associada ao plantio de uma árvore deveria contribuir para a supressão dos temores e das incertezas do porvir, recuperando os acontecimentos notáveis e heroicos do passado. Desse modo, era possível incutir nas crianças o amor pela pátria e o sentimento do nacionalismo; saindo de suas escolas, essas crianças plantariam em um lugar específico algumas mudas de árvores:

No dia $1^{\circ}$ deste mês celebrou-se mais uma vez a data gloriosa da Restauração de Portugal.

Nos tempos que vão decorrendo, de incertezas e temores do porvir, quanto se faça é pouco para incutir no espírito das crianças o amor por este torrão banhado de luz e sol, que as viu nascer, e que os seus avós de antanho resgataram do poder de estranhos, sacrificando para isso vidas e sangre e haveres.

Em Lisboa efetuou-se nesse dia uma formosa parada de crianças na Tapada da Ajuda, onde foram assistir à plantação dalguns centos de árvores.

Festa bonita, como todas as em que entram crianças, e que elas lembrarão pela vida fora, se é certo que, para se ser alguém, uma das condições é haver plantado uma árvore, tão intimamente ligada à vida do homem esta a dos seres inferiores.

Mas, uma pergunta nos ocorre:

Não seria, porventura, mais proveitosa a lição se cada escola plantasse árvores na área de sua região?

Proveitosa e, vamos lá, econômica, o que não é desperdício na época presente (A Escola Primária, Portugal, 1936, p. 08).

No Brasil, entre todas as datas cívicas, o sete de setembro teve uma expressão maior, pois se tratava do dia dedicado à Pátria, reconhecendo-se nos seus festejos um tributo prestado pelo povo à Nação. As celebrações poderiam contar em seus programas de discursos cívicos acerca da data, seções literário-musicais, demonstrações de ginástica, jogos escolares (Revista Escolar, outubro de 1926), desfiles dos batalhões infantis (Revista de Ensino, outubro de 1903) e apresentações teatrais, conforme ficou registrado nas páginas da Revista de Ensino de setembro de 1916. Nesta direção, cabe retomarmos, a título de exemplo, a peça realizada pelos alunos no ano de 1916. Os personagens daquela peça foram assim discriminados: Eliseu, estudante, menino de 11 anos; Natalia, irmã de Eliseu, menina de 10 anos; Achilles, criado, menino de 10 anos; 
Waldomiro, amigo e colega de Eliseu, menino de 8 anos; Arnaldo, professor, menino de 14 anos; Carlota, menina de 6 anos. A cena deveria se passar na sala de estudos, local no qual os alunos encetam uma conversa (texto apresentado em forma de diálogo), no qual discutem a respeito da data de "sete de setembro". No final da peça, todos os alunos retornam ao palco cantando uma música para a comunidade presente, da qual extraímos um excerto:

(...)

Coro

Festejemos a data mui gloriosa,

Que livrou o Brasil de Portugal;

Cantemos o nosso hino alegremente,

Lembrando o feito grande e imortal!

Salve, Pedro Primeiro! Salve, herói!

D'espada em punho em frente da corte,

Sacando o laço azul do velho reino

Deu o grito de "Independência ou Morte!" (Revista de Ensino, setembro de 1916, p.46).

As festas cívicas extrapolaram a orientação política de um determinado regime de governo no caso português, e estiveram muito mais próximas de um projeto maior de modernização da sociedade e da escola por meio da civilização do povo. Neste caso, tão importante quanto conhecer as datas escolhidas pelos dirigentes políticos para a celebração do civismo, foi investigar em quais outras ocasiões os conceitos de civilidade e civilização foram destacados como elementos ideais a serem perseguidos para a constituição do país como Estado Nação e da escola como a instituição moderna adequada à formação das novas gerações. Tanto no caso brasileiro quanto no português, as homenagens realizadas, os dias dedicados à reflexão sobre a bondade - Semana da Bondade e Dia da Boa Vontade em Portugal e a Semana da Criança no Brasil, nos deram pistas acerca dos conteúdos morais a serem ensinados e do aprendizado social que deveria ser o civismo.

É relevante perceber que ao mesmo tempo em que as festas constituíram uma cultura própria da escola, elas também contribuíram, de forma mais ou menos incisiva, para a consolidação de sistemas políticos e de um ideal de sociedade imaginados pelos governantes, desejosos do progresso de seus países. Elas contribuíram com estes intentos a partir do momento da sua preparação, nas aulas e nos ensaios, nos quais os estudantes estudavam textos, recitavam poesias, ensaiavam peças teatrais, aprendiam comportamentos (disciplina, obediência, perseverança e precisão) a serem disseminados para e aprendidos por toda a população no momento festivo. Por meio das festas, os 
indivíduos puderam ver concretizados os ideais, valores e normas da escola e de um projeto político para a sociedade: a festa era a representação de todos esses ideais concretizados. E a escola, atenta a todas estas demandas e influenciadas por elas, não poderia ser analisada de forma separada do contexto social, econômico, histórico e político do qual fazia parte.

\begin{abstract}
A data que recorda a nossa independência foi, este ano, brilhantemente comemorada pelos alunos dos nossos estabelecimentos de ensino, notadamente pelos alunos das escolas normais e anexas do Braz e da Praça da República. Em nota publicada no Jornal do Comércio da capital retoma-se o seguinte comentário: Já existe, há longo tempo, nas escolas do Estado, um dia escolhido para o "culto à bandeira Nacional", outro, em que se realiza o "culto às aves", e outro para o "culto à arvore". Encerram estas festas profundos conceitos educativos, uns morais e outros religiosos, além dos conceitos econômicos e positivos. São festas simbólicas, de que usam as escolas modernas, como um dos meios soberbos de cultura moral de mental (Revista Escolar, outubro de 1925, p.103-104).
\end{abstract}

Os rituais cívicos, nas escolas, eram planejados cuidadosamente pelas autoridades e pelos educadores que ocupavam cargos administrativos na Diretoria de Instrução Paulista com o conjunto de regras, métodos e a programação a ser cumprida no dia da solenidade. A utilização de uniformes e a execução de marchas e movimentos semelhantes aos do exército pelos alunos, também fizeram parte de algumas comemorações da época. O ensino do civismo na escola, pelos professores, visava contribuir para a invenção das "tradições nacionais" republicanas, que por sua vez, deveriam recuperar e ultrapassar as tradições do período imperial: "Uma tradição nova que deveria compor o imaginário do brasileiro era a do 'sentimento republicano' do povo" (BITTENCOURT, 1988, p.54). Tratava-se de formar o cidadão por meio de percepções sensíveis, como a bandeira e as árvores, em rituais escolares específicos para isso.

De acordo com Cardim (1916), educador brasileiro e autor de obras educativas no período, o sentimento de pátria e o culto de tudo o que diz respeito a essa "bela manifestação da alma" deveriam nascer no lar, desenvolver-se na escola e frutificar na sociedade. Mas, para que este processo se manifestasse nessa ordem, era preciso supor um trabalho prévio na escola, encarregada de formar a alma da criança para o civismo, e robustecer o seu caráter na escola do dever, para que, depois, se conseguisse, no lar, pais capazes de encarregarem-se da nobre "missão de desenrolar, aos olhos dos filhos, o painel sublime da pátria, capazes de segredar-lhes ao coração as belezas históricas do passado, capazes de desenvolver, os episódios épicos em torno dos grandes vultos do 
país" (CARDIM, 1916, p.03). A escola, para este autor, tinha como função principal "alimentar" sistematicamente na infância o "lume" do patriotismo latente.

Mas foi somente na gestão de Oscar Thompson (professor e inspetor do sistema público paulista), que as datas cívicas nas escolas públicas ganharam certa uniformidade, segundo contemporâneos do educador. Ao regulamentar os dias dedicados aos rituais cívicos escolares, recomendou que os mesmos fossem comemoradas sempre na véspera do dia indicado, já que uma aula de educação cívica deveria sempre ser dada em um dia letivo, bem como porque o dia nacional deveria ser feriado e consagrado exclusivamente às festas oficiais e as festas do povo, das quais as crianças teriam o dever de participar, reforçando, assim, o que tinha sido aprendido no contexto escolar.

As instituições de ensino particulares, tanto as confessionais quanto as leigas, também deveriam seguir o calendário instituído pelo Governo (Lei $n^{\circ}$ 1710, de 27 de dezembro de 1919 e Decreto $n^{\circ} 3205$, de 29 de abril de 1920), comemorando as datas nacionais brasileiras de modos mais simples, através de lições e conferências, ou mais elaborados pelas festas escolares. Esta prática era condição exigida para a autorização do funcionamento de tais estabelecimentos, sendo obrigatória a comunicação à Diretoria Geral da Instrução Pública sobre a forma que tivessem realizado a comemoração. Tal medida visou a divulgação dos valores cívicos por todas as instituições responsáveis pela instrução primária.

Capítulo III - Ensino Particular,

Artigo 26 - Além das condições exigidas para a autorização do funcionamento, ficam os diretores ou professores obrigados:

(...) A comemorar as datas nacionais brasileiras, por meio de lições, conferências ou festas escolares, comunicando à Diretoria Geral, no prazo de oito dias, a forma por que o tiveram feito.

$2^{\circ}(\ldots)$

Secretario do Interior, 29 de abril de 1920.

Oscar Rodrigues Alves (Anuário do Ensino do Estado de São Paulo, 1919, p.209).

A prática das festas cívicas tinha como objetivo representar e celebrar a identidade e soberania de um país independente, fomentar o sentimento de identidade do povo, consolidar um modelo de escolarização e configurar uma cultura própria da escola. Ao lado das datas históricas e da celebração dos símbolos cívicos, a temática do herói nacional, representado por Tiradentes ${ }^{99}$ no Brasil, tinha como função, inculcar nos

\footnotetext{
99 De acordo com Carvalho (1990), a escolha de Tiradentes deu-se devido a sua identificação com a simbologia cristã; sua vida pobre e humilde e seu martírio anterior à morte lembravam o de Cristo, e esta
} 
pequenos leitores certa forma de pensar e viver a nacionalidade. A celebração do "herói" da Inconfidência Mineira (1789), considerada um marco para outros movimentos como a Abolição da Escravatura (1888), e a República (1889), foi recuperada e intensificada pelos republicanos como personagem importante para a construção de uma identidade nacional coletiva. Seu patriotismo exacerbado e civismo constituíram-se aspectos indeléveis do ideário nacionalista republicano (FONSECA, 2002).

A Inconfidência foi escolhida como momento histórico precursor da construção do Estado Independente, e os inconfidentes, como pioneiros do republicanismo. As representações de Tiradentes no universo infantil, de acordo com Fonseca (2002), poderiam se dar de diferentes formas, seja através dos livros didáticos de história utilizados em sala de aula, dos concursos de redações e de desenhos promovidos por jornais e periódicos em determinados contextos, como também através das comemorações escolares. A partir de $1930^{100}$, por exemplo, nas comemorações de 21 de abril, realizavam-se as sessões cívico-litero-musicais, "que invariavelmente começavam pela execução dos Hinos da Bandeira, Nacional, da Inconfidência e a Tiradentes, acompanhados do hasteamento da Bandeira Nacional" (FonsECA, 2002, p.12).

Tiradentes e Rio Branco,

Um era militar e pouco lhe valia a existência, se a Pátria corresse algum perigo: a sua espada reverberava no espaço cintilações de vingança.

$\mathrm{O}$ outro era civil e apagou os últimos olhares como soldado num campo de batalha: a sua pena, fulgurante de civismo como o gládio de aço, espalhou bem longe o verbo das idéias, congregando as multidões.

Que queria Tiradentes?

(...)

Joaquim José da Silva Xavier queria o Brazil independente, sob a forma democrática; desejava independência e república - essas duas sublimes aspirações de todos os povos da Terra.

Outros brasileiros apareceram lutando pelas idéias de Tiradentes e hoje, a Sete de Setembro e a 15 de Novembro desejamos maldição a

associação pode até mesmo ser percebida na construção da imagem do herói, da qual não se possuía muitos elementos, mas logo se inventou barbas e cabelos longos, além de camisola comprida, numa explícita referência ao mártir cristão. A glorificação de Tiradentes no panteão dos heróis brasileiros também foi objeto de luta entre os republicanos e monarquistas. Para os monarquistas, Tiradentes havia idealizado a libertação da terra natal, concretizada por estes (OLIVEIRA, 1989). Entretanto, foram os republicanos que mais incisivamente celebraram a figura do herói como representativo do novo regime. ${ }^{100}$ Data na qual se inicia o período histórico brasileiro denominado "período Vargas", que vai de 1930 até 1945. 
seus algozes e ao seu nome eterna glória (Revista de Ensino, março de 1912, p.128).

A formação do cidadão foi trabalhada na pedagogia moderna a partir da consciência histórica e cívica, além da exaltação de condutas exemplares a serem perseguidas e da moralização social. A memória valorizada e celebrada era aquela que se poderia reconhecer como histórica e coletiva, considerada elemento fundamental para o sentimento nacional em primeiro lugar e, consequentemente, de modo ideal para a consciência de classe, étnica ou das minorias, sendo também constitutiva das lutas contra a opressão e dominação. As datas dignas de serem comemoradas, segundo LOVISOLO (1989), nos condicionam ao vínculo com a memória de modo positivo, público e intersubjetivo e precisam ser consideradas sob o crivo dessas condições.

As solenidades cívicas foram as mais recorrentes no contexto educacional brasileiro, sendo objetos de artigos em todas as revistas de ensino selecionadas durante todo o período delimitado para o estudo. Em 1922, ano do centenário da Independência do Brasil, a comemoração das datas de 15 de novembro, relativa à Proclamação da República, e 19 de novembro, Dia da Bandeira, tiveram um significado especial. Em 1922, o Anuário de Ensino do Estado de São Paulo publicou uma circular expedida aos diretores de Escolas Normais Profissionais, Escolas Reunidas e mestres das Escolas Isoladas, que apresentava as orientações para os festejos do centenário da Independência do Brasil que, segundo o documento, deveriam ter verdadeiro cunho popular e assumir as proporções dignas de um fato histórico a ser relembrado. As comemorações deveriam ser realizadas com o máximo brilho nos estabelecimentos de ensino, associando o povo aos festejos desses dias, e os discursos, feitos aos alunos perante o povo das localidades, deveriam evidenciar as vantagens do regime republicano sobre o monárquico.

Nas escolas públicas do Estado o Centenário da Independência foi festejado com entusiasmo e brilhantismo. Os escoteiros escolares tomaram parte saliente emprestando a todas as solenidades, esse cunho de sinceridade comovedora que é a alegria sadia da criança.

Houve em todas as Regiões de Ensino, concentrações preparatórias onde se reuniram cerca de 100.000 escoteiros escolares.

Em seu número de 8 de setembro de 1922, descrevendo o belo aspecto do Ypiranga na manhã do Centenário, dizia o "Correio Paulistano (...) Os 12 mil escoteiros que ontem formaram no Ypiranga, constituíram um dos elementos mais notáveis dentre todos os que na solenidade comemorativa do Centenário concorreram para emocionar os espectadores da grande festa que passou, de hoje em diante, para a lista dos fatos históricos da nossa terra (Anuário de Ensino do Estado de São Paulo, 1922, p.301-302). 
A análise dos programas, nos quais se propunha a organização dos dias de festa e das sugestões de atividades a serem realizadas nas mesmas, ambos publicados em revistas especializadas, evidenciaram o caráter pedagógico das atividades festivas tudo deveria ser organizado para garantir o maior aprendizado possível tanto dos alunos, quanto da população presente. As comemorações buscaram ensinar às crianças e aos adultos a representatividade de cada data, bem como os valores e virtudes associados ao novo regime político - a República. Os programas das festas escolares eram compostos, na sua maior parte, de homenagens ${ }^{101}$ às pessoas ilustres que compareciam nessas ocasiões, como os diretores de ensino, os inspetores escolares, secretários do Interior, os prefeitos das localidades, vice-presidentes do Estado e professores, ou a algum herói nacional; declamação de poesias pelos alunos, hinos, marchas, passeatas pelas cidades, sessões literárias e apresentação dos escoteiros, especialmente nas festas cívicas e hasteamento do pavilhão.

Nesse mesmo exemplar do periódico ainda foram publicadas diversas fotografias de escoteiros nas comemorações do centenário da Independência. Na época, o escotismo tornou-se uma das atividades preferidas dos filhos das classes médias urbanas, constituindo-se prática distintiva dessa camada social. O governo paulista utilizou-se de diversos instrumentos para valorizar essa instituição, notadamente dandolhe destaque em desfiles oficiais, não somente nos escolares. A prática do escotismo estava associada à disseminação de determinados comportamentos, como obediência incondicional às autoridades constituídas e à hierarquia social. As impressões acerca desse festejo, bem como a transcrição do programa, foram registradas nas páginas do Anuário de Ensino do Estado de São Paulo de 1922:

Após as festas cívicas com que celebramos o primeiro centenário de nossa emancipação política, primeira vitória da nacionalidade brasileira no terreno da democracia, demonstremos ainda no ano do centenário da Independência, nosso ardente amor à forma de governo republicano, a única capaz de conduzir o Brasil aos altos destinos que lhe estão reservado na vida das nações, e o Pavilhão do Cruzeiro, emblema das aspirações democráticas de nossa nacionalidade (Anuário de Ensino do Estado de São Paulo, 1922, p. 353-354).

A programação do evento contou com a participação de, aproximadamente, 12

\footnotetext{
${ }^{101}$ No caso das homenagens, é importante salientar que existiam as festas dedicadas exclusivamente a algum benemérito do ensino e as que se referiam a um tema, mas que previam em sua programação o momento de homenagem às pessoas ilustres presentes. Não foi possível saber, a partir dos artigos analisados, se a presença das autoridades educacionais era previamente acordada e, por este motivo, em todas as festas os alunos deveriam estar preparados para as homenagens, independente do indivíduo a ser homenageado estar presente ou não.
} 
mil escoteiros que "formaram no Ypiranga", constituindo-se, na opinião dos contemporâneos, "um dos elementos mais notáveis dentre todos os que na solenidade comemorativa do Centenário concorreram para emocionar os espectadores da grande festa" que passou, "de hoje em diante, para a lista dos fatos históricos da nossa terra" (Anuário de Ensino do Estado de São Paulo de 1922, p. 301-302). Nas páginas do Correio Paulistano, transcritas no mesmo exemplar dos Anuários, foram destacados o entusiasmo e o brilhantismo da solenidade, na qual os escoteiros escolares tomaram parte significativa, emprestando à comemoração "esse cunho de sinceridade comovedora que é a alegria sadia da criança" (idem). Ocorreram, em todas as regiões de ensino, "concentrações preparatórias nas quais se reuniram cerca de 100.000 escoteiros escolares (...)” (Anuário de Ensino do Estado de São Paulo de 1922, p. 301-302).

As referências a essas festas geralmente apresentavam comentários elogiosos, costumava-se enfatizar a boa organização do programa da mesma, quase sempre composto de hinos, comédias, cantos e poesias aprendidos pelos alunos nas aulas dessas disciplinas no decorrer do ano letivo. Complementando as informações sobre os festejos, os periódicos, muitas vezes, encarregavam-se da transcrição de comédias, cantos, poemas e poesias na seção de Literatura a serem utilizados nessas datas especiais. Outras publicações do período também se dedicaram a apresentação de pequenos textos, poesias, poemas a serem recitados por alunos nas datas comemorativas, como os livros de Carlos A. Gomes Cardim (1916), e de Antonio Pedro Wolff (1918).

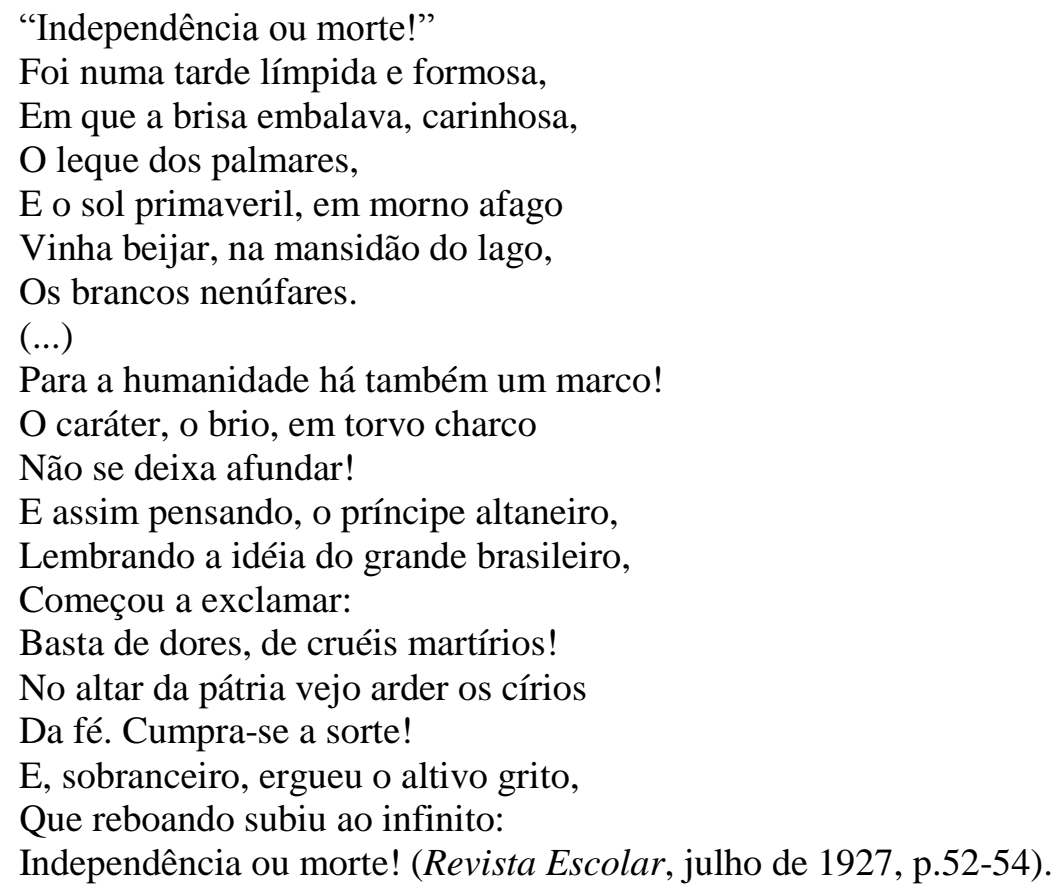


Em seu livro As Comemorações Cívicas e As Festas Escolares, Cardim (1916) assinalava, como exemplo de organização dos festejos escolares a ser seguido por todas as outras escolas do sistema escolar paulistano, a comemoração realizada na Escola Modelo "Caetano de Campos". Nessa escola, as comemorações cívicas foram organizadas da seguinte maneira: o professor reuniu seus melhores alunos para decorarem a sala, dando-lhe um aspecto festivo; além disso, ele preparou um programa a ser executado no dia da festa, que esteve dividido em duas partes: a primeira, a ser iniciada por uma explicação clara e precisa do docente sobre a data, seguindo-se a essa lição, de uma seção cívica composta de trechos alusivos, poesias, pequenos discursos, monólogos, diálogos e comédias, intercalando-se esses trabalhos de declamação com hinos e cantos patrióticos; a segunda parte foi compreendida por um trabalho escrito, em papel próprio, tendo uma gravura que sintetizava a festa. Os alunos, conforme a classe em que se achavam, copiavam trechos, escreviam ditados e faziam composições livres sobre o assunto da data nacional (CARDIM, 1916). Este exemplo, segundo o autor, deveria ser seguido por todos os estabelecimentos de ensino em São Paulo.

$\mathrm{O}$ artigo intitulado Itapetininga, publicado em A Eschola Publica, em 15 de junho de 1896, apresentou uma breve notícia da realização da festa de 13 de maio, relativa à comemoração da fraternidade entre os brasileiros, na escola modelo daquela localidade. No sistema escolar que estava se configurando, as escolas-modelo exerciam uma grande influência para as outras instituições de ensino; elas deveriam ser, como o próprio nome diz, o modelo a ser seguido pelas outras escolas, o foco irradiador das idéias e a responsável pela garantia da uniformidade dos grupos escolares e das escolas isoladas. No artigo Pindamonhangaba, publicado na mesma revista, tem-se notícia da comemoração do dia 15 de novembro pelo grupo escolar Dr. Alfredo Pujol:

No dia 15 de novembro o Grupo Escolar 'Alfredo Pujol' realizou no teatro daquela cidade uma esplêndida festa a que concorreu a maioria da população que sabe apreciar os notáveis progressos que se tem manifestado no ensino público primário. A festa constou de comédias, cantos, poesias, etc.

E o digno diretor que soube preparar e ensaiar as diversas partes do programa, sem prejuízo das horas do trabalho no grupo, mereceu os elogios de toda a população (A Eschola Publica, 1897, p.360-361).

Naquelas ocasiões, era costume que professores, diretores dos estabelecimentos de ensino ou outras pessoas que ocupavam posições de destaque na hierarquia escolar e 
social, como os prefeitos e inspetores de ensino, proferirem discursos ${ }^{102}$ acerca da data que estava sendo comemorada ou sobre outras questões relacionadas ao ensino. Foi comum encontrar, nos periódicos selecionados para esta investigação, somente os discursos pronunciados nas ocasiões festivas, com apenas uma pequena ou nenhuma referência ao momento no qual foi proferido. Considerando esta configuração, pode-se inferir que esses discursos eram tão ou mais importantes do que os outros momentos que compunham as celebrações, como a recitação de poesias, os cânticos, as encenações, a distribuição de prêmios, entre outros. Faz-se pertinente ressaltar que nem sempre o conteúdo daqueles discursos tratava do mote da festa, mas de outras questões relativas ao ensino e que estavam na ordem do dia; sendo assim, ocasiões como formaturas, inaugurações de prédios escolares e aniversários de escolas também se constituíram momentos profícuos para tratar do tema civismo, como ficou registrado no discurso proferido por ocasião da formatura dos alunos do curso secundário no ano de 1913:

(...) Essa comemoração não pode evidentemente limitar-se às simples narrativas, por mais pormenorizada que ela seja. Tratando-se de alunos de um curso secundário, de uma classe de futuros preceptores, é indispensável que façamos aqui aplicação das leis da filiação histórica, isto é, que de fato remontemos às suas causas mais ou menos complexas, para em seguida apreciá-lo nos seus resultados e, sobretudo nos ensinamentos cívicos que ele comporta. Sim, o descobrimento de Brazil (sic) não pode e não deve ser estudado como um fato isolado. Ele constitui efetivamente um episódio inseparável dessa imortal epopéia marítima realizada pelos portugueses durante o século XV e parte do século XVI (Revista de Ensino, junho de 1913, p.21).

Apresentados esses argumentos, o autor se propôs a contar toda a epopéia que culminou com o descobrimento do Brasil e de outros países do hemisfério sul. Por fim, o Professor Rodrigues concluiu sua fala, afirmando que "uma comemoração cívica não tem valor e alcance moral senão quando opera a ligação entre o passado e o futuro" (idem, p.31), para ele, a cultura cívica se reduz ao duplo desideratum: "conhecer a pátria para bem amá-la e amá-la para bem servi-la” (Revista de Ensino, junho de 1913, p.31).. Para isto, os alunos devem ter um conhecimento claro, nítido e ordenado do acontecimento, pois "conhecer a Pátria é conhecer aqueles que combateram por ela" (ibidem).

A seleção dos artigos cuja temática foi o civismo indicou que tal conteúdo

\footnotetext{
${ }^{102}$ Por discursos, entendemos aqui palestras e conferências.
} 
permeou várias práticas escolares do período, tanto das escolas brasileiras quanto portuguesas, não se limitando somente às datas comemorativas, mas fazendo parte de um conjunto amplo de atividade que se tornara componente das rotinas das escolas públicas a partir daquele momento histórico em diante. Como exemplos, lembramos o hasteamento da bandeira e a execução do hino nacional. No caso do civismo, as comemorações serviram para retomar e organizar estes ensinamentos para os alunos e para todo o povo, que deveriam aprender com elas como se tornarem bons cidadãos. Ao retomarem homens e fatos importantes da história dos dois países, atribuía-lhes novos significados e simbolismos. As comemorações cívicas, consideradas com mais ênfase no período de transição dos regimes políticos ${ }^{103}$, serviram para a constituição, não somente da cultura escolar do período, mas da divulgação de uma mensagem política e social associada aos preceitos ideológicos da república.

\section{3 - A personificação do civismo e o caso das homenagens}

As homenagens realizadas tanto no contexto escolar português quanto no brasileiro, tinham como objetivo dar visibilidade aos 'grandes homens' e 'heróis' da história pátria, como exemplos e modelos de conduta social e moral a serem seguidos pelos cidadãos. A escolha das personalidades se baseou na ideia iluminista do grande homem ou mulher que se destacou pelo seu talento e/ou virtudes; de forma metafórica, tratava-se da figura individual do herói salvador da nova "religião da humanidade" (PINTASSILGO,1998, p. 165). O grande homem dos contextos analisados não era a figura

\footnotetext{
103 As notícias sobre as festas cívicas, publicadas nas revistas de ensino, receberam mais atenção em determinados períodos do que em outros. Por exemplo, no primeiro decênio republicano brasileiro, representado neste trabalho pela revista A Eschola Publica, não foram recorrentes as referências sobre as festas cívicas; naquele momento buscava-se enfatizar as festas que davam visibilidade à nova organização do ensino. De 13 artigos selecionados, somente três, desse periódico, referiam-se às festas cívicas ocorridas em outras cidades do estado de São Paulo. Já nos Anuários de Ensino do Estado de São Paulo (1907-1927), foram localizadas 12 referências às festas realizadas nas escolas públicas paulistas. Ao contrário do que ocorreu com os periódicos A Eschola Publica (1893-1897), e Revista de Ensino (19021918), nos quais prevaleceram artigos acerca das festas de fundação, aniversário das escolas e encerramento do ano letivo, nos Anuários (1907-1926), destacaram-se as alusões feitas às festas cívicas. Percebe-se, nos textos selecionados dos Anuários de Ensino do Estado de São Paulo, mais do que nos outros periódicos citados, a predominância de um tom prescritivo, presente tanto nas circulares enviadas aos senhores delegados regionais, dando indicações de como deveriam ser comemoradas determinadas datas, quanto nos relatórios dos inspetores, apresentando como estava a educação em determinada localidade e as soluções para os possíveis problemas educacionais e também na legislação educacional transcrita. Faz-se relevante assinalar esta diferença, já que os Anuários de Ensino do Estado de São Paulo eram um órgão oficial de divulgação das realizações da Inspetoria Geral de Ensino e expressavam a opinião oficial acerca das questões educacionais.
} 
do herói isolado, característico do romantismo, mas sim um 'homem representativo', uma figura que deveria encarnar as qualidades constitutivas da Nação, o arquétipo das aspirações e dos valores coletivos. Na perspectiva do positivismo, os heróis deveriam ser figuras que, pelas suas características reais ou imaginadas, poderiam ser apresentados como modelos às crianças e jovens, permitindo identificar-se com estes. Não foi sem motivo que muitos manuais e periódicos do período traziam uma "galeria dos homens ilustres" ou "panteões escolares" "104, cujo intuito pedagógico e cívico era incorporar na consciência dos futuros cidadãos a sua exemplaridade, não como um apelo regressivo, mas como crença na viabilidade futura da nação (CATROGA, 2000; $2005)^{105}$.

Em Portugal, as primeiras iniciativas registradas no corpus analisado ocorreram ainda no período monárquico, sob a responsabilidade dos partidários do republicanismo. A primeira ocasião deu-se pela comemoração do terceiro centenário da morte de Camões (1880), a qual se seguiram outras, com destaque para homenagens a Marquês de Pombal em 1882; Alexandre Herculano, em 1888 e 1910; Almeida Garret, 1899; João de Deus, 1896 e Antonio Feliciano de Castilho, em 1900 (PINTASsILGO, 1998); já na literatura escolar ainda ganharam destaque: Nuno Álvares Pereira, símbolo da Independência e o Infante D. Henrique, representativo do período histórico da expansão ultramarina portuguesa. No Brasil, destacaram-se a comemoração do Centenário da Independência, em 1922 e as homenagens realizadas a Olavo Bilac, Tiradentes, D. Pedro I e José Bonifácio, entre outros.

Nas instituições de ensino, os cultos aos grandes nomes das nações portuguesas e brasileiras contavam com estratégias, como a colocação de cartazes elaborados pelos alunos sob a supervisão dos seus mestres, inauguração de bustos nas classes ou nos pátios, nas lições morais e cívicas retiradas dos textos dos periódicos e dos manuais de ensino pelos professores e que recuperavam a história de vida e os grandes feitos de tais homenageados e, também, de forma mais expressiva, nas comemorações escolares.

Além das solenidades dedicadas aos nomes representativos das histórias nacionais dos dois países, utilizou-se como estratégia para tornar mais próxima e

\footnotetext{
${ }^{104}$ Este foi o título dado à seção das homenagens feitas às personalidades ilustres na Revista de Ensino do Estado de São Paulo.

${ }^{105}$ As práticas associadas ao culto dos grandes homens foi engendrada no contexto de implementação da terceira república francesa que, pela via do positivismo, colocou exemplarmente essas práticas em funcionamento, em íntima conexão com o nacionalismo exaltado. Nomes significativos para a constituição histórica do país foram recuperados e solenizados com rituais bastantes elaborados; esses foram os casos de Voltaire e Rousseau, no ano de 1878 e Vitor Hugo, em 1885 (PINTASSILGO, 1998).
} 
presente os ideais cívicos da população, uma série de homenagens a pessoas comuns, pouco conhecidas nacionalmente, mas que poderiam representar para os indivíduos de uma localidade específica, o ideal de cidadão que se almejava atingir. Nesse sentido, faz-se relevante destacar, especialmente no caso português, as recorrentes homenagens feitas aos professores, diretores e inspetores de ensino, como por exemplo, a realizada em 26 de janeiro de 1928, na escola de Vila Franca ao professor Francisco Câncio.

Uma homenagem bastante oportuna, nas palavras da Revista A Escola Primária, realizada em um contexto no qual sobre o professor primário "desabam tantas desditas, tantas ingratidões", foi consolador registrar a homenagem "de respeito e gratidão que alguns antigos alunos prestam a seus velhos mestres, sirva-nos ao menos a gratidão de alguns, para suavizar as feridas morais, produzidas pelo desprezo de muitos" (A Escola Primária, 26 de janeiro de 1928, p. 02). Em Guimarães, os alunos do estimado professor José Maria Felix também realizaram uma homenagem "muito carinhosa" aos 42 anos de "bom serviço" do distinto mestre. Além da entrega da mensagem, dos discursos e das palavras lisonjeiras, os alunos:

- levaram-lhe também, como lenititivo para o resto dos seus dias, uma caderneta de depósito à ordem, na importância de vinte e três mil escudos!

Gente previdente, sem dúvida, esta de Guimarães que, talvez por bem saber que o Estado nem sempre dispensa aos Mestres, na velhice, aquele merecido auxílio que a sã justiça impõe, quis, de permeio com muitas palavras carinhosas, contemplar o seu grande amigo com um presente, capaz de lhe minorar possíveis privações na velhice $(A$ Escola Primária, 26 de janeiro de 1928, p. 01).

As homenagens dedicadas aos diferentes profissionais da área educacional visaram reconhecer nestes indivíduos a importância social da suas atuações, retribuírem simbolicamente os seus serviços, assim como minimizarem o débito material para com estes profissionais. Indicando em seus programas momentos específicos, particularmente nos discursos proferidos, para o reconhecimento e exaltação das características morais e profissionais ideais aos professores, contribuíram de forma inequívoca para a constituição das suas identidades docentes.

Não somente os mestres foram homenageados. No ano de 1929, ocorreu na Vila do Conde, em Portugal, uma homenagem organizada pelos professores da região ao "ilustre inspetor", o Senhor Padre Agostinho Antunes de Azevedo, "como manifestação de simpatia e reconhecimento, ante as suas belas qualidades morais e intelectuais de orientador", e ao mesmo tempo, "de pesar, pela deslocação a que se vê obrigado, por efeito da nova remodelação do inspetorado" (A Escola Primária, 19 de 
janeiro de 1929, p. 104). A homenagem consistiu numa sessão solene com a presença dos alunos, mestres e outros dirigentes educacionais, em que foi oferecida ao Senhor Inspetor, uma artística salva de prata, tendo sido tirada, no final da sessão, uma fotografia em um grupo do inspetor com todos os docentes, como forma de registro da passagem e dos trabalhos realizados por aquele profissional na região (idem).

Diversos fatos relacionados à vida profissional e pessoal dos mestres poderiam se tornar ocasiões de homenagens. Seus aniversários de nascimento e de entrada na profissão, as transferências e promoções para outras localidades, as festas de encerramento dos anos letivos (aqui teríamos homenagens dentro de outra festa), assim como o momento da aposentadoria, considerado a consagração de uma carreira. Os ritos poderiam ser mais simples, com discursos e a entrega de insígnias, ou mais elaborados e divididos em uma ou mais partes, como foi o caso da aposentadoria do diretor da Casa Pia de Lisboa, Sr. Alfredo Soares. Naquela oportunidade, foi entregue ao diretor as insígnias da Ordem de Benemerência e Instrução pelo Senhor Ministro da Instrução, com a assistência dos srs. Ministros do Interior e Instrução, muitos amigos do Sr. Alfredo Soares e algumas centenas de ex-alunos com suas famílias, além dos atuais alunos, todos presentes na Sala Portugal. A celebração estendeu-se ao período da noite, com o oferecimento de um banquete no Francfort Hotel e os discursos de vários amigos e admiradores, que puseram em destaque a obra eminentemente educativa que aquele diretor realizara na Casa Pia de Lisboa (A Escola Primária, 17 de janeiro de 1929, p. 113).

No mesmo ano, no mês de julho, noticiou-se na mesma Casa Pia, outra festa realizada em homenagem à aposentadoria do Professor Eduardo Augusto da Silva. Neste caso, a festa mais simples visou ressaltar os quarenta anos de exercício do ensino naquela mesma instituição e as características exemplares do mestre. $\mathrm{Na}$ ocasião, discursou o colega professor e representante da revista A Escola Primária, o Sr. José da Cruz Filipe que, numa síntese admirável, evidenciou as "altas e raras qualidades artísticas do homenageado" que foi professor de alguns dos "primeiros artistas na pintura, na arquitetura e escultura" do país e que, sendo uma "glória e exemplo vivo dos admiráveis processos e métodos de ensino deste estabelecimento, constituem já hoje também verdadeiros valores nacionais" (A Escola Primária, 11 de julho de 1929, p. 360). Ao fim dos discursos, a numerosa assistência aplaudiu com uma "quente salva de palmas" e foi entregue pelo Sr. Diretor Geral da Assistência uma linda pasta artística, 
escrita, ilustrada e toda feita nas oficinas da Casa Pia, por antigos e novos alunos (idem).

No entanto, nem sempre a presença dos homenageados constituiu-se condição imprescindível para a realização de tais solenidades. O uso de retratos e bustos como representações das personalidades, permitiu que as festas se realizassem sem a presença física dos homenageados. Neste sentido, retomamos a homenagem feita ao $\mathrm{Sr}$. Francisco Alves da Silva por meio da inauguração de um retrato pessoal na escola da Venda Nova, em Portugal, construída com o seu auxílio material. A escola, na opinião dos redatores do periódico, estaria muito bem situada e teria beneficiado uma grande população escolar, pois, no ano letivo que acabara de findar, 1928, foi frequentada por perto de 90 alunos. Uma comissão organizou a festa de inauguração do retrato do benfeitor e, muito antes da hora marcada para a sessão solene, já estava o recinto em volta da escola repleto de povo. Na sala, também cheia, encontravam-se representantes da Comissão Administrativa da Câmara Municipal, da Junta de Freguesia e muitas pessoas de destaque daquela localidade (A Escola Primária, 08 de agosto de 1929, p. 377). Constituiu a mesa sob a presidência do ilustre Inspetor-chefe, o Sr. Joaquim Tomás que, em breves, mas sinceras palavras, enalteceu o significado daquela manifestação depois de ter brilhantemente dissertado sobre as enormes vantagens da instrução. Sr. Joaquim Tomás foi muito aplaudido pelo seu feliz improviso, convidou a irmã do homenageado a descerrar o retrato que estava coberto com a bandeira nacional. Além do Sr. Joaquim Tomás, usou da palavra o professor da Escola Industrial e Comercial de Tomar, Sr. Samuel de Oliveira que, com clareza e muito acerto, se pronunciou pela necessidade cada vez mais urgente de se cuidar, a sério, da instrução do povo. Em seguida, ainda, em nome de A Escola Primária que gentilmente havia sido convidada, falou o professor Cruz Filipe que, verdadeiramente encantado com a festa que estava assistindo, se demorou em considerações sobre o valor da instrução, acentuando bem que era ao professor primário que estaria entregue a maior tarefa da educação do povo, pelo que mereceria o maior respeito e a consideração de todos. $\mathrm{O}$ professor exortou aos pais dos alunos a nunca desviarem os filhos da escola a pretexto de quaisquer serviços que eles lhes possam, porventura, prestar, e frisou que, mais tarde, eles teriam a satisfação de ver seus filhos instruídos e em condições de melhor orientar os trabalhos das terras e de lhes valerem na velhice. Por último, o Sr. Inspetor-chefe entregou, numa bonita moldura, a fotografia da escola à irmã do homenageado, oferta esta que era feita pelos alunos da escola. 'Depois dum 'Porto de Honra' servido aos 
convidados terminou esta linda festa que por muito tempo perdurará no espírito de todos que tiveram o grande prazer de a ela assistir" (idem, p. 377).

É relevante destacar que, apesar de se tratar de uma festa escolar em homenagem a um benfeitor do ensino não se percebeu, na descrição da festa publicada no periódico, a participação dos alunos em nenhuma atividade; até mesmo o oferecimento de uma bebida alcoólica poderia causar estranheza aos leitores do texto e comprovar a impossibilidade da participação de crianças em tal celebração. A presença dos pais fica subentendida na fala do professor Cruz Filipe que se dirige aos mesmos, exortando-os a não retirarem os filhos da escola; apesar disso, os próprios alunos não foram indicados como responsáveis por partes do evento em nenhum momento. Ao contrário da celebração realizada na localidade de Moreiras Grandes, no ano de 1932, por motivo da aposentadoria do professor António Rodrigues Pena, na qual, todo o programa da festa parecia ter sido conduzido pelos alunos, que:

(...) depois de alguns números do programa em que as crianças brilharam pela sua alegria e pela graça com que cantaram e dançaram, principalmente os 'Pregões de Lisboa' e o 'Bailari' foi dada a palavra ao nosso colega..." (...). E depois dum frenético reboar de palmas, ouve-se o orfeão cantar a Portuguesa que é seguida, depois, com vivas à Escola, à República e à Pátria (A Escola Primária, 05 de junho de 1932, p. 78).

Um outro benemérito do ensino reconhecido pelos seus esforços na constituição das escolas portuguesas foi o Conde Ferreira que, no ano de 1930, foi homenageado pelas escolas de Mafra - Portugal. Houve sessões solenes, muitos discursos, "muitas palavras de encher as almas mais vazias de esperanças" (A Escola Primária, 10 de abril de 1930, p. 124). A celebração teria vindo em boa hora, segundo o periódico, pois, semanas atrás, encontraram nos jornais a notícia de a câmara de Mafra ter deliberado demolir uma dessas escolas, por ameaçar ruína. Sendo assim, ainda na opinião do periódico, a melhor homenagem a prestar ao Conde Ferreira estaria em mandar consertar as muitas escolas que ele doou ao Estado, tantas das quais caminham para o triste fim. O aludido periódico mencionava, ao final: "mas que fazer, se as obras são caras e as sessões solenes pouco custam?” (A Escola Primária, 10 de abril de 1930, p. 124). Em mais uma oportunidade, a comemoração tornou-se momento de desabafo e críticas ao governo da região. Percebida como teatro de uma situação específica, em muitos casos, o uso das festas serviu para dissimular o que realmente se vivia naquele contexto. Desse modo, caberia a seguinte distinção entre as festas escolares: as festas 
das crianças, nas quais estas assumem o protagonismo na sua realização e as festas para crianças, preparados por outros para a assistência juvenil.

Como tentativa de valorizar a profissão docente, garantir seu destaque social e demonstrar-lhe "o grande apreço e a mais sincera simpatia pela sua obra educativa" ( $A$ Escola Primária, 20 de abril de 1936, p. 05), bem como amenizar as agruras e desfeitas sentidas pelos mestres, outras instituições sociais tomaram para si a responsabilidade pela organização de cerimônias, como a realizada no Rotary Club de Lisboa, em abril de 1936, para os professores primários. Naquela ocasião, estiveram presentes diversos representantes dos senhores professores do ensino primário das escolas oficiais da Capital, Excelentíssimo Diretor Geral do Ensino Primário, Senhor Dr. Braga Paixão, o Senhor Inspetor orientador e o Senhor Diretor do distrito escolar de Lisboa. Nessa reunião, o presidente do Rotary Club, o Prof. Dr. Queiroz Veloso, deu as boas vindas aos convidados, e fez a palestra regulamentar sobre: "O professor do ensino primário" (p. 04), lembrando que:

Para quem, como os professores primários, passa uma vida, no geral apagada, tão cercada de atribulações, tornam-se altamente consoladoras estas festazinhas do espírito que, sobre muito se refletiram o prestígio da Classe, muito nos retemperam o ânimo para a luta de todos os dias... (A Escola Primária, 20 de abril de 1936, p. 05).

No rol das notícias veiculadas acerca das homenagens dedicadas aos professores, consta uma realizada a uma professora da localidade de Tomar - Portugal, a quem o governo da República havia conferido uma alta distinção pelos trabalhos prestados. A descrição da festa, narrada em tom bastante informal comparada às demais, destacou a grande presença de mulheres, flores e crianças no evento; "De resto, a festa metia mulheres, flores e crianças, e só isso dava assunto para essa coisa banal, corriqueira e desacreditada que se chama discurso" (A Escola Pública, 27 de março de 1930, p. 102), o discurso da homenageada e, por fim, o grande banquete organizado pela professora para os seus convidados. É relevante destacar desta notícia, os elementos presentes na construção do texto e que nos remetem aos historicamente constituídos como referências ao universo feminino: flores, crianças, assuntos corriqueiros e o oferecimento de um lanche, assinalando diferenças quanto aos modos de se homenagear os homens e as mulheres profissionais do ensino:

Bem ou mal, pois, o serviço fez-se, a homenagem prestou-se com certo luzimento; mas, se nos é permitida a franqueza, acrescentaremos que bem mais homenageada foi a assembléia pela professora ilustre, do que esta pelos aplausos do respeitável público. 
Eu me explico: é que, finda a cerimônia do palavriado, a homenageada teve a genial ideia de convidar a assistência para um copo de água- e nós nunca presenciamos maior disparate do que isso de se chamar copo de água a uma coisa que só meteu copos de champagne, com uma grande variedade de doces finos à mistura.

(...)

É possível que o leitor curioso esteja nesta altura ardendo em desejos por saber, tim tim por tim tim, tudo o que de bom na festa se comeu e bebeu; mas nessa é que nós não caímos, pelo receio de, mais podermos irritar ainda contra nós a ferrenha irredutibilidade do Sr. Oliveira Salazar. Podem objetar-nos que é com papas e bolos que se enganam os tolos, mas como o Sr. Ministro das Finanças não usa picar nesses anzóios, mais vale deixá-lo, a ver se de nós se condói, na doce ilusão de que os nossos 'copos de água' voltarão a ser apenas de autêntico $\mathrm{H} 2 \mathrm{O}$, fora de toda a ação das videiras da Anádia e da cana açucarada de Ângola (...). Gil de Oliveira Mendonça (A Escola Pública, 27 de março de 1930, p. 102).

No Brasil, a Revista de Ensino (1902-1918) foi o periódico que mais noticiou celebrações exclusivamente dedicadas às homenagens nas suas páginas: ao todo foram três, nos dezesseis anos de existência da revista, indicando que a prática de realizar homenagens misturou-se a outras solenidades dedicadas a outras temáticas, ou seja, não foi recorrente a criação de momentos específicos, com indicação de datas e programas, às homenagens aos professores, que deveriam ocorrer nas mais diferentes ocasiões festivas. Anteriormente, noticiou-se uma nas páginas do periódico A Eschola Publica, dedicada ao aniversário de nascimento da diretora D. Brazilia no Collegio Andrade, cujo "variadíssimo" programa terminou com "uma imponente soirée oferecida pelos alunos daquele estabelecimento à sua distinta Diretora, que naquele dia completava mais um ano de preciosa existência" (A Eschola Publica, abril de 1894, p.72).

As três homenagens localizadas nas páginas da Revista de Ensino referiram-se, respectivamente, a uma homenagem feita ao "ilustre estadista francês", Sr. Doumer, que havia visitado a Escola Normal paulista em setembro de 1907; outra homenagem póstuma feita ao Sr. Dr. José Estácio de Sá e Benevides, em dezembro de 1914, lente da cadeira de História Universal e do Brasil da Escola Normal da Capital, que havia falecido há poucos dias, e a terceira, feita ao poeta Olavo Bilac, "insigne artista de 'Via Láctea"”, acontecida em dezembro de 1917. A homenagem feita para o Sr. Dr. José Estácio de Sá e Benevides foi organizada pelos alunos e professores associados ao Grêmio Normalista "Dois de Agosto", da Escola Normal de São Paulo. Desse evento, participaram todos os lentes e professores da Escola Normal, discípulos de todos os cursos daquele estabelecimento e admiradores do antigo mestre. A família do homenageado se fez representar pelo Sr. Dr. Gabriel de Rezende, senador estadual e 
lente da Faculdade de Direito de São Paulo. O programa foi organizado da seguinte forma: I - Abertura da sessão pelo Sr. José C. de Almeida, presidente do Grêmio Normalista "Dois de Agosto"; II - Canto de Mendelsohn; III - Discurso do lente Sr. João L. Rodrigues (que foi transcrito na íntegra); IV - Discurso do orador do Grêmio, Sr. Euclydes de Lima; V - Discurso do orador Dr. Leopoldo Sant'Anna, lente da escola Normal Primária e, por fim, uma apresentação musical, VI - Lefevre - Harmonia Coral (Revista de Ensino, dezembro de 1914, p. 46).

A homenagem feita à Olavo Bilac também teve como sede a Escola Normal da capital de São Paulo e, segundo o autor responsável pela escrita do artigo, foi uma "festa encantadora", que permaneceria na memória daqueles que estavam presentes durante em bom tempo. O programa constou de coros executados pelos alunos, recitação dos versos de Bilac e discursos do Dr. Sampaio Doria e do estudante Fausto Rocha, que foram transcritos no exemplar da revista após a apresentação do programa, que:

(...) executado a rigor, agradou sobremodo, despertando na brilhante assembléia uma viva demonstração de alegria. Empolgaram-na, arrebataram-na a harmonia dos coros executados pelos alunos do importante estabelecimento, a eloquiência vibrante dos oradores, o calor mágico dos versos de Bilac (Revista de Ensino, dezembro de 1917, p. 67).

Ao lado dos grandes nomes da história, dignos de figurarem na memória histórica e coletiva da população brasileira e portuguesa, dos primeiros reformadores das escolas públicas paulistas, dos professores, inspetores e diretores cujos trabalhos realizados se destacaram, figuraram ainda nas homenagens, o nome de um aluno cujo ato de coragem e de nacionalismo tornou-se digno de ser solenizado. Este foi o caso da homenagem realizada ao estudante Antonio Chagas, por ocasião da festa da bandeira, no ano de 1916. O discurso do educador Coelho Neto proferido nessa ocasião, relatou detalhadamente o episódio no qual Antonio Chagas, em meio a um naufrágio, voltou ao barco que estava afundando e salvou o estandarte brasileiro. Este ato foi considerado como um exemplo de amor à pátria, que deveria ser perpetuado e seguido por todos os outros alunos presentes, e também às pessoas mais velhas (mestres e pais que se encontravam na solenidade). Na ocasião, o autor de tal feito, Antonio Chagas, foi premiado com uma medalha e muito ovacionado pelos presentes.

Imponente, de uma imponência augusta foram as festas realizadas no - Dia da Bandeira.

Em São Paulo, no Rio de Janeiro, em todo o Brasil, a comemoração do dia 19 de novembro teve grande brilho e realce. 
O sentimento pátrio vibrou talvez ainda mais fortemente agitado pelo rasgo sublime de uma criança (Revista de Ensino, março de 1916, p. 19-22, grifo nosso).

As solenidades realizadas como forma de homenagear os heróis nacionais, os professores, os diretores, os inspetores de ensino, os alunos, tanto das escolas públicas portuguesas quanto brasileiras assinalaram esforços no sentido de consolidar as memórias históricas de Brasil e Portugal, recuperando fatos e personalidades históricas relevantes política e socialmente para os países investigados, bem como o de disseminar o ideal de cidadão e profissional a ser perseguido nas distintas realidades. Seja por meio de exemplos mais distantes, Marquês de Pombal ou Tiradentes, para citar personagens dos dois países, ou pelos modelos mais próximos, como os professores das escolas primárias, a recuperação das qualidades morais de tais indivíduos visou inspirar as ações e pensamentos das novas gerações. Celebrando as diferentes etapas, momentos da vida ou ações dos homenageados, estas festas constituíram-se, também, em momentos para denunciar as falhas dos sistemas de ensino, especialmente no que dizia respeito ao tratamento dado aos mestres e as condições de funcionamento das escolas, tentando, a partir disso, recuperar, ao menos simbolicamente, a relevância social dessa categoria profissional e da educação.

\section{4 - A pátria representada por símbolos: as festas da bandeira}

A festa da bandeira ${ }^{106}$ foi considerada pelos propagandistas da República o símbolo máximo da pátria. O culto do pavilhão configurou-se como a expressão estética mais totêmica do simbolismo nacional e, desde cedo, a criação de um dia para a sua comemoração foi atrelada a sua condição de mobilizar emocionalmente as crianças (CATroga, 2005). Tal solenidade foi comemorada pela primeira vez em 1906, na Escola Normal de São Paulo, de acordo com João Lourenço Rodrigues (1907-1908), em relatório apresentado ao Exmo. Snr. Secretário dos Negócios do Interior nos Anuários de Ensino do Estado de São Paulo. Essa festa foi considerada uma instituição cívica

\footnotetext{
${ }^{106}$ Em 1889, foi decretado pelo Governo Provisório, o modelo atual de Bandeira da República, concebida como símbolo de amor e simpatia pela pátria, que deveria ser respeitada e adorada. Assim como nos Estados Unidos, Suíça e Bélgica, o Brasil fulgurava como um país que adotava a bandeira como a manifestação mais formosa e mais perfeita do patriotismo. Esses países, que traziam a instituição escolar em mais alto grau, converteram a festa da Bandeira em tradição destinada a criar, nas crianças, o amor pelo pavilhão nacional e reconhecê-lo onde quer que ele esteja.
} 
simbolicamente rica, já que deveria ser capaz de, desde cedo, familiarizar as crianças com a idéia de pátria por percepções sensíveis, "entoando hinos patrióticos diante da bandeira que flutua diariamente no alto do edifício escolar" (Anuários de Ensino do Estado de São Paulo em 1907-1908, p. 66). Para João Lourenço Rodrigues, era desejável que essa solenidade tivesse início naquela data e continuasse em todas as nossas escolas, pois "como ensinamento cívico, supera em resultado as inoportunas e abstratas divagações até onde não chega a inteligência infantil” (idem). E sugeria ainda que, em cada sala de aula e prédio escolar, fosse colocada uma bandeira em lugar bem visível para que os alunos pudessem cultuá-la todos os dias letivos na abertura dos trabalhos escolares e não só no dia reservado à sua comemoração, com exceção das escolas isoladas, cujo hasteamento, como o hino da bandeira somente deveriam ser promovidos nos feriados (Revista Escolar, outubro de 1925, p. 28-31).

Com o costumário brilho dos anos anteriores, realizou-se a 19 do mês p. findo, a cerimônia da "Festa da Bandeira", nas escolas-isoladas, grupos escolares, escolas-modelo e outros estabelecimentos de ensino do Estado. Os alunos ouviram úteis preleções sobre a grande data nacional e muito a homenagearam com recitativos, cantos, poesias e jogos escolares. À festa, no Jardim da Infância, esteve presente o Sr. Dr. Secretário do Interior, que dali saiu agradavelmente impressionado (Revista Escolar, dezembro de 1925, p.103).

O exemplo da festa da bandeira realizada na Escola Normal de São Paulo, por iniciativa de João Lourenço Rodrigues, serviu de modelo e inspiração ao Sr. Dr. Oscar Thompson e ao professor e inspetor das escolas anexas, Carlos Gomes Cardim, como constou em artigo publicado na Revista de Ensino de novembro de 1907. Foi a primeira festa da bandeira realizada nessas escolas, que deveriam servir de paradigma para as outras escolas (grupos escolares, escolas isoladas e escolas reunidas). Do relato publicado constou que, neste dia todas as classes tanto da seção feminina, quando da seção masculina, revestiram-se de um aspecto "alegre e festivo"; a ornamentação de cada sala ficou a cargo de uma comissão de alunos eleita no princípio do ano e fiscalizada pelo respectivo professor. Cada sala de aula tinha desenhado em seus quadros negros, com giz coloridos, os dois estandartes do Brasil: o do período monárquico e do período republicano. O lugar central em todas as salas e na escola era ocupado pela a Bandeira Nacional, tal "qual um ídolo no altar" (Revista de Ensino, novembro de 1907 , p. 85-87). 


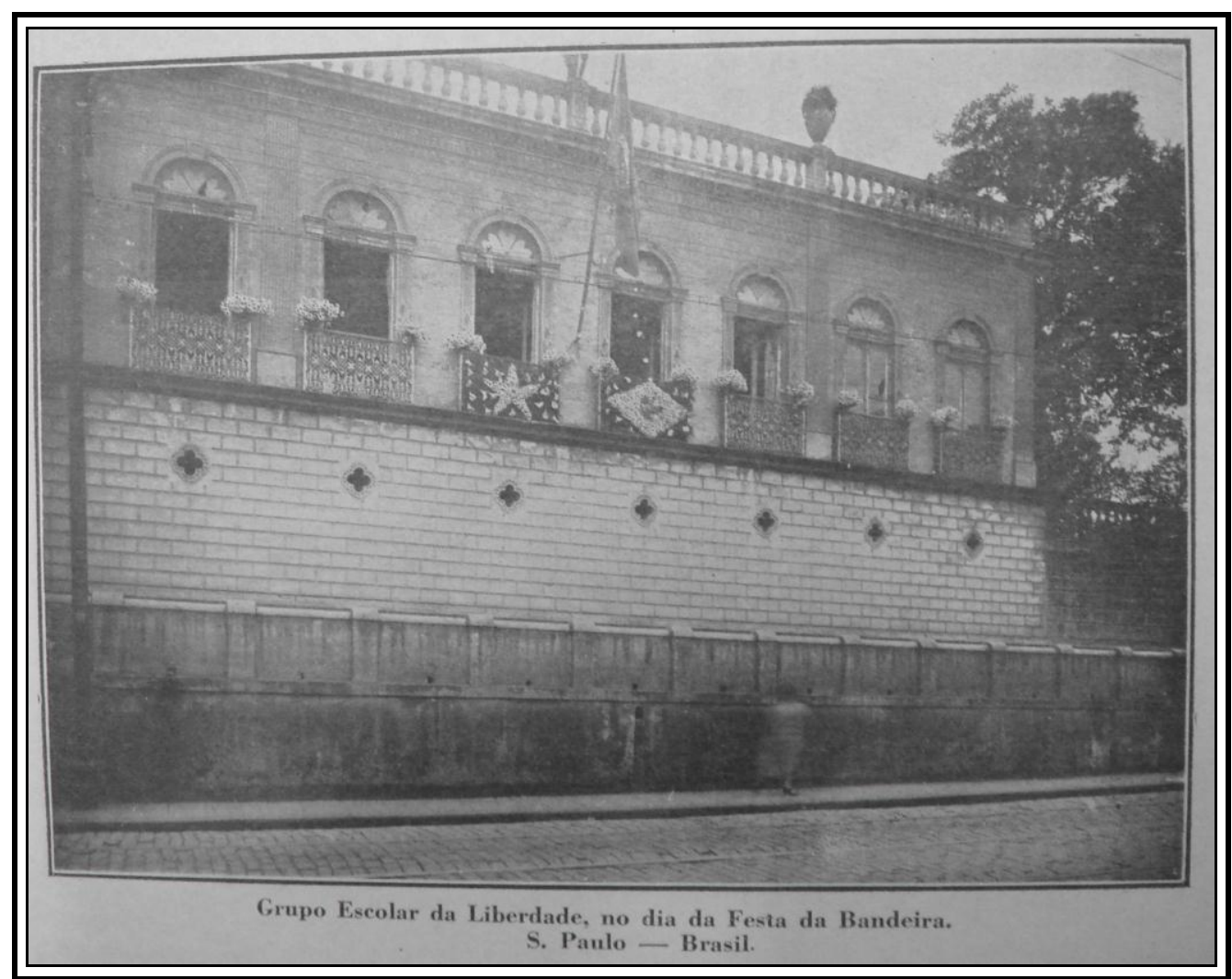

Escola enfeitada para a Festa da Bandeira- Grupo Escolar da Liberdade Revista Escolar, jan 1927, p. 49.

Conforme informações do artigo, a data foi comemorada de forma distinta pelos alunos e professores, de acordo com o nível de conhecimento de cada classe. No primeiro ano, por exemplo, no qual as crianças começavam os primeiros ensinamentos escolares, cada aluno deveria recitar um trecho referente à data de 19 de novembro. No segundo ano, os alunos fizeram cópias de fragmentos de textos concernentes à história da bandeira ou referente à escolha do dia 19 de novembro. No segundo ano suplementar, também houve cópia de composições referentes à data. No terceiro ano, o professor fez um ditado de um capítulo sobre o pavilhão nacional. No quarto ano, a "comemoração escrita" foi uma reprodução individual dos discursos dos professores. No curso complementar, os alunos não se limitaram a reproduzir explicações que ouviram; alguns fizeram pesquisas e "discorreram eloqüentemente" sobre o tema do dia. Em todas as classes, a "produção escrita", concebida como o momento no qual a comemoração assume um caráter escolarizado e mescla-se aos métodos escolares, constituiu-se a segunda parte do programa, organizado da seguinte forma (Revista de Ensino, novembro de 1907, p. 89):

A primeira parte do programa era entrecortada de poesias e páginas patrióticas, como - Minha Terra, A S. Paulo, Pátria Livre, Ao Brasil, 
Sete de Setembro, O Suplício de Tiradentes, A República, Um Episódio da Guerra do Paraguai, etc e amenizada por cânticos harmoniosos ou salmos em louvor às nossas glórias e datas. (...) Em cada sala, os alunos, ao som de Hynno à Bandeira, desfilavam pela frente ou ao redor do pavilhão, jogando-lhe flores. Faziam-lhe, ao mesmo tempo, continência e saudação (Revista de Ensino de novembro de 1907, p. 89-90).

Em Portugal, o culto à bandeira permeou diferentes comemorações escolares, nas quais os alunos foram chamados a reverenciá-la por meio do hino A Portuguesa, de continências ou ainda empunhando-a em desfiles patrióticos. Em diferentes situações como nas homenagens, nas inaugurações de escolas ou de dependências escolares (bibliotecas, cantinas), ou nas festas das árvores, a bandeira portuguesa recebeu um lugar de destaque assinalando todo o simbolismo que aquele objeto representava:

\begin{abstract}
Seguiu-se o cortejo cívico composto dos alunos militarmente formados com a bandeira nacional à frente, comissão, convidados, e de três carros alegóricos representando a agricultura, a indústria e o comércio, vistosa e artisticamente enfeitados, cujo delicado trabalho se deve aos cuidados dos prestáveis cidadãos António F. Carreira, António dos Santos e Augusto Roque, principalmente.

O cortejo era fechado pela filarmônica seguida de extraordinária quantidade de povo, dirigiu-se para o local onde havia de fazer-se a plantação das árvores (O Magistério, julho de 1914, p. 03).
\end{abstract}

A festa da bandeira, além da referência ao patriotismo que deveria compor o imaginário social das populações dos dois países, pelo dia escolhido e pela proximidade das férias escolares no Brasil, indicou para os alunos e professores o prenúncio do final do ciclo anual da escola. Comemorada no mês de novembro, era o momento no qual se apuravam "os conhecimentos adquiridos, recompensando os esforços dos que foram cumpridores de seus deveres e condenando a negligência dos que deixaram correr desaproveitado o tempo" (Revista de Ensino, novembro de 1907, p. 88). Era um mês de exame de consciência, no qual os alunos que estudaram e tiveram bom aproveitamento eram louvados, e os outros, que se deixaram levar pelas brincadeiras e ilusões, amargavam a penalidade por sua própria culpa: "O mês de novembro é o mês das sínteses para quem estuda e para quem ensina" (Revista de Ensino, novembro de 1907, p. 88).

Apesar dos dirigentes selecionarem e detalharem de forma precisa como os dias cívicos deveriam ser comemorados, propondo, por meio desses, a naturalização do imaginário político republicano, foi possível notar, a partir dos textos selecionados para o estudo, especialmente os considerados autobiográficos indicados nos romances do capítulo anterior, que os objetivos destas festas cívicas ficaram obscurecidos em alguns 
momentos por outras funções assumidas pelas festas, como a exposição do status social da instituição escolar e do seu diretor, pela arrecadação de dinheiro para ornamentar da melhor maneira possível as escolas e pelo cumprimento simples e sem emoção de determinações legais, perdendo-se, desse modo, o objetivo primeiro, almejado pelos dirigentes da festividade, que era despertar o sentimento do patriotismo e do civismo. Esses diferentes sentidos atribuídos a um mesmo tipo de festejo, no caso a festa cívica, demonstraram que as "apropriações" que são feitas das festas podem extrapolar os desígnios propostos para a mesma, e não podem ser desconsiderados.

\section{5 - As festas beneficentes: entre a moral cristã e a escolar}

As comemorações escolares organizadas nesta categoria possuíram, como característica distintiva, o forte apelo às ações de doação às escolas e aos estudantes, bem como a arrecadação e provisão de recursos materiais para o bom andamento do ensino. Ao lado dos valores cívicos associados às nações e aos regimes políticos que se legitimaram, as instituições de ensino assumiram para si, neste contexto, a responsabilidade pela formação de valores; dentre eles, alguns considerados cristãos, como a beneficência e a caridade. No caso das festividades escolares, a prática da caridade, presente no discurso religioso, tornou-se elemento fundamental para a configuração de dispositivos políticos quando confirmou a solidariedade presente como valor nos discursos, em altruísmo nos discursos psicológicos, garantindo, em todos os âmbitos, o seu sentido de doação (SILVA, 2011). É importante assinalar que a realização deste tipo de comemoração não aconteceu da mesma forma na realidade brasileira e portuguesa, mas notaram-se de forma recorrente, notícias deste tipo de festejo escolar nos periódicos de ensino portugueses que, em diferentes situações, como na época do Natal ou no então criado, "Dia da Bondade", conclamavam a população escolar e o público em geral ao ato da doação para a "grande causa" da educação. No caso brasileiro, tivemos algumas menções a esse tipo de festa; entretanto, a ideia de caridade e/ou beneficência aparecia de forma pulverizada em festejos que possuíam outros motes, e não de forma tão direta e explícita, como foi o caso das solenidades portuguesas. 
A presença de ações, como a doação, e a valorização de sentimentos, como a caridade e a solidariedade em um projeto considerado civilizador das instituições de ensino, indicaram os modos pelos quais a escola criou e recriou os significados culturais de determinadas práticas por meio de estratégias de apropriação específicas e que carregara as marcas do seu projeto (ВотО, 2010). As escolas instituíram, por seus ritos, por suas palavras e por seus sinais, uma cultura que lhe foi própria e que, em última instância, ao remodelar os comportamentos, atuou na formação do caráter e também das almas, por meio de uma minuciosa disciplina do corpo e direção das consciências (JULIA, 2001). O projeto das instituições de ensino consideradas modernas e civilizadoras deveriam formar o caráter e a alma, situação que poderia ser considerada ambígua por alguns, apareceu de forma bastante conciliatória nas festas escolares beneficentes, que tratou dessa temática nos seus rituais de forma bastante "natural""

Para os educadores da época, tão importante quanto ensinar as primeiras letras e as operações matemáticas, foi investir na moralização como pré-requisito ao progresso da civilização. A lei moral seria então, para o sujeito racional e autônomo, um mandamento incondicional, um imperativo universal do dever; e deste, por sua vez, decorreria, necessariamente, a ação prática (ВОTO, 2004). O conceito e a ação se completariam e aí estaria todo o esforço da educação escolar. O termo "moralização" é entendido aqui como a moral destinada a ser incorporada pelos indivíduos, o poder sobre si mesmo exercido a partir do interior (SILVA, 2011). Para o seu ensino, foi necessário que as representações acerca do conceito de "moral" saíssem da abstração e fossem transformadas em práticas, como por exemplo, nas festas cívicas e beneficentes, bem como na disseminação de um discurso legitimado pela idéia de autocontrole, de Deus e de nação (SILVA, 2011) ${ }^{108}$.

Para transformar a moral em educação e a educação moral em moralização, ou seja, para que a moral fosse incorporada pelas pessoas, comandasse os seus atos e fosse transformada em práticas,

\footnotetext{
107 A despeito dos esforços de separação entre o que pertencia à Igreja e ao Estado, foi possível perceber que alguns elementos da moral cristã associaram-se a outros de ordem cívica, ambos com o objetivo de civilizar e formar os futuros cidadãos para as nações.

${ }^{108}$ Apesar das discussões da autora sobre o processo de moralização das escolas públicas tomarem, como pano de fundo, o período de democratização do ensino, especialmente as décadas de 1940 e 1950 , no caso brasileiro, foi possível retomar a conceituação da moral escolar. Nesta pesquisa, vários textos localizados na imprensa de ensino e que trataram da moralização dos professores e dos alunos versaram, principalmente, sobre os seguintes temas: comemorações cívicas, festejos e desfiles patrióticos aliados aos princípios morais e aos valores nacionalistas que deveriam ser ensinados na escola (SILVA, 2011, sublinhados meus).
} 
era necessário que os indivíduos inicialmente aprendessem a controlar e a inibir as suas paixões e os seus desejos, associados àquilo que há de primitivo e selvagem nos seres humanos, para então chegarem à maestria de si, associada à civilidade e à imposição de um padrão de conduta no espaço social, e ao autocontrole (SILVA, 2011, p. 17).

As práticas educativas empreendidas tinham como objetivo concretizar a moral escolar e garantir o controle dos desejos e das paixões, ou seja, de tudo que poderia ser caracterizado como primitivo e selvagem (SILVA, 2011) para o meio escolar. Aos professores, caberia a demonstração de condutas exemplares aos estudantes e o ensino das representações e das práticas associadas ao conceito de moral escolar. Por meio de rituais pré-estabelecidos, as instituições escolares deveriam incutir a moral no comportamento das pessoas, transformando os valores em atitudes. Assim, seria indissociável formar o corpo, o conhecimento e a moral refletida em uma série de costumes e normas relacionados à vida em coletividade, como por exemplo, o civismo, a caridade e o respeito ao outro, que dependeriam da formação da vontade do indivíduo para que se concretizassem. As normas morais seriam incorporadas pelas pessoas através de um movimento que levaria das representações e dos discursos às práticas (idem). Considerando que na sociedade existem convenções que auxiliam na ordenação do comportamento moral dos indivíduos, "nas escolas as crianças seriam preparadas para aceitá-las e para aprender a se comportar diante de tais convenções, condicionando o seu cotidiano através do controle da sua alma" (SILVA, 2011, p. 31-32). As comemorações de caráter cívico, como as homenagens aos vultos nacionais, os estudos dos fatos históricos, as excursões, as festas nacionais, os hinos, as canções patrióticas e as poesias também auxiliariam na formação prática das virtudes morais (SILVA, 2011).

Nesse sentido, as festas beneficentes assumiram um duplo papel: ensinar a moral escolar aos alunos e aos participantes dos eventos e atenuar as condições materiais precárias de ensino de algumas escolas portuguesas. Para a concretização desse projeto, as iniciativas de professores, diretores e inspetores de ensino, bem como de políticos e de alguns comerciantes, em outros momentos, na organização dos eventos festivos, foram fundamentais para "minorar muito desgosto, muita tristeza - porque a carência de auxílio é manifesta - ainda em muitas escolas, devido à tenacidade de muitos colegas, elas se realizam" (A escola primária, 22 de dezembro de 1927, p.04).

A função de prover materialmente as crianças e as famílias mais necessitadas concretizou-se na festa de Golegã, em Portugal, como foi noticiado no periódico $A$ Escola Primária: “(...) realizou-se há dias uma festa encantadora: uma distribuição de 
vestuário, calçado e livros, etc., por 62 crianças pobres das escolas dessa vila, tudo no valor de dois mil escudos, gastos pela Caixa Escolar" (A Escola Primária, janeiro de 1929, p. 100). Além de roupas, calçados e livros, outras localidades ofereceram refeições para os alunos que, depois da cerimônia, em "alegre romaria, todos os presentes se encaminharam para uma improvisada sala de jantar ornamentada pelos alunos. A todas as crianças da escola foi servida uma suculenta refeição e ainda", a algumas delas, foram distribuídos gêneros alimentícios para levarem para suas casas (idem, p. 249). Já em Alcaçovas, nas palavras do professor Oliveira Charrua, “foram distribuídos prêmios de aproveitamento e peças de vestuário a 36 alunos, assim como bolos e rebuçados a todos" (A Escola Primária, fevereiro de 1930, p. 49). Aos rituais estabelecidos para as festas escolares, foram acrescidos outros, característicos deste tipo de acontecimento, como a distribuição de materiais escolares, vestuário e alimentos aos alunos desfavorecidos. A utilização da máquina festiva com função de suprir materialmente a vida escolar nos dá indícios das dificuldades enfrentadas pelos primeiros governos republicanos para consolidar aparato público e estatal de ensino, assim como atestaram os diferentes ritmos associados a esse processo nas diferentes sociedades.

Como instituição criada para auxiliar as crianças matriculadas nas escolas públicas primárias brasileiras e portuguesas, as Caixas Escolares ou Infantis foram implementadas com a ajuda dos pais e mestres com o objetivo de minimizar as dificuldades financeiras de algumas famílias de alunos. Para isso, tais instâncias escolares poderiam promover festas em dias não determinados pelos calendários escolares oficiais com o intuito de exercer a beneficência para os alunos pobres, além de realizar outras ações, como conceder prêmios aos melhores alunos como forma de incitar ao estudo (Revista Infantil, 15 de abril de 1922, p. 191). Os recursos provenientes das comemorações escolares constituiriam os fundos de auxílio aos mais necessitados, que poderiam ser gastos na compra de material escolar, roupas ou uniformes escolares, calçados, benfeitorias para a escola e compras de prêmios a serem distribuídos nas festas.

As doações às instituições escolares e aos alunos foram realizadas não somente em festas com estes propósitos definidos, mas ocorreram em outros momentos dos calendários social e escolar, especialmente nas comemorações natalinas, ou nas cerimônias de encerramento do ano letivo, com a apresentação de trabalhos escolares. $\mathrm{Na}$ época do Natal associava-se ao "espírito de caridade cristã", as dificuldades pelas 
quais passavam os alunos e suas famílias, tornando-se ocasiões bastante propícias aos atos de doações, mesclando-se, desse modo, e mais uma vez, os calendários e a moral cristã aos escolares. No Natal, outras crianças além das regularmente matriculadas, poderiam se beneficiar do "espírito de caridade" que envolvia toda a sociedade:

\begin{abstract}
A nossa festa (...)
É dia de festa nesta casa no próximo dia 24 . Vinte e duas crianças pobres aqui virão receber os seus fatinhos, os seus brinquedos e terão um lunch em que não faltarão as guloseimas. Solenizaremos assim, ao mesmo tempo, o Dia do Nascimento de Cristo e o da nossa Revista. E fa-lô-emos porque boas almas acudiram generosamente ao nosso apelo (...) (Revista Infantil, 15 de dezembro de 1922, p. 240).
\end{abstract}

Em Ameixoeira - Portugal, realizou-se no primeiro domingo do mês de janeiro de 1934, logo após as férias de final de ano daquele país, "uma simpática e instrutiva festa na escola no 67”, que, segundo o autor, era acompanhada "todos os anos, por esta época, temos o prazer de assistir a esta mimosa festa organizada com todo o carinho pela ilustre diretora daquela escola" (A Escola Primária, 20 de janeiro de 1934, p. 249. O motivo principal da reunião das muitas crianças que frequentavam aquela escola era a exposição dos trabalhos realizados durante as aulas, ocasião "para desenvolver a observação e expressão dos alunos" e, para complementar este "ato verdadeiramente instrutivo há a festa de confraternização entre os alunos e os muitos amigos da escola" (idem), sendo sempre aproveitada a oportunidade "para a distribuição aos alunos, dum fatinho completo e igual para todos" (ibidem), oferta "delicada e carinhosa conseguida com o esforço da bondosa professora que dirige aquela escola e com a dedicação inexcedível de seu Exmo. Esposo e do auxílio deveras apreciável dos muitos subscritores do fundo escolar" (A Escola Primária, 20 de janeiro de 1934, p. 249). Após a exposição dos trabalhos, houve os discursos das autoridades presentes e ao final, “depois do Hino da Escola, tivemos o prazer de ouvir algumas canções alegres e próprias para as crianças" (idem).

No mês seguinte, a revista registrou outra notícia que indicava mais detalhes sobre o evento, com informações sobre a quantidade de crianças contempladas (25), acerca das roupas distribuídas (fatos feitos sob medida), dos brinquedos (dois) e alimentos doados (biscoitos finos e chocolates), além de distribuição de publicações educativas. Na ocasião, o diretor da Revista Infantil discursou, explicando o que significava o evento e incitando às crianças contempladas a seguirem o exemplo de Jesus: 


\begin{abstract}
A Nossa Festa
Podemos afirmar, sem qualquer sombra de exagero, que a festa realizada na nossa Redação, para solenizar o $7^{\circ}$ aniversário da 'R.I' e o nascimento de Cristo, foi o melhor que podia ser, e o seu resultado excedeu toda a nossa expectativa.

Foram contempladas 25 crianças pobres, que no dia 24 de dezembro, quase todas com as suas famílias, receberam os donativos. Coube a cada uma, além do fatinho feito por rigorosa medida, dois brinquedos, um pacote de biscoitos finos, chocolates e publicações educativas.

A distribuição começou às $2 \frac{1}{2}$ horas da tarde, com a assistência de vários subscritores e de muitas crianças que vieram acompanhar os seus irmãos necessitados, rodeando todas, com muita alegria, a linda árvore de Natal que apresentava os brinquedos e muitos enfeites apropriados.

Ao iniciar-se a Festa, o Diretor da 'R.I' pronunciou algumas palavras explicando às crianças o que significava o ato, dizendo, no final, que como agradecimento, a 'R.I' e os subscritores apenas desejavam que as crianças contempladas seguissem o conselho de Jesus: 'Amai-vos uns aos outros'.

Todas as crianças e suas famílias, a quem foi servido um pequeno copo de água, manifestaram sempre a maior alegria e despediram-se muito satisfeitas. Durante todo o dia a nossa Redação foi visitada por crianças que admiravam a Árvore, e tomavam parte na alegria deixada pelos pobrezinhos (Revista Infantil, 15 de janeiro de 1923, p. 246).
\end{abstract}

As iniciativas para a organização de eventos em benefício das escolas e das crianças mais necessitadas eram vistas com bons olhos, indicando um interesse social pelo progresso e desenvolvimento das escolas personificadas em seus alunos. Elas foram noticiadas de forma bastante elogiosa nos periódicos educacionais que, na então considerada "época de apagada e vil indiferença por tantas coisas que diretamente respeita ao bem-estar da Escola e do seu (ilegível) tivessem em larga escala os mais entusiastas imitadores" (A Escola Primária, 21 de fevereiro de 1929, p. 165). Todas as ações em prol do desenvolvimento do ensino e apoio aos escolares deveriam ser conhecidas e exaltadas e, nada melhor para isso, do que o uso da visibilidade permitida pelas festas escolares.

Associadas ao bem estar das crianças, e representadas como serviços indicativos do progresso do ensino, as inaugurações e aniversários das cantinas escolares também se constituíram em eventos relevantes a serem noticiados e exaltados em festas específicas para elas. Prática recorrente na sociedade portuguesa, a realização das comemorações de inauguração e de aniversário das Cantinas Escolares representou um momento de reconhecimento da população para a relevância da causa do ensino. Em 20 de junho de 1929, a revista portuguesa A Escola Primária registrou a inauguração de Cantinas Escolares nas Escolas n. 15, e 71 e na Escola Primária da Junta de Arroios, que 
só puderam ser realizadas, segundo o periódico, devido à "diligência dos ilustres diretores destas escolas" e à boa vontade e auxílio das Juntas de Freguesia. Assim como em outros eventos, houve a participação de personalidades políticas indicando a importância do evento e das iniciativas políticas e da população local, representada pelas Juntas de Freguesia, para a melhoria das condições de ensino:

Para o efeito da inauguração houve uma sessão solene a que presidiu o Sr. Governador Civil. O representante da Junta leu uma elucidativa exposição dos trabalhos realizados para o bom êxito do útil empreendimento a que tinham posto ombros e os nossos prezados colegas diretores daquelas escolas, Sra. D. Carolina Vasquez e Ernesto Coelho agradeceram em termos de sinceridade e apreço o auxílio da Junta e a presença do Sr. Governador Civil que, em firmes palavras se regozijou por mais uma cantina (...) (A Escola Primária, 20 de junho de 1929, p. 331).

Além dos momentos descritos, criou-se, na sociedade portuguesa, o "Dia da Boa Vontade", comemorado pela $11^{\text {a }}$ vez em 18 de maio de 1932 pelos escolares, que representou bem o ensejo de criação e consolidação da solidariedade internacional a partir de uma série de acordos realizados nas Conferências de Haia, de 1899 e 1907, e de divulgação de valores cívicos reconhecidos internacionalmente. Naquela ocasião, comemoraram-se iniciativas de apologia à paz e a aproximação "de todas as crianças do Mundo; proporcionando-lhes o meio de se estimarem e se auxiliarem mutuamente", cabendo aos professores ministrarem "lições especiais para enaltecerem os benefícios da amizade internacional e em muitas escolas realizam-se festas alusivas à comemoração tornado-o assim mais significativa" (A escola primária, 5 de maio de 1932, p. 39).

A celebração do "Dia da Boa Vontade" poderia, nas palavras dos educadores da época, ser considerada "uma campanha humanitária em favor da Paz Mundial", na qual "a mocidade britânica, endereçando a sua mensagem a todas as crianças do mundo, lembra-lhes a conveniência duma harmonia cada vez mais solidária entre todos os homens, para se evitarem catástrofes horríveis, como a da Grande Guerra" (idem, 20 de maio de 1933, p. 57). Talvez, os educadores, inspirados pelas iniciativas inglesas da instituição de um dia para comemorar a paz e incitar a solidariedade entre os povos, criaram na sociedade portuguesa o "Dia da Bondade", depois transformado na "Semana da Bondade". Considerada uma iniciativa simpática, pretenderam "os seus promotores 'dar a todo o País uma grande lição de sentimento, louvando a prática do bem, enaltecendo o dever da caridade, aconselhando a virtude", bem como criando " maior respeito pelas coisas, mais carinho pelos animais, melhor compreensão espiritual de tudo o que nos cerca"” (A Escola Primária, 05 de março de 1934, p. 09). 
As ações beneficentes indicativas da moral escolar e organizadas em ocasiões solenes poderiam realizar-se por meio de doações de roupas, materiais escolares, livros, alimentos, refeições, provimento material das escolas, quantias em dinheiro em beneficio das Caixas Escolares e criação das Cantinas Escolares. Mais do que prover materialmente as escolas, as festas beneficentes incitaram sentimentos de solidariedade e de abnegação constituinte de uma moral escolar a ser disseminada. As comemorações realizadas nas escolas pelos professores e alunos constituíam situações agradáveis e descontraídas para angariar os donativos necessários para o desenvolvimento do ensino. Desse modo, um dos aspectos sociais mais importantes das comemorações era o seu caráter solidário, que "fazia com que a Escola, através da festa, assumisse o papel de instituição de caridade social". Nessas ocasiões, os mestres tentavam suprimir as lacunas materiais dos alunos, contribuindo para o aumento da população escolar, que percebia na escola, possibilidades de melhorias materiais e intelectuais, e em um projeto maior para a "formação duma Nação letrada e culta", criando ainda, nos alunos, sentimentos nobres e altruístas (PEREIRA, 2006, p.85).

\subsection{As festas da natureza: festa das aves e das árvores}

"A velha árvore"

Uma vez um lenhador, Homem bom, porém severo D'olhar sombrio e austero, Cortava com seu machado,

Bela árvore frondosa,

Que se elevava garbosa, Não mui longe do povoado.

Passou naquele momento, Por ali, todo alquebrado, Um velho já bem cansado, De viver e trabalhar! Com seus olhos rasos d'água, Demonstrando muita mágoa, Começou ele a falar:

Por que cortais, meu senhor,

Este tronco tão robusto, Que aqui com tamanho custo, Plantei com tanto amor?!

Á sombra amena e querida, Da ramagem verdejante, 
Descansava o viandante,

Pousados nos curvos ramos,

Cantavam os gaturamos,

Da manhã ao despontar.

Perdão pela minha falta, Respondeu o lenhador; Avalio a vossa dor

Pelo mal que pratiquei.

No tugúrio em que me abrigo,

Falta o fogo, falta o trigo,

Aos filhos que sempre amei

(Revista de Ensino, dezembro de 1917 e março de 1918, p. 89).

Representadas pelas árvores e aves, as festas da natureza foram realizadas em diferentes contextos educacionais durante o período estudado, em escolas públicas ou particulares, confessionais ou leigas; todas deveriam celebrar, fosse por iniciativa individual ou coletiva, as datas indicadas ao culto da natureza seguindo um ritual previamente determinado, bastante semelhante ao das demais solenidades. Como indica o poema acima, fazia parte dessas solenidades, despertar nos assistentes (alunos e comunidade) os apreço e zelo à natureza, representada como a riqueza do país, cujo desmatamento só deveria ocorrer em caso de extrema necessidade, como refere o lenhador no último parágrafo: "pela falta de fogo para preparar os alimentos". Entretanto, às funções propostas inicialmente pelo Estado de incutir valores relacionados ao cuidado com a natureza num contexto de crescente urbanização e industrialização, como aconteceu no século XIX (SoUZA, 1998), foram acrescidas outras, com o advento das repúblicas brasileira e portuguesa associadas à concretização de conceitos abstratos como pátria, nação, república e civismo por meio dessas comemorações. A árvore, acionada como mecanismo simbólico nessas solenidades, passou a representar o "lugar de memória", a recordação do passado às gerações vindouras, o símbolo de regeneração, representativa da capacidade de renovação característica da natureza, do mesmo modo que a república se apresentou como regeneradora de uma pátria (CATROGA, 2000).

A escolha da árvore e a posterior associação entre a natureza e a pátria, foram concretizadas nas festividades realizadas por ocasião da Revolução Francesa (1789 1799), a quem coube as primeiras tentativas organizativas do imaginário republicano e de disseminação de valores associados a ele por meio de signos concretos e, dentre estes, a árvore. O movimento revolucionário instituiu, como uma das formas de se evitar o esquecimento dos fatos que o constituíram, a criação das comemorações e, por 
meio delas, da disseminação de símbolos como a bandeira, representante da nação, e das árvores, como imagem da renovação social pretendida; a partir daquele momento, elas foram selecionadas para fazer parte de todas as festividades que homenagearam a república (OzOUf, 1976). Caberia aos eventos festivos associados à árvore, "ligar, no espírito da criança que as semeou ou plantou, e que mais tarde as irá encontrar crescidas e frondosas, o passado com o futuro" (CATROGA, 2000, p. 281), bem como permitir a visualização de um futuro promissor, revigorado e progressista. A árvore, assim como a bandeira, pretendiam a formação do cidadão por meio de percepções sensíveis, ao mesmo tempo em que simbolizavam a república e o seu ideal de liberdade de escolha nos destinos das nações. Sendo assim, o culto da árvore poderia ser entendido como uma prática simbólica, chamada para a socialização política dos cidadãos no modelo político republicano.

Apesar de serem os eventos menos noticiados nos periódicos educacionais dos dois países ${ }^{109}$, as festas da natureza destacaram-se no corpus documental pela sua possibilidade de construção de um novo referencial social e político, não mais associado à monarquia e a igreja católica, mas sim, aos valores laicos e a formação do cidadão republicano. Entretanto, a substituição dos símbolos religiosos pelos laicos nas escolas não aconteceu de forma consonante, mas contraditória e ambivalente, de adesão e repulsa a estes elementos, de acordo com o regime político que se vivia.

No regime monárquico, por exemplo, as instituições de ensino uniram-se aos valores católicos, fazendo propaganda dos mesmos e contando com a presença eclesiástica nas celebrações escolares; já no contexto republicano pretendeu-se uma ruptura e designação da escola como instituição que precisava desempenhar a função simbólica, que antes era da igreja: deixou-se de lado o culto ao sobrenatural para se dedicar ao culto da natureza, especialmente o da árvore como substitutivo dos anteriores (PEREIRA, 2006). Os regimes políticos, monárquico ou republicano, desejaram condicionar as relações e os sentimentos que a escola e suas festas deveriam nutrir pela igreja, alternando-os entre a religiosidade cristã e a cívica. Entretanto, o propósito de supressão dos elementos religiosos das instituições de ensino e de suas festas no projeto republicano não foi realizado sem resistências e algumas permanências, o que permitiu

\footnotetext{
109 Ao todo foram publicadas, durante o período, 11 notícias sobre as festas da natureza nos periódicos brasileiros e 13 nos periódicos portugueses.
} 
que, em alguns momentos, tal proposta fosse contestada em notícias veiculadas sobre as festas e revertida, até a sua retomada, na década de $1930^{110}$ :

Em Oeiras realizou-se em fins de Maio, uma festa escolar e nela um senhor orador, referindo-se à Festa da Árvore, afirmou o antigo espírito com que tal festa dantes se fazia, e que, em seu entender, era, nem mais nem menos, afastar a criança da ideia de Deus e aproximála da natureza.

Aqui confessamos que nunca demos por isso, nas muitas Festas da Árvore a que assistimos. Por mais de uma vez promovemos a realização dessa festa e aqui juramos que nunca nos passou pela cabeça afastar as crianças da ideia de Deus.

Portanto, quem deve andar afastado da verdade dos fatos é o senhor orador de Oeiras (A Escola Primária, junho de1934, p. 05).

Além das influências dos ideais republicanos franceses, as festas das árvores realizadas no Brasil e em Portugal contaram ainda com elementos provenientes da comemoração instituída nos Estados Unidos, denominada Arbor Day. Aproximadamente cem anos após a Revolução Francesa, os EUA encetaram a popularização do plantio de árvore em cerimônias públicas, iniciada com a política de arborização do país, em 1872. Na tradição americana, assim como na francesa e, posteriormente, na brasileira e na portuguesa, a árvore simbolizava a liberdade que o regime republicano permitiria instaurar. A influência norte-americana pode ser percebida com maior ênfase no contexto educacional brasileiro; em Portugal, quase não se encontra referências ao Arbor Day. No contexto paulista, algumas notícias e comentários sobre eventos celebrativos da natureza vieram até mesmo com o título em inglês (Revista de Ensino, agosto de 1902 e dezembro de 1902; janeiro de 1906).

Uma das primeiras notícias sobre as festas das árvores nos documentos brasileiros foi registrada sob o mesmo título da festa norte-americana Arbor Day nas páginas da Revista de Ensino em 1902. A organização dessa comemoração em homenagem às árvores foi levada a efeito pelo então engenheiro-chefe do $2^{\circ}$ distrito agronômico, Exmo. Sr. Dr. João Pedro Cardoso e aconteceu na cidade de Araras, nos primeiros dias do mês de junho. O programa da solenidade contava com alocuções acerca da importância da natureza como símbolo da pátria brasileira, o plantio de alguns gêneros de plantas e, como registrado no final, na distribuição de cartões comemorativos aos alunos e convidados. O evento ocorrido na cidade de Araras foi muito apreciado pelos editores da Revista de Ensino, e, divulgado nas páginas da

\footnotetext{
${ }^{110}$ Em Portugal, no período do Estado Novo (década de 1930), a escola e a igreja voltaram a se unir e se ajudar na organização das festas escolares, que passou a adotar rituais e símbolos religiosos, antes rechaçados.
} 
revista, se tornou modelo para as solenidades que se seguiram. No ano seguinte, 1903, registraram uma festa das árvores parecida, na cidade de Itapira (São Paulo). A comemoração iniciou-se com a apresentação da banda tocando o Hino Nacional, depois as crianças cantaram o hino das árvores; houve ainda o plantio de mudas diversas, os discursos de personalidades ilustres da sociedade local e a devida homenagem ao precursor desta atividade nas escolas do Estado de São Paulo.

O gentilíssimo povo de Itapira acaba de realizar mais uma imponente festa de educação.

Como festa de educação a consideramos, a festa das árvores, essa instituição yankee, já transplantada para alguns países europeus e que em boa hora, foi brilhantemente iniciada no nosso Estado, pelo zeloso inspetor do $2^{\circ}$ distrito agronômico, Dr. João Pedro Cardoso.

No belíssimo parque, (...), achavam-se em alas cerca de 400 crianças, alunas do grupo e das outras escolas depois de terem efetuado uma deslumbrante passeata pelas ruas da cidade, por entre a admiração e as aclamações do povo (Revista de Ensino, junho de 1903, p.121).

Em Portugal, a árvore surgiu como metáfora no discurso político oitocentista, e seria necessário esperar pelos movimentos ideológicos republicanos para a sua inclusão na pedagogia cívica. Foi somente depois da implantação da república em Portugal, que esta festividade recebeu um notório incremento, constituindo-se na primeira festa cívica a ser realizada após o advento do novo regime. A escolha da data para sua comemoração foi extremamente significativa; geralmente, as festividades eram realizadas durante o mês de março, passagem do inverno para a primavera naquele país. Um elemento importante de qualquer festa da árvore em Portugal era o cortejo cívico, composto pelas autoridades locais - simbolizando o apoio oficial à iniciativa, pelas diversas associações da localidade - e pela presença de bandas, que percorriam as ruas das cidades até o local de plantação das árvores, preferencialmente no campo. Por meio desse ritual festivo ficava explícita a doutrinação política e ideológica que se pretendia, ou seja, influenciar e impregnar os cidadãos do espírito da república, utilizando-se, principalmente, do entusiasmo coletivo que ela desencadeava para promover ideais como a unanimidade, a fraternidade e a igualdade (CATROGA, 2000). O apelo aos sentimentos e emoções, incentivados pelos pedagogos adeptos da pedagogia renovada para a formação integral do indivíduo era aqui retomado para a garantia da eficiência na formação do cidadão republicano.

Uma das primeiras celebrações associadas à natureza foi realizada em Portel, a dois de abril de 1911. A festa teve início com um "vistoso cortejo", no qual estavam presentes autoridades e corporações, a escola do sexo masculino daquela localidade, a 
banda do Grêmio Portelense, convidados ilustres e o povo. Uma carreta, conduzida por 10 crianças, transportava a árvore; à frente do desfile, um aluno empunhava a bandeira nacional; no parque, a professora e os alunos procederam a plantação da árvore ao som de A Portuguesa; depois, realizou-se no Paço do Conselho uma sessão solene onde foi explicado o significado da festa (CATROGA, 2000). A cerimônia servia de pretexto para a consagração de símbolos do novo regime - a bandeira, o hino e a árvore - e para a reafirmação dos valores escolares. A prática da plantação de árvores em eventos com a participação de escolares não foi inaugurada por esta festa, pois já tinha sido realizada uma outra, em dezembro de 1907, sob iniciativa da "Liga Normal de Instrução", que orientava professores e crianças das escolas de Lisboa a plantarem, na Rua Alexandre Herculano e ao som de da banda de música da Infantaria, por volta de 16 e 38 árvores ${ }^{111}$ (idem):

No ano seguinte, 1500 crianças aborizaram a Avenida Casal Ribeiro, continuando uma prática em que se pedia aos professores que, a par de preleções sobre as árvores, as aves e a agricultura, mandassem os alunos plantar árvores 'ao som de música coral e instrumental e de quaisquer outros elementos que alegrem e interessem as crianças e o povo (CATROGA, 2000, p. 281).

Em 1923, foi publicada uma das regularizações normativas da festa da árvore em Portugal nas páginas da Revista Escolar de 1923, sob o título Portaria de 17-31923. De acordo com esse documento, os profissionais da educação deveriam "realizar a festa da árvore nas escolas de ensino normal, primário superior e primário geral”, "considerando que o culto da árvore - símbolo do amor à natureza - tem um alto valor educativo", pois "concorre para uma mais perfeita e íntima integração do homem com a terra que constitui a base geográfica da sua Pátria" (Revista Escolar - Portugal, março de 1923, p. 96). Considerando tais argumentos, "muito convém estimular, desenvolver e dar caráter cívico e sentimental a esse culto" (idem), em todos os níveis de ensino:

Manda o Governo da República Portuguesa, pelo Ministério da Instrução Pública, que em todas as escolas de ensino primário normal, de ensino primário superior e ensino primário geral, dependentes deste Ministério, se escolha um dia do próximo mês de Abril destinado a celebrar a festa da árvore, que deverá ser realizada com a cooperação de todos os professores e alunos e acompanhada de preleções de feição patriótica e educativa (Revista Escolar - Portugal, março de 1923, p. 96).

\footnotetext{
${ }^{111}$ Cerimônias análogas ocorreram em Pernes e em Setúbal (CATROGA, 2000).
} 
Imbuídos dos valores patrióticos associados à natureza do país, o Grupo de Propaganda Educativa "Fraternidade", apresentou em $1933^{112}$, para a sociedade portuguesa, um relatório com a proposta de criação de Sociedades Infantis protetoras de aves e plantas. Neste documento apresentado em forma de Estatuto, caberia à sociedade e, em especial as crianças, "a proteção aqueles seres como um admirável meio educativo e como meio de defender a riqueza nacional" (A Escola Primária, outubro/ novembro de 1933, p. 158). De acordo com o artigo $8^{\circ}$ do Estatuto mencionado, todos os anos, na primavera, se efetuariam as festas da natureza, aves e árvores, com um ritual específico e, de preferência, no campo. A fim de garantir o interesse e entusiasmo das crianças, os pais e professores procurariam tornar alegres e, tanto quanto possível, proveitosas estas festas: "haveria, por exemplo recitações apropriadas, colocação de ninhos artificiais para as aves, plantação de árvores, jogos apropriados, etc" (idem, ibidem). No dia indicado para a celebração ainda seriam distribuídos folhetos, postais, cartazes e selos, como propaganda entre os adultos no sentido de os levarem a estimar e proteger as aves e as plantas (A Escola Primária, outubro/ novembro de 1933, p. 158).

O professorado, como os pais, teriam, é certo, um pouco mais de trabalho com a iniciativa. Mas, em compensação, recolheriam benefícios, pois bem sabido é que, à dulcificação dos bons sentimentos morais das crianças, correspondem sempre, como sequência lógica, um melhor aproveitamento intelectual e um aumento da disciplina e respeito mútuo (...) (idem, ibidem).

O culto da árvore foi idealizado no contexto escolar como uma grande lição de moral e um auxílio valioso na formação do caráter e na orientação da inteligência das crianças; mediado por sua intenção pedagógica se ritualizava a lição de historicidade e solidariedade que estava implícita nos manuais de educação cívica e moral (CATROGA, 2000). No discurso do professor José Victorino da Silva, em 1915, a festa da árvore em Miragaia, Portugal, foi a realização da mais "bela das religiões", a do culto da natureza, considerada uma "festa do amor, genuinamente popular" poderia "mais de perto tocar a alma nacional" permitindo que nela desabrochasse "as flores mimosas da inteligência infantil". No que diz respeito ao aprendizado, logo as crianças perceberiam, por meio das festas, a noção prática de utilidade que se pode tirar da terra. Para Silva (1915), o valor educativo dessas celebrações era prático e seguro, já que radicaria no "espírito das

\footnotetext{
${ }^{112}$ A iniciativa de criação de uma instituição de proteção da natureza na década de 1930 pode ser considerada um indicativo da consolidação de alguns ideais da pedagogia renovada no contexto educacional português.
} 
crianças uma agradável impressão viva e duradoura sobre o amor consagrado às árvores" (O Magistério, março de 1915, p. 03).

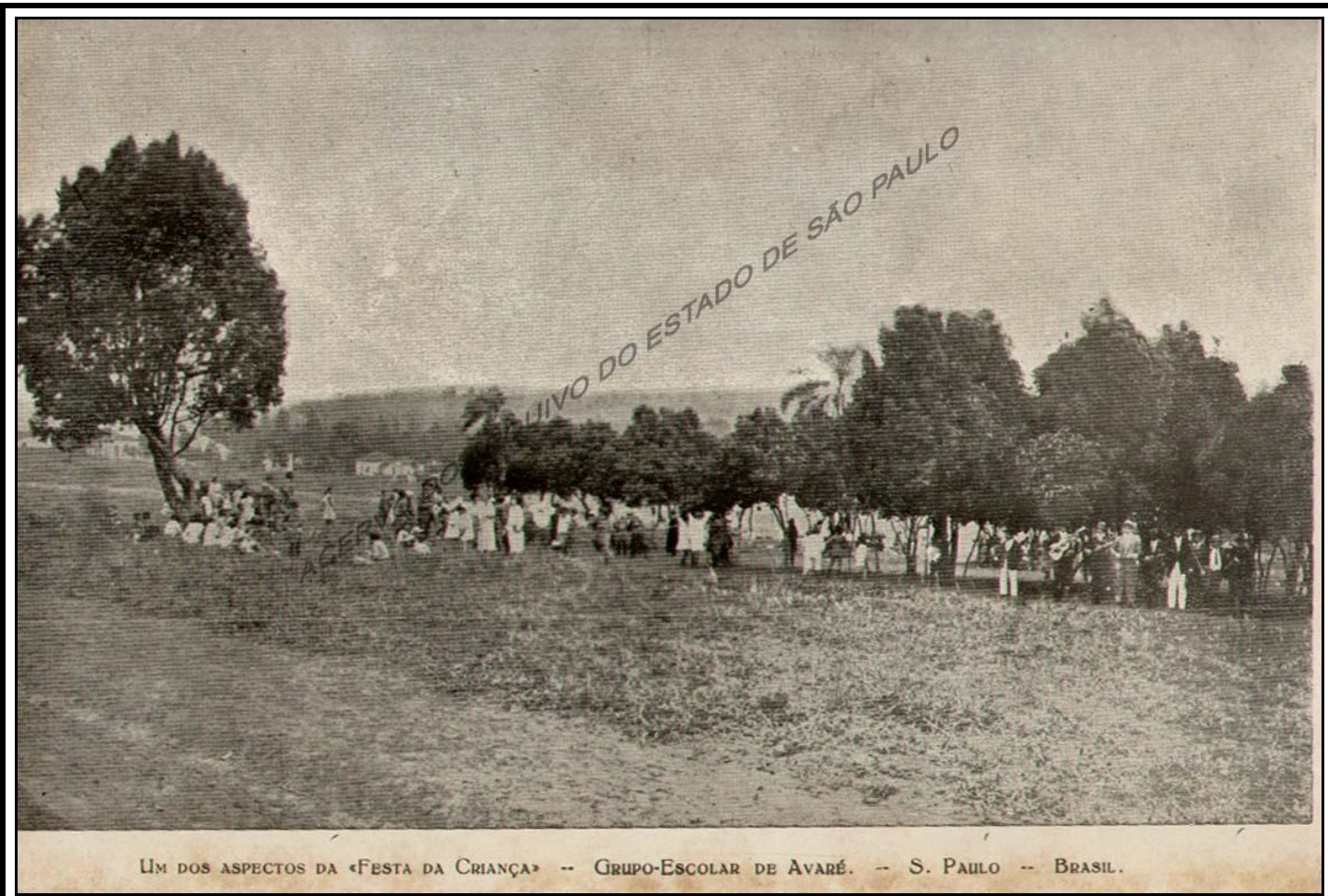

Revista Escolar, agosto de 1927, p. 33.

No Brasil, no ano de 1916, em discurso proferido por Olavo Bilac e transcrito nas páginas da Revista de Ensino de São Paulo intitulado "O culto da pátria”, criticavase os poucos esforços vigentes para a constituição da nacionalidade brasileira; para Bilac, ainda vivia-se em uma pátria que não conhecia o patriotismo, e, por fim, terminava seu discurso reafirmando a associação que deveria existir entre a Pátria e a árvore: assim como a árvore, a pátria "quer viver, reverdecer, reflorescer, rebentar em nova e fecunda frutificação, mas para isso precisa que os estudantes dêem-lhe suas almas, seus braços, sua generosidade, seus sacrifícios" (idem, p. 47). A recorrência da utilização das metáforas associadas ao conceito pátria foi indicativa dos desejos desse autor para o futuro da nação que, para "florescer e rebentar em fecunda frutificação", deveria contar com indivíduos "fortes" e devidamente imbuídos dos sentimentos patrióticos.

Além dos elementos assinalados por Olavo Bilac (1916), dentre os pontos negativos da solenidade estariam ainda a irregularidade das festas escolares, a falta de policiamento para tais eventos, a eventual desorganização do cortejo escolar, a falta de transporte para levar os alunos e mestres para o local da comemoração, a avareza dos 
lunchs e, considerado mais grave, a não participação dos alunos das escolas isoladas, como se os alunos destas escolas não tivessem os mesmos interesses que as de outras escolas mais centrais:

Uma exceção odiosa estabeleceu-se nessas festas infantis afastando-se delas os alunos das escolas isoladas, como si essas pobres crianças não tivessem os mesmos sentimentos que aquelas que freqüentam os grupos escolares (...) Também achamos irregular militarizarem-se crianças e fazê-las conduzir pesadas carabinas e marchar ao toque estridulo de cornetas e tambores, a fim de lisonjear com imerecidas continências aos magnatas políticos, que nada fazem pela instrução popular e só procuram abater o professorado (idem, ibidem).

Como forma de corrigir a imagem pouco proeminente das escolas isoladas no sistema público paulista de ensino, o governo do Estado de São Paulo organizou, no "aprazível logradouro da Antarctica, às escolas isoladas", que por seu "bizarro brilhantismo" constituiu-se o "fecho de ouro do ano letivo de 1907", que perduraria "indelével na lembrança de todos, como uma página Adamantina dos fastos escolares", indicando o trabalho constante e fecundo "de verdadeiro granjeio e operosidade para que a árvore abençoada da instrução pública bracejasse mais algumas protetoras e viventes frondes" (Revista de Ensino, março de 1912, p.49). Foi esta a maneira utilizada pelo governo para inculcar no espírito dos professores das escolas isoladas a certeza de que, isoladas quanto ao tipo de sua organização, "aquelas escolas devem formar pelo critério e esforço de quem as rege um aparelho harmônico e militante nas lides do ensino" (Anuário do Ensino do Estado de São Paulo, 1907-1908, p. 63). A gardenparty, na opinião do inspetor de ensino João Lourenço Rodrigues (1907-1908), foi o auspicioso prenúncio de uma era nova para as escolas isoladas.

A despeito de ser uma tentativa simples, efetuou-se a festa com toda a ordem e brilho, afluindo ao local a maioria dos alunos e professores das escolas isoladas, transportados ao Parque da Antarctica por um comboio especial da Railway Company. O programa estava organizado da seguinte maneira: iniciou os festejos um discurso alusivo ao ato pronunciado pelo Sr. Inspetor Escolar Ramon Roca, logo depois, foram distribuídas medalhas aos alunos que melhores notas obtiveram durante o ano letivo; em seguida, discursou a professora D. Paulina Nacaratto, que salientou os serviços prestados pelo atual governo à instrução pública; falou depois o Sr. Dr. Secretário do Interior que, no decorrer de sua alocução, lembrou o empenho perseverante dos governos de São Paulo para aperfeiçoarem e desenvolverem as escolas públicas, cujo nível ainda estava bem longe de atender às necessidades de divulgação do ensino: 
Ao terminar, S. Exa. concitou os professores a que perdurassem em seus indefesos e patrióticos esforços, mantendo, assim, com lealdade e brilhantismo, as tradições do magistério paulista.

Concluída a primeira parte, debandaram as escolas pelos sítios mais pitorescos do parque, entregando-se as crianças aos folguedos com as ruidosas demonstrações de sua alegria comunicativa.

Durante o festival foram distribuídos bom bons aos alunos.

Planejada e levada a efeito como um simples ensaio, a garden-party excedeu à expectativa de seus organizadores, sendo também certo que ao espírito dos mestres não passou despercebido o seu alcance moral - o de trazer-lhes aplausos pelo trabalho de todo um ano e o de proporcionar aos seus alunos os estímulos e o prazer de uma festa coletiva, de aproximação e camaradagem (Anuário do Ensino do Estado de São Paulo, 1907-1908, p.63-66).

Apesar dos esforços e da realização de muitas festas das árvores em Portugal, um autor desconhecido deixou registrado como forma de crítica nas páginas do periódico A Escola Primária de fevereiro de 1928, os poucos "frutos" provenientes de tais eventos. De acordo com o autor, "a beira de muitas estradas, encontram-se amiúde árvores condenadas a uma morte próxima, porque mãos malfazejas lhes arrancaram um anel de casca no tronco"; para ele, "tais selvagerias" permanecem, pois tem ficado sempre impunes, “o que é um incentivo à prática de novos e idênticos crimes!”. Por fim, conclamava as escolas para reverterem tal situação: “... ó escolas semeai!” (A Escola Primária, fevereiro de 1928, p. 04). Na década seguinte, a diminuição das solenidades das árvores foi reclamada em algumas localidades portuguesas, nas palavras do Sr. Dr. João de Barros (1934): "ao longo de tantas estradas o povo rude dos campos destrói desapiedadamente o arvoredo, descascando parte do tronco a tantas árvores, que só carinho e respeito lhe deviam merecer" (A Escola Primária, 05 de maio de 1934, p. 357). Uma das formas de se evitar esse comportamento seria também por meio da sensibilização promovida pelas festas das árvores.

Por meio dos programas das festas da árvore e dos discursos proferidos nestas, almejou-se incutir nas crianças o amor à natureza, representativa dos conceitos de pátria e república. Ensinar o respeito à natureza, segundo os educadores da época, tinha o mesmo significado que disseminar o patriotismo entre a população. Além disso, as festas da natureza aludiam ao renascimento de uma Nação mais poderosa e mais livre, na qual a escola, em qualquer localidade, ocuparia um lugar de destaque (PEREIRA, 2006, p.48). O potencial educativo dessas festas revelou-se ainda no ensinamento da importância da preservação da vegetação para o progresso, ou para o empobrecimento 
de um país, no caso de desmatamento (Revista de Ensino, dezembro de 1917 e março de 1918, p. 40).

Aos mestres caberia, além da sua missão científica de promoção do ensino laico por meio de métodos de ensino apropriados, a tarefa de ser o 'sacerdote' da religiosidade cívica que a república pretendia socializar; ser o modelo de um verdadeiro republicano e de um patriota (CATROGA, 2000) e marcar, nos eventos celebrativos, a fusão da ideia de pátria com a de república, construindo, assim, novos cidadãos e, a partir deles, a própria democracia. A escola primária passou a celebrar a liturgia política da república, divulgando seus feitos e corporificando símbolos, valores e a pedagogia moral e cívica que lhe era característica. A festa da árvore, como prática simbólica e educativa tornou-se, desse modo, uma das expressões do imaginário sociopolítico da república brasileira e portuguesa (SOUZA, 1998).

O gentilíssimo povo de Itapira acaba de realizar mais uma imponente festa de educação.

Como festa de educação a consideramos, a festa das árvores, essa instituição yankee, já transplantada para alguns países europeus e que em boa hora, foi brilhantemente iniciada no nosso Estado, pelo zeloso inspetor do $2^{\circ}$ distrito agronômico, Dr. João Pedro Cardoso (Revista de Ensino, outubro de 1903, p.121).

Além dos programas e descrições sobre as festas das árvores realizadas nas escolas de diferentes graus, registraram-se nas páginas dos periódicos de ensino, a transcrição de poemas, poesias, hinos, peças de teatro e estórias sobre a natureza e os cuidados que os cidadãos deveriam ter com essa. Foi comum, nesse período, a publicação de livros e edições especiais sobre temáticas específicas das festas escolares; como exemplo, pode-se citar a edição da Revista de Ensino de $1911^{113}$, dedicada em grande parte "à publicação de trabalhos literários - inéditos uns, já conhecidos outros que constituem uma coletânea para a Festa das Árvores, a efetuar-se em setembro, à imitação do que já fez a Diretoria do Ensino para a Festa das Aves comemorada em

\footnotetext{
${ }^{113}$ Nesse exemplar, foi apresentada uma Coletânea para a Festa das Árvores, composta dos seguintes trabalhos: Festa das Árvores por Arnaldo Barreto; Hino das Árvores, música de J. Carlos Dias; Velhas Árvores por Olavo Bilac; Copa Verde por Alberto de Oliveira; Árvore Seca, Alberto de Oliveira; Idílio por Guerra Junqueiro; A locomotiva por A. Gaspar Silva; No Jardim por Casimiro de Abreu; O poema da laranjeira de Arnaldo Barreto; Visita à floresta de Guerra Junqueiro; A lágrima de Guerra Junqueiro; $A$ Primavera de Casimiro de Abreu; O orvalho e a rosa; Magia Selvagem de Alberto de Oliveira; A Árvore de Alberto de Oliveira; Árvore amiga por Antonio Feijó; Ao rebentar das seivas e Canções das rosas por Conde de Monsaraz; Hino à Árvore por Basílio de Magalhães; Os três reinos de Carlos Ferreira; Préstito Fúnebre por Guerra Junqueiro; A Figueira por Filemon Marcondes; Pelas árvores de B. Octavio; Árvore da Rua de Amadeu Amaral; Que plantamos quando uma árvore plantamos? por René Barreto; Seja Benvinda de Clemente Quaglio; Excerto - Prosas Bárbaras de Eça de Queiroz e A Árvore de Coelho Neto.
} 
Abril" (Revista de Ensino, junho de 1911, p.03). O ritual das festas da natureza também se destacou dos demais pela inserção nos programas, de momentos específicos para a prática do plantio de mudas de árvores de diferentes espécies pelos alunos e professores, garantindo, o que desejaram os promotores da renovação de ensino, o "cunho prático" dessas solenidades (Revista Escolar, dezembro de 1925, p.106).

Os professores primários deveriam preparar a festa, de acordo com os programas enviados em circulares oficiais, e selecionar os discursos a serem proferidos por si ou pelos considerados melhores alunos. O preparo e realização da festa deveriam desenvolver nas crianças e na população que delas participavam, sentimentos simpáticos de admiração pela natureza, "predispondo-a ao trato carinhoso a que tem jus as árvores e os pássaros" (Anuários de Ensino do Estado de São Paulo, 1910-1911). Na opinião de José Monteiro Boanova, em relatório publicado nos Anuários em 1910-1911, e enviado ao Secretário dos Negócios do Interior, estas festas eram de suma importância para o desenvolvimento do sentimento nacionalista e deveriam ser realizadas todos os anos no mês de setembro, início da primavera no Brasil.

$\mathrm{O}$ alto alcance, as múltiplas vantagens que oferecem as festas escolares consagradas às árvores e aos pássaros, justificam plenamente a designação de dias especiais a eles consagrados.

As comemorações das datas mais notáveis da nossa história despertam, sem dúvida, o sentimento da nacionalidade, a par do tributo de grata veneração aos nossos antepassados (Anuários de Ensino do Estado de São Paulo, 1910-1911, p. 53-54).

As festas da árvore, no Brasil e em Portugal, eram realizadas no início da Primavera nos dois países, respectivamente, nos meses de setembro e de março. No Brasil, dentre as discussões sobre a melhor data para os eventos, esteve a sugestão feita pelo educador José Monteiro Boanova (1926), de comemorar as festas das árvores e das aves conjuntamente nos meses de setembro de cada ano, como forma de dar mais força ao evento. A sugestão não foi considerada e permaneceu a orientação oficial, prescrita pela Diretoria Geral da Instrução Pública de São Paulo, de se festejar as árvores no mês de setembro e as aves no mês de abril.

Das notícias veiculadas, depreende-se que o progresso de um país ou de um Estado estaria intimamente associado ao cuidado que este teria com a sua natureza, e as festas escolares ou infantis constituir-se-iam uma excelente oportunidade para a afirmação desse ideal educativo, pois, celebrada desde há muito "com toda a pompa, devido à religiosidade dos nossos antepassados, foi ela indispensável, nas escolas dos países cultos e civilizados, como a França e a Alemanha, a Suíça e a Bélgica, a Holanda 
e os Estados Unidos" (Revista de Ensino, junho de 1915, p. 40) e poderia, segundo o educador Francisco Alves Mourão (1915), sugestionar "o espírito do educando para a conquista livre dos ideais e do progresso". Dessa forma, a localidade que se desejasse progressista deveria adotar, dentre outras medidas, a prática das celebrações das aves e das árvores, pois nelas estaria a riqueza dos homens.

Além das árvores, as aves também foram eleitas como representantes da natureza brasileira e portuguesa, devendo, por isso, serem cuidadas e respeitadas. As festas em homenagem às aves seguiram de forma similar os programas executados por ocasião das festas das árvores: recitativos, hinos patrióticos e cantos referentes ao ato constituíam elementos fundamentais dos festejos em qualquer instituição de ensino, mas, diferente das árvores, não se relacionaram de forma tão incisiva ao simbolismo republicano.

\begin{abstract}
A "Festa das Aves" é realizada em abril, em todos os gruposescolares do nosso progressista e querido Estado de São Paulo.

Este ano, no nosso grupo escolar vai, ser muito bonita, com muito recitativos, hinos patrióticos e cantos referentes ao ato, entre flores e vivas, com entusiasmo e, sobretudo, no maior da maior e mais franca alegria da criançada. E é preciso que assim seja, para que aprendamos a amar as aves, estes seres tão úteis quão inocentes, aos quais devemos proteger por todos os meios ao nosso alcance, e não proceder como os ignorantes, que destroem esse tesouro precioso com que nos dotou a natureza, sempre pródiga e benfazeja (Revista Escolar, março de 1926, p.79-80).
\end{abstract}

Em 11 de outubro de 1914, o professor português L. Said expôs no periódico $O$ Magistério, as razões pelas quais Portugal deveria instituir a Festa dos Passarinhos, considerados seres encantadores "que tão necessários são às nossas culturas, à nossa saúde, e que nos deleitam com seus maviosos gorjeios"; ou ainda nas palavras de João T. da Silva Braga, educador brasileiro, seriam "a alegria do espaço, a poesia da natureza, e os seus melodiosos, suaves e dulçurosos cantos a música do Universo!" (Revista de Ensino, junho de 1916, p. 38). Infelizmente, na opinião do professor Said, a população "na sua crassa ignorância", não pensa assim, "não só consentia mas até instigava os seus filhos a que "destruam os seus ninhos, fazendo desta uma guerra cruel” (idem). Neste caso, não existiria "propaganda possível da parte dos professores (daqueles que tomam a sua missão a sério) nem doutras pessoas que tem coração, que as convençam do contrário" (ibidem), sendo necessárias ações mais apelativas, como as festas dedicadas aos mesmos. Por fim, reforça sua argumentação citando Victor Hugo, ao dizer que a "proteção aos animais faz parte da moral e da cultura dos povos" ( $O$ 
Magistério, outubro de 1914, p. 01), ou, em outras palavras, o cuidado com a natureza poderia constituir-se seguro indicativo do nível de desenvolvimento e progresso de um país.

Ao lado das festas dedicadas às árvores e as aves, também eram noticiados os "Garden Party", festividades que aconteciam em lugares abertos e próximos à natureza, geralmente em parques, e que almejaram, assim com as outras duas festas mencionadas antes, incitar o amor à natureza; estas se diferenciaram da festa da árvore pela não realização do plantio de mudas e pelo programa predominantemente composto de jogos e atividades de ginástica realizadas pelos alunos, além do oferecimento de lanches pelas professoras e pais de alunos, como constou em notícia da Revista de Ensino:

(...) era pequeno o recinto do antigo Velódromo para conter as numerosas famílias e muitíssimos cavalheiros que foram, ontem, assistir a primeira festa infantil do Instituto Paulista de Jogos Escolares $^{114}$ (Revista de Ensino, dezembro de 1902, p. 1015).

Nesse evento, os assistentes puderam apreciar a performance dos times de diferentes escolas, com destaque para os times de foot-ball. Dentre as escolas paulistas destacaram-se: o Grupo Escolar do Braz, a Escola Modelo Anexa, a Escola Modelo do Carmo, o Grupo Escolar da Alameda do Triumpho, a Escola Modelo "Caetano de Campos", o Grupo Escolar do Sul da Sé, a Escola Modelo Maria José, a Escola Maria da Luz e o Sport Club Paulista. Além disso, foram publicados literalmente os nomes dos alunos por escolas que mais se destacaram nos jogos realizados (Revista de Ensino, dezembro de 1902).

É possível identificar, nas festas realizadas na e pela natureza, os princípios renovados associados ao interesse e atividade da criança, bem como o da proximidade da natureza para a formação integral do aluno. Essas comemorações, segundo João Lourenço Rodrigues (1907-1908), corresponderiam ao espírito amável da escola moderna, na qual a criança, guiada com a bondade do mestre, deveria sentir-se livre para achar prazer e atrativos sempre novos em seu trabalho cotidiano (Anuários de Ensino do Estado de São Paulo, 1907-1908).

Nada mais belo do que uma festa de crianças das escolas, reunidas em um jardim ou em um parque, sob as vistas dos professores, ora obedecendo à disciplina a que se habituaram nas classes, ora em plena liberdade entregando-se aos folguedos próprios da infância e confraternizando com os coleguinhas de outras escolas (Revista de Ensino, janeiro de 1906, p.781).

\footnotetext{
${ }^{114}$ Associação formada por professores públicos paulistas.
} 
Aos alunos nestas solenidades caberia, ao menos, uma participação ativa - o plantio das árvores nas escolas ou em outras localidades previamente determinadas; além disso, alguns estudantes foram chamados a proclamarem discursos, elaborados por eles ou por outros, sobre a temática da celebração. Foi assim na Festa da Árvore realizada em Portel, Portugal, já descrita nesse capítulo, na qual tomaram parte muitas crianças de várias escolas, e na qual proferiu o discurso o menino Leonardo de Moraes, 12 anos, presidente da comissão da Festa da Árvore daquela localidade. O aluno iniciou seu texto agradecendo a oportunidade, pois era a segunda vez que contribuía com seu "trabalho modesto" para a realização da festa educativa, e o auxílio dispensado pela Câmara Municipal que ofertou as árvores, além da presença da digníssima Banda do Grêmio Portelense que "prontamente acedeu a abrilhantar esta festa" (Revista Infantil, maio de 1912, p. 48). Indicou ainda que uma festa infantil não teria pretensões de uma "comemoração solene", mas seus objetivos principais seriam o de "de difundir a instrução, desenvolver-nos o espírito e formar-nos o caráter" (idem). Segundo o estudante, "aqui não há ostentação, que não é própria das nossas idades, há sinceridade, há desejo de instrução e educação" (Revista Infantil, maio de 1912, p. 48). Ele conclui incitando auxílio à educação:

\begin{abstract}
Mais uma vez apresento a V. Ex.as os meus agradecimentos e os meus sinceros votos para que V. Ex.as continuem a cooperar em todas as iniciativas a favor da instrução contribuindo para o engrandecimento da nossa terra natal. E nós os homens do futuro corresponderemos a esses nobres esforços com a promessa de mais tarde nos tornarmos prestantes cidadãos (Revista Infantil, maio de 1912, p. 48).
\end{abstract}

Ainda naquela festa, mas publicado em número posterior da revista, registrouse o discurso do aluno José Pombinho, de 13 anos, vice-presidente da Comissão Promotora da solenidade. Diferente do texto do aluno presidente é possível perceber, pela linguagem e metáforas utilizadas, que, Pombinho (1912), dirigiu-se de forma mais direta às crianças presentes no evento. Para ele, a árvore pequenina e tenra plantada seria a "perfeita imagem de nós mesmos"; porém mais tarde, "essas árvores agora pequenas hão de produzir frutos, dar sombra com a sua ramagem, purificar o ar, dar vida e beleza ao lugar onde estiverem" e, ainda, "depois de mortas, hão de os seus troncos já secos dar a madeira tão útil às indústrias, dar o combustível para o nosso lar" (Revista Infantil, junho de 1912, p. 52). Assim as crianças, como as árvores, cresceriam, tornando-se fortes e "pelo nosso trabalho tornaremos útil a nossa passagem por este mundo"; e, "depois da morte, poderá ainda a nossa recordação ser salutar, se, pela 
prática de nobres ações, a nossa vida for digna de ser apontada como exemplo às crianças de então!” (idem):

Árvores belas e úteis, cuja vida é para nós conforto e exemplo! Possamos nós mais tarde, quando - crescidos uns e outros, vós tiverdes afrontado as tempestades da natureza e nós as do infortúnio sentir na alma a satisfação do dever cumprido, e a certeza de ter aproveitado os grandes e úteis ensinamentos que a natureza constantemente nos oferece (Revista Infantil, junho de 1912, p. 52).

A publicação dos discursos dos alunos em números seguidos do periódico Revista Infantil indica a centralidade da criança não só nos eventos solenes, mas no espaço aberto pela publicação para a transcrição de suas ideias. Seja em um texto mais formal, para agradecer o público e os colaboradores, seja em uma mensagem mais singela dedicada às crianças, os alunos se fizeram mais que presentes, verdadeiros copartícipes e responsáveis pela realização do evento. A atividade e o interesse dos alunos, princípios de uma educação que se queria renovada, estariam presentes não só na presença dos mesmos aos eventos, mas, também, na proximidade com a natureza propiciada pela atividade, que segundo preceitos da escola nova, constituir-se-iam num verdadeiro laboratório de pedagogia prática, garantindo, ao mesmo tempo um ambiente saudável para o desenvolvimento completo dos alunos. Associados aos princípios da Escola Nova, as festas da natureza ganharam novos sentidos e novos argumentos que justificaram a sua permanência até o período final considerado neste estudo.

Em suma, ao buscar enfatizar aspectos da natureza brasileira e portuguesa, como as árvores e as aves, as festas destinadas a esse fim visaram ensinar às crianças o verdadeiro amor à pátria, contribuindo para o desenvolvimento do sentimento nacionalista e do patriotismo. O conceito abstrato de pátria tornava-se concreto na realização e desenvolvimento da festa e na participação das crianças e sociedade nestas. O patriotismo apresentava-se como a ideologia capaz de gerar o consenso necessário à consolidação da república, desempenhando a mesma função integradora que a religião católica no tempo da monarquia em Portugal e do império no Brasil. A árvore era um símbolo da religiosidade cívica fomentada pelo republicanismo e a força de regeneração que o novo regime pretendia instaurar. 


\section{7 - Celebrar a escola, legitimar o ensino: as festas de inauguração, aniversário e encerramento do ano letivo}

Em um contexto histórico no qual a constituição dos sistemas públicos de ensino tornaram-se políticas estatais de relevo, tão importante quanto realizar ações no sentido de organizar sistemicamente a educação, foi divulgar os feitos governamentais que eram realizados. Neste sentido, a utilização de comemorações para celebrar as escolas ocupou posição de destaque na sociedade e nas páginas dos periódicos de ensino investigados. Com o intuito de dar visibilidade social e política desejada para essas instituições, as festas de inauguração, aniversário e encerramento do ano letivo foram as mais noticiadas no período de estudo. Tudo que se relacionasse com a estrutura física das instituições de ensino e a sua existência nas mais remotas localidades deveria ser festejado: desde a entrega de materiais e mobiliário adequados às escolas, inauguração de espaços, como cantinas e bibliotecas, passando pelas exposições e premiações dos trabalhos escolares, até as ações beneficentes encetadas pelos docentes e discentes no âmbito de suas comunidades para o benefício da escola e da infância desfavorecida deveriam receber grande destaque nos meios sociais.

No âmbito das medidas regulamentares educacionais, as comemorações das escolas assumiram papel tão importante quanto o ato de construir prédios apropriados ao ensino, realizar reformas, elaborar leis e decretos e formar profissionais para a área educacional. Como ações recomendadas oficialmente, as festas serviram para reforçar junto aos alunos, aos professores e à sociedade como um todo, a importância que a educação deveria assumir nos contextos políticos e sociais dos dois países, especialmente após a proclamação dos regimes republicanos.

Ao considerar os acontecimentos mundiais do período, percebeu-se a organização dos aparatos estatais de ensino relacionados aos projetos educacionais engendrados nas políticas de consolidação dos Estados-Nação no decorrer de todo o século XIX. As instituições escolares foram retomadas nesses planos, sob uma nova configuração, como forma de garantir para cada estado nacional o progresso e o desenvolvimento almejados, assim como para garantir certa homogeneidade na formação cultural dos cidadãos. Ao lado da sua tarefa pedagógica, do ensino de conteúdos relevantes para a formação do cidadão, constituíram também suas atribuições forjar uma nova sociedade, moralizada e civilizada, que estivesse de acordo com os projetos da nação (CARVALHO, 1989). Como forma de concretizar esses fins, as festas 
escolares assumiram um papel de destaque, contribuindo por meio do seu ritual, dos discursos e da mobilização social que fomentaram, para a legitimação das escolas como “templos do saber e de luz” (CARVALHO, 1989; SOUZA, 1998).

Organizadas em festas de inauguração de escolas, aniversários, formatura e encerramento do ano letivo e noticiadas durante todo o período considerado para o estudo no caso brasileiro (especialmente nas primeiras décadas após a instituição da República, em 1889) e de forma mais contida em Portugal, foram exemplos dos festejos engendrados para a celebração da escola e do seu ciclo de vida. O início aconteceria com festa de inauguração e o fim com a festa de formatura/encerramento do ano letivo. As comemorações relacionadas à criação das instituições de ensino, expressas na opinião do professor Francisco Furtado Mendes Vianna (1903) visaram assinalar "mais um marco implantado para a senda de seu progresso, mais uma conquista para o seu engrandecimento" (Revista de Ensino, junho de 1903, p. 138).

Nenhuma realização, fossem reformas políticas ou criações de escolas, deveria ser feita no âmbito educacional sem o conhecimento da maior parte da população. A visibilidade permitida pelos festejos públicos foi uma marca distintiva desse tipo de ação e constante em todas as realizações reformistas dos republicanos paulistas. As festas que celebraram a escola poderiam ser consideradas, desse modo, como uma verdadeira propaganda do empenho governamental no âmbito do ensino, cujos primeiros esforços concentraram-se na construção de lugares apropriados para a prática pedagógica, pois até então, o ensino era ministrado em casas comuns, muitas vezes, sem condições ideais para a recepção dos alunos e trabalhos dos mestres (CARVALHO, 1989). A construção dos edifícios escolares, na opinião do professor e Secretário do Interior Paulista à época, Cesário Motta, representou a força de uma idéia elevada de instrução do povo, indicando a altura em que a república brasileira colocava o problema da instrução. Para esse educador, sem bons prédios não seria possível a concretização de boas escolas (SoUZA, 1998).

A arquitetura dos edifícios escolares construídos deveria, como observa Sílvia Wolff (1992 apud CARVALHO, 2003), projetar e divulgar os novos tempos e rumos que se pretendiam imprimir à educação e, para isso, a construção deveria "dar a ver" a escola em seu funcionamento, destacando as práticas educativas adequadas aos preceitos da pedagogia moderna. O espaço escolar, representado pela construção dos grupos escolares no contexto brasileiro, deveria ser engendrado de forma a exercer ações educativas dentro e fora dos seus contornos; considerando tal premissa, a 
concepção arquitetônica das primeiras escolas paulistas deveria aliar a racionalidade econômica e funcional aos padrões estéticos, diferenciando-se assim do período político anterior, no qual poucas ou insignificantes reformas foram realizadas nesse sentido (SOUZA, 1998).

À visão do luminoso templo laico levantado com recursos que o Império havia destinado à construção de uma catedral, contrapunham-se visões tenebrosas da escola na velha ordem: 'casas sem ar e luz, meninos sem livros, livros sem método, escolas sem disciplina, mestres tratados como párias' (CARVALHO, 1989, p.24).

A reforma efetuada por Caetano de Campos (1892), com a finalidade de organizar a escola primária e normal paulista, pode ser considerada um dos exemplos da preocupação dos reformadores com a percepção do povo acerca das transformações na área educacional. As modificações engendradas por esse educador levou, na opinião dos estudiosos do período, às últimas consequências a superioridade da visibilidade. A educação do novo homem, do cidadão republicano, dependia de novos métodos e processos de ensino, cujo domínio realizar-se-ia da experiência em vê-los em execução. Foi para concretizar este intuito que se instituíram as Escolas Modelos, anexas às Escolas Normais, cujo objetivo era o de revelar aos estudantes o mundo novo do ensino intuitivo, influenciar suas práticas de ensino e disseminá-las para os grupos escolares e para as escolas isoladas paulistanas, funcionando, desse modo, como um verdadeiro foco irradiador das luzes (CARVALHO, 1989).

Para fazer ver, a escola devia se dar a ver. Daí os edifícios necessariamente majestosos, amplos e iluminados, em que tudo se dispunha em exposição permanente. Mobiliário, material didático, trabalhos executados, atividades discentes e docentes - tudo devia ser dado a ver de modo que a conformação da escola aos preceitos da pedagogia moderna evidenciasse o Progresso que a República instaurava (CARVALHO, 1989, p.25).

Os locais para a instalação das instituições de ensino e a arquitetura das escolas deveriam reunir o grandioso e o funcional, além de seguir as prescrições da engenharia sanitária. O edifício da Escola Normal da Praça da República (São Paulo - Brasil), por exemplo, foi eleito a célula mater do aparelho escolar paulista e deveria ser o padrão a ser adotado na construção de todos os edifícios escolares. O conjunto escola e praça representou, para a capital, o centro da comunhão cívica, de forma a se exaltarem mutuamente. O prédio escolar indicava para os homens da época a presença dos princípios fundamentais do mundo moderno: civilização, técnica, progresso, laicidade, 
igualdade e democracia. Sua fachada grandiosa e seu interior imponente e transparente almejaram despertar na população os mais íntimos sentimentos de devoção pela república e pela educação (MONARCHA, 1997).

A localização da Escola Normal de São Paulo em uma praça pública - aparentemente predomínio do poder temporal sobre a autoridade espiritual - é indicativa da fusão entre o secular e o religioso, originando uma quase religião cívica, presidida por sacerdotes laicos, a qual se instala e se expande na cultura escolar urbana paulista da virada do século (MONARCHA, 1997, p. 103).

A configuração de uma arquitetura escolar representativa do imaginário da época, segundo Monarcha (1997), seria capaz de, juntamente com um discurso elaborado em estilo eloquente e idealizador proferidos por ocasiões das solenidades, promover a construção de uma imagem de criança valorizada, como a herdeira da República recém-instalada. Ao estado paulista caberia assumir a função de preceptor dos novos, povo e criança, representados como portadores da menoridade intelectual e social, incorporando-os à ordem social, por meio do trabalho e da instrução (MONARCHA, 1997) ${ }^{115}$. A escola se constituía, dessa forma, como a instância privilegiada de uma política ampla, coletiva e contínua de resguardo da população, bem como de promotora de novas formas de socialização e apropriação do espaço escolar.

A nova arquitetura promoveu a expansão regulada das atividades corporais ao incorporar às salas de aula os anfiteatros, a biblioteca, as salas de leitura, o refeitório, os jardins, as 'áreas livres'. Na opinião de quem freqüentou essas instalações, particularmente as crianças mais pobres, a existência desses locais funcionou não como um código de confinamento, mas de reapropriação de espaços de sociabilidade crescentemente sonegados às classes trabalhadoras pelas reformas urbanas que lhes empurravam para os morros ou para a periferia das cidades (NUNES, 2000, p. 388).

Todos os esforços feitos no sentido de organização de um aparato moderno de ensino, fossem eles públicos ou particulares, desde a redação das leis até a construção dos edifícios assumiram divulgação máxima. As festas de inauguração e aniversário, bem como as notícias sobre a compra e doações de terrenos para a construção de escolas, foram noticiadas de maneira recorrente nas últimas décadas do século XIX e nas primeiras do século XX. As formas pelas quais as informações acerca das inaugurações e aniversários das escolas foram veiculadas indicaram o desejo de deixar

\footnotetext{
${ }^{115}$ Em 1934, a Associação Brasileira de Educação organizou a primeira exposição de arquitetura escolar,
} indicando, assim, como este debate perpassa todo o período de constituição do sistema de ensino paulista. 
patente o avanço que vinha sendo alcançado pela nova organização administrativa no campo educacional. Considerados momentos ideais, tal como se afirmava, visava-se divulgar o novo ideário político e consolidar o novo sistema de ensino; à medida que se poderiam demonstrar os esforços idealizados na construção de edifícios públicos, as festas escolares assumiram lugar de destaque:

No dia nove de agosto passado inaugurou-se na cidade de Bragança o grupo escolar criado pelos constantes esforços do distinto inspetor escolar Sr. Raphael de Lima.

A cerimônia da inauguração foi feita com grande regozijo da população, que via naquele ato a garantia de um ensino mais metódico do que se dá nas escolas isoladas.

Parabéns ao povo de Bragança e ao digno inspetor pelo novo melhoramento (A Eschola Pública, 15 de setembro de 1897, p.277).

Além dos momentos de aniversário e inauguração, outras oportunidades podiam ser utilizadas para mostrar e celebrar a escola, como ocorreu na Escola Acadêmica do Porto pelo evento do "divertido S. João". Nos dois dias de festa, "o importantíssimo colégio" foi franqueado ao público, que pôde verificar, ao percorrer os cômodos do prédio, as salas de aula, "mobiliadas com excelente material higiênico e pedagógico" (O Magistério, 12 de julho de 1914, p. 02), os laboratórios, os museus, os dormitórios; enfim, toda a estrutura escolar considerada exemplar pelo autor anônimo da notícia veiculada:

A iluminação era surpreendente e vastíssima; o fogo lindíssimo e ininterrupto.

Nessa ocasião tivemos ensejo de percorrer as dependências do colégio ficando deveras encantado com as salas de aula, mobiliadas com excelente material higiênico e pedagógico, com os amplos dormitórios, com o museu de história natural, com o gabinete de física, com o laboratório de química, todos bem fornecidos e que não servem para vistas, mas para o estudo prático, experimental das disciplinas que respeitam.

É sem dúvida um colégio modelar (O Magistério, 12 de julho de 1914, n. $15 /$ ano 1, p. 02 ).

Nos textos veiculados destacaram-se, além dos elogios feitos à iniciativa de construção e inauguração de prédios escolares, o detalhamento das características dos mesmos, que deveriam ser parâmetros para a construção de outras instituições de ensino. Em Tomar, Portugal, na freguesia de Bezelga, registrou-se com bastante entusiasmo a criação de mais uma escola, destacando-se a "alegria do edifício", bem construído e situado num "local esplendido lavado de ar e por conseqüência favorável 
às crianças que ali irão receber a sua instrução" (A Eschola Primaria, 31 de outubro de 1929, ano II, $2^{\text {a }}$ série, no. 104, p.462). A sessão solene, presidida pelo inspetor chefe da região escolar Sr. Joaquim Tomás, iniciou-se às três horas da tarde com a escola "apinhada de crianças e dos habitantes da localidade"; a primeira parte do programa constou de um discurso no qual o Sr. Joaquim, em breves palavras, enalteceu os esforços de todos que contribuíram para a construção do edifício, destacando o absorvente esforço da Comissão Administrativa. Também felicitou a incansável Junta da Freguesia e louvou a oferta de terreno feita pelo Sr. Valentim. O presidente da comissão administrativa discursou após o inspetor chefe, agradecendo-o a oportunidade de participar do evento e tecendo elogiosas referências ao seu trabalho naquela comunidade. Por fim, incitou os presentes a promoverem à escola o maior auxílio possível a fim de ter continuidade esta "bela obra". Nas palavras do professor Cruz Filipe, em nome de A Escola Primária acerca das iniciativas locais:

(...) largamente à função da Escola, à vantagem da instrução, aos deveres dos pais e dos alunos, lembrando a conveniência da organização de Associações Escolares, sobretudo a dos Amigos da Escola para que a obra ali patente possa continuar com entusiasmo, frutificando cada vez mais" (A Eschola Primaria, 31 de outubro de 1929, ano II, $2^{\text {a }}$ série, no. 104, p.462).

Em Portugal, ao lado das notícias sobre a criação de edifícios próprios ao ato do ensino, destacaram-se outras notas acerca das festas de inauguração de dependências escolares consideradas importantes para o desenvolvimento do ensino, tais como a organização de cantinas e bibliotecas escolares, bem como a criação e os aniversários das Caixas Escolares, instituições de importância indelével para o financiamento escolar. Tais iniciativas foram acompanhadas de adjetivos bastante elogiosos aos realizadores da empresa. Presidiu a inauguração, o Exmo. Sr. Governador Civil, que foi muito saudado pela população presente acerca da obra altamente meritória que vinha produzindo em favor da escola primária. O programa constou de recitações, poesias e cantos que foram executados por algumas alunas que, "com a sua singeleza, emprestaram a graça e a alegria à festa" (idem, p. 313):

No passado domingo a Escola 16 esteve em festa. Foi um dia de regozijo para as crianças, de satisfação para os professores e de compensação justa para todos os que tão dedicadamente se empenharam por levar a cabo obra tão bela e digna de louvor. Bem hajam todos aqueles que não se pouparam a esforços para alcançar a abertura desta Cantina, onde nada falta e onde, doravante todas as 
crianças da Escola 16, sem distinção, recebem diariamente a sua refeição quente num dos intervalos dos trabalhos escolares sendo todas as despesas a cargo da Junta (...) (A Eschola Primaria, 06 de junho de 1929, n. 83, ano II, $2^{a}$ série, p. 313).

As reformas e aparelhamentos das instituições de ensino tornaram-se notícias recorrentes nos periódicos de ensino portugueses, representando a importância que se deu à instrução pelos governantes e pela população local que, mediante o pouco auxílio dado pelo primeiro, se organizou em juntas, para garantir melhores condições para a escolarização das crianças. Tais solenidades almejaram confirmar, junto à população, a ideia sobre a importância "de que é destas iniciativas que o país precisa para progredir e para dispensar às crianças um ambiente de igualdade e conforto que muito contribui para a sua educação" (idem, p. 313), e a sua "compreensão dos deveres de cada um" (A Eschola Primaria, junho de 1929, p. 331). A perfectibilidade do ensino estaria não só na formação de pessoal especializado, na escolha de métodos adequados de ensino, mas também na capacidade dos sistemas de aperfeiçoarem suas "células mater", que eram os prédios escolares.

Iniciativas semelhantes à da Escola 16, foram observadas nas notas dedicadas às Escolas 15 e 71 que, com o auxílio dos diretores, da Junta da Freguesia de Monte Pedral e de Arroios e do Sr. Governador Civil, instalaram as suas cantinas. Mais uma vez, muitas crianças e convidados enchiam a escola, "o vasto claustro", onde tocava a banda do Asilo Maria Pia. A programação da sessão solene constou de alguns discursos, dentre estes, aqueles que expunham o processo de criação das cantinas para o bom êxito do empreendimento educativo, agradecendo ao auxílio da Junta e a presença do Governador Civil na solenidade (A Eschola Primaria, 20 de junho de 1929, n. 85/ ano II $2^{\mathrm{a}}$ série, p. 331).

No ano de 1929, tem-se registrado nas páginas da revista especializada portuguesa, A Escola Primária, a comemoração de inauguração da biblioteca escolar da localidade de Álges, também em Portugal. A solenidade também foi presidida pelo Sr. Governador Civil do Distrito e secretariada pelos Sr. Administrador e Vereador da instrução da Câmara de Oeiras. O programa, elaborado pela "ilustre professora sra. D. Maria Santos Machado", constou de uma fala inicial da professora explicando os seus objetivos ao organizar e fundar a biblioteca, dentre os quais destacaram-se o de proporcionar à criança aquilo a que ela tem direito, no campo moral, intelectual e estético; prestar homenagem a João de Deus e arejar a ideia de um maior 
desenvolvimento da literatura em Portugal. Os discursos de vários outros oradores, pondo em destaque a bela obra que ali se iniciava, foram seguidos por uma conferência sobre a evolução da Literatura Infantil em Portugal, proferida pela Sra. D. Ana de Castro Osório. O hino "A Portuguesa ${ }^{116 "}$ foi cantado pelos alunos e, por fim, a leitura do soneto Camões de João de Deus, por uma criança de sete anos:

\begin{abstract}
A ilustre professora Sra. D. Maria Santos Machado explicou os seus intuitos ao fundar a biblioteca, que foram: proporcionar à criança aquilo a que ela tem direito - no campo moral, intelectual e estético prestar homenagem a João de Deus e arejar a ideia de um maior desenvolvimento da literatura em Portugal. Em seguida o representante do Sr. Ministro da Instrução descerrou a biblioteca que estava coberta com a bandeira nacional e 53 crianças cantaram a Portuguesa. A Sra. D. Ana de Castro Osório fez então uma conferência sobre a evolução da Literatura Infantil em Portugal, pondo em relevo o carinho, a inteligência e o esforço do Sr. Marques Junior, publicando uma obra de muito valor bibliográfico, como o modesto título de Achegas para uma biblioteca infantil, obra única no gênero e onde se vê tudo quanto se fez sobre literatura infantil.

Depois o Sr. Administrador do concelho afixou o $1^{\circ}$ ex-libris da biblioteca a um vol. dos Versos de João de Deus e um pequenito de 7 anos leu o soneto Camões, de João de Deus.

Em seguida falaram ainda vários oradores, pondo em destaque a bela obra que ali se iniciava, encerrando-se depois a sessão que decorreu sempre animada. A biblioteca inaugurou-se com 338 volumes $(A$ Escola Primária, 11 de julho de 1929, n. 88/ ano II $2^{\mathrm{a}}$ série, p. 361).
\end{abstract}

A participação dos convidados "ilustres" era coroada no momento aos quais estes discursavam, mas quando estes não estavam presentes, a tarefa ficava a cargo do diretor ou dos professores do estabelecimento do ensino e, até mesmo, dos alunos devidamente orientados pelos seus mestres. A presença dos dirigentes do ensino não foi uma constante no período, tornando-se cada vez mais escassa com o passar do tempo, sendo considerada pelos mestres como uma falta de interesse do Estado pela educação, como consta, por exemplo, no texto da professora D. Maria Reis, em novembro de 1907, por ocasião da inauguração do Grupo Escolar de São Simão.

Nesse discurso, a professora reclamou da não participação de pessoas ilustres, relembrando que em "um passado que não é remoto", quando se festejava a inauguração de uma "casa de instrução", comparecia o presidente do Estado, reformadores como Cesário Motta e Bernardino de Campos, incitando os professores à luta. A presença dessas pessoas nas festas marcou o que a autora denominou de "período áureo", mas que naquele momento os tempos eram outros e mesmo sem a presença destas pessoas,

\footnotetext{
${ }^{116}$ Hino Nacional de Portugal, elaborado por Henrique Lopes de Mendonça, em 1890.
} 
os professores não deveriam desanimar, já que eram os mais importantes de todos os fatores da educação nacional, nas palavras da professora: "Trabalhais, como o fazeis agora, dando realce e vida a uma instituição moribunda, e a uma classe de funcionários de Estado, que há dilatado prazo se vê órfã das carícias paternais" (Revista de Ensino, novembro de 1907, p. 106). Além de reclamar a pouca atenção dada pelos dirigentes à ocasião festiva da sua escola, cabe destacar que a professora mencionada lecionava em uma escola do interior do Estado de São Paulo, cuja distância e dificuldade de acesso talvez justificassem a ausência de representantes do estado; seu discurso permitiu conceber a celebração como um momento para o fortalecimento da categoria do professorado, uma ocasião na qual, além do reconhecimento do seu trabalho, os mestres presentes poderiam buscar ânimo para seguirem suas carreiras na educação.

O mestre é o mais importante de todos os fatores da educação nacional e não deve abdicar o seu mais nobre privilégio. Mestres são preceptores no sentido mais lato da palavra. A sua missão é tanto de educação moral como de educação intelectual (...)

Trabalhai, como o fazeis agora, dando realce e vida a uma instituição moribunda, e a uma classe de funcionários de Estado, que há dilatado prazo se vê órfã das carícias paternais (Revista de Ensino, novembro de 1907, p. 104-106).

Além da indicação dos nomes dos cidadãos ilustres, os artigos, que na maioria das vezes eram publicados na seção de noticiários das revistas, apresentavam o programa que fora seguido e a atuação dos alunos. Os programas das festas de inauguração e de encerramento do ano letivo se distinguiram das demais comemorações, pela realização da inspeção geral em todos os anos, com a finalidade de saber as reais condições para a abertura e o funcionamento das escolas e se estas estavam desenvolvendo as atividades de ensino de acordo com as regulamentações legais.

Realizou-se a 13 de abril, com a presença do vice-presidente do Estado, Dr. José Alves de Cerqueira Cezar, Diretor Geral da Instrução Publica, Professor Thomaz Galhardo; Secretário do Interior, representado pelo professor Bonilha Junior; e muitas pessoas gradas, a inauguração daquela escola de que é diretora a distinta normalista D. Elisa Rachel de Macedo. Constou a inauguração de inspeção geral em todos os anos; discursos, recitativos e hinos, desempenhados pelos alunos; revelando assim a competência da digna diretora e do pessoal adjunto (...) (A Eschola Publica, junho de 1896, p.160).

Além da descrição do programa e da forma como esse foi executado, no caso das inaugurações de escolas, foi comum, especialmente nos periódicos brasileiros, a 
publicação de fotografias do edifício escolar, além de outras informações sobre a instituição de ensino, como número de alunos do sexo feminino e masculino, número de professores, de salas de aulas, matrículas, entre outras. Outros periódicos, além da fotografia, traziam trechos de notícias publicadas em jornais de ampla circulação acerca destas solenidades. Além disso, existia, como prática para registrar determinado evento nas páginas das revistas de ensino, a transcrição dos discursos pronunciados pelos representantes do Estado e/ou pelos professores da instituição, assim como aconteceram nas comemorações cívicas.

A primeira notícia sobre festa localizada nos periódicos de ensino brasileiros foi publicada em A Eschola Publica, em $1^{\circ}$ de julho de 1893 , mês de início da publicação do periódico, que destacou uma celebração em comemoração ao $3^{\circ}$ aniversário da fundação da Escola Modelo, no dia 20 de junho. Considerada instituição exemplar, a Escola Modelo foi a instituição nuclear da Reforma Caetano de Campos (São Paulo), pela qual se inaugurou a lógica que presidiu a institucionalização do modelo escolar paulista. Nessa escola, anexa a Escola Normal também criada pela reforma, os futuros mestres podiam ver como as crianças eram educadas. Privilegiavase o aprendizado centrado na visibilidade e imitabilidade das práticas pedagógicas; além disso, era responsabilidade das escolas modelos disseminar os métodos de ensino considerados os mais modernos e apropriados, bem como práticas avançadas de organização da vida escolar.

O programa da comemoração realizou-se da seguinte maneira: entrega do retrato do venerando mestre Dr. Caetano de Campos, pelo Sr. Sócrates de Oliveira, distinto aluno da Eschola Normal; $\underline{O}$ trovão, poesia recitada pelas meninas Armelinda Matta e Orchideia Matta, sendo por estas oferecido um lindo bouquet de flores naturais ao Sr. Presidente do Estado; Saudação ao trabalho, pelo menino Nestor Macedo; Filho e mãe poesia recitada pelas meninas Deolinda Coelho e Carmella Stavale; Gotta de Orvalho, recitada pelo menino Jaime de Andrade; Deus, poesia recitada pela menina Irene; No lar, recitada pela menina Maria do Carmo; saudação ao Sr. Ministro do Interior, pela menina Armelinda Matta, que ofereceu-lhe um bouquet de flores naturais, em reconhecimento ao interesse que Sr. Exc. toma pela Eschola Modelo e pela infância paulista (...)

Por fim, falaram eloqüientemente os Drs. Presidente do Estado e Ministro do Interior, animando a mocidade a que cumpram seu dever, para assim terem com justiça o nome de mestres, e de mestres verdadeiros (...) Foram cantados pelas crianças alguns hinos, terminado a festa entre aplausos de todos os assistentes (A Eschola Pública, julho de 1893, p.08). 
$\mathrm{Na}$ referida ocasião, estavam presentes o Senhor Presidente do Estado, o Secretário do Interior, Dr. Cesário Motta, o Sr. Benevides, diretor da Escola Normal, os alunos e suas respectivas famílias. A presença dos representantes do Estado nessas ocasiões garantia a legitimidade ao evento, além do prestígio e o sucesso do festejo escolar. O programa dessa comemoração, transcrito no periódico, foi composto de homenagens aos representantes ilustres presentes e recitação de poesias pelos "melhores" alunos da Escola Modelo. O critério de escolha dos alunos responsáveis pelas homenagens e recitação de poesias, momentos de destaque das solenidades, não pode ser conhecido através da análise das fontes, mas infere-se, a partir dos adjetivos que acompanhavam os nomes dos alunos, que eram estudantes que se destacavam pelas suas notas, pelo comportamento ou por ambos.

A Eschola Publica (1893-1897) não se dedicou exclusivamente à publicação de informações sobre as festas realizadas em São Paulo, mas transcreveu notícias de festas realizadas em outras localidades. Como exemplo, pode-se citar a inauguração de um grupo escolar em Jundiaí, em junho de 1896; aniversário de grupo escolar em Lorena, também no mês de junho de 1896; inaugurações de grupos escolares em Itatiba e em Bragança, ambos na mesma data, em junho de 1896.

No dia nove de agosto passado inaugurou-se na cidade de Bragança o grupo escolar criado pelos constantes esforços do distinto inspetor escolar Sr. Raphael de Lima.

A cerimônia da inauguração foi feita com grande regozijo da população, que via naquele ato a garantia de um ensino mais metódico do que se dá nas escolas isoladas.

Parabéns ao povo de Bragança e ao digno inspetor pelo novo melhoramento (A Eschola Publica, setembro de 1897, p.277).

Artigos mais detalhados sobre o desenvolvimento das festas escolares, como vimos, por exemplo, a do aniversário da "Eschola Modelo" de São Paulo, foram apresentados nas páginas das revistas de ensino, ao lado de outros artigos mais sucintos que visaram apenas noticiar o acontecimento, sem grandes preocupações com o detalhamento do programa do evento e a forma pela qual tivesse sido executado. Este foi o caso da notícia intitulada "Itatiba", publicada no periódico A Eschola Publica, em 15 de julho de 1896, na qual os editores da revista apenas agradeceram o recebimento do convite para assistir a inauguração do grupo escolar, ou ainda, o artigo "Lorena", publicado no mesmo exemplar, no qual a revista destacou o brilhantismo dos festejos escolares comemorativos da data de abertura do grupo escolar "Gabriel Prestes" e afirma que "A última hora, como escrevemos, não podemos fazer a descrição da 
festividade" (A Eschola Publica, junho de 1896, p.159). Essas notícias breves também aconteceram com outros tipos de solenidades, constituindo-se uma das características das notícias acerca das festas publicadas no período.

Composta de um programa distinto das comemorações de aniversário e inauguração das instituições de ensino, mas almejando, assim como as outras celebrações, garantir a visibilidade do sistema escolar paulista, ocuparam lugar de destaque para a sociedade e para os escolares, as festas de encerramento do ano letivo. Organizadas em rituais distintos de acordo com os níveis de ensino (A Eschola Publica, dezembro de 1896, p.423), foram compostas de sessões literárias e musicais, com declamação de poesias e hinos escolares, além da presença de convidados ilustres, geralmente representantes do Estado. Alguns hinos e poesias eram escritos especialmente para determinadas ocasiões, o que contribuiu para delimitar a especificidade de cada data. Como prática diferenciada, as festas relativas ao encerramento do ano letivo apresentaram em seus programas a realização dos exames finais sobre as disciplinas estudadas durante o ano letivo, nos quais os alunos deveriam demonstrar os resultados obtidos em todo o período de estudo e dedicação, bem como a distribuição dos boletins de promoção e prêmios aos melhores alunos.

Os grupos escolares da capital e do interior têm se esmerado no preparo dos festejos para celebrar o encerramento do ano letivo.

Infelizmente por estar já a entrar para o prelo este número não nós é possível dar notícias circunstanciadas dos festejos. Entretanto, o que podemos garantir é que o professorado e alunos se têm esforçado muito para o brilhantismo das festas.

Também tem os mesmos estabelecimentos de ensino organizado exposições de trabalhos que muitos e merecidos elogios tem merecido (A Eschola Publica, dezembro de 1897, p.361).

Os dias dedicados às provas públicas eram momentos importantes para a vida escolar, era um dia de festa, de comemoração, de solenidade ${ }^{117}$, especialmente para os que teriam seus saberes "coroados". A reforma republicana instituiu os dispositivos legais da avaliação como atividade sistemática e contínua no ensino primário, submetendo-a a uma série de regulamentações. O uso da avaliação formal relacionou-se com a estruturação do sistema de ensino no século XIX, baseada na graduação escolar e na necessidade de classificação permanente dos alunos. Os exames nas escolas

\footnotetext{
${ }^{117}$ O Regimento Interno das Escolas Públicas do Estado de São Paulo de 1894 dedicava um capítulo para os exames escolares, e instituiu como prática dos grupos escolares, a distribuição de prêmios e as festas de encerramento do ano letivo.
} 
graduadas tornaram-se rituais de grande projeção pública, representando uma das normas de excelência da escola primária paulista, compartilhada por toda a sociedade: "Para as bancas examinadoras eram convidados políticos e autoridades locais, portanto, uma validação social do ato de classificação de inegáveis consequências políticas e sociais" (SouZA, 1998, p.244). Além disso, os exames eram utilizados como forma de fiscalizar o trabalho pedagógico realizado e controlar o que deveria ser ensinado e aprendido (SOUZA, 1998).

Os exames, as festas de encerramento do ano letivo, as exposições escolares e as datas comemorativas constituem rituais e expressões da inserção da escola no tempo histórico e social. Enquanto práticas simbólicas, permitem evidenciar como a escola primária pode articular práticas educativas com o imaginário sóciopolítico republicano (SOUZA, 1998, p.275).

No Regimento Interno das Escolas Públicas do Estado de São Paulo de 1894 (SoUZA, 1998), constava a implementação dos exames públicos a ser realizados por bancas examinadoras compostas: pelo inspetor do distrito, na função de presidente, dois examinadores pelo inspetor nomeado e pelo respectivo professor da escola ou classe. Ao final do $4^{\circ}$ ano do curso preliminar era distribuída aos alunos atestados de habilitação nas matérias do curso. A classificação dos exames era feita por meio das categorias: distinção, aprovação plena, reprovação ${ }^{118}$.

No trabalho dos exames deveriam ser observadas as seguintes condições: os professores, antes da prova oral, procederiam a um exame geral das matérias lecionadas, devendo versar sobre todas as matérias do programa do curso preliminar. Compreendiam os exames provas escritas, práticas e orais. Escritas, as de ditado, composição de questões práticas de aritmética. Práticas, as provas de caligrafia e desenho, e orais, todas as demais matérias (SoUZA, 1998, p. 243).

Todas as crianças participavam desse ritual, inclusive as que recebiam instrução em casa. Entretanto, o significado do exame era diferente para as distintas escolas existentes no período: para os grupos escolares, os exames ganharam um sentido diferente dos "glamourosos" exames finais das escolas preliminares ou isoladas. O cotidiano escolar, com seus exercícios repetitivos e gradativos em complexidade realizados diariamente, apontava sempre para a fase final, que era a da verificação do aprendizado total por meio do exame. Nas escolas, não se examinaram apenas os conhecimentos, mas igualmente os comportamentos e as aptidões que cada um dos

\footnotetext{
118 Os critérios de classificação foram alterados pelo Decreto 1.253, de 28/11/1904, e passaram a ser expressos em notas: 0 - péssimo; 1 - má; 2 - sofrível, 3 - regular, 4 - boa, 5 - ótima (SoUZA, 1998).
} 
escolares "naturalmente" apresentava (Ó, 2003) no decorrer de todo o período de escolarização.

Os exames obrigaram os alunos a incorporarem o habitus da aquisição de técnicas de observação, análise e avaliação, não apenas da sua própria performance escolar, mas também do seu comportamento. O olhar do outro, do colega, do professor, do público e das autoridades era onipresente e onisciente nessas situações, indicando não somente a ação que perscruta, examina e investiga, mas também, os lugares esquadrinhados e assinalados para os professores, os alunos e a sociedade, no qual cada um deveria assumir uma identidade (FouCAULT, 2004). O estabelecimento das hierarquias escolares foram devedoras dos exames utilizados para organizar as turmas em séries, indicar os melhores e piores alunos e, implicitamente, facilitar a emulação escolar. Incorporados ao calendário escolar, deveriam acontecer sob a responsabilidade do diretor e dos professores e realizarem-se durante todo o ano letivo, e não só no fim do ano, como os deixaram ver as realizações das solenidades públicas.

Se, num primeiro momento, tanto nas escolas preliminares ou isoladas quanto nos grupos e escolas reunidas, os exames tinham a função de avaliar o trabalho efetuado pelo professor - quanto mais crianças fossem aprovadas nos exames finais, melhor seria $\mathrm{o}$ professor - , com a gradativa generalização do modelo instituído pelos grupos, os resultados dos exames passaram a expressar a capacidade, o empenho e a dedicação do aluno, o que não significa a inexistência de menção ao número de alunos aprovados como indicativo do bom trabalho realizado pelo professor (GALLEGO, 2003, p.71-72).

Os exames, de acordo com Chervel (1990), constituíram-se importante aspecto para o estudo da história das disciplinas escolares. Para esse autor, as necessidades de avaliação dos alunos nos exames internos ou externos engendraram dois fenômenos capazes de influenciar o desenvolvimento das disciplinas ensinadas: primeiro foi o da especialização de certos exercícios na sua função de exercícios de controle, como por exemplo, as chamadas orais e os ditados, entre outros; segundo, foi o peso significativo que as provas do exame final exerceram sobre o desenrolar da classe e o desenvolvimento da disciplina. A história dos exames se relacionou a um esforço constante para reaproximar as provas de avaliação das grandes finalidades da disciplina, constituída, em proporções variáveis, de um ensino de exposição, de exercícios, de práticas de motivação e de incitação e de avaliações. Por meio dos exames, formalizaram-se inúmeros códigos da individualidade que permitiram transcrever, e 
introduzir na série, os traços de cada sujeito. Nas escolas, de forma mais acentuada do que em qualquer outra organização social, a figura do exame é ritualizada em um:

(...) jogo de perguntas/respostas/recompensa que reativa os mecanismos de constituição do saber numa relação de poder específica. Desde logo, o sistema de notas, além de garantir a passagem desigual dos conhecimentos, força à comparação perpétua de cada aluno com todos os outros da classe (Ó, 2003, p. 48).

Com o objetivo de garantir a seriedade e a objetividade das provas, o trabalho da banca examinadora, de acordo com Souza (1998), era rigorosamente lavrado em ata, registrado, assinado e documentado. O alto grau de formalização dos exames da época atestava o desejo do Estado em institucionalizá-lo, de forma que a reprovação e aprovação não fossem concebidas como um ato arbitrário do mestre, mas sim, como algo legítimo, atestado publicamente e confirmado pelo mesmo. O auxílio das Câmaras Municipais para os exames demonstrou como este adquiriu um sentido público, ao vincular o poder político às representações valorativas da escola primária. Os exames serviram como forma de propaganda e legitimação da escola pública no meio social; inicialmente propostos pelo Estado, logo foram tomados como um costume e requeridos pela população (SOUZA, 1998).

A festa de encerramento compreendia, pois, uma festa oficial, uma solenidade na qual, reunindo toda a comunidade escolar, as famílias, as pessoas 'gradas' da sociedade, as autoridades e a imprensa, a escola reafirmava sua identidade e o seu valor social. Por isso, nada melhor para divulgar o seu trabalho e o seu prestigio do que o ar solene, grave, formal dessas festas, juntamente com o espetáculo, a encenação realizada pelos próprios alunos - sentido primeiro da existência da escola (SOUZA, 1998, p.253).

Por outro lado, convém destacar que o alto rigor das provas trouxe à tona o problema da evasão escolar, fazendo da instituição dos exames públicos uma das inovações educacionais republicanas, consideradas por alguns, como uma das mais conflituosas e contraditórias do processo de construção da escola primária que se desejava democrática (SouZA, 1998). Ao mesmo tempo em que os republicanos desejavam implementar o projeto educacional de caráter democrático e universalizar a educação popular, essa escola deveria ser austera e rigorosa para ter prestígio e qualidade. Desse modo, os exames, tão difíceis, acabavam por afastar alunos da escola, problema que seria mais veementemente combatido a partir das décadas de 1910 e 1920, quando a questão do nacionalismo colocaria em debate a erradicação do analfabetismo (idem). 
A partir da análise das notícias localizadas sobre o tema não foi possível identificar a realização de exames específicos para cada matéria, nem a regularidade com que esses deveriam acontecer, mesmo porque é conhecido que os sistemas de ensino demoraram um tempo até funcionarem de acordo com todas as leis previstas para as suas organizações. Nessas notícias somente se mencionou a realização dos exames e a entrega dos prêmios aos melhores alunos; os detalhes sobre os conteúdos examinados e o grau de conhecimento dos alunos não eram publicados junto aos comentários sobre as comemorações.

Ao constituírem-se parte das solenidades, os exames escolares tornaram-se "rituais de grande projeção pública", a partir dos quais era possível visualizar as normas de excelência das escolas públicas paulistas. A validação social do ato passava pela presença de políticos e autoridades locais na composição das bancas examinadoras, cujo trabalho deveria ser registrado em ata, assinado e documentado e no acompanhamento das sessões pelos pais e pela população.

$\mathrm{O}$ alto grau de formalização dos exames na época analisada atesta o desejo do Estado de institucionalizar o exame, de forma que a aprovação/reprovação não fosse vista como um ato arbitrário do professor, mas algo legítimo, atestado publicamente e ratificado pelo poder do Estado (SOUZA, 1998, p. 246).

Enquanto necessidade de propaganda e legitimação da escola pública no meio social, subsistiu a prática dos exames públicos. Era no final do ano que o exame adquiria uma peculiar dramaticidade e manifestava conotações especiais, tornando-se verdadeiros rituais da escola pública. De acordo com DaMatta (1990), o rito poderia ser concebido como um dispositivo elementar na transformação de algo natural em social; para isso era necessária uma forma de dramatização. Como dramatizações que eram, as comemorações deveriam apresentar as escolas em seu melhor funcionamento, o que pressupunha, em certas ocasiões, a não realização dos exames com todos os alunos, mas somente com os considerados melhores. Entretanto, apesar de não indicarem a verificação do aprendizado em todos os cursos e todas as disciplinas, mesmo porque isto demandaria um tempo grande que não garantiria o constante interesse e atenção da população presente na festa, foi possível perceber, por meio de um olhar mais atento às etapas dos programas, o desenvolvimento dos alunos e os seus adiantamentos no ensino, especialmente quando eles eram convidados a tomar parte de destaque nas solenidades ou quando receberam alguma distinção escolar. 
Em síntese, as festas de inauguração, aniversário, encerramento do ano letivo e formatura, eram comemorações públicas com duas funções principais: dar visibilidade aos feitos políticos no âmbito educacional e confirmar a importância da escola entre pais, alunos e professores para a sociedade republicana. Nessas ocasiões, pais e comunidade em geral tinham oportunidade de ver a escola em seu funcionamento, não o regular, mas em uma situação distinta, que favorecia este contato, permitindo a observação dos materiais, dos trabalhos realizados, dos recursos disponíveis e até das falhas que deveriam ser suprimidas. Para os professores e equipe escolar, o objetivo era legitimar a instituição escolar como a mais adequada para a formação dos futuros cidadãos por meio da visibilidade da escola em seu momento mais expressivo, que era a comemoração escolar. Já aos alunos caberia a tarefa de demonstrar todo o aprendizado realizado e responsabilizar-se pela divulgação dos saberes escolares no meio social.

Tal como podemos nos referir às culturas escolares (CHERVEL 1990; VINÃo Frago, 1996; Julia, 2001), é conveniente tratar as festas também na sua pluralidade característica de uma cultura festiva. A cultura da escola e seus elementos, como as festas, transformaram-se com o decorrer do tempo, das sociedades, das políticas e até mesmo das finalidades religiosas (JULIA, 2001), sendo que sua repercussão não ficou restrita ao âmbito escolar, formando somente os indivíduos que frequentaram as escolas, mas também penetrou, moldou e modificou a cultura da sociedade global (CHERVEL, 1990). Isso pode ser observado no caso das festas cujo propósito inicial era deixar bem patente para a sociedade o desenvolvimento admirável e real das crianças educadas nas primeiras escolas públicas paulistas e que, depois de algum tempo, teve seu propósito inicial transformado em outros objetivos, como os comerciais que se apresentam hoje. Pode-se atribuir essa alteração no papel das festas à própria assimilação dessas na cultura escolar. 


\section{Considerações Finais}

A festa ajuda a polir os mitos, embora a sua pedagogia não revele

todos os seus sentidos e significados; nem tudo é decodificado como desejam os seus historiadores e organizadores (FELIPE ALVES, 2008, p. 48)

A tese da festa como atividade pedagógica fundamentada na análise do discurso genealógico (FOUCAULT, 2005), buscou, a partir da metáfora da festa-máquina (OzOUF, 1976), reconstituir a proveniência (FouCAUlT, 2005) das suas práticas no período de consolidação dos modelos estatais de ensino. Compostas de múltiplas peças, técnicas e engrenagens, elas representaram o conjunto de forças em movimento e, possivelmente antagônicas, responsáveis pela permanência das mesmas e pela reinvenção constante dos seus usos e funções, de acordo com as necessidades dos contextos sociais e históricos. Se em tempos remotos elas serviram para indicar a ordem da vida social e doméstica, revigorando as forças dos indivíduos por meio da fé, da ruptura das atividades corriqueiras e da dominação da natureza por meio dos rituais, a descontração, a alegria e a desregulação dos comportamentos ao serem transportadas para os contextos educacionais, passaram, assim como a educação escolar, por um processo de normatização e esquadrinhamento, onde todas as suas etapas deveriam ser planejadas e organizadas de acordo com os melhores resultados educativos. As peças, engrenagens e técnicas foram escolhidas de modelos já conhecidos, cuja repetição favoreceria o fascínio do evento e a adesão do povo, mas a partir daquele momento para uma finalidade diferenciada que foi o ensino e a aprendizagem dos indivíduos.

Os exemplos retirados dos estudos realizados em campos do saber como a Antropologia, a Sociologia, a Etnologia e a História Social e Cultural, nos permitiu conhecer, pela recorrência de sua presença, os elementos (peças) que compuseram o fenômeno festivo. As análises do objeto deste estudo realizadas em diferentes áreas indicadas permitiram decompô-la em seus elementos constitutivos, demonstrando como estes foram surgindo uns após os outros, situando-os no conjunto de circunstâncias que os originou e determinando as causas que os suscitaram. Em outras palavras, foi possível compreender o que fez o evento festivo ser o que é, além de reconhecê-lo como expressão cultural nas diversas sociedades. A incursão por trabalhos de diferentes filiações foi importante para vislumbrarmos como as festas escolares recuperaram 
características existentes em outros rituais sociais, como, para citar alguns exemplos, as danças e as músicas, no caso dos povos considerados primitivos, as passeatas e os discursos originários das procissões e sermões religiosos, a partir dos quais foi possível engendrar uma organização do espaço e do tempo social diferenciada.

$\mathrm{O}$ encaixe das peças escolhidas em diferentes manifestações, associado às fundamentações teóricas elaboradas pelos pedagogos representantes do movimento de renovação de ensino, em final do século XIX e início do XX, permitiram a constituição do objeto festa como um dos componentes que passaram a fazer parte da cultura específica da escola e cuja matriz pedagógica, a partir daquele momento, não poderia mais ser desconsiderada. É claro que as comemorações realizadas anteriormente em outros âmbitos sociais também se destacaram pelas suas características educativas, mas de uma forma pouco sistematizada e fundamentada, acreditou-se que era quase óbvio e natural o aprendizado por meio delas. Foi somente a partir do processo de escolarização do fenômeno que esse passou a receber características pedagógicas baseadas cientificamente e por isso instituídas de grande força no contexto educacional.

Ao retomarmos a história das instituições de ensino no Brasil e em Portugal, no contexto indicado, e investigarmos um dos elementos das culturas escolares dos dois países, foi possível identificar aproximações e distanciamentos nas representações e concretizações dos eventos festivos nas duas realidades (NóvOA, 2000; CATANI, 2007). As aproximações puderam ser estabelecidas a partir do momento no qual os dois países assumiram como parte do projeto modernizador da sociedade, o investimento na constituição do aparato estatal e público de ensino e, para demonstrar tais avanços, instituíram comemorações que celebraram a instituição escolar (construção de prédios, inauguração e aniversários de escolas, formaturas e encerramento do ano letivo), ou o aprimoramento destes (criação de cantinas e bibliotecas escolares); ou ainda quando promoveram por meio das festas das árvores, a constituição de um imaginário político e social associado ao regime republicano. As nações serviram-se de uma mesma técnica para alcançar objetivos bastante parecidos que foi o de dar visibilidade ao aparato público de ensino que se constituía e ao regime republicano que almejava legitimidade.

Os distanciamentos ficaram por conta dos temas das solenidades, ou de algumas situações vividas em um país e não no outro, como exemplo, as festas beneficentes com dias específicos para a sua celebração recorrentes no contexto português, os dias cívicos (representativos dos "heróis" nacionais e acontecimentos 
marcantes da história política de cada um dos países) e as de encerramento do ano letivo com a ênfase que foi dada nas escolas brasileiras. Nestes casos, a maquinaria manteve as suas técnicas e engrenagens, mas para finalidades distintas, a partir do que pode ser observado pela análise das fontes escolhidas para o estudo. Entretanto, mais do que aproximações e distanciamentos, a história aqui elaborada deve permitir a construção de sentidos atribuídos às celebrações nas duas realidades.

As finalidades das solenidades ainda se distinguiram pelos propósitos considerados mais externos ao âmbito educacional e a outros mais específicos do contexto educacional. No âmbito dos projetos políticos e sociais, por exemplo, foi possível destacar alguns usos, como disseminar a ideologia republicana; legitimar o modelo de ensino público e estatal; mostrar os avanços do ensino para as sociedades contemporâneas; demonstrar os trabalhos realizados pelos professores com os seus alunos; fiscalizar a concretização das tarefas das escolas no que diz respeito à formação de comportamentos, valores e conhecimentos reconhecidos socialmente, confirmando assim a função panóptica (FOUCAULT, 2005) das festas; definir as hierarquias entre as escolas e a importância de cada uma para o projeto reformador da instrução (especialmente, como vimos, para o caso das escolas isoladas paulistas); permitir discursos reivindicatórios e de críticas às deficiências relativas à estrutura do sistema e ao trabalho do professor.

No contexto escolar, as situações festivas almejaram ensinar por meio da vivência de diferentes conteúdos, valores e ações, concretizando assim, princípios do ensino ativo; favorecer a emulação entre os escolares, construindo hierarquias e a premiação escolar; estimular os dispositivos disciplinares modernos pelo autocontrole e permitir o desenvolvimento da autonomia e da responsabilidade dos alunos corresponsáveis pelas ações preparativas e de execução desses eventos. Sabe-se que os fins sociais, políticos e educacionais assinalados aqui não resumem todas as possibilidades de representações e apropriações permitidas pelas festas, mas somente buscam registrar as mais recorrentes, presentes no corpus documental composto pelos manuais pedagógicos, periódicos de ensino dos dois países e das fotografias, especialmente para o caso brasileiro.

A novidade das comemorações escolares, assim como as outras intervenções estatais que estavam sendo realizadas nos sistemas escolares em finais do século XIX e início do XX, prescindiu de um discurso que justificasse seus usos e potencialidades no ensino, recuperados, nesta tese, por meio de dois registros diferentes, que acabaram por 
se complementar: os textos teóricos dos pedagogos representantes da Escola Nova (Dewey, Claparède, Ferrière, Lourenço Filho, Adolfo Lima, Álvaro Lemos, Émile Planchard e Faria de Vasconcelos) e as prescrições dos manuais pedagógicos, que analisados em conjunto e de forma intricada demonstraram a possibilidade de construção do ideal das festas. Como foi discutido alhures, os manuais pedagógicos tinham como função "fazer as teorias descerem do céu à terra" (GRISI, 1956 apud SILVA, 2005), ou, em outras palavras, tornar as propostas teóricas de organização do ensino mais acessíveis ao universo cotidiano dos professores e foi exatamente este movimento que se inferiu na investigação das festas, quando esses trouxeram prescrições e modelos a serem praticados.

Concebidas como experiências educativas, capazes de atender às necessidades de recreação, os interesses pelos projetos escolares e atividades das crianças, as festas escolares tornaram-se tarefas exemplares da concretização das premissas renovadas de ensino que colocaram o educando no lugar central no processo de ensino e aprendizagem. Por meio delas, os alunos poderiam ter uma atuação mais ativa na concretização do processo de ensino e aprendizagem, responsabilizando-se por determinadas partes dos programas, apresentando os conteúdos curriculares aprendidos durante as aulas nas situações de exames públicos e ainda tendo seus esforços legitimados especialmente os melhores alunos, ao receberem prêmios por essa conduta. Neste sentido, e recuperando a definição do conceito, ainda é possível realizar distinções concernentes às festas das crianças, nas quais elas assumiam a responsabilidade quase total pelo evento, atuando em peças teatrais, declamando textos de suas autorias, realizando homenagens e praticando exercícios físicos, tendo os professores papéis de orientadores e, às festas para as crianças, apresentadas com o propósito do aprendizado por meio da escuta atenta aos discursos dos mestres e dos convidados, ou da beneficência dessas, nas quais a presença passiva ou, até mesmo, a ausência dos escolares, foi possível.

Como oportunidade de verem e serem vistos, alunos e professores, elas tornaram-se oportunidades significativas para incitar o interesse da criança para o aprendizado escolar, reconhecidas como um dos meios auxiliares do ensino e como forma de melhorar o desempenho dos alunos; para o aprendizado do tema e conteúdo do evento que estava sendo comemorado e por fim, para o reconhecimento e estabelecimento do lugar social ocupado pelos estudantes permitido pelas homenagens e provas públicas, apresentando-se, desse modo, como um importante mecanismo de 
disciplinarização e de moralização infantil. A característica disciplinadora das comemorações residiria, inicialmente, no controle externo realizado pelos responsáveis pelo ensino, evidenciado, por exemplo, na indicação das datas, de heróis e de fatos a serem solenizados, bem como nas prescrições descritas nos programas das festas publicados oficialmente por meio de circulares e, de forma mais implícita, na incorporação de regras, saberes e ações escolares associados ao evento pelas crianças. A transposição das festas realizadas nas esferas públicas para o contexto escolar, associadas em algumas situações à livre expressão de paixões, desejos e instintos dos indivíduos, passou por um processo de esquadrinhamento e reajuste aos propósitos do ensino e da disciplina escolar, afastando-a das suas vivências iniciais (por exemplo, pelos povos primitivos). A obediência às regras escolares tornar-se-ia além de um dos condicionantes do sucesso da atividade, uma iniciação ao comportamento, que deveria ser representado socialmente.

Ao assumir tal perspectiva civilizadora, de incutir e regras e comportamentos relevantes para a vida em sociedade, a escola recorreu a diferentes recursos didáticos e, dentre eles, podemos citar o objeto desta tese. Do interior das festas, engendraram-se as estratégias de controle, instauração, preservação e perpetuação de valores, de tradições, de comportamentos existentes ou pretendidos, de disciplinas, de identidades, de hierarquias, entre outros. Aproximar os alunos destas normas, preceitos e saberes escolares, constituiu-se parte do projeto civilizador da escola também presente nas características pedagógicas das comemorações. As festas, como ocasiões que precipuamente associaram-se a ideias de desregulação e espontaneidade, nas escolas adquiriram características disciplinadoras e moralizadoras acentuadas, tornando-se momentos de demonstrações do controle do corpo e da mente dos alunos. O esquadrinhamento disciplinador se fazia presente quando determinava previamente o local de cada um, o papel a ser desempenhado e os diferentes graus de conhecimento esperado, distinguindo os alunos hierarquicamente. Ao seguir programas, dias e ciclos predefinidos, as festas puderam desenvolver os valores da ordem e da regularidade, indicando aos alunos a importância de seguir as regras definidoras das organizações sociais.

As situações festivas reorganizaram os saberes disciplinares, buscando por meio deles, a moralização da infância. Este primeiro elemento da moralização, a disciplina, permitiria que os comportamentos dos alunos, ao penetrarem na "maquinaria escolar" (VAREla, J.; AlVAREZ-URIA, F., 1992), fossem refeitos segundo um código: as 
boas tendências eram reforçadas e transmutadas em espírito de disciplina; as más tendências, transformadas em faltas (FERNANDES, 1994). Boas e más tendências cujas definições poderiam variar entre os autores e professores do período. Como outro elemento pertencente ao conceito de moralidade, de acordo com Fernandes (1994), esteve a vinculação a um grupo social permitido pelas festas, primeiro à categoria estudantes e posteriormente ao conjunto de cidadãos que compuseram a pátria. Nessas ações, hábitos e pensamentos organizados coletivamente seriam capazes de gerar o "gosto da vida coletiva" ligando os alunos aos fins coletivos (FERNANDES, 1994).

Dessa forma, é relevante perceber a potencialidade ritualística de conformação e instauração das festas sociais. Estas, nas suas variantes, foram e são capazes de definir hierarquias e posições sociais; concretizar conceitos abstratos; retomar a cultura; indicar representações sociais legítimas a serem incorporadas; permitir uma nova compreensão do tempo (o calendário escolar, por exemplo) e do espaço social (as instituições escolares, como modelo); foram, considerados, por estes motivos, potentes mecanismos de congregação e de instauração do coletivo. Na sua reminiscência conhecida e segura porque comprovada na história, vislumbravam-se as mudanças para o futuro (projetos). Era um tempo/espaço privilegiado de reunião das diferenças, de composição das figurações sociais, de assembleia coletiva e de sociabilidade que, ao mesmo tempo em que conformavam, estimulavam o homem na sua capacidade de inventar, de imaginar e de usar disfarces para investir contra a resistência do mundo.

As festas escolares, como experiência educativa, prolongaram seus ensinamentos para antes e depois da sua realização, garantindo por meio da participação e atividade do aluno, o efetivo aprendizado tanto dos conteúdos escolares, quanto das normas e dos valores implícitos nos temas de cada festa. Neste sentido, a festa alargavase para antes e depois do próprio ato, de dois modos distintos e complementares: num momento anterior, representado pelo conhecimento que a festa exigia dos modos próprios de organizá-la (previsto nos regulamentos, circulares e experiências anteriores), no estudo dos temas das festas e suas relações com os outros saberes curriculares, bem como o seu significado para a vida escolar e social; após o evento, seu efeito poderia ser percebido na disseminação das notícias nos jornais e periódicos que buscaram traduzir por meio de textos descritivos e bastante elogiosos do ato festivo, e nas lembranças daqueles que delas participaram.

Associados aos conhecimentos dos usos e funções das festas estavam os saberes e fazeres docentes e discentes relacionados às mesmas. Lidar com mais essa 
novidade educacional em um contexto de reestruturação do ensino demandou dos professores e dos alunos um conjunto de conhecimentos e de práticas antes desconsideradas no contexto escolar: saberes concernentes ao funcionamento da máquina festiva e fazeres indicativos dos papéis assumidos pelos professores e alunos. A inserção de uma nova função, de saberes e fazeres associados a essa organização, determinadas legalmente, das festas escolares influenciou de maneira indelével a identidade docente, as representações que possuíam acerca de si e da sua profissão, bem como das instituições de ensino. Tarefas que até então não se faziam presentes no cotidiano das escolas, como preparar grupos de alunos, agora divididos em idade e nível semelhante de conhecimento, participar coletivamente de comemorações, difundir valores cívicos e aqueles referentes a uma nova cultura escolar mediante o cumprimento das propostas preestabelecidas pelas autoridades educacionais foram demandas que alteraram o cotidiano escolar e a profissão docente.

A partir daquele momento, a proposta de ser professor integrou as maneiras ideais de festejar e celebrar, transformando a sua identidade e a sua prática docente. Aos saberes festivos estariam associados, desse modo, a imagem que o mestre desejava demonstrar de si, os resultados escolares verificados no aprendizado dos alunos e, em um âmbito mais geral, da própria profissionalização e dignificação social da atividade docente. As mudanças engendradas em âmbito mundial para a constituição de um modelo escolar, democrático, laico, estatal e público de ensino não se fizeram sem uma constante preocupação acerca do profissional ideal para o contexto escolar que se organizava.

A construção dos conceitos operatórios saberes e fazeres discentes almejou identificar as representações dos conhecimentos e das ações associados aos eventos festivos que deveriam ser conhecidos pelas crianças. Foi possível inferir, considerando as limitações que as próprias fontes impuseram, as formas pelas quais os alunos vivenciaram a atividade festiva, os saberes exigidos para a sua preparação e os conteúdos divulgados nas suas apresentações. Como uma das atribuições das crianças que viveram as escolas públicas na viragem do século XIX para o XX esteve a preparação dos festejos escolares, concebidos nas suas diversas modalidades, tornandose, dessa forma, um dos elementos constitutivos do habitus escolar. Fazer parte e contribuir para a elaboração de uma cultura escolar exigiu das crianças o estabelecimento de um sentido ao trabalho que ali se realizou, das suas regras e dos seus saberes, isto é, a reorganização de um sistema de esquemas de percepção, de 
pensamento, de avaliação e de ação, que permitiram a elas tirar o máximo possível de lucro das tarefas escolares.

Por meio dos programas curriculares que previam as aulas de canto coral, de música e de teatro, os alunos aprendiam saberes a serem apresentados nas manifestações artísticas das comemorações; já em aulas como história e geografia, os motivos das datas históricas selecionadas, a constituição do território nacional e os símbolos que representavam as unidades das nações (especialmente, simbolizadas nas festas da natureza), os heróis, os acontecimentos históricos que, solenizados, compuseram a memória da nação; em língua portuguesa, ou em português, podiam produzir os textos das homenagens, os discursos e os poemas que seriam declamados. No ensino do civismo e da moral, a apresentação dos valores e comportamentos do ideal de cidadão a ser perseguido por toda a população; a ginástica e os exercícios militares eram aulas que facilitariam o desempenho nos desfiles, jogos e torneios que poderiam constar dos programas das festas, e os desenhos e os trabalhos manuais seriam recomendados como forma de reconhecimento nas exposições de final de ano. Enfim, além do aprendizado dos conteúdos oficiais, porque discriminados nos currículos escolares, foi possível identificar outros "escondidos", no âmbito dos quais se destacaram dois saberes discentes que favoreceram a regularidade do funcionamento da escola e dos seus rituais: aprender, por meio da avaliação ou outros tipos de reforço, a satisfazer as expectativas dos professores e dos colegas, e dos colegas para lhes obter estima, elogios ou outras formas de recompensa e premiação e aprender a viver em uma sociedade hierarquizada e estratificada.

Por fim, e como possibilidades de investigações para outros, a retomada das características educativas das festas, não somente para os educandos, mas para os professores, pais e comunidade presentes, corroboraram a tese da festa pedagógica, diferentes de outras por afastarem-se das características iniciais dos primeiros rituais festivos registrados na história da humanidade. Com a sua programação, previamente definida pelas autoridades educacionais, ensaiada e apresentada pelos mestres e alunos não existiu espaços para erros, nem improvisações, mas a execução mais próxima possível da perfeição; afinal, toda a vida escolar, no seu melhor funcionamento, deveria ser apresentada pelo dispositivo festivo. Entretanto, seria um equívoco dizer que a alegria, o divertimento e a liberdade estavam totalmente distantes das festas escolares: pois como toda celebração, estes elementos foram constitutivos e definidores do evento na escola com a diferença de que nesse ambiente estes aspectos deveriam ser 
controlados e garantidos na certa medida da identificação do conceito, ou seja, para que esses eventos pudessem ser reconhecidos facilmente.

A tese apresentou uma das possibilidades de escrita da história das festas escolares, existem outras, que com certeza podem constituir-se em projetos para tempos, locais e sujeitos diferentes... 


\section{Referências bibliográficas}

\section{Manuais de ensino:}

AGUAYO, A. M. Didática da escola nova. Penna \& Ávila (tradução). Biblioteca Pedagógica Brasileira, Atualidades Pedagógicas, Série III, Vol. XV. São Paulo: Companhia Editora Nacional, 1935.

TOLEDO, João (Assistente técnico do ensino do Estado de S. Paulo). Escola Brasileira (Desenvolvimento do programa de pedagogia em vigor nas escolas normaes). São Paulo: Livraria Liberdade, $3^{\text {a }}$. ed. (revista e ampliada), 1932.

NÉRICI, Imídeo Giuseppe. Introdução à Didática Geral (Dinâmica da Escola). Brasil/Portugal: Editora Fundo de Cultura, 1960.

SILVA, Ruth Ivoty Torres da (Auxiliar técnico do Centro de Pesquisas e Orientação Educacionais da Secretaria de Educação e Cultura do Rio Grande do Sul). A escola primária rural. Rio de Janeiro/Porto Alegre/ São Paulo: Editora Globo, 2a . edição, 1957.

MATTOS, Luiz Alves de (Catedrático de Didática Geral e Especial e diretor do Colégio de Aplicação da Faculdade Nacional de Filosofia da Universidade do Brasil). Sumário de Didática Geral. Rio de Janeiro: Gráfica Editora Aurora, 3ª edição, 1960.

AFFREIXO, José Maria da Graça, FREIRE, Henrique (coords.). Elementos de Pedagogia para servirem de guia aos candidatos ao Magistério Primário. Lisboa: Livraria Ferreira, $4^{\mathrm{a}}$ edição, 1875.

PLANCHARD, Émile (professor extraordinário da Universidade de Coimbra, doutor em Ciências Pedagógicas. A Pedagogia Escolar contemporânea - Bases Orientações - Aspectos. Coimbra: Coimbra Editora Ltda., 1942.

LOUREIRO, Francisco de Sousa (Professor efetivo dos liceus e Diretor da Escola do Magistério Primário de Coimbra). Lições de Pedagogia e Didática Geral. Edição do Autor, 1950.

VIANA, Mario Gonçalves. Pedagogia Geral. Porto: Livraria Figueirinhas, $4^{\mathrm{a}}$ edição, 1960, $1^{\text {a }}$ edição 1946.

LAGE, Bernardino da Fonseca. Didáctica Geral da Escola Moderna - Segundo os atuais programas das Escolas do Magistério Primário. Porto: Edição de J. Reis \& Silvas, Ltda., 1945. 
COELHO, J. Augusto. Noções de Pedagogia Elementar, coordenadas, em harmonia com o programa oficial, para uso dos alunos das escolas normais e de habilitação para o magistério primário. Liboa: Livraria Moderna - Editora, 1903.

COELHO, F. Adolpho. Questões Pedagógicas II - O plano geral do ensino público. Separata de “O Instituto", vol. 58. Coimbra: Imprensa da Universidade, 1911.

\section{Autores:}

AMARAL, Rita de Cássia de Mello Peixoto. Festa à brasileira: significados do festejar, no país que "não é sério". Tese de Doutorado. São Paulo: FFLCH-USP, 1998.

ARIÈS, Philippe; DUBY, Georges (dir.). História da Vida Privada - Volumes 2, 3, 4 e 5. Portugal: Edições Afrontamento, 1990.

AZANHA, José Mário Pires. Cultura escolar brasileira: um programa de pesquisas. Revista USP, dez-fev / 1990-1991, p. 65-69.

BARROS, Marcelo. O divino segredo da festa. In: BARROS, Marcelo (org) A festa na vida: significado e imagens. Rio de Janeiro: Petrópolis: Vozes, 2002, p. 59-70.

BARTHES, Roland. O óbvio e o obtuso: ensaios críticos III. Rio de Janeiro: Editora Nova Fronteira, $2^{\mathrm{a}}$ ed, 1990, p. 09-61.

BARTHES, Roland. O rumor da língua. São Paulo: Martins Fontes, 2ª ed., 2004.

BENJAMIN, Walter. Pequena História da Fotografia. KOTHE, Flávio (org.) Walter Benjamin - Sociologia. São Paulo: Editora Ática, 1985, p. 219-241.

BERKENBROCK, Volney J. A festa nas religioes afro-brasileiras - A verdade torna-se realidade. In: PASSOS, Mauro. (org) A festa na vida: significado e imagens. Rio de Janeiro: Petrópolis: Vozes, 2002, p. 191 - 221.

BITTENCOURT, Circe. As "Tradições Nacionais" e o Ritual das Festas Cívicas. In: PINSKY, J. NADAI, E. et al. O ensino de história e a criação do fato. São Paulo: Contexto, 1988, p. $43-73$.

BONTEMPI, Bruno. História da Educação Brasileira: o terreno do consenso. Dissertação de Mestrado. São Paulo: Pontifícia Universidade Católica, 1995.

BOTO, Carlota. Ler, escrever, contar e se comportar: a escola primária como rito 
do século XIX português (1820-1910). Tese de Doutoramento. São Paulo: FFLCH USP, 1997.

BOTO, Carlota. Aprender a ler entre cartilhas: civilidade, civilização e civismo pelas lentes do livro didático. Educação e Pesquisa, São Paulo, v.30, n.3, set./dez. 2004, p. 493-511.

BOTO, Carlota. A racionalidade escolar como processo civilizador: a moral que captura almas. In: Revista Portuguesa de Educação, vol. 23, núm. 2, 2010, pp. 35-72.

BOTO, Carlota. Instrução Pública e Projeto Civilizador: o Século XVIII como Intérprete da Ciência, da Infância e da Escola. Tese de Livre-Docência. São Paulo: FEUSP, 2011.

BOURDIEU, Pierre. Coisas Ditas. São Paulo: Brasiliense, 1990.

Razões Práticas: sobre a teoria da ação. São Paulo: Papirus, 1996.

Os usos sociais da ciência - por uma sociologia clínica do conhecimento científico. São Paulo: Unesp, 2004.

A escola conservadora: as desigualdades frente à escola e à cultura. In: NOGUEIRA, Maria Alice e CATANI, Afrânio Mendes (orgs.). Escritos de Educação. Rio de Janeiro: Ed. Vozes, 1998, p. 41-69.

BRANCO-VASCO, António et al. A vivência do sagrado. Coordenação do Núcleo de Psicologia Transpessoal da Faculdade de Psicologia e de Ciências da Educação da Universidade de Lisboa. Lisboa: Hugin Editores, 1998.

BRANDÃO, Carlos Rodrigues. O Divino, O Santo e A Senhora. Rio de Janeiro: Campanha de Defesa do Folclore Brasileiro, 1978.

BURKE, Peter. A Escola dos Annales (1929-1989): a Revolução Francesa da Historiografia. São Paulo: UNESP, 1991.

BURKE, Peter. Abertura: a nova História, seu passado e seu futuro. In: BURKE, Peter (org.), tradução de LOPES, Magda. A Escrita da História: novas perspectivas. São Paulo: Editora da Universidade Estadual Paulista, 1992, p.7-37.

BURKE, Peter. Como confiar em fotografias. Folha de São Paulo, 4 de fevereiro de 2001, p. 13-14.

CANDEIAS, António. Educar de outra forma: a escola oficina no. 1 de Lisboa 1905-1930. Lisboa: Instituto de Inovação Educacional, 1994. 
CANDEIAS, António; Nóvoa, António e FIGUEIRA, Manuel Henrique. Sobre a Educação Nova: cartas de Adolfo Lima à Álvaro Viana de Lemos (1923-1941). Lisboa: Educa, 1995.

CARDIM, Carlos A. Gomes. As comemorações cívicas e As Festas Escolares. São Paulo: Augusto Siqueira \& C., 1916.

CARDOSO, Carlos Augusto de Amorim. Festas e marchas do Lyceu Paraybano: vivas para a cidade. In: Anais do VI Congresso Luso-Brasileiro de História da Educação. Minas Gerais, p. $4463-4472$.

CARVAlHO, José Murilo de. A formação das almas. São Paulo: Companhia das Letras, 1990.

CARVALHO, José Sérgio. Podem a ética e a cidadania ser ensinadas? In: CARVALHO, José Sérgio (org). Educação, cidadania e direitos humanos. Petrópolis, RJ: Vozes, 2004, p. 85-105.

CARVALHO, Luís Miguel ; CORDEIRO, J. F. P. Brasil-Portugal nos circuitos do discurso pedagógico especializado (1920-1935) - Um estudo histórico-comparado de publicações de educação. Lisboa: Educa, 2002, 71 p.

CARVAlHO, Marta Maria Chagas de. A escola e a República. São Paulo: Ed. Brasiliense: $1^{\circ}$ ed., Col. Tudo é História, 1989.

CARVALHO, Marta Maria Chagas de. Por uma história cultural dos saberes pedagógicos. In: SOUSA, Cynthia Pereira de; CATANI, Denice Barbara (orgs.). Práticas Educativas, Culturas Escolares, Profissão Docente. São Paulo: Escrituras, 1998, p. 31-40.

CARVALHO, Marta Maria Chagas de. A caixa de utensílios e a biblioteca: pedagogia e práticas de leitura. In: HILSDORF, Maria Lúcia; VIDAL, Diana Gonçalves. Brasil 500 anos: tópicas em história da educação. São Paulo: EDUSP, 2001, p. 137 - 167.

CARVALHO, Marta Maria Chagas de. A escola e a República e outros ensaios. Bragança Paulista: Editora Universitária São Francisco e CDAPH, Estudos CDAPH (Série Historiografia - Centro de Documentação e Apoio à Pesquisa em História da Educação), 2003, p. 69 - 101.

CASPARD, Pierre. A escola, a família e o Estado: uma aproximação histórica de suas relações. Bastos, M. H. C (tradução). In: História da Educação - RHE, v. 15, n. 34, Maio/ago. 2011, p. 10-21. 
CATANI, Denice Barbara. Educadores à meia luz: um estudo sobre a Revista de Ensino da Associação Beneficente do Professorado Público de São Paulo. Tese de Doutorado. São Paulo: FEUSP, 1989.

CATANI, Denice Barbara. Informação, Disciplina e Celebração: Os Anuários do Ensino do Estado de São Paulo. Revista da Faculdade de Educação da USP, São Paulo, v. 21, n. 2, 1995, p. 9-30.

CATANI, Denice Barbara; GODINHO LIMA, Ana Laura. Vigilância e Controle: Os Anuários do Ensino do Estado de São Paulo e a história do trabalho docente no Brasil (1907 - 1937). In: Educação em Revista: A Imprensa Periódica e a História da Educação. São Paulo: Escrituras, 1997, p. 155-172.

CATANI, Denice Barbara. Metáforas da Iluminação: observações acerca do estudo da história da educação republicana. In: SOUSA, Cynthia Pereira de (org.). Processos, Práticas e Saberes. São Paulo: Escrituras, 1998, p. 43-52.

CATANI, Denice Barbara e SOUSA, Cynthia Pereira de. (orgs.). Imprensa Periódica Educacional Paulista (1890-1996). São Paulo: Plêiade, 1999.

CATANI, D. B.; VICENTINI, Paula Perin (Orgs.). Formação e autoformação: saberes e práticas nas experiências dos professores. São Paulo: Escrituras, 2006.

CATROGA, Fernando. Nação, mito e rito - religião civil e comemoracionismo (EUA, França e Portugal). Museu do Ceará/Secretaria da Cultura do Ceará/Edições Nudoc: Departamento de História, 2005.

CATROGA, Fernando. O republicanismo em Portugal - da formação ao 5 de outubro de 1910. Lisboa: Editorial Notícias, $2^{a}$ edição, 2000.

CHAMOM, Carla Simone. Festejos Imperiais: Festas Cívicas em Minas Gerais (1815 -1845). Bragança Paulista: Editora da Universidade São Francisco, 2002.

CHARTIER, Roger. Por uma sociologia histórica das práticas culturais. In: A história cultural: entre práticas e representações. Rio de Janeiro: Bertrand Brasil, 1990.

CHERVEL, André. História das disciplinas escolares: reflexões sobre um campo de pesquisa. Teoria \& Educação, nº 2, 1990, p. 177- 229.

CHOPPIN, Alain. História dos livros e das edições didáticas: sobre o estado da arte. In: Educação e Pesquisa, São Paulo, v. 30, n. 3, p. 549-566, set./dez. 2004. 
CHOUCAIR, Aline. Práticas escolares nas festividades da "Semana da Pátria" e "Dia do Trabalho" em Minas Gerais (1937-1945). Atas do Congresso Brasileiro de História da Educação, Curitiba: 2004, p.01-11.

CINTRA, Assis. Alma Brasileira. Obra aprovada pela Diretoria da Instrução Pública do Estado de São Paulo. São Paulo: Cia. Melhoramentos de São Paulo (Weiszflog Irmãos Incorporado), $5^{\mathrm{a}}$ ed., s/d.

CLAPARÈDE, E. A Educação Funcional. São Paulo: Companhia Editora Nacional, Biblioteca Pedagógica Brasileira, Atualidades pedagógicas, Série III, Vol. IV, 1933.

CLAPARÈDE, Eduardo. A escola sob medida. Coimbra: Tipografia Reis Gomes, 1930.

COELHO, Maricilde Oliveira. A escola primária no Estado do Pará (1920 - 1940). Tese apresentada ao Programa de Pós-Graduação da FEUSP. São Paulo: FEUSP, 2008.

CONDORCET. Cinco memórias sobre a instrução pública. São Paulo: Ed. Unesp, 2008.

COUSINET, Roger. A formação do educador e A pedagogia da aprendizagem. Trad. e notas de Luiz Damasco Penna e J. B. Damasco Penna. São Paulo: Editora Nacional e Editora da USP, 1974.

CRESPO, Jorge. A história do corpo. Lisboa: Difel, Coleção Memória e Sociedade, 1990.

DAMATTA, Roberto. Carnavais, Malandros e Heróis - Para uma sociologia do dilema brasileiro. Rio de Janeiro: Editora Guanabara, 5ª edição, 1990.

DEL PRIORE, Mary. Festas e Utopias no Brasil Colonial. São Paulo: Brasiliense, 2000.

DETIENNE, Marcel. Comparar o incomparável. São Paulo: Idéias \& Letras, 2004, p. 45- 67.

DEWEY, J. Democracia e Educação - $2^{\text {a }}$ Edição - São Paulo: Companhia Editora Nacional, Coleção Atualidades Pedagógicas, 1952.

DEWEY, J. Vida e Educação - $5^{\text {a }}$ Edição - São Paulo: Companhia Editora Nacional, Coleção Atualidades Pedagógicas, 1959. 
Dora Lice. O calvário de uma professora. 1927

DURKHEIM, Émile. As formas elementares da vida religiosa: o sistema totêmico na Austrália. São Paulo: Martins Fontes, 1996.

DUVIGNOUD, Jean. Festas e civilizações. FONTENELLE, L. F. Raposo (tradução e notas). Rio de Janeiro: 1983.

FARIA FILHO, Luciano Mendes. "Dos pardieiros aos palácios": forma e cultura escolares em Belo Horizonte (1906/1918). Tese de doutorado. São Paulo: FEUSP, 1996.

FARIA FILHO, Luciano Mendes de. Instrução elementar no século XIX. In: FARIA FILHO, Luciano Mendes de; LOPES, Eliane Marta Teixeira; VEIGA, Cynthia Greive (orgs.). 500 anos de Educação no Brasil. Belo Horizonte: Autêntica, 2003, p. 135 150 .

FARIA FILHO, Luciano Mendes; GONÇALVES, Irlen Antônio; PAULILO, André Luiz; VIDAL, Diana Gonçalves. A cultura escolar como categoria de análise e como campo de investigação na história da educação brasileira. Educação e Pesquisa São Paulo, v. 30, n. 1, jan - abr/2004, p. 139-159.

FELIPE, José Lacerda Alves. Festa e Poder Político. In: Espaço e Cultura, UERJ, RJ, no. 23, jan./jun/ de 2008, p. 43-52.

FERNANDES, Heloísa. Sintoma social dominante e moralização infantil: um estudo sobre a educação moral em Émile Durkheim. São Paulo: EDUSP, 1994.

FERNANDES, Rogério. A história da educação no Brasil e em Portugal: caminhos cruzados. In: Revista Brasileira de Educação, Jan/Fev/Mar/Abr 1998 n. ${ }^{\circ}$ 7, p. 5 -18.

FERREIRA, F. P. Pinto. Algumas Notas Pedagógicas. Lisboa: Casa Portuguesa, 1916.

FERREIRA, Pedrosa. Festa na escola - teatros - monólogos. Porto: Edições Salesianas, 1990.

FERRIÈRE, Adolphe. A Escola Ativa. Porto: Editora - Educação Nacional de António Figueirinhas, 1934.

FONSECA, Thaís Nívia de Lima e. O herói nacional para crianças: produção e circulação de imagens de Tiradentes na escola primária brasileira. Anais da $\mathbf{2 5}^{\mathbf{a}}$ Reunião Anual da Associação Nacional de Pós-Graduação e Pesquisa em Educação: Educação: manifestos, lutas e utopias. Caxambu: ANPED, 2002. v. 1. p. 01-17. 
FOUCAULT, Michel. A arqueologia do saber. Rio de Janeiro: Forense Universitária, $7^{\mathrm{a}}$ edição, 2004.

FOUCAULT, Michel. Nietzsche, a genealogia e a história. In: Microfísica do poder. São Paulo: Graal, 2005.

FOUCAULT, Michel. A Ordem do Discurso. São Paulo: Edições Loyola, $12^{a}$ edição, 2005.

GALLEGO, Rita de Cássia. Uso(s) do tempo: a organização das atividades de alunos e professores nas escolas primárias paulistas (1890-1929). Dissertação de Mestrado. São Paulo: FEUSP, 2003.

GALLEGO, Rita de Cassia. Tempo, temporalidades e ritmos nas escolas primárias públicas em São Paulo: heranças e negociações. Tese de Doutoramento. São Paulo: FEUSP, 2008.

GALlEGO, R. C. ; CORREIA, Antonio Carlos Luz . Escolas públicas primárias em Portugal e em São Paulo: olhares sobre a organização do tempo escolar (1880- 1920). $1^{\mathrm{a}}$. ed. Lisboa: EDUCA, 2004. v. 1. 37 p.

GINZBURG, Carlo. Mitos, emblemas e sinais: morfologia e história. São Paulo: Cia. Das Letras, $2^{a}$ edição, 1990.

GONDRA, J. G. "Medicina, Higiene e Educação Escolar". In: Eliane Marta Teixeira Lopes; Luciano Mendes de Faria Filho; Cynthia Greive Veiga. (Org.). 500 anos de Educação no Brasil. Belo Horizonte: Autentica, 2003, v. 1, p. 519-550.

GVIRTZ, Silvina. Alcances y limites de la investigación en la historia de la educación comparada. História da Educação, vol. 5, no. 10, set. 2001, p. 17-30.

HILSDORF, Maria Lúcia Spedo. O aparecimento da escola moderna: uma história ilustrada. Belo. Horizonte: Autêntica, 2006.

JORGE, Ana Maria; RODRIGUES, Ana Maria; GOUVEIA, António Camões; FERREIRA, António Matos; BARBOSA, David Sampaio; LIMA, José da Silva; THOMAZ, Luís Filipe; FONTES, Paulo F. Oliveira; RODRIGUES, Samuel (coordenadores). Dicionário de História Religiosa de Portugal - centro de estudos de história religiosa da Universidade Católica Portuguesa. Direção de Carlos Moreira Azevedo. Volume C-I. 4 Vols. Lisboa: Círculo de Leitores, 2000-2001, p. 251- 263.

JULIA, Dominique. A cultura escolar como objeto histórico. Revista Brasileira de História da Educação, n. 1, jan.-jun/2001, p. 09-43. 
JUNIOR, Francisco Oliveira. Festas Escolares. São Paulo, s.d.

KOSSOY, Boris. O relógio de Hiroshima: reflexões sobre os diálogos e silêncios das imagens. Revista Brasileira de História, São Paulo, v.25, nº 49, 2005, p. 35- 42.

KUHLMANN, Moysés. As grandes festas didáticas: a educação brasileira e as exposições internacionais (1862-1922). Bragança Paulista: Editora da Universidade São Francisco, 2001.

LAWN, Martin. Os professores e a fabricação de identidades. In: NÓVOA, António, SCHRIEWER, Jürgen. A difusão mundial da escola: alunos, professores, currículo, pedagogia. Lisboa: Educa, 2000.

LEAL, Elisabete da Costa. O Calendário Republicano e a Festa Cívica do Descobrimento do Brasil em 1890: versões de história e militância positivista. HISTÓRIA, SÃO PAULO, v. 25, n. 2, p. 64-93, 2006.

LE GOFF, Jacques. Memória. Enciclopédia Einaudi, vol.1 Memória/História, 1990, p.11-50.

LEMOS, Álvaro de. (Professor da Escola Normal de Coimbra). A educação Nova no Congresso de Locarno e na reunião da cidade de Genebra do Centro Internacional de Educação. Lisboa: "Seara Nova", 1928.

LÉVI-STRAUSS, Claude. Mito e significado. Lisboa: Edições 70, 1978.

LIMA, Adolfo. O Teatro na Escola - comunicação feita perante a Sociedade de Estudos Pedagógicos de Lisboa na sessão de 08 de abril de 1914. Lisboa: Guimarães \& C. Editores, 1914.

LIMA, Adolfo. Educação e Ensino - Educação Integral. Lisboa: Guimarães \& Cia. Editores, 1914.

LIMA, Adolfo.Metodologia. Lições de Metodologia especial - Processologia professadas na Escola do Magistério Primário de Lisboa - Vol. II. Lisboa: Livraria Ferin Torres \& Cia., 1932.

LOURENÇO FILHO, M. B. Introdução ao estudo da Escola Nova. São Paulo: Edições Melhoramentos, $8^{\text {a }}$ edição, 1963.

LOVISOLO, Hugo. A Memória e a Formação dos Homens. Estudos Históricos. Rio de Janeiro, vol 2, n. 3, 1989, p. 16-28. 
LUGLI, Rosário Genta. O trabalho docente no Brasil: o discurso dos Centros Regionais de Pesquisa Educacional e das entidades representativas do magistério (1950-1971). Tese de Doutorado. São Paulo: FEUSP, 2002.

MAGALHÃES, Beatriz Ricardina de. O povo e a festa. In: PASSOS, Mauro. (org) A festa na vida: significado e imagens. Rio de Janeiro: Petrópolis: Vozes, 2002, p. 95112.

MATOS, Sérgio Campos. Problemas de Instrução Pública no Portugal do século XIX. In: SOUZA, C. P. de e CATANI, D. B. Práticas educativas, culturas escolares, profissão docente. São Paulo: Escrituras, 1998, p. 151 - 160.

MAUSS, Marcel. Ensaio sobre a dádiva. Introdução de Claude Lévi-Strauss. Lisboa: Edições 70, 1988.

MONARCHA, Carlos. Arquitetura escolar republicana: a escola normal da praça e a construção de uma imagem de criança. In: FREITAS, Marcos Cezar de. História Social da Infância no Brasil. São Paulo: Cortez Editora, 1997, p. 97-136.

MORAES, Dislane Zerbinatti. Literatura, memória e ação política: uma análise de romances escritos por professores. Dissertação de Mestrado. São Paulo: FEUSP, 1996.

MORAES, Dislane Z. Fontes e objetos históricos no ensino de história da educação: os lugares do texto literário. Anais do Congresso Luso-Brasileiro de História da Educação, 2006, p. 1041-1049.

MORAES, Dislane Zerbinatti. A modernidade pedagógica no discurso médico do século XIX. In: Anais do III Congresso Brasileiro de História da Educação: A Educação em Perspectiva Histórica. Paraná: Pontífice Universidade Católica do Paraná: Sociedade Brasileira de História da Educação, 2004, CD-ROM. p. 1-10

NAGLE, Jorge. A Educação na Primeira República. In: FAUSTO, Boris (org.), O Brasil Republicano. Rio de Janeiro: Difel, 1978, p. 261-291.

NAGLE, Jorge. História da educação brasileira: problemas atuais. Em Aberto, ano 3, n. 23, set-out/ 1984, p.27-29.

NÓVOA, Antonio. A República e a escola das intenções generosas ao desengano das realidades. In: Revista Portuguesa de Educação, 1988, 1 (3), 29 - 60.

NÓVOA, António. Os professores e as histórias da sua vida. In: NÓVOA, António (org.).Vidas de Professores. Porto: Porto, 1992. 
NÓVOA, Antônio. Perspectivas de Renovação da História da Educação em Portugal. In: NÓVOA, A. e BERRIO, J. (orgs), A História da Educação em Espanha e Portugal. Lisboa: Sociedade Portuguesa de Ciências da Educação, 1993, p. 11-20.

NÓVOA, Antonio. Uma educação que se diz nova. In: CANDEIAS, A. et al. Sobre a Educação Nova: cartas de Adolfo Lima a Álvaro Viana de Lemos. Lisboa: EDUCA, 1995, p. 25-41.

NÓVOA, Antonio (org.). A imprensa de educação e ensino. Repertório analítico (séculos XIX - XX). Direção de António Nóvoa. Lisboa: Instituto de Inovação Educacional, 1993.

NUNES, Clarice. (Des)encantos da modernidade pedagógica. In: LOPES, Eliana Marta Teixeira; FARIA FILHO, Luciano Mendes; VEIGA, Cynthia Greive (orgs.). 500 anos de educação no Brasil. Belo Horizonte: Autêntica, 2000, p. 371-398.

Ó, Jorge Ramos do. Poder-saber-querer: os terrenos disciplinares da alma e do autogoverno no primeiro mapa das ciências da educação (1879-1911). Revista Brasileira de História da Educação, no 12, jul-dez/2006, p.11-30.

Ó, Jorge Ramos do. O governo de si mesmo: modernidade pedagógica e encenações disciplinares do aluno liceal (último quartel do século XIX - meados do século XX). Lisboa: EDUCA, 2003.

Ó, Jorge Ramos do. Os Terrenos Disciplinares da Alma e do Self-government no Primeiro Mapa das Ciências da Educação (1879-1911). In: SÍSIFO, número 1, setembro de 2006, p. 127-138.

Ó, Jorge Ramos do; CARVALHO, Luís Miguel. Emergência e circulação do conhecimento psicopedagógico moderno (1880-1960) - Estudos comparados Portugal - Brasil. Lisboa: Educa, 2009.

OLIVEIRA, Lúcia Lippi. As festas que a República manda guardar. Estudos Históricos. Rio de Janeiro, vol. 2, n. 4, 1989, p. 172-189.

OZOUF, Mona. A festa: sob a Revolução Francesa. In: LE GOFF, Jacques; NORA, Pierre. História: novos objetos. Rio de Janeiro: Francisco Alves, 1976, p. 216-232.

PASSOS, Mauro. (org) A festa na vida: significado e imagens. Rio de Janeiro: Petrópolis: Vozes, 2002. 
PASTOR, Raimundo. Alegrias, agruras e tristezas de um professor. Recordações de Xiririca, Itanhaém, Iporanga e Vila Bela de 11-07-1919 a 5-1926. São Paulo: composto e impresso na Gráfica São José, 1970.

PEREIRA, Sylvie Gonçalves. A parte recreativa da festa: o papel e funções das festas escolares no primeiro ciclo do Ensino Básico do ponto de vista pedagógico, social, moral, religioso e político na formação integral do aluno e da comunidade no Distrito de Bragança no início do século XX até a década de 1960. Mestrado em Ciências da Educação, área de especialização em História da Educação. Universidade de Lisboa: Faculdade de Psicologia e de Ciências da Educação: 2006.

PERRENOUD, Philippe. Ofício de aluno e sentido do trabalho escolar. Porto: Porto Editora, 1995.

PINTASSILGO, Joaquim Religiosidade cívica republicana - o exemplo da festa da árvore. Atas do II Congresso Luso-Brasileiro de História da Educação. São Paulo: FEUSP, 1998, p. 448-455.

POMPÉIA, Raul. O Ateneu. São Paulo: Ed. Ática, 19ª edição, 1998.

REVEL, J. Microanálise e construção do social. In: Jogos de escala. Rio de Janeiro: FGV, 1998, p. 15-38.

RIBEIRO JUNIOR, Jorge Cláudio Noel. A festa do povo: pedagogia de resistência. Petrópolis: Vozes, 1982.

ROCKWELL, E. Metáforas para encontrar histórias inesperadas. In: NEPOMUCENO, M. A. \& TIBALLI, E. A educação e seus sujeitos na história. Belo Horizonte: Argvmentvm, 2007, p. 15-33.

SANCHIS, Pierre. Arraial: festa de um povo - as romarias portuguesas. Lisboa: Publicações D. Quixote, 1983.

SANTOS, Vera Lúcia dos. A Revista do "Patrocínio": textos e imagens de um periódico escolar dedicado à formação feminina (décadas de 20 e 30, século XX). Dissertação de Mestrado. São Paulo: FEUSP, 2004.

SEED, Patrícia. Cerimônias de Posse na Conquista Européia do Novo Mundo (1492-1640). ESTEVES, Lenita R. (trad.). São Paulo: Ed. UNESP, 1999 (UNESP/Cambridge).

SEVCENKO, Nicolau. Literatura como missão: tensões sociais e criação cultural na Primeira República. São Paulo: Brasiliense, 1983, introdução e conclusão. 
SHAEFFNER, M. R; CÂNDIDO, R. M. Dualidade $e$ ambigüidade no debate educacional: um estudo dos discursos veiculados na Revista de Ensino de São Paulo (1902-1918). In: Anais da Semana de Educação da FEUSP. São Paulo, 2005, 01-10.

SCHEFFLER, Israel. A linguagem da educação. BARBOSA FILHO, Balthazar (trad.). São Paulo: Editora da Universidade de São Paulo, 1974.

SCHELBAUER, Analete Regina. O método intuitivo e lições de coisas no Brasil do século XIX. In: STEPHANOU, Maria e BASTOS, Maria Helena Câmara. Histórias e Memórias da Educação no Brasil, vol. II - século XIX. Petrópolis: Editora Vozes, 2005, p. 133- 149.

SCHRIEWER, J.; NÓVOA, A. A difusão mundial da escola. Lisboa: Educa, 2000.

SILVA, Celeida Maria Costa de Souza e. Festas escolares e cultura cívica em Mato Grosso do Sul (1977-1998). In: Anais do VI Congresso Luso-Brasileiro de História da Educação. Minas Gerais, p. 4091 - 4099.

SILVA, Katiene Nogueira da. Do controle das paixões à maestria de si: um estudo acerca das práticas e das representações de moralização na escola pública paulista (1948 - 1978). Tese de Doutorado. São Paulo: FEUSP, 2011.

SILVA, Milena Colazingari da. Conhecimento Pedagógico e escola: um exame a partir da Revista Brasileira de Estudos Pedagógicos (1950-1971). Dissertação de Mestrado defendida na Faculdade de Educação da Universidade de São Paulo. São Paulo, FEUSP, 2005.

SILVA, Vera Lúcia Gaspar da. Sentidos da profissão docente - Estudo comparado acerca de sentidos da profissão docente do ensino primário, envolvendo Santa Catarina, São Paulo e Portugal na virada do século XIX para o século XX. Tese de Doutorado. São Paulo: FEUSP, 2004, p. 01-29.

SILVA, V. B. ; CORREIA, António Carlos da Luz . Uma história de leituras para professores em Portugal e no Brasil (1930-1971). In: II Congresso Brasileiro de História da Educação, 2002, Natal - RN. Anais II Congresso Brasileiro de História da Educação - História e memória da educação brasileira. Natal : NAC, 2002. v. 1. P. 1-10.

SILVA, Vivian Batista. "Uma história das leituras para professores - análise da produção e circulação de saberes especializados nos manuais pedagógicos (19301971)". In: Revista Brasileira de História da Educação, no 6, jul./dez./ 2003, p. 2957. 
SILVA, Vivian Batista da. Saberes em viagem nos manuais pedagógicos: construções da escola em Portugal e no Brasil (1870-1970). Tese de Doutorado. São Paulo: FEUSP, 2006.

SONTAG, Susan. Sobre fotografia. São Paulo: Companhia das Letras, 2004.

SOUZA, Rosa Fátima de. Templos de Civilização: a Implantação dos Grupos Escolares no Estado de São Paulo (1890-1910). São Paulo: Fundação Editora da UNESP, 1998.

SOUZA, Rosa Fátima de. Rituais escolares: liturgia cívica e glorificação da memória (aproximações históricas). In: PORTO, SANCHEZ TEIXEIRA, FERREIRA SANTOS, BANDEIRA (orgs.). Tessituras do Imaginário: cultura \& educação. Cuiabá: Edunic/CICE/FEUSP, 2000, p. 173-184.

TARDIF, Maurice. Saberes docentes e formação profissional. Rio de Janeiro: Vozes, $12^{\mathrm{a}}$ edição, 2011.

TEIXEIRA, Almerinda Pinheiro Cardoso M. A Senhora do Castelo - gênese de uma festa na serra de Montemuro. In: Análise Social, vol. XIX (77-78-79), 1983-3. ${ }^{\circ}, 4 .^{\circ} 5 .^{\circ}$, 667-682.

TEIXEIRA, Inês Assunção de Castro. Cadências escolares, ritmos docentes. Educação e Pesquisa, São Paulo, v. 25, n. 2, jul - dez/1999, p. 87-108.

TOMÁS, Dinis. Escola em Festa (Poesias e dramatizações para festas escolares). Portugal - Província de Angola: Serviços de Educação/Inspeção Provincial de Educação, Imprensa Nacional de Angola, 1968.

VASCONCELOS, Faria de. Obras Completas (1915-1920). Vol. II. Lisboa: Fundação Calouste Gulbenkian, 2000.

VARELA, Julia \& ALVAREZ-URIA, Fernando. A Maquinaria Escolar. Teoria e educação, 6, 1992. p. $69-97$.

VAZ, Aline Choucair. Práticas escolares e festividades cívicas em Minas Gerais (19371945). In: Anais do VI Congresso Luso-Brasileiro de História da Educação. Minas Gerais, p. $4505-4517$.

VAZ, Léo. O professor Jeremias. São Paulo: Monteiro Lobato \& C. Editores, $4^{\mathrm{a}}$ edição, 1921. 
VEIGA, Cynthia Greive e GOUVEA, Maria Cristina S. Comemorar a infância, celebrar qual criança? Festejos comemorativos nas primeiras décadas republicanas. Educação e Pesquisa, São Paulo, v. 26, nº 1, jan - jun/2000, p.135-160.

VEIGA, Cynthia Greive. Educação estética para o povo. In: LOPES, Eliana Marta Teixeira; FARIA FILHO, Luciano Mendes; VEIGA, Cynthia Greive (orgs.). 500 anos de educação no Brasil. Belo Horizonte: Autêntica, 2000, p. 399-422.

VICENTINI, Paula Perin. Imagens e representações de professores na História da Profissão Docente no Brasil (1933-1963). Tese de doutorado. São Paulo: FEUSP, 2002.

VIDAL, Diana Gonçalves. A Imagem na Reforma Educacional Carioca da Década de 20: fotografia, cinema e arquitetura. Anais do Seminário "Pedagogia da imagem, imagem na Pedagogia". Niterói: Universidade Federal Fluminense/Faculdade de Educação/Departamento de Fundamentos Pedagógicos, 1996, p. 175-180.

VIDAL, Diana Gonçalves. A fotografia como fonte para a historiografia educacional sobre o século XIX: uma primeira aproximação. In: FARIA FILHO, Luciano M. de (org.). Educação, Modernidade e Civilização. Bahia: Autêntica, 1998, p. 75-87.

VIDAL, Diana Gonçalves. Culturas escolares - Estudo sobre práticas de leitura e escrita na escola pública primária (Brasil e França, final do século XIX). Campinas: Autores Associados, 2005.

VIDAL, Laurent. Alain Corbin o prazer do historiador. Rev. Bras. Hist., Jan 2005, vol.25, no.49, p.11-31.

VILlELA, Heloisa de Oliveira Santos. Da Palmatória à lanterna mágica: A Escola Normal na Província do Rio de Janeiro entre o artesanato e a formação profissional (1868-1876). Doutorado em Educação. São Paulo: FEUSP, 2002, p. 1-46; 209-224.

VINÃO FRAGO, Antonio. Culturas escolares, reformas e innovaciones: entre la tradición y el cambio. VIII Jornadas Estatales Fórum Europeo de Administradores de la educación. Murcia: 1996, p.17- 29.

VINCENT, Guy; LAHIRE, Bernard; THIN, Daniel. Sobre a história e a teoria da forma escolar. Educação em Revista, Belo Horizonte, no. 33, jun de 2001, p. 7 - 47.

VOVELLE, Michel. Ideologias e Mentalidades. São Paulo: Brasiliense, 2004. 
WEBER, Franz. Celebrar a vida: a cultura da festa nas Comunidades Eclesiais de Base (CEBs). In: PASSOS, Mauro. (org.) A festa na vida: significado e imagens. Rio de Janeiro: Petrópolis: Vozes, 2002, p. 143 - 164.

WOLFF, Antonio Pedro (org.). Festas escolares: coletâneas de poesias, monólogos, diálogos, hinos, etc, para as comemorações cívicas de todas as datas nacionais. Primeiro Volume: Tiradentes - 21 de abril. São Paulo: Typografia Excelsior, 1918.

XAVIER FILHA, Constatina. Discursos da intimidade: imprensa feminina e narrativas de mulheres professoras-brasileiras e portuguesas na segunda metade do século XX. São Paulo: FEUSP, 2004. 
Anexos 


\section{Anexos}

\section{Periódicos de Ensino Brasileiros}

1) A Eschola Publica,1893 -1897;

2) Revista de Ensino, 1902 - 1918;

3) Anuários do Ensino do Estado de São Paulo,1907 - 1926;

4) Revista Escolar, 1925 - 1927. 


\section{A Eschola Publica (1893-1897)}

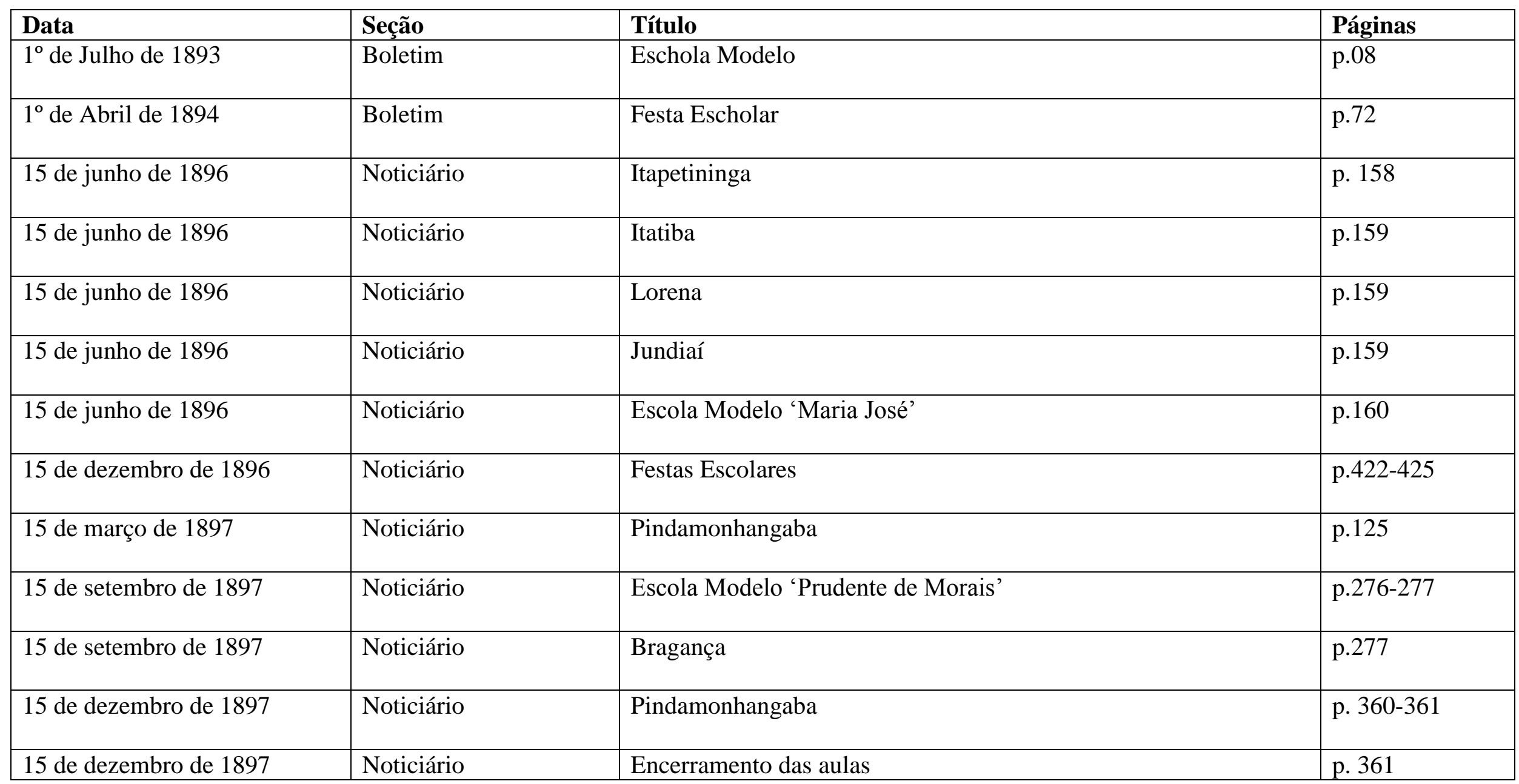


ReVista de ENSINO (1902-1918)

\begin{tabular}{|c|c|c|c|c|c|}
\hline Data & $\begin{array}{l}\text { Volume/ } \\
\text { Ano }\end{array}$ & Número & Seção & Título & Páginas \\
\hline $\begin{array}{l}\text { Agosto de } \\
1902\end{array}$ & I & 3 & $\begin{array}{l}\text { Pedagogia } \\
\text { Prática }\end{array}$ & 21 de Abril & p. $522-526$ \\
\hline $\begin{array}{l}\text { Agosto de } \\
1902\end{array}$ & I & 3 & Noticiário & Arbor-day & p.570-572 \\
\hline $\begin{array}{l}\text { Agosto de } \\
1902\end{array}$ & I & 3 & Noticiário & 2 de Agosto & p. 578 \\
\hline $\begin{array}{l}\text { Outubro de } \\
1902\end{array}$ & I & 4 & Noticiário & Grupo Escolar de Taubaté & p. $821-822$ \\
\hline $\begin{array}{l}\text { Dezembro de } \\
1902\end{array}$ & I & 5 & Noticiário & Garden Party & p.1015-1019 \\
\hline $\begin{array}{l}\text { Fevereiro de } \\
1903\end{array}$ & I & 6 & & $\begin{array}{l}\text { "Impressões de uma Festa Escolar", carta aberta ao Dr. } \\
\text { Mario Bulcão por Valentim Magalhães }\end{array}$ & p. $1051-1055$ \\
\hline Junho de 1903 & II & 2 & $\begin{array}{l}\text { Questões } \\
\text { Gerais }\end{array}$ & Festas das Árvores em Itapira & p.121-124 \\
\hline $\begin{array}{l}\text { Outubro de } \\
1903\end{array}$ & II & 4 & Diversos & 7 de Setembro (Festa Infantil) & p.395-397 \\
\hline Junho de 1904 & III & 2 & & O dia da Instrução & p. $159-162$ \\
\hline Junho de 1904 & III & 2 & & Escola Complementar de Guaratinguetá & p.162-170 \\
\hline Junho de 1904 & III & 2 & Noticiário & Grupo escolar do Rio Claro & p. 218 \\
\hline $\begin{array}{l}\text { Agosto de } \\
1904\end{array}$ & III & 3 & Noticiário & 2 de Agosto & p. 355 \\
\hline $\begin{array}{l}\text { Outubro de } \\
1904\end{array}$ & III & 4 & Diversos & $\begin{array}{l}\text { Carta aberta ao Sr. Diretor do Grupo Escolar de } \\
\text { Guaratinguetá" por J. L. Rodrigues }\end{array}$ & p. $384-387$ \\
\hline Junho de 1905 & IV & 2 & Diversos & $\begin{array}{l}\text { Discurso pronunciado pelo professor Arnaldo Barreto, } \\
\text { paranympho dos professorandos de } 1904 \text {, da escola }\end{array}$ & p.654-660 \\
\hline
\end{tabular}




\begin{tabular}{|c|c|c|c|c|c|}
\hline & & & & complementar "Caetano de Campos" & \\
\hline $\begin{array}{l}\text { Janeiro de } \\
1906\end{array}$ & IV & 4 & Noticiário & Garden Party & p.781 \\
\hline Julho de 1906 & $\mathrm{~V}$ & 1 & $\begin{array}{l}\text { Os nossos } \\
\text { edifícios escolares }\end{array}$ & "Grupo Escolar do Arouche" & p.31-33 \\
\hline $\begin{array}{l}\text { Setembro de } \\
1907\end{array}$ & VI & 4 & Noticiário & Grêmio Normalista '2 de Agosto' & p. 53-54 \\
\hline $\begin{array}{l}\text { Setembro de } \\
1907\end{array}$ & VI & 4 & Noticiário & Paul Doumer & p. 54 \\
\hline $\begin{array}{l}\text { Novembro de } \\
1907\end{array}$ & VI & 5 & & $\begin{array}{l}\text { "As comemorações cívicas e a educação moderna" } \\
\text { (simples observações aos meus alunos) por José } \\
\text { Feliciano }\end{array}$ & p. $85-87$ \\
\hline Março de 1908 & VII & 1 & Diversos & $\begin{array}{l}\text { Discurso pronunciado pelo inspetor das escolas anexas à } \\
\text { Escola Normal, professor Carlos A. Gomes Cardim, em } \\
\text { sessão solene de formatura dos professorandos } \\
\text { complementaristas de } 1907\end{array}$ & p.30-36 \\
\hline Março de 1908 & VII & 1 & Noticiário & O festival das escolas isoladas & p.49-50 \\
\hline $\begin{array}{l}\text { Dezembro de } \\
1908\end{array}$ & VII & 4 & Diversos & $\begin{array}{l}\text { Discurso pronunciado pelo Professor Carlos Alberto } \\
\text { Gomes Cardim, no ato de colação de grau às } \\
\text { professorandas normalistas de Vitória, no Estado do } \\
\text { Espírito Santo, onde se encontra a comissão }\end{array}$ & p.26-32 \\
\hline $\begin{array}{l}\text { Dezembro de } \\
1908\end{array}$ & VII & 4 & Diversos & Festas escolares & p.35-36 \\
\hline Junho de 1911 & $\mathrm{X}$ & 1 & & Escola Normal de Mato Grosso & p. $39-41$ \\
\hline Junho de 1911 & $\mathrm{X}$ & 1 & & $\begin{array}{l}\text { O presente número da Revista, é em grande parte } \\
\text { dedicado à publicação de trabalhos literários - inéditos } \\
\text { uns, já conhecidos outros - que constituem uma } \\
\text { coletânea para a Festa das Árvores, a efetuar-se em } \\
\text { Setembro...”(p.03). }\end{array}$ & \\
\hline Março de 1912 & $\mathrm{XI}$ & 1 & Variedades & Festa Cívica & p.127-136 \\
\hline
\end{tabular}




\begin{tabular}{|c|c|c|c|c|c|}
\hline Março de 1912 & $\mathrm{XI}$ & 1 & Notas & $\begin{array}{l}\text { "Instituto Profissional Feminino, a festa inaugural - o } \\
\text { que tem feito a escola desde a sua instalação" }\end{array}$ & p.145-148 \\
\hline Junho de 1913 & XII & 1 & $\begin{array}{l}\text { Em classe e } \\
\text { para classe }\end{array}$ & $\begin{array}{l}\text { Descobrimento do Brazil (Nota para uma comemoração } \\
\text { cívica)" por João L. Rodrigues }\end{array}$ & p.21-33 \\
\hline $\begin{array}{l}\text { Setembro de } \\
1913\end{array}$ & XII & 2 & $\begin{array}{l}\text { Literatura } \\
\text { Infantil }\end{array}$ & $\begin{array}{l}\text { "Hymno dos Estados" - Letra do professor Honório } \\
\text { Guimarães, cantada pelas alunas do Grupo Escolar que } \\
\text { o mesmo dirige em Araguary (Minas), no dia } 14 \text { de } \\
\text { Julho de } 1913 \text {, por ocasião dos festejos escolares ahi } \\
\text { realizados, inaugurando-se também nesse dia a banda } \\
\text { musical de alunos }\end{array}$ & p. 40 \\
\hline $\begin{array}{l}\text { Dezembro de } \\
1914\end{array}$ & XIII & 3 & & Escola Normal & p.16-24 \\
\hline Junho de 1915 & XIV & 1 & $\begin{array}{l}\text { Literatura } \\
\text { Infantil }\end{array}$ & Festa das Árvores por Francisco Alves Mourão & p. $40-46$ \\
\hline Março de 1916 & XIV & 4 & & A Festa da Bandeira & p.13-23 \\
\hline Junho de 1916 & $\mathrm{XV}$ & 1 & Divagações & Festa das Aves por João T. da Silva Braga & p.37-38 \\
\hline $\begin{array}{l}\text { Setembro de } \\
1916\end{array}$ & $\mathrm{XV}$ & 2 & & $\begin{array}{l}\text { Festa de "Sete de Setembro", comédia em um ato por } \\
\text { Oscar Guilherme }\end{array}$ & p. $40-46$ \\
\hline $\begin{array}{l}\text { Setembro de } \\
1916\end{array}$ & $\mathrm{XV}$ & 2 & Notas & Escola Normal Primária de Botucatu & p. 48 \\
\hline $\begin{array}{l}\text { Dezembro de } \\
1917 \text { e Março } \\
\text { de } 1918\end{array}$ & XVII & 3 e 4 & Literatura & Olavo Bilac & p.67-76 \\
\hline
\end{tabular}




\section{Anuários de Ensino do Estado de São Paulo (1907-1926)}

\begin{tabular}{|c|c|c|}
\hline Data & Título & Páginas \\
\hline $\begin{array}{l}1907- \\
1908\end{array}$ & $\begin{array}{l}\text { Relatório apresentado ao Exmo. Snr. Secretario dos Negócios do Interior pelo Professor João } \\
\text { Lourenço Rodrigues, inspetor geral do ensino. }\end{array}$ & p. 63-66 \\
\hline $\begin{array}{l}1908- \\
1909\end{array}$ & Relatório do Inspetor Escolar Aristides de Macedo & p. 20-24 \\
\hline $\begin{array}{l}1908- \\
1909\end{array}$ & Relatório do Inspetor Miguel Carneiro Junior & p. 57-72 \\
\hline $\begin{array}{l}1910- \\
1911\end{array}$ & $\begin{array}{l}\text { Relatório apresentado pelos Inspetores Escolares ao Exmo. Snr. Dr. Secretário do Interior em } 1911 . \\
\text { Do Inspetor Escolar Theodoro de Morais }\end{array}$ & p. 13-38 \\
\hline $\begin{array}{l}1910- \\
1911\end{array}$ & $\begin{array}{l}\text { Relatório do Inspetor Escolar José Monteiro Boanova - Festas escolares consagradas às árvores e aos } \\
\text { pássaros }\end{array}$ & p. 53-54 \\
\hline 1917 & $\begin{array}{l}\text { Relatório apresentado ao Exmo. Snr. Dr. Secretário do Interior por Oscar Thompson - Diretor Geral } \\
\text { da Instrução Pública - Do ensino cívico }\end{array}$ & p.73-128 \\
\hline 1918 & $\begin{array}{l}\text { Relatório apresentado ao Exmo. Snr. Dr. Secretário do Interior por Oscar Thompson - Diretor Geral } \\
\text { da Instrução Pública" - "Festas Escolares" por J. T. D. Sadler (Diretor do Ginásio Anglo-Brasileiro) }\end{array}$ & p.113-114 \\
\hline 1919 & Lei $^{\circ} 1710$ de 27 de dezembro de 1919 - Dispõe sobre a organização e a fiscalização do ensino & p.183-188 \\
\hline 1919 & $\begin{array}{l}\text { Decreto } \mathrm{n}^{\circ} 3205 \text { de } 29 \text { de abril de } 1920 \text { - Regulamento para execução da Lei no } 1710 \text { de } 27 \text { de } \\
\text { Dezembro de } 1919 \text {, que dispõe sobre a organização do ensino }\end{array}$ & p.195-209 \\
\hline
\end{tabular}




\begin{tabular}{|l|l|l|}
\hline 1922 & As delegacias regionais foram enviadas, durante o ano de 1922, as seguintes circulares (...) & p.105-112 \\
\hline 1922 & Sr. Delgado Regional ... & p.112 \\
\hline 1922 & Festa do centenário & p.301-302 \\
\hline 1922 & Ás delegacias regionais foi expedia a seguinte circular & p.303 \\
\hline 1922 & As datas de 15 e 19 de Novembro, no ano do centenário & p.353-354 \\
\hline
\end{tabular}




\section{REVISTA ESCOLAR (1925-1927)}

\begin{tabular}{|c|c|c|c|c|}
\hline Data & Número & Seção & Título & Páginas \\
\hline $\begin{array}{l}\text { Fevereiro de } \\
1925\end{array}$ & 2 & Pelas Escolas & Festas Escolares por J. V & p. $104-106$ \\
\hline Outubro de 1925 & 10 & & "Educação Cívica" - O Pavilhão Nacional" & p. $28-31$ \\
\hline Outubro de 1925 & 10 & Notícias & 7 de Setembro & p. $102-105$ \\
\hline Outubro de 1925 & 10 & Notícias & Festa das Árvores & p.106 \\
\hline $\begin{array}{l}\text { Dezembro de } \\
1925\end{array}$ & 12 & Notícias & 15 de Novembro & p.101 \\
\hline $\begin{array}{l}\text { Dezembro de } \\
1925\end{array}$ & 12 & Notícias & Festa da Bandeira & p.103 \\
\hline $\begin{array}{l}\text { Fevereiro de } \\
1926\end{array}$ & 14 & Literatura & Festa da Bandeira por Euclydes Luz & p.76-79 \\
\hline Março de 1926 & 15 & $\begin{array}{l}\text { Literatura } \\
\text { Infantil } \\
\end{array}$ & A festa das aves por Ernestino Lopes & p. $79-85$ \\
\hline Maio de 1926 & 17 & $\begin{array}{l}\text { Questões } \\
\text { Gerais }\end{array}$ & Festas Escolares-Passeios por Evilasio A. de Souza & p. 47-50 \\
\hline Setembro de & 21 & Notícias & Orpheão Infantil & p.86 \\
\hline
\end{tabular}




\begin{tabular}{|c|c|c|c|c|}
\hline 1926 & & & & \\
\hline Outubro de 1926 & 22 & $\begin{array}{l}\text { Literatura } \\
\text { Infantil }\end{array}$ & O dia da criança (cena escolar) & p.54-56 \\
\hline Outubro de 1926 & 22 & $\begin{array}{l}\text { Literatura } \\
\text { Infantil }\end{array}$ & $\begin{array}{l}\text { "A criança" (cena escolar para o Dia da Criança) por Honorato } \\
\text { Faustino }\end{array}$ & p.66-68 \\
\hline Outubro de 1926 & 22 & Notícias & 7 de Setembro & p.82 \\
\hline $\begin{array}{l}\text { Dezembro de } \\
1926\end{array}$ & 24 & Notícias & A Festa da Bandeira & p.75-76 \\
\hline $\begin{array}{l}\text { Dezembro de } \\
1926\end{array}$ & 24 & Notícias & O Dia da Música & p.76 \\
\hline $\begin{array}{l}\text { Fevereiro de } \\
1927\end{array}$ & 26 & $\begin{array}{l}\text { Literatura } \\
\text { Infantil }\end{array}$ & Conceito Infantil por Ephigenia C. Teixeira & p.62-63 \\
\hline Junho de 1927 & 30 & $\begin{array}{l}\text { Literatura } \\
\text { Infantil }\end{array}$ & Uma festa escolar por Medeiros e Albuquerque & p.47-48 \\
\hline Julho de 1927 & 31 & $\begin{array}{l}\text { Literatura } \\
\text { Infantil }\end{array}$ & "O 7 de setembro" por Joaquim A. Ladeira & p.51-54 \\
\hline
\end{tabular}




\section{Anexos}

Periódicos de Ensino Portugueses

1) A escola: Revista de Pedagogia e de Instrução Pública, 1890.

2) Revista Infantil, 1911 com interrupções até 1928.

3) O Magistério, 1914-1916.

4) Revista Escolar Portuguesa, 1921-1935.

5) A Escola Primária, 1927 - 1934. 


\section{A escola: Revista de Pedagogia e de Instrução Pública (1890).}

\begin{tabular}{|l|l|l|l|}
\hline Ano & Mês & Volume/Número & Título \\
\hline 1890 & 29 de maio & No 134/ $5^{\text {a }}$ série & Exposição escolar no Palácio de Cristal, s. p \\
\hline 1890 & 14 de agosto & No 142/ $6^{\text {a } \text { série }}$ & Exposições pedagógicas em Portugal - II, s.p. \\
\hline 1890 & 21 de agosto & No $143 / 6^{\text {a }}$ série & Nas Pedras Salgadas - Festa escolar (extraído do Correio da Manhã), s.p. \\
& & Festa escolar em Rio Maior - Cópia do relatório, s.p. \\
\hline 1890 & 16 de outubro & No. 151/ $6^{\text {a } \text { série }}$ & Grandes festejos em Roma, s.p. \\
\hline
\end{tabular}


REVISTA INFANTIL (1912 - 1927)

\begin{tabular}{|c|c|c|c|}
\hline Ano & Mês & Volume/Número & Título \\
\hline 1912 & 1 de janeiro & n. 3/anno I & A Festa da Árvore, p. 12 \\
\hline 1912 & 15 de maio & n. 12/ anno I & $\begin{array}{l}\text { "Uma bela festa, p. } 47 \\
\text { "Discurso proferido pelo presidente da Comissão da Festa da Árvore em Portel (Leonardo Moraes, de } \\
12 \text { anos), p. } 48 .\end{array}$ \\
\hline 1912 & 1 junho & $\begin{array}{l}\text { n. 13/ ano I } \\
\text { Outro número } \\
\text { continuação da } \\
\text { mesma notícia } \\
\text { sobre as festas! }\end{array}$ & $\begin{array}{l}\text { "A festa da árvore em Portel - Discurso proferido pelo aluno José Pombinho, de } 13 \text { anos, vice- } \\
\text { presidente da Comissão Promotora, p. } 52 .\end{array}$ \\
\hline 1921 & $\begin{array}{l}25 \text { de } \\
\text { dezembro }\end{array}$ & n. 37/ ano V & A festa do Natal - $\mathrm{O}$ nosso $6^{\circ}$ aniversário, p. 153. \\
\hline 1922 & 15 de abril & n. 41/ ano VI & Noticiário - Caixa Infantil, p. 191 \\
\hline 1923 & 15 de junho & n. 53/ ano VII & Associação Infantil, p. 286-287. \\
\hline 1923 & $\begin{array}{l}15 \mathrm{de} \\
\text { outubro }\end{array}$ & n. 54/ ano VII & Discursos - festa de encerramento do ano, s.p \\
\hline
\end{tabular}




\begin{tabular}{|l|l|l|l|}
\hline 1923 & $\begin{array}{l}15 \text { de } \\
\text { novembro }\end{array}$ & n. 55/ ano VII & Festa simpática, p. 303 \\
\hline 1924 & $\begin{array}{l}8 \text { de } \\
\text { fevereiro }\end{array}$ & n. 58/ ano VIII & Noticiário, p. 323 \\
\hline 1924 & 15 de maio & n. 61/ ano VIII & Noticiário - Caixa Escolar, p. 352. \\
\hline 1924 & $\begin{array}{l}15 \text { de } \\
\text { novembro }\end{array}$ & n. 64/ ano VIII & $\begin{array}{l}\text { Noticiário - Sessão Solene, p. 371 } \\
\text { Festa da Ave, p. 371. }\end{array}$ \\
\hline 1925 & $\begin{array}{l}15 \text { de } \\
\text { fevereiro }\end{array}$ & n. 67/ ano IX & Noticiário - Caixa Escolar, p. 400 \\
\hline 1927 & \begin{tabular}{l}
1 de janeiro \\
\hline
\end{tabular} & n. 73/ ano X & Ligas da bondade, s.p \\
\hline
\end{tabular}




\section{O MAgiSTÉRIO (1914-1916)}

\begin{tabular}{|l|l|l|l|}
\hline Ano & Mês & Volume/ Número & Título \\
\hline 1914 & 14 de junho & No. 11 & Os Normalistas de Lisboa, p. 3. \\
\hline 1914 & 21 de junho & n. 12/ ano 1 & Os Normalistas de Lisboa (conclusão), p. 3 \\
\hline 1914 & 12 de julho & n. 15/ ano 1 & Festa na Escola Académica, p. 02 \\
\hline 1914 & 19 de julho & n. 16/ ano 1 & Festa escolar, p. 03. \\
\hline 1914 & $\begin{array}{l}30 \text { de } \\
\text { agosto }\end{array}$ & n. 22/ ano 1 & A festa das aves, p. 02 \\
\hline 1914 & $\begin{array}{l}11 \text { de } \\
\text { outubro }\end{array}$ & n. 27 / ano 1 & Festa dos passarinhos, p. 01 \\
\hline 1915 & $\begin{array}{l}11 \text { de março } \\
\text { n.47 / ano 1 }\end{array}$ & Festa da árvore, p. 03 \\
\hline 1915 & 18 de março & n.48/ ano 1 & A Festa da Árvore e as Juntas de Paróquia do Porto, p. 2 \\
\hline 1915 & 1 de abril & n. 50 / ano 1 & Festa da Árvore, p. 02 \\
\hline
\end{tabular}




\section{REVISTA ESCOLAR (1922 - 1935).}

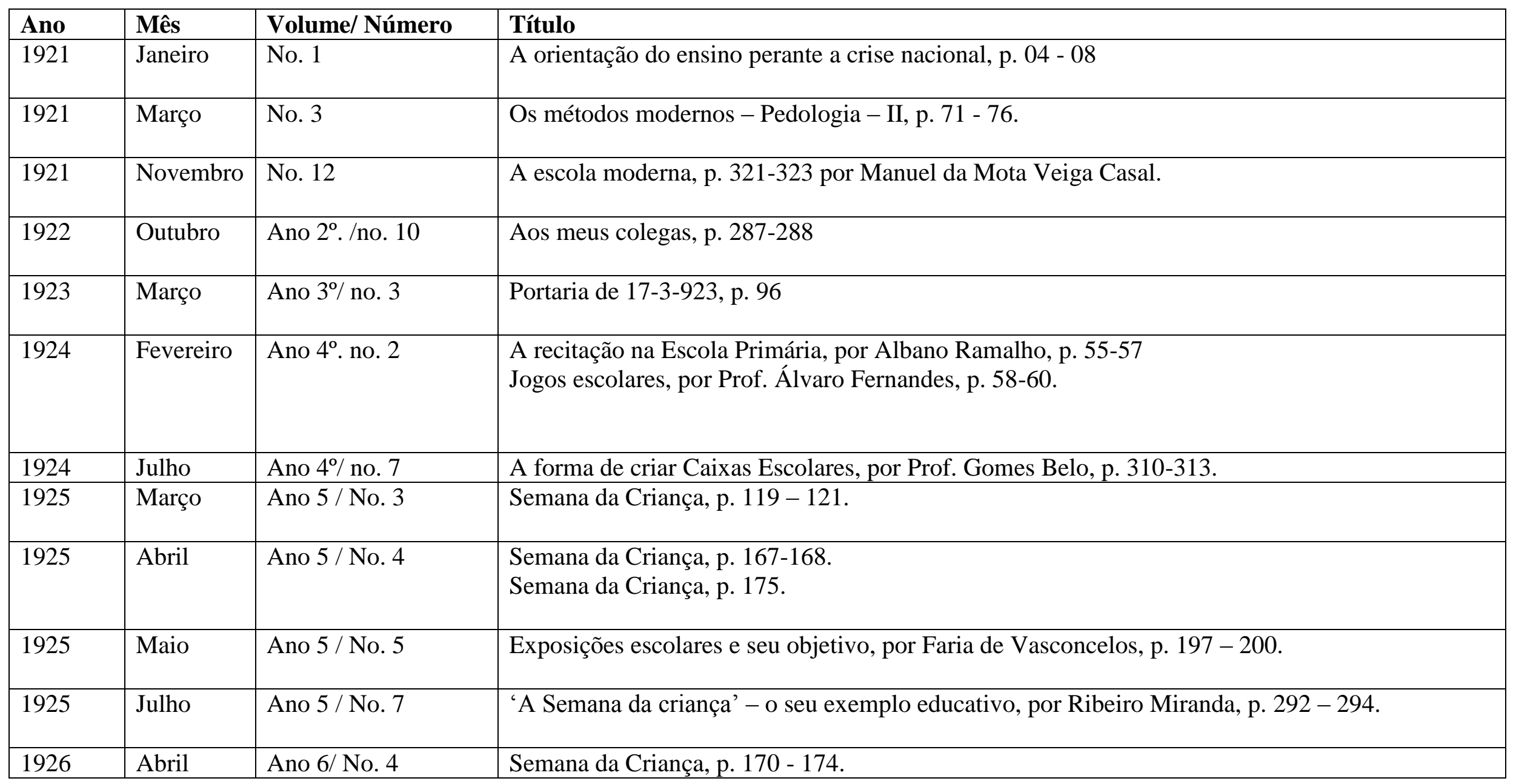




\begin{tabular}{|l|l|l|l|}
\hline & & & \\
\hline 1929 & Abril & Ano IX/ No. 4 & O Credo de José Guisti, por Vidal Oudinot, p. 228-230. \\
\hline 1930 & Fevereiro & Ano X/ No. 2 & Projeto dos Estatutos da Caixa Escolar, por Manuel Antunes Amor, p. 113 - 117. \\
\hline 1930 & Dezembro & Ano X/ No. 10 & Exposições Escolares, por Vidal Oudinot, p. 566 -569. \\
\hline 1934 & Março & Ano XIV/ No. 3 & A metodologia da educação cívica, por François Bassleer, p. 113 -118. \\
\hline
\end{tabular}




\section{A Escola Primária (1927 - 1930)}

\begin{tabular}{|c|c|c|c|}
\hline Ano & Mês & Volume/Número & Título \\
\hline 1927 & 22 de dezembro & n. $7 /$ ano 1 & A Página da Professora, Natal, p. 04 \\
\hline 1928 & 26 de janeiro & n. $12 /$ ano 1 & Homenagens lindas, p. $01-02)$. \\
\hline 1928 & 02 de fevereiro & n. $13 /$ ano 1 & Notícias e comentários, p. 04. \\
\hline 1928 & 23 de fevereiro & n. $16 /$ ano 1 & Notícias e comentários, p. 02 \\
\hline 1928 & 12 de abril & n. $23 /$ ano 1 & Notícias e Comentários - Semana da Criança, p. 02. \\
\hline 1928 & 20 de dezembro & n. 59/ ano II & Férias do Natal, p. 67. \\
\hline 1929 & 19 de janeiro & n. $62 /$ ano II & $\begin{array}{l}\text { Notícia e comentários, p. } 100 . \\
\text { Em Vila do Conde, homenagem, p. 104). }\end{array}$ \\
\hline 1929 & 17 de janeiro & n. 63/ ano II ( $2^{\mathrm{a}}$ série $)$ & Alfredo Soares, p. 113 \\
\hline 1929 & 21 de fevereiro & n., 68 & Récitas em benefício de Escolas, p. 165 \\
\hline 1929 & 30 de maio & n. $82 /$ ano II ( $2^{\mathrm{a}}$ série $)$ & $\begin{array}{l}\text { Festa escolar em Alenquer, p. } 302 \\
\text { Festa da Primavera em Alcáçovas, p. } 304 .\end{array}$ \\
\hline 1929 & 06 de junho & n. 83/ ano II ( $2^{\mathrm{a}}$ série $)$ & Escola 16 - Inauguração da Cantina Escolar, p. 313 \\
\hline 1929 & 20 de junho & n. $85 /$ ano II $\left(2^{\mathrm{a}}\right.$ série $)$ & Cantinas Escolares - Escolas 15 e 71, p. 331. \\
\hline 1929 & 04 de julho & n. 87/ ano II ( $2^{\mathrm{a}}$ série $)$ & Notícias e comentários - Semana da Criança, p. 346. \\
\hline
\end{tabular}




\begin{tabular}{|c|c|c|c|}
\hline 1929 & 11 de julho & n. $88 /$ ano II $2^{\mathrm{a}}$ série & $\begin{array}{l}\text { Coluna de crítica pelo Professor Eduardo Augusto da Silva, p. } 360 . \\
\text { Escola de Algés, p. } 361 .\end{array}$ \\
\hline 1929 & 25 de julho & Ano II/ 2a série/ no. 90 & Escola Oficial de Ameixoeira, p. 368. \\
\hline 1929 & 08 de agosto & Ano II/ $2^{\mathrm{a}}$ série/ no. 92 & Em Tomar na Venda Nova, p. 377 \\
\hline 1929 & 31 de outubro & $\begin{array}{l}\text { Ano II/ } 2^{\mathrm{a}} \text { série/ no. } \\
104\end{array}$ & \begin{tabular}{|l} 
Notícias e Comentários, p. 460. \\
Em Tomar - Na freguesia da Bezelga - Inauguração dum edifício escolar, p. 462.
\end{tabular} \\
\hline 1929 & 28 de novembro & $\begin{array}{l}\text { Ano III/ } 2^{\mathrm{a}} \text { série/ no. } \\
106\end{array}$ & Notícias e Comentários - Circular, p. 492. \\
\hline 1929 & 19 de dezembro & $\begin{array}{l}\text { Ano III/ } 2^{\text {a }} \text { série/ no. } \\
109\end{array}$ & $\begin{array}{l}\text { Pelos Ministérios, p. } 199 \\
\text { Repartição Pedagógica, p. } 201 \\
\end{array}$ \\
\hline 1930 & 20 de fevereiro & $\begin{array}{l}\text { Ano III/ 3 } 3^{\mathrm{a}} \text { série/ no. } \\
113\end{array}$ & Festa escolar, por Oliveira Charrua (Professor), p. 49. \\
\hline 1930 & 27 de março & $\begin{array}{l}\text { Ano III/ } 3^{\mathrm{a}} \text { série/ no. } \\
116\end{array}$ & Ao de leve, por Gil de Oliveira Mendonça, p. 101 - 102. \\
\hline 1930 & 10 de abril & $\begin{array}{l}\text { Ano III/ } 3^{\text {a }} \text { série/ no. } \\
117\end{array}$ & "Notícias e comentários - homenagem, p. 123-124 \\
\hline 1930 & 05 de julho & $\begin{array}{l}\text { Ano III/ } 3^{\mathrm{a}} \text { série/ no. } \\
122\end{array}$ & Notícias e comentários, p. 170-173. \\
\hline 1932 & 20 de abril & Ano IV-4 ${ }^{\mathrm{a}}$ série/ no. 2 & Comunicações, Festa escolar, p. 28 \\
\hline 1932 & 5 de maio & Ano IV-4a série/ no. 3 & Dia da Boa Vontade - 18 de maio, p. 39 \\
\hline 1932 & 20 de maio & Ano IV-4a série/ no. 4 & O Dia da Boa Vontade, p. 61 \\
\hline 1932 & 5 de junho & Ano IV-4a série/ no. 5 & Comunicações - Homenagem ao professor António Rodrigues Pena, p. 77. \\
\hline 1932 & 5 de julho & Ano IV-4a série/ no. 7 & Um apontamento sobre os prêmios escolares, por Cardoso Junior, p. 101 \\
\hline
\end{tabular}




\begin{tabular}{|l|l|l|l|}
\hline & & & \\
\hline 1933 & 05 de janeiro & $\begin{array}{l}\text { Ano IV-4 } 4^{\text {a }} \text { série/ no. } \\
15\end{array}$ & Escola Central no. 1, p. 236. \\
\hline 1933 & 20 de janeiro & $\begin{array}{l}\text { Ano IV-4 } 4^{\text {a }} \text { série/ no. } \\
16\end{array}$ & Uma festa educativa, p. 252. \\
\hline 1933 & 20 de maio & $\begin{array}{l}\text { Ano V }- \text { II série/ no. } \\
24\end{array}$ & O Dia da Boa Vontade por Cruz Filipe, p. 57. \\
\hline
\end{tabular}

